\title{
Interaction of dietary protein with energy balance
}

Citation for published version (APA):

Martens, E. A. P. (2014). Interaction of dietary protein with energy balance. [Doctoral Thesis, Maastricht University]. Maastricht University. https://doi.org/10.26481/dis.20141211em

Document status and date:

Published: 01/01/2014

DOI:

10.26481/dis.20141211em

Document Version:

Publisher's PDF, also known as Version of record

\section{Please check the document version of this publication:}

- A submitted manuscript is the version of the article upon submission and before peer-review. There can be important differences between the submitted version and the official published version of record.

People interested in the research are advised to contact the author for the final version of the publication, or visit the DOI to the publisher's website.

- The final author version and the galley proof are versions of the publication after peer review.

- The final published version features the final layout of the paper including the volume, issue and page numbers.

Link to publication

\footnotetext{
General rights rights.

- You may freely distribute the URL identifying the publication in the public portal. please follow below link for the End User Agreement:

www.umlib.nl/taverne-license

Take down policy

If you believe that this document breaches copyright please contact us at:

repository@maastrichtuniversity.nl

providing details and we will investigate your claim.
}

Copyright and moral rights for the publications made accessible in the public portal are retained by the authors and/or other copyright owners and it is a condition of accessing publications that users recognise and abide by the legal requirements associated with these

- Users may download and print one copy of any publication from the public portal for the purpose of private study or research.

- You may not further distribute the material or use it for any profit-making activity or commercial gain

If the publication is distributed under the terms of Article $25 \mathrm{fa}$ of the Dutch Copyright Act, indicated by the "Taverne" license above, 
Interaction of dietary protein with energy balance 


\section{itution}

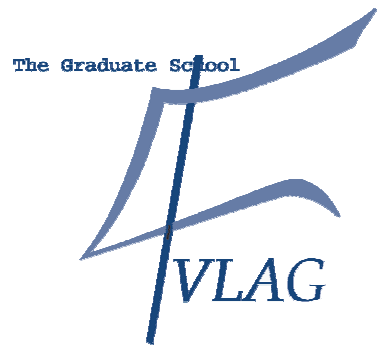

The work presented in this thesis was performed within NUTRIM, School for Nutrition, Toxicology and Metabolism, which participates in the Graduate School VLAG (Food Technology, Agrobiotechnology, Nutrition and Health Sciences), accredited by the Royal Netherlands Academy of Arts and Sciences.

The research described in this thesis has received funding from the European Union's Seventh Framework Programme for research, technological development and demonstration under grant agreement $n^{\circ}$ 266408. The studies described in the chapters 4 and 5 were funded by The Beef Checkoff. Food products for the studies described in this thesis were provided by Kellogg Company (chapters 3-4 and 7-9), and Solae, LLC (chapters 3 and 5).

\section{Yhellogis}

Financial support by Kellogg Company for the publication of this thesis is gratefully acknowledged.

Cover design: Remko Rinia

Layout: Tiny Wouters

Printed by: Gildeprint

(C) Copyright Eveline Martens, Maastricht 2014

ISBN 9789461088161 


\title{
Interaction of dietary protein with energy balance
}

\author{
PROEFSCHRIFT \\ Ter verkrijging van de graad van doctor \\ aan de Universiteit Maastricht, \\ op gezag van de Rector Magnificus, \\ Prof. dr. L.L.G. Soete \\ volgens het besluit van het college van Decanen, \\ in het openbaar te verdedigen \\ op donderdag 11 december 2014 om 12:00 uur.
}

door

Eveline Antonia Petronella Martens 


\section{Promotoren}

Prof. dr. M.S. Westerterp-Plantenga

Prof. dr. R.D. Mattes (Purdue University, United States)

\section{Beoordelingscommissie}

Prof. dr. R.P. Mensink, voorzitter

Prof. dr. J.G. Mercer (University of Aberdeen, United Kingdom)

Prof. dr. J. Plat

Prof. dr. A.B. Raben (University of Copenhagen, Denmark)

Prof. dr. K.R. Westerterp 


\section{Contents}

$\begin{array}{lll}\text { Chapter } 1 & \text { General introduction } & 7\end{array}$

Chapter $2 \quad$ Protein diets, body weight loss and weight maintenance 21

Chapter 3 Protein leverage affects energy intake of high-protein diets 33 in humans

Chapter $4 \quad$ Protein leverage effects of beef protein on energy intake in humans 51

Chapter $5 \quad$ No protein intake compensation for insufficient indispensable $\quad 71$ amino acid intake with a low-protein diet for 12 days

Chapter 6 Postprandial changes in appetite relate to postprandial changes in amino acid, GLP-1, ghrelin, and insulin concentrations after casein-, soy-, and whey-protein breakfasts

Chapter 7 Maintenance of energy expenditure on high-protein vs. highcarbohydrate diets at a constant body weight may prevent a positive energy balance

Chapter 8 The potential of a high protein-low carbohydrate diet to preserve intrahepatic triglyceride content in healthy humans

Chapter 9 Prolonged adaptation to a low-protein diet does not lead to a more negative whole-body protein balance when compared with a high-protein diet

Chapter 10 General discussion

Summary

Samenvatting

Valorisation

Dankwoord

List of publications 



\section{CHAPTER 1}

General introduction 
The prevalence of obesity and its associated health problems, such as type 2 diabetes and cardiovascular diseases, has increased to epidemic proportions in a growing number of countries $(1,2)$. Chronic positive energy balance, that is, energy intake exceeding energy expenditure, is the underlying mechanism. In situations of positive energy balance, excess energy obtained from food is stored in body reserves, subsequently resulting in body weight gain (3). The treatment of obesity implies loss of body weight, which requires a negative energy balance. At a negative energy balance, energy is mobilized from body reserves (3). The most efficient and effective way to achieve a negative energy balance is by applying an energy-restriction diet (4). However, suddenly decreasing energy intake from the habitual diet results in increased feelings of hunger and desire to eat, and in a decrease of the feeling of fullness. These changes in appetite make it hard to sustain a lower energy intake. Furthermore, body weight loss usually results in a reduction in energy expenditure due to loss of fat-free mass (FFM). These conditions counteract the negative energy balance induced by the energyrestricted diet, and create a situation in which it is difficult to loose body weight.

\section{PROTEIN INTAKE AND ENERGY BALANCE}

High-protein diets have come into focus as being beneficial strategies for body weight loss and weight maintenance thereafter (5-7). These diets have the potential to maintain a negative energy balance by sustaining satiety at the level of the original diet $(8,9)$, and sustaining energy expenditure, which is underscored by preservation of fat-free mass $(10,11)$. Most remarkable effects are shown when relatively high-protein diets are consumed in negative energy balance achieved by restriction of carbohydrate and fat intake, but not of protein intake.

The translation of high-protein diets as a treatment strategy into a preventive measure cannot be taken for granted because high-protein diets have different effects in relation to energy balance. A positive energy balance induced by overfeeding with a high-protein diet results in significant body weight gain. In a situation with low physical activity, fat mass as well as FFM were increased (12). Resistance training combined with a high-protein diet in positive energy balance enhanced FFM accretion (13).

Epidemiological studies suggest that protein intake is neither associated with body weight gain or obesity, nor with body weight loss (14). Furthermore, it has been observed that protein intake is maintained within a small range across populations and over time (15). Therefore, the question remains whether highprotein diets can prevent the development of a positive energy balance. Suitable dietary interventions would target both sides of energy balance through prevention of overeating as well as of decreases in energy expenditure. 
Short-term intervention studies using energy-balanced diets have already shown that high-protein diets induce a larger increase in satiety compared with diets lower in protein $(9,16-21)$. Furthermore, higher rates of energy expenditure $(22,23)$ and an initial negative energy balance $(22)$ were observed in response to energy-balanced high-protein diets. However, it is unclear whether the observed effects from these acute studies are transient or sustained, thus preventing body weight gain.

\section{Energy intake}

Energy intake represents the sum of energy obtained from the consumption of protein, carbohydrate, fat and alcohol. In general, energy intake is tuned to energy requirement and therefore to energy expenditure. This regulation occurs on a weekly, rather than on a daily basis (24). The dietary reference intake for protein covers $10-15 \%$ of the energy requirement (25). The current recommendation for fat is not to exceed an intake of $30-35 \%$ of energy (26). In a usual diet, carbohydrate provides the remaining $50-60 \%$ of energy.

Relatively high-protein diets enable the consumption of protein at the level of requirement, which is $0.83 \mathrm{~g} / \mathrm{kg}$ body weight/d for adults (27), while restricting energy intake. At a negative energy balance, consuming protein at the level of requirement appears to be sufficient to induce body weight loss while preserving FFM (11). Sustaining the original protein intake while decreasing carbohydrate and fat intake has prompted the 'protein leverage hypothesis' (Figure 1.1). This hypothesis encompasses a geometric model suggesting that protein intake depends on an individual-specific protein target intake $(29,30)$. This protein target intake adjusts the intake of carbohydrate and fat depending on the relative protein content of the diet. As a result, relatively high-protein diets would spontaneously induce an energy deficit, while lower-protein diets may result in overeating. Possible mechanisms for an inverse relation between dietary protein intake and energy intake may be increased or decreased satiation on high- and low-protein diets, respectively $(4,17)$. Furthermore, there may be a drive to adjust energy intake to meet protein or amino acid requirements.

\section{Protein-induced satiation}

Protein is reportedly the most satiating macronutrient on a calorie for calorie basis (31). Therefore, protein-induced satiation has been proposed as the main mechanism behind the beneficial effects of high-protein diets for body weight management. Dietary amino acids may affect satiety signaling in the brain directly via elevated blood concentrations (21,32-36). There are amino acid sensitive neurons in the brain stem and in the arcuate nucleus of the hypothalamus (32). The 'aminostatic theory' suggests that elevated serum amino acid concentrations, which cannot be channeled into protein synthesis, serve as satiety signaling 
molecules, and thereby suppress food intake (37). Dietary amino acids may also have indirect effects on satiety signaling. Amino acid sensors have been detected in the duodeno-intestinal and hepatoportal regions (38). Depending on the type of amino acid, they increase or decrease the activity of hepatic vagal afferent fibers, subsequently promoting satiety signaling in the brain (38). Furthermore, plasma concentrations of gut hormones such as glucagon-like peptide 1 (GLP-1) and ghrelin change in response to the peripheral and central detection of amino acids (39). GLP-1 is released from the endocrine L-cells of the gastrointestinal tract in response to food intake in proportion to energy intake and in relation to macronutrient composition $(39,40)$. Increased concentrations of GLP-1 have been shown to reduce appetite (40). Also, changes in plasma glucose concentrations may be involved in food intake regulation $(39,41)$. Postprandial increases in glucose concentrations trigger insulin secretion by the $\beta$-cells of the pancreatic islets, which induces appetite-suppressive effects $(41,42)$. Ghrelin is secreted primarily by the gastric X-cells during fasting (39). Ghrelin concentrations lagged behind changes in hunger scores and insulin concentrations (43), suggesting a role for insulin as negative regulator of ghrelin (44).

Moreover, high protein-low carbohydrate diets may contribute to the development of a ketogenic state through the formation of ketone bodies. After deamination by the liver, amino acids with ketogenic properties may be converted into the ketone bodies acetoacetic acid and $\beta$-hydroxybutyric acid, and into minute quantities of acetone (45). It has previously been shown that $\beta$-hydroxybutyrate concentrations increased in parallel to the appetite suppressive effects of ketogenic high-protein diets $(46,47)$.

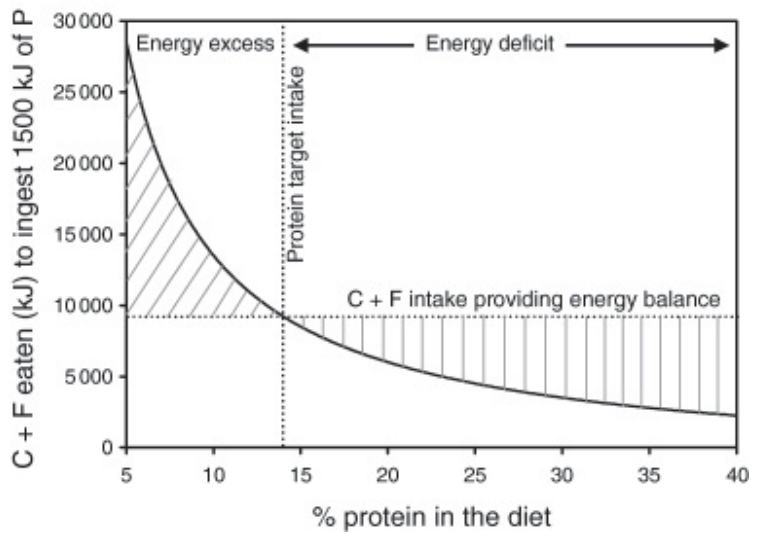

Figure 1.1 The protein leverage hypothesis (28). 


\section{Protein and indispensable amino acid requirements}

Meeting metabolic needs for amino acids is crucial to ensure health (25). Amino acids provide nitrogen and carbon skeletons for tissue protein synthesis and for the production of nitrogenous compounds involved in a range of bodily functions (48). All types of amino acids are needed physiologically but some cannot be synthesized in the body and must therefore be obtained through the diet, the dietary indispensable amino acids (IAA). Protein quality evaluation aims to determine the capacity of food sources and diets to meet protein and IAA requirements. Currently, nitrogen balance studies are primarily applied to define protein requirements as the degree to which protein intake compensates for obligatory loss of nitrogen from several pathways including amino acid breakdown $(25,49)$. According to the World Health Organization, adults require a protein intake of at least $0.66 \mathrm{~g} / \mathrm{kg}$ body weight/d to maintain nitrogen balance. Protein source may influence nitrogen balance, because diets containing protein of lower quality may be associated with increased loss of nitrogen $(48,50,51)$. The digestible IAA score (DIAAS) is a way to define protein quality by the extent to which dietary IAA are provided in proportion to requirements (25). The DIAAS would enable determination of whether protein intake from a certain diet is sufficient to satisfy the metabolic needs for individual IAA.

\section{Energy expenditure}

Protein, carbohydrate, fat and alcohol obtained from food are utilized for energy expenditure in a hierarchical order. Since energy absorbed from alcohol cannot be stored in the body, alcohol is the first macronutrient that is oxidized. The energy released from the oxidation of alcohol is about $28 \mathrm{~kJ} / \mathrm{g}$. Amino acids that are consumed in excess are oxidized, or converted to glycogen or fat and stored in body reserves. The body can store energy as glycogen in liver and muscle cells, and as fat, mainly in adipose tissue. The oxidation of protein yields about $17 \mathrm{~kJ} / \mathrm{g}$, which is comparable to the energy obtained from the oxidation of carbohydrates (52). The storage capacity for glycogen is small, about 400-600 g (53). Therefore, carbohydrates replace fat as a substrate for energy expenditure, as long as carbohydrate energy intake remains less than total energy expenditure (TEE) (54). Only when energy intake from carbohydrates exceeds total energy expenditure, excess carbohydrates are converted to fat (54), of which the storage capacity is much larger. Fat is at the bottom of the hierarchy for substrate utilization for energy expenditure, and has the highest energy density $(38 \mathrm{~kJ} / \mathrm{g})(52)$. It is mainly fat that counterbalances energy imbalances through mobilization and storage. Changes in alcohol, protein and carbohydrate intake elicit acute adjustments in oxidation, whereas a change in fat intake may only induce such a response in the longer-term (55). The fact that energy balance does not automatically implicate 
substrate balance appears when diet composition is changed while maintaining energy balance.

TEE consists of four components; the sleeping metabolic rate (SMR), the energy cost of arousal, the diet-induced thermogenesis (DIT), and the activity energy expenditure (AEE) (3). Usually, SMR and the energy cost of arousal are expressed in a combined component, called basal metabolic rate (BMR). BMR represents energy expenditure at rest, while being awake, in the fasted state, and in a thermoneutral environment (56). BMR accounts on average for $60-80 \%$ of TEE, and is mainly determined by FFM. The increase in energy expenditure above BMR in response to food intake is defined as DIT. This component represents the energy that is required for the initial steps of metabolism and storage, and is therefore dependent on the amount of food ingested $(3,56)$. Furthermore, DIT differs per nutrient being $20-30 \%$ of energy intake for protein, $5-10 \%$ for carbohydrate, $0-3 \%$ for fat, and $10-30 \%$ for alcohol (57). In humans consuming a regular diet in energy balance, DIT accounts on average for $10 \%$ of the energy intake $(58,59)$. AEE, the most variable component of TEE, is determined by body size and physical activity. The physical activity level is defined as TEE divided by BMR. In the majority of humans, the physical activity level ranges from 1.5 to 2.0 (60). This corresponds with an AEE of $10-30 \%$ of TEE.

\section{Body composition}

The general model for body composition is the discrimination between fat mass and FFM. Since FFM is the main determinant of BMR, body composition has a substantial impact on energy expenditure. High-protein diets preserve FFM under negative energy balance (11), and to build-up FFM at a positive energy balance in combination with resistance exercise (13). Therefore, there may be a difference in energy expenditure on high- compared with lower-protein diets in the longer-term.

Fat tissue can be considered as metabolically active tissue as well (61). Subcutaneous adipose tissue, which is located immediately beneath the skin, forms a large part of the total adipose tissue (62). Adipose tissue can also be found in significant amounts around organs and in tissues, such as the liver, pancreas, kidneys and muscles. Besides these fat depots, fat can also accumulate within certain organs and tissues. This fat is referred to as ectopic fat. The processes of fat storage and mobilization in adipose tissue are regulated in a highly coordinated manner depending on energy balance (63). However, a chronic positive energy balance may result in an imbalance in these processes, whereby adipocytes are no longer capable of storing all excess energy. Then, part of the energy is stored as ectopic fat. Increased accumulation of ectopic fat, especially in the liver and pancreas has been linked to the metabolic disturbances associated with obesity, such as a diminished insulin sensitivity and dyslipidemia (64-68). Intrahepatic triglyceride (IHTG) content, and not VAT volume, is an independent risk factor for these metabolic disturbances $(64,65)$. 


\section{Protein turnover}

All proteins in the body are in a constant state of turnover, which means that they are simultaneously synthesized and degraded $(49,69)$. The largest part of protein synthesis involves a recycling of amino acids from protein breakdown, with only a small part obtained from dietary intake. Protein balance is met when protein synthesis equals protein breakdown. A change in the rate of protein turnover does not affect protein balance if breakdown changes to the same extent as synthesis. The processes involved in protein turnover have high energetic costs (70-73). Therefore, changes in the rate of protein turnover may directly affect energy expenditure.

The processes of growth and recovery, as well as of muscle mass accretion require a net protein synthesis. The net balance between muscle protein synthesis and breakdown distinguishes the anabolic state (synthesis exceeds breakdown) from the catabolic state (breakdown exceeds synthesis). Protein or amino acid supplementation effectively stimulates skeletal muscle protein synthesis, inhibits protein breakdown, and therefore, stimulates muscle protein accretion following resistance and endurance exercise (74-76). The synthesis of new protein is derived from the intracellular pool of amino acids. These amino acids can be derived from either protein breakdown or inward transport of amino acids from plasma. A direct relationship has been observed between the total rate of appearance of IAA into the intracellular pool and the rate of muscle protein synthesis. This suggests that homeostasis in protein turnover requires the availability of a sufficient amount of IAA $(77,78)$.

\section{OUTLINE OF THE THESIS}

High-protein diets may constitute beneficial strategies for body weight loss and weight maintenance thereafter (5-7). However, the translation of high-protein diets as a treatment strategy into a preventive measure cannot be taken for granted, because high-protein diets exert different effects in relation to energy balance. In this thesis a series of studies on the interaction of dietary protein with energy balance is presented.

The review presented in Chapter 2 describes the state-of-the-art for the application of relatively high-protein diets in the treatment of obesity. Specific attention is paid to age-dependent protein requirements, the effects of protein intake and protein source, the relevance of other dietary macronutrients, and the mechanisms behind protein-induced appetite control and energy expenditure.

Chapters $\mathbf{3}$ and $\mathbf{4}$ address the question of whether regulatory mechanisms prioritize the intake of protein over that of carbohydrate, fat, and total energy. To investigate this hypothesis, we conducted a series of studies to determine ad libitum energy intake in response to diets with a relative protein content lower 
than, comparable to, and higher than customary diets over 12 consecutive days. Proteins from varying sources were tested to determine whether they affect energy intake or appetite control differently. Measurements of nitrogen balance were applied to assess whether protein intake from low-protein diets was sufficient to meet protein requirements over 12 days (Chapters 4 and 5). More specifically, Chapter 5 describes whether dietary IAA were adequately obtained from diets low in protein or limited in protein variety during the 12-day interventions. Proteininduced satiation has been proposed as a mechanism for the inverse relation between protein intake and energy intake. Therefore, in Chapter 6 the results of studies that assessed the within-subject relations between postprandial changes in hunger and fullness ratings, and the postprandial changes in amino acids, GLP-1, ghrelin, glucose, and insulin concentrations following the consumption of meals differing in protein content and protein source are presented.

After having elaborated on the effects of dietary protein on energy intake, we continued with the investigation of the other side of the energy balance equation, namely energy expenditure. The studies presented in Chapters 7, 8 and $\mathbf{9}$ aimed to determine whether the acute effects observed from high-protein diets in energy balance are transient or sustained. We determined energy expenditure and macronutrient balances on high protein-low carbohydrate and high carbohydratelow protein diets, at a constant body weight, over 12 weeks (Chapter 7). Since FFM and fat mass are both metabolically active tissues, in Chapter 8 we assessed the potential of high protein-low carbohydrate diets compared with high carbohydratelow protein diets to modify or preserve FFM, visceral adipose tissue volume and IHTG content. In Chapter 9 basal whole-body protein balance and fasting muscle protein synthesis were investigated after consuming a high-protein or a lowprotein diet, at a constant body weight, for 12 weeks.

Finally, Chapter $\mathbf{1 0}$ provides a general discussion of the work presented in this thesis. The implications of this work in the prevention and treatment of obesity are discussed, and perspectives for future research are provided. 


\section{REFERENCES}

1. World Health Organization. Obesity and overweight. Fact sheet $\mathrm{N}^{\circ} 311$. Version current March 2013. Internet: http://www.who.int/mediacentre/factsheets/fs311/en/ (assessed 13 May 2014).

2. Abete I, Astrup A, Martinez JA, Thorsdottir I, Zulet MA. Obesity and the metabolic syndrome: role of different dietary macronutrient distribution patterns and specific nutritional components on weight loss and maintenance. Nutr Rev 2010;68:214-31.

3. Westerterp KR. Energy balance in motion. Springer: New York/Dordrecht/London; 2013.

4. Westerterp-Plantenga MS, Nieuwenhuizen A, Tome D, Soenen S, Westerterp KR. Dietary protein, weight loss, and weight maintenance. Annu Rev Nutr 2009;29:21-41.

5. Westerterp-Plantenga MS, Lemmens SG, Westerterp KR. Dietary protein - its role in satiety, energetics, weight loss and health. Br J Nutr 2012;108 Suppl 2:S105-12.

6. Acheson KJ. Diets for body weight control and health: the potential of changing the macronutrient composition. Eur J Clin Nutr 2013;67:462-6.

7. Wycherley TP, Moran L, Clifton PM, Noakes M, Brinkworth GD. Effects of energy-restricted highprotein, low-fat compared with standard-protein, low-fat diets: a meta-analysis of randomized controlled trials. Am J Clin Nutr 2012;96:1281-98.

8. Weigle DS, Breen PA, Matthys CC, Callahan HS, Meeuws KE, Burden VR, Purnell JQ. A high-protein diet induces sustained reductions in appetite, ad libitum caloric intake, and body weight despite compensatory changes in diurnal plasma leptin and ghrelin concentrations. Am J Clin Nutr 2005; 82: 41-8.

9. Westerterp-Plantenga MS, Luscombe-Marsh N, Lejeune MPGM, Diepvens K, Nieuwenhuizen A, Engelen MPKJ, Deutz NEP, Azzout-Marniche D, Tome D, Westerterp KR. Dietary protein, metabolism, and body-weight regulation: dose-response effects. International Journal of Obesity 2006;30:S16-S23.

10. Martens EA, Westerterp-Plantenga MS. Protein diets, body weight loss and weight maintenance. Curr Opin Clin Nutr Metab Care 2014;17:75-9.

11. Soenen S, Martens EA, Hochstenbach-Waelen A, Lemmens SG, Westerterp-Plantenga MS. Normal protein intake is required for body weight loss and weight maintenance, and elevated protein intake for additional preservation of resting energy expenditure and fat free mass. J Nutr 2013; 143:591-6.

12. Bray GA, Smith SR, de Jonge L, Xie H, Rood J, Martin CK, Most M, Brock C, Mancuso S, Redman LM. Effect of dietary protein content on weight gain, energy expenditure, and body composition during overeating: a randomized controlled trial. JAMA 2012;307:47-55.

13. Meredith CN, Frontera WR, O'Reilly KP, Evans WJ. Body composition in elderly men: effect of dietary modification during strength training. J Am Geriatr Soc 1992;40:155-62.

14. Summerbell CD, Douthwaite W, Whittaker V, Ells L, Hillier F, Smith S, Kelly S, Edmunds LD, Macdonald I. The association between diet and physical activity and subsequent excess weight gain and obesity assessed at 5 years of age or older: a systematic review of the epidemiological evidence. Int J Obes (Lond) 2009;33 Suppl 3:S1-92.

15. FAO Statistics Division 2010. Food Balance Sheets. Food and Agriculture Organization of the United Nations. Rome, Italy. Version current March 2011. Available from http://faostat.fao.org/ (assessed 13 May 2014).

16. Bendtsen LQ, Lorenzen JK, N.T. B, Rasmussen C, Astrup A. Effect of dairy proteins on appetite, energy expenditure, body weight, and composition: a review of the evidence from controlled clinical trials. Adv Nutr 2013;4:418-38.

17. Halton TL, Hu FB. The effects of high protein diets on thermogenesis, satiety and weight loss: a critical review. J Am Coll Nutr 2004;23:373-85.

18. Leidy HJ, Armstrong CL, Tang M, Mattes RD, Campbell WW. The influence of higher protein intake and greater eating frequency on appetite control in overweight and obese men. Obesity (Silver Spring) 2010;18:1725-32.

19. Lejeune MP, Westerterp KR, Adam TC, Luscombe-Marsh ND, Westerterp-Plantenga MS. Ghrelin and glucagon-like peptide 1 concentrations, 24-h satiety, and energy and substrate metabolism during a high-protein diet and measured in a respiration chamber. Am J Clin Nutr 2006;83:89-94. 
20. Veldhorst MA, Nieuwenhuizen AG, Hochstenbach-Waelen A, Westerterp KR, Engelen MP, Brummer RJ, Deutz NE, Westerterp-Plantenga MS. Effects of high and normal soyprotein breakfasts on satiety and subsequent energy intake, including amino acid and 'satiety' hormone responses. Eur J Nutr 2009;48:92-100.

21. Veldhorst MA, Nieuwenhuizen AG, Hochstenbach-Waelen A, Westerterp KR, Engelen MP, Brummer RJ, Deutz NE, Westerterp-Plantenga MS. Comparison of the effects of a high- and normal-casein breakfast on satiety, 'satiety' hormones, plasma amino acids and subsequent energy intake. Br J Nutr 2009;101:295-303.

22. Mikkelsen PB, Toubro S, Astrup A. Effect of fat-reduced diets on 24-h energy expenditure: comparisons between animal protein, vegetable protein, and carbohydrate. Am J Clin Nutr 2000; 72:1135-41.

23. Veldhorst MA, Westerterp KR, van Vught AJ, Westerterp-Plantenga MS. Presence or absence of carbohydrates and the proportion of fat in a high-protein diet affect appetite suppression but not energy expenditure in normal-weight human subjects fed in energy balance. Br J Nutr 2010;104: 1395-405.

24. Edholm OG. Energy balance in man studies carried out by the Division of Human Physiology, National Institute for Medical Research. J Hum Nutr 1977;31:413-31.

25. FAO. Dietary protein quality evaluation in human nutrition. Report of an Food and Agriculture Organization Expert Consultation. FAO Food and Nutrition paper 92. Rome, Italy; 2013.

26. WHO/FAO/UNU. Fats and Fatty acids in Human Nutrition. Report of an Expert Consultation. FAO Food and Nutrition Paper 91. Rome, Italy; 2010.

27. WHO/FAO/UNU. Protein and Amino Acid Requirements in Human Nutrition. Report of a Joint WHO/FAO/UNU Expert Consultation. WHO Technical Report Series No 935. Geneva, Italy; 2007.

28. Simpson SJ, Raubenheimer D. Obesity: the protein leverage hypothesis. Obes Rev 2005;6:133-42. Figure 5 The protein leverage effect; p. 138.

29. Simpson SJ, Raubenheimer D. Obesity: the protein leverage hypothesis. Obes Rev 2005;6:133-42.

30. Simpson SJ, Raubenheimer D. The nature of nutrition. A unifying framework from animal adaption to human obesity. Princeton University Press: Princeton, New Jersey; 2012.

31. Veldhorst M, Smeets A, Soenen S, Hochstenbach-Waelen A, Hursel R, Diepvens K, Lejeune M, Luscombe-Marsh N, Westerterp-Plantenga M. Protein-induced satiety: effects and mechanisms of different proteins. Physiol Behav 2008;94:300-7.

32. Morrison CD, Reed SD, Henagan TM. Homeostatic regulation of protein intake: in search of a mechanism. Am J Physiol Regul Integr Comp Physiol 2012;302:R917-28.

33. Fromentin G, Darcel N, Chaumontet C, Marsset-Baglieri A, Nadkarni N, Tome D. Peripheral and central mechanisms involved in the control of food intake by dietary amino acids and proteins. Nutr Res Rev 2012;25:29-39.

34. Acheson KJ, Blondel-Lubrano A, Oguey-Araymon S, Beaumont M, Emady-Azar S, Ammon-Zufferey C, Monnard I, Pinaud S, Nielsen-Moennoz C, Bovetto L. Protein choices targeting thermogenesis and metabolism. Am J Clin Nutr 2011;93:525-34.

35. Hall WL, Millward DJ, Long SJ, Morgan LM. Casein and whey exert different effects on plasma amino acid profiles, gastrointestinal hormone secretion and appetite. Br J Nutr 2003;89:239-48.

36. Veldhorst MA, Nieuwenhuizen AG, Hochstenbach-Waelen A, van Vught AJ, Westerterp KR, Engelen MP, Brummer RJ, Deutz NE, Westerterp-Plantenga MS. Dose-dependent satiating effect of whey relative to casein or soy. Physiol Behav 2009;96:675-82.

37. Mellinkoff SM, Frankland M, Boyle D, Greipel M. Relationship between serum amino acid concentration and fluctuations in appetite. J Appl Physiol 1956;8:535-8.

38. Niijima A, Torii K, Uneyama H. Role played by vagal chemical sensors in the hepato-portal region and duodeno-intestinal canal: An electrophysiological study. Chemical Senses 2005;30:1178-19.

39. Delzenne N, Blundell J, Brouns F, Cunningham K, De Graaf K, Erkner A, Lluch A, Mars M, Peters HP, Westerterp-Plantenga M. Gastrointestinal targets of appetite regulation in humans. Obes Rev 2010;11:234-50.

40. Verdich C, Flint A, Gutzwiller JP, Naslund E, Beglinger C, Hellstrom PM, Long SJ, Morgan LM, Holst $\mathrm{JJ}$, Astrup A. A meta-analysis of the effect of glucagon-like peptide-1 (7-36) amide on ad libitum energy intake in humans. J Clin Endocrinol Metab 2001;86:4382-9. 
41. Flint A, Gregersen NT, Gluud LL, Moller BK, Raben A, Tetens I, Verdich C, Astrup A. Associations between postprandial insulin and blood glucose responses, appetite sensations and energy intake in normal weight and overweight individuals: a meta-analysis of test meal studies. $\mathrm{Br} \mathrm{J}$ Nutr 2007;98: 17-25.

42. Thorens B. Glucose sensing and the pathogenesis of obesity and type 2 diabetes. Int J Obes (Lond) 2008;32 Suppl 6:S62-71.

43. Lemmens SG, Martens EA, Kester AD, Westerterp-Plantenga MS. Changes in gut hormone and glucose concentrations in relation to hunger and fullness. Am J Clin Nutr 2011;94:717-25.

44. Cummings DE, Frayo RS, Marmonier C, Aubert R, Chapelot D. Plasma ghrelin levels and hunger scores in humans initiating meals voluntarily without time- and food-related cues. Am J Physiol Endocrinol Metab 2004;287:E297-304.

45. Guyton AC, hall JE. Textbook of Medical Physiology. Pennsylvania: Elsevier Inc; 2006.

46. Johnstone AM, Horgan GW, Murison SD, Bremner DM, Lobley GE. Effects of a high-protein ketogenic diet on hunger, appetite, and weight loss in obese men feeding ad libitum. Am J Clin Nutr 2008;87: 44-55.

47. Veldhorst MA, Westerterp KR, Westerterp-Plantenga MS. Gluconeogenesis and protein-induced satiety. Br J Nutr 2012;107:595-600.

48. Tome D, Bos C. Dietary protein and nitrogen utilization. J Nutr 2000;130:1868S-73S.

49. Millward DJ. Identifying recommended dietary allowances for protein and amino acids: a critique of the 2007 WHO/FAO/UNU report. Br J Nutr 2012;108 Suppl 2:S3-21.

50. Millward DJ. Amino acid scoring patterns for protein quality assessment. Br J Nutr 2012;108 Suppl 2:S31-43.

51. Tome D. Criteria and markers for protein quality assessment - a review. Br J Nutr 2012;108 Suppl 2:S222-9.

52. Atwater WO, Bryant AP. The availability and fuel value of food materials. Agriculture Experiment Station 12th Annual Report 73-110. Washington, DC: US Government Printing Office; 1900.

53. McArdle WD, Katch FI, Katch VL. Exercise Physiology: Energy, Nutrition and Human Performance. Lippincott Williams and Wilkins: Philadelphia; 2007.

54. Hellerstein MK. De novo lipogenesis in humans: metabolic and regulatory aspects. Eur J Clin Nutr 1999; 53 Suppl 1:S53-65.

55. Schrauwen $P$, Lichtenbelt WD, Saris WH, Westerterp KR. Fat balance in obese subjects: role of glycogen stores. Am J Physiol 1998;274:E1027-33.

56. Westerterp KR. Energy expenditure. In: Westerterp-Plantenga MS, Fredrix EWHM, Steffens AB, eds. Food intake and energy expenditure. CRC PRess;1994:235-57.

57. Tappy L. Thermic effect of food and sympathetic nervous system activity in humans. Reprod Nutr Dev 1996;36:391-7.

58. Westerterp KR. Diet induced thermogenesis. Nutr Metab (Lond) 2004;1:5.

59. Westerterp KR, Wilson SA, Rolland V. Diet induced thermogenesis measured over $24 \mathrm{~h}$ in a respiration chamber: effect of diet composition. Int J Obes Relat Metab Disord 1999;23:287-92.

60. Westerterp KR. Alterations in energy balance with exercise. Am J Clin Nutr 1998;68:970S-4S.

61. Frayn KN. Adipose tissue as a buffer for daily lipid flux. Diabetologia 2002;45:1201-10.

62. Thomas EL, Fitzpatrick JA, Malik SJ, Taylor-Robinson SD, Bell JD. Whole body fat: content and distribution. Prog Nucl Magn Reson Spectrosc 2013;73:56-80.

63. Frayn KN. Integration of substrate flow in vivo: some insights into metabolic control. Clin Nutr 1997; 16:277-82.

64. Fabbrini E, Magkos F, Mohammed BS, Pietka T, Abumrad NA, Patterson BW, Okunade A, Klein S. Intrahepatic fat, not visceral fat, is linked with metabolic complications of obesity. Proc Natl Acad Sci U S A 2009;106:15430-5.

65. Magkos F, Fabbrini E, Mohammed BS, Patterson BW, Klein S. Increased whole-body adiposity without a concomitant increase in liver fat is not associated with augmented metabolic dysfunction. Obesity (Silver Spring) 2010;18:1510-5.

66. Hwang JH, Stein DT, Barzilai N, Cui MH, Tonelli J, Kishore P, Hawkins M. Increased intrahepatic triglyceride is associated with peripheral insulin resistance: in vivo MR imaging and spectroscopy studies. Am J Physiol Endocrinol Metab 2007;293:E1663-9. 
67. Dubois M, Kerr-Conte J, Gmyr V, Bouckenooghe T, Muharram G, D'Herbomez M, Martin-Ponthieu A, Vantyghem MC, Vandewalle B, Pattou F. Non-esterified fatty acids are deleterious for human pancreatic islet function at physiological glucose concentration. Diabetologia 2004;47:463-9.

68. Tushuizen ME, Bunck MC, Pouwels PJ, Bontemps S, van Waesberghe JH, Schindhelm RK, Mari A, Heine RJ, Diamant M. Pancreatic fat content and beta-cell function in men with and without type 2 diabetes. Diabetes Care 2007;30:2916-21.

69. Wolfe RR. Protein Synthesis and Breakdown. In: Radioactive and Stable Isotope Tracers in Biomedicine: Principles and Practice of Kinetic Analysis. Wiley; 1992.

70. Koopman R, Walrand S, Beelen M, Gijsen AP, Kies AK, Boirie Y, Saris WH, van Loon LJ. Dietary protein digestion and absorption rates and the subsequent postprandial muscle protein synthetic response do not differ between young and elderly men. J Nutr 2009;139:1707-13.

71. Pennings B, Boirie $Y$, Senden JM, Gijsen AP, Kuipers H, van Loon L. Whey protein stimulates postprandial muscle protein accretion more effectively than do casein and casein hydrolysate in older men. Am J Clin Nutr 2011;93:997-1005.

72. Pennings B, Koopman R, Beelen M, Senden JM, Saris WH, van Loon LJ. Exercising before protein intake allows for greater use of dietary protein-derived amino acids for de novo muscle protein synthesis in both young and elderly men. Am J Clin Nutr 2011;93:322-31.

73. van Loon L, Boirie Y, Gijsen AP, Fauquant J, de Roos AL, Kies AK, Lemosquet S, Saris WH, Koopman R. The production of intrinsically labeled milk protein provides a functional tool for human nutrition research. J Dairy Sci 2009;92:4812-22.

74. Biolo G, Tipton KD, Klein S, Wolfe RR. An abundant supply of amino acids enhances the metabolic effect of exercise on muscle protein. Am J Physiol 1997;273:E122-9.

75. Witard OC, Tieland M, Beelen M, Tipton KD, van Loon $\amalg$, Koopman R. Resistance exercise increases postprandial muscle protein synthesis in humans. Med Sci Sports Exerc 2009;41:144-54.

76. van Loon LJ, Gibala MJ. Dietary protein to support muscle hypertrophy. Nestle Nutr Inst Workshop Ser 2011;69:79-95.

77. Wolfe RR. The role of dietary protein in optimizing muscle mass, function and health outcomes in older individuals. Br J Nutr 2012;108 Suppl 2:S88-93.

78. Volpi E, Campbell WW, Dwyer JT, Johnson MA, Jensen GL, Morley JE, Wolfe RR. Is the optimal level of protein intake for older adults greater than the recommended dietary allowance? J Gerontol A Biol Sci Med Sci 2013;68:677-81. 


\section{CHAPTER 2}

Protein diets, body weight loss and

weight maintenance

Martens EA, Westerterp-Plantenga MS

Curr Opin Clin Nutr Metab Care 2014;17:75-9 


\section{ABSTRACT}

\section{Purpose of review}

The review addresses briefly the relevance of protein diets for body weight loss and weight maintenance. The addition of recent findings on age-dependent protein requirements, specific effects of protein intake and protein source, the relevance of the other dietary macronutrients, especially of 'low-carb', 'protein leverage', the mechanisms of proteininduced satiety, and food-reward makes the review up-to-date.

\section{Recent findings}

Different effects of protein diets in different age groups result from age-dependent protein requirements that are primarily related to effects on body composition. A protein intake of $0.8 \mathrm{~g} / \mathrm{kg}$ body weight $/ \mathrm{d}$ is sufficient to sustain a negative energy balance in adults, irrespective of the protein source. 'Low-carb' diets trace back to the protein-induced effects. Evidence that protein intake drives energy intake as suggested by the protein leverage hypothesis is scarce and equivocal. Finally, limited protein-induced food reward may affect compliance to a protein diet.

\section{Summary}

An implication of the findings for clinical practice is that a protein intake of $0.8-1.2 \mathrm{~g} / \mathrm{kg}$ body weight/d is sufficient to sustain satiety, energy expenditure, and fat-free mass, independent of a dietary 'low-carb' content. Limited protein-induced food reward may affect compliance to a protein diet. 


\section{INTRODUCTION}

Dietary treatment of obesity implies loss of body weight, which requires a negative energy balance. The most efficient and effective way to achieve a negative energy balance is by applying an energy-restriction diet. Usually, this intervention increases the feelings of hunger and desire to eat, and decreases the feeling of fullness, which increases the risk for regain of body weight. This needs to be prevented. In addition, the usual reduction in energy expenditure and fat-free mass (FFM) during body weight loss should be prevented. This can be achieved by applying a protein diet (1). Specification of protein diets is necessary. The agedependent protein requirements, and the protein intake, protein source, and further macronutrient composition of the diet need to be considered. The protein leverage hypothesis is a relatively new concept, that is, a 'protein target' to drive energy intake. In addition, novel insights into appetite control mechanisms and reward homeostasis have recently been developed. For a comparison of long-term studies, we only cite studies that employed a biomarker to confirm compliance with the designated protein intake. The aim of this review is to specify how protein diets can be applied as a clinical approach for body weight loss and weight maintenance.

\section{PROTEIN REQUIREMENT AND AGE}

Adults require a protein intake of at least $0.66 \mathrm{~g} / \mathrm{kg}$ body weight $(\mathrm{BW}) / \mathrm{d}$ to maintain nitrogen-balance $\left(2^{* *}\right)$. Nitrogen balance depends on nitrogen needed for both the maintenance, and in the case of growth, additional protein deposition in newly formed tissues. An average value of $70 \%$ can be considered for the efficiency of dietary protein utilization, whereas this value can vary with factors such as protein quality $\left(3,4^{* *}, 5\right)$. Age-related changes in protein metabolism, such as the decrease in whole body protein synthesis from $17.4 \mathrm{~g} / \mathrm{kg} \mathrm{BW} / \mathrm{d}$ in newborns to 6.9 $\mathrm{g} / \mathrm{kg} \mathrm{BW} / \mathrm{d}$ in infants, $3.0 \mathrm{~g} / \mathrm{kg} \mathrm{BW} / \mathrm{d}$ in adults to $1.9 \mathrm{~g} / \mathrm{kg} \mathrm{BW} / \mathrm{d}$ in the elderly, result in different protein requirements $\left(2^{* *}\right)$. Age-dependent protein requirements imply differing roles of dietary protein in different age groups.

From a limited source of older, but classic articles, it appears that in specific age groups higher protein intakes mainly affect body composition, and not body weight. In newborns, infants and children, a higher-protein intake led to a higher gain of FFM (6-11). In the elderly, a sustained protein intake may attenuate loss of FFM.

Despite a reduction in energy requirements, protein requirements are unaltered in the elderly. This results from a decreased protein synthesis and a lower protein digestibility, coinciding with larger protein breakdown $\left(4^{* *}\right)$. Agerelated loss of FFM is an effect of ageing itself, rather than the result of insufficient 
protein intake. However, maintaining protein intake could stimulate muscle protein synthesis, which may slow down the loss of FFM $\left(12^{*}, 13^{*}\right)$. Compared with adults, this means that the relative proportion of protein in the diet should increase in order to counteract the unfavorable effects of ageing on protein metabolism.

\section{EFFECTS OF PROTEIN INTAKE, PROTEIN-SOURCE, AND MACRONUTRIENT COMPOSITION OF PROTEIN-DIETS FOR BODY-WEIGHT LOSS AND WEIGHT MAINTENANCE}

High-protein diets support a negative energy balance, as shown by results from intervention studies $\left(1,14,15^{* *}\right)$. Monitoring and confirming compliance with the designated protein intake by a biomarker, such as urinary nitrogen, is necessary to evaluate the efficacy of protein diets. Studies on protein diets have used large ranges of protein intake vs. control, and contained mixed sources of protein (1). Considering protein intake, studies have compared high-protein with mediumprotein or low-protein energy-restriction diets (1). Specific effects of protein intake and source of protein on body weight loss were evaluated in a series of 6-month energy-restriction studies comparing protein intake just above the minimum requirement of $0.66 \mathrm{~g} / \mathrm{kg} \mathrm{BW} / \mathrm{d}(0.8 \mathrm{~g} / \mathrm{kg} \mathrm{BW} / \mathrm{d})$ with well above the minimum requirement $(1.2 \mathrm{~g} / \mathrm{kg} \mathrm{BW} / \mathrm{d})\left(16,17^{*}, 18^{*}\right)$. During energy restriction, sustaining protein intake at the level of requirement appeared to be sufficient to induce body weight loss while preserving FFM. Protein intake above requirement resulted in a stronger decrease in fat mass and preservation of FFM, but had no effect on body weight loss $\left(18^{*}\right)$. Also, protein source had no effect on body weight loss $\left(16,17^{*}\right)$. Similar results were found for weight maintenance after weight loss $\left(16,17^{*}, 18^{*}\right)$. Diets with protein contents below requirement appeared to increase the risk of body weight regain. The use of these diets as control diets contributes to the observed differences in outcomes of energy-restricted protein-diet studies $\left(1,15^{* *}, 18^{*}\right)$.

Several of the earlier studies claimed, that the favorable effects on body weight loss were observed because of the diet being 'low-carb' (14). In response, possible effects of the macronutrient composition of protein diets were assessed in a dietary intervention study over 12 mo. (19). It turned out that effects of high protein content on body weight loss and weight maintenance were present independent of the carbohydrate content, while the low carbohydrate content did not show independent effects (19).

A specific application of high-protein diets is used after bariatric surgery, as protein malnutrition is a commonly observed phenomenon, postoperatively (20). In patients, adherence to an energy-restricted, relatively high-protein diet is associated with improvements in nutritional status, with improvements in the feelings of satiety, with body weight loss, and improved body composition. 
Regarding the protein source, specifically high leucine content appeared to be relevant for maintaining muscle mass (20).

It is important to note that the observations described above, describe results from intervention studies applying favorable effects of protein intake during negative energy balance, thereby preventing or minimizing the unfavorable effects of negative energy balance. Observational studies do not necessarily show the same associations when assessing protein intake under everyday conditions, and not during energy restriction (21).

Sustaining original protein intake while decreasing fat and carbohydrate intake, as is advocated above for a protein intake of $0.8 \mathrm{~g} / \mathrm{kg} \mathrm{BW} / \mathrm{d}$, alludes to the protein leverage hypothesis. This hypothesis encompasses a geometrical model suggesting that protein intake depends on an individual-specific protein target, thus driving energy intake $\left(22,23^{*}\right)$. This protein target might adjust food intake depending on the relative protein content of the diet. Possible underlying mechanisms have been tested in a study design with the relative protein content of a diet as an independent variable, and the total fat along with carbohydrate intake, or total energy intake, as a dependent variable. Earlier field studies showed that animals underate relative to energy balance on higher-protein diets, and overate on lowerprotein diets (23*). However, a recent animal study by Rothman et al. (24) did not find any evidence to support this hypothesis. An intervention study in humans showed compensatory protein intake after consuming an energy-balanced lowprotein diet (25). A this study was not designed to measure protein leverage effects, a clear conclusion on energy intake driven by macronutrient composition could not be drawn (25).

A 12-d randomized crossover study conducted in energy balance, in which protein was exchanged with carbohydrate, while palatability was matched, observed a significantly lower ad-libitum energy intake from meals containing $30 \mathrm{En} \%$ from protein, but no higher energy intake from 5En\%-protein meals, compared with $15 \mathrm{En} \%$-protein meals $\left(26^{*}\right)$. Thus, 'protein leverage' affected energy intake on $30 \mathrm{En} \%$-protein diets, but not on $5 \mathrm{En} \%$-protein diets when protein was replaced with carbohydrate. It is suggested that it may be the fat content that drives energy intake on low-protein diets. Overeating of energy-dense high-fat foods, that are automatically low in protein, reduces the En\% from protein in the diet. Control over energy intake may be easily overruled by a high-fat intake when protein intake is low, or by a high-protein intake when above the level of requirement $\left(26^{*}\right)$. It can be speculated that protein intake may be directed by a certain range aiming to prevent shortage or excess intake $\left(26^{*}, 27,28^{*}\right)$.

The classical multifactorial hypothesis regarding the mechanisms behind the effects of protein diets still holds, and new insights show that a protein intake of $0.8 \mathrm{~g} / \mathrm{kg} \mathrm{BW} / \mathrm{d}$ is sufficient to sustain satiety, energy expenditure, and FFM, whereas a higher protein intake of the diet, for example, $1.2 \mathrm{~g} / \mathrm{kg} \mathrm{BW} / \mathrm{d}$ increases FFM. Protein source does not affect body weight management. A 'low-carb' diet 
being high in protein relies upon the protein-induced effects, independent of the 'low-carb' effects per se. Evidence for a target for protein intake driving energy intake, as hypothesized by protein leverage so far is scarce and equivocally.

\section{MECHANISMS BEHIND PROTEIN-INDUCED APPETITE CONTROL AND ENERGY EXPENDITURE}

High-protein intake sustains the original appetite profile, despite energy restriction. Proposed mechanisms are as follows: a ketogenic state, relatively elevated plasma amino acid, anorexigenic hormone concentrations, and increases in diet-induced energy expenditure, all feeding back on the central nervous system $(1,29 * *)$. With respect to the ketogenic effect; fasting $\beta$-hydroxybutyrate concentrations and gluconeogenesis were increased after a ketogenic high-protein, 'low-carb' diet compared with an isoenergetic normal-protein, normal-carbohydrate diet for 1.5 days $(30 *)$. The increased concentrations of $\beta$-hydroxybutyrate directly affected appetite suppression, whereas gluconeogenesis and appetite ratings were unrelated to each other. However, a study on gluconeogenesis and energy expenditure after a high-protein, carbohydrate-free diet showed that $42 \%$ of the increase in energy expenditure after the high-protein diet was explained by the increase in gluconeogenesis (31).

Amino acid-related effects have been shown with whey protein, showing a high and early rise in plasma amino acid concentrations coinciding with a stronger decrease in hunger ratings compared with casein (32). A high-casein protein breakfast was more satiating than a normal-casein breakfast, coinciding with prolonged elevated concentrations of plasma amino acids (33). Also, a high-soyprotein breakfast was more satiating than a normal-soyprotein breakfast, related to a larger increase in taurine concentrations, which is derived from the amino acids cysteine and methionine (34).

Anorexigenic gut hormones such as peptide YY, glucagon-like peptide-1, and cholecystokinine are produced in response to peripheral and central detection of amino acids. They react on elevated protein intake from specific sources and act on brain areas involved in the control of food intake $\left(27,28^{*}, 32,35^{* *}\right)$. High-protein intake directly affects the activation of the arcuate nucleus and the nucleus tractus solitarius in the brain, resulting in a suppressed food intake, at least acutely $(29 * *)$. The latter observation may underscore a limited protein-induced food-reward effect, which may limit compliance to a protein-diet. 


\section{REWARD HOMEOSTASIS RELATED TO DIETARY PROTEIN}

Reward-driven eating behavior may dominate energy homeostasis $\left(28^{*}, 29 * *, 36^{*}, 37^{*}, 38\right)$. Several brain areas that are involved in food reward might link high-protein intake with reduced food wanting and thereby act as a mechanism involved in the reduced energy intake following high protein intake $\left(28^{*}, 29 * *, 36^{*}\right.$, $\left.37^{*}, 38\right)$. A hypothesized mechanism by which protein might act on brain reward centres involves direct effects of certain amino acids as precursors of the neuropeptides, serotonin, and dopamine $\left(28^{*}, 29 * *\right)$. A high-protein, lowcarbohydrate breakfast vs. a normal-protein, high-carbohydrate breakfast led to reduced reward-related activation in the hippocampus and parahippocampus before dinner $\left(35^{* *}\right)$. Furthermore, acute food-choice compensation changed the macronutrient composition of a subsequent meal in a compensatory direction $\left(36^{*}\right)$. A compensatory increase in carbohydrate intake was related to a decrease in liking and task-related signalling in the hypothalamus after a highprotein breakfast. After a lower-protein breakfast, an increase in wanting and task-related signalling in the hypothalamus was related to a relative increase in protein intake in a subsequent meal $\left(36^{*}\right)$. Protein intake may directly affect the rewarding value of this macronutrient $\left(25,36^{*}\right)$. These phenomena may also explain an occasional lack of compliance to protein-diets.

\section{ADVERSE EFFECTS OF PROTEIN-DIETS}

High-protein intake might interfere with calcium homeostasis by increasing the acid load. This could be partially buffered by bone, subsequently resulting in bone resorption and hypercalciuria $\left(39^{* *}\right)$. However, this can be neutralized by consuming alkalirich foods such as fruits and vegetables (40). In general, highprotein intake does not seem to be associated with an impaired calcium balance. Clinically, large prospective epidemiologic studies have shown positive associations of protein intake with bone mineral mass and reduced incidence of osteoporotic fracture (41). Furthermore, nitrogen intake seems to have a positive effect on calcium balance and consequent preservation of bone mineral content (42). With respect to renal issues, only patients with a pre-existing dysfunction appeared to have an increased risk for the development of kidney stones and renal diseases $\left(39^{* *}\right)$. Recent insight into the composition of infant nutrition indicates that protein intake above requirements may predispose infants to the development of overweight and obesity. In the elderly, health-beneficial effects of higher-protein intake might outweigh the adverse effects possibly because of the changes in protein metabolism with ageing. On the contrary, persistent total protein and amino acid intake below requirements impairs bodily functions leading to higher disease and mortality risks across the lifespan $(4 * *, 43)$. Taken together, application 
of relatively high-protein diets, whereby protein intake is sustained the original level, does not seem to have any adverse effects in healthy individuals.

\section{CONCLUSION}

In conclusion, insight that different effects of protein diets in different age groups are primarily related to effects on body composition adds to the prevailing evidence and opinion that the effects of protein diets on body weight loss and weight maintenance mainly hold for adults. In adults, a protein intake of 0.8-1.2 g/kg BW/d is sufficient to sustain satiety, energy expenditure, and FFM, independent of a dietary 'low-carb' content. This implies that protein intake does not need to be exceptionally high to be used for body weight management, thus avoiding adverse effects. New for clinical practice is the special focus on leucine content showing that high-protein diets could also successfully be used after bariatric surgery. Until now, the mainly investigated and cited mechanisms behind proteininduced satiety are the reputed increase in anorexigenic hormone concentrations. In addition, the present review highlights the contributions of a ketogenic state, relatively elevated plasma amino acid concentrations, and increases in diet-induced energy expenditure, all feeding back on the central nervous system. The recent observations on limited protein-induced food reward, potentially affecting compliance to a protein diet, sheds light on the necessity of future interdisciplinary research in the fields of food technology, satiety physiology, and reward physiology.

\section{ACKNOWLEDGEMENTS}

We acknowledge Tanja C.M. Adam for reviewing the manuscript. 


\section{REFERENCES AND RECOMMENDED READING}

Papers of particular interest, published within the annual period of review, have been highlighted as:

* of special interest; ${ }^{* *}$ of outstanding interest

1. Westerterp-Plantenga MS, Lemmens SG, Westerterp KR. Dietary protein - its role in satiety, energetics, weight loss and health. Br J Nutr 2012;108 Suppl 2:S105-112.

2.** FAO. Dietary protein quality evaluation in human nutrition: Report of an FAO Expert Consultation. FAO Food and Nutrition paper 92. Rome: FAO; 2013.

A new method for evaluating protein quality 'Digestible Indispensable Amino Acid Score' (DIAAS) is recommended to replace the 'Protein Digestibility Corrected Amino Acid Score' (PDCAAS) to recalculate age-dependent amino-acid requirements, and to clarify different effects of highprotein diets in special age groups.

3. Millward DJ. Amino acid scoring patterns for protein quality assessment. Br J Nutr 2012;108 Suppl 2:S31-43.

4. ** Tome D. Criteria and markers for protein quality assessment - a review. Br J Nutr 2012;108 Suppl 2:S222-229.

A clear overview of different approaches to define protein requirements including protein quality, which is of major relevance to provide insight into the capacity of different dietary proteins to satisfy protein requirements.

5. Gilani GS, Xiao CW, Cockell KA. Impact of Antinutritional Factors in Food Proteins on the Digestibility of Protein and the Bioavailability of Amino Acids and on Protein Quality. Br J Nutr 2012;108:S315-S332.

6. Hester SN, Hustead DS, Mackey AD, et al. Is the macronutrient intake of formula-fed infants greater than breast-fed infants in early infancy? J Nutr Metab 2012;2012:891201.

7. Koletzko $B$, von Kries $\mathrm{R}$, Closa $\mathrm{R}$, et al. Lower protein in infant formula is associated with lower weight up to age 2 y: a randomized clinical trial. Am J Clin Nutr 2009;89:1836-1845.

8. de Bruin NC, Degenhart HJ, Gal S, et al. Energy utilization and growth in breast-fed and formulafed infants measured prospectively during the first year of life. Am J Clin Nutr 1998;67:885-896.

9. Wauben I, Westerterp K, Gerver WJ, et al. Effect of varying protein intake on energy balance, protein balance and estimated weight gain composition in premature infants. Eur J Clin Nutr 1995;49:11-16.

10. van Vught AJ, Heitmann BL, Nieuwenhuizen AG, et al. Association between intake of dietary protein and 3-year-change in body growth among normal and overweight 6-year-old boys and girls (CoSCIS). Public Health Nutr 2010;13:647-653.

11. van Vught AJ, Heitmann BL, Nieuwenhuizen AG, et al. Association between dietary protein and change in body composition among children (EYHS). Clin Nutr 2009;28:684-688.

12. * Wolfe RR. The role of dietary protein in optimizing muscle mass, function and health outcomes in older individuals. Br J Nutr 2012;108 Suppl 2:S88-93.

A new insight into the benefits of application of high-protein diets to slow down the age-related loss of FFM by maintaining protein intake at the level of requirement.

13. * Volpi E, Campbell WW, Dwyer JT, et al. Is the optimal level of protein intake for older adults greater than the recommended dietary allowance? J Gerontol A Biol Sci Med Sci 2013;68: 677-681.

This study provides insight into the importance of adequate protein intake to stimulate muscle protein-synthesis in older adults, and thereby stresses the benefits of the application of highprotein diets.

14. Acheson KJ. Diets for body weight control and health: the potential of changing the macronutrient composition. Eur J Clin Nutr 2013;67:462-466.

15. ** Wycherley TP, Moran LJ, Clifton PM, et al. Effects of energy-restricted high-protein, low-fat compared with standard-protein, low-fat diets: a meta-analysis of randomized controlled trials. Am J Clin Nutr 2012;96:1281-1298. 
The first systematic review and meta-analysis of energy-matched protein-diets with a $>10 \mathrm{En \%}$ protein difference between high- and standard-protein diets confirms the satiety, energy expenditure, and FFM response to body-weight loss.

16. Hochstenbach-Waelen A, Soenen S, Westerterp KR, et al. Effects of a supra-sustained gelatinmilk protein diet compared with (supra-)sustained milk protein diets on body-weight loss. Br J Nutr 2011;105:1388-1398.

17. * Soenen S, Hochstenbach-Waelen A, Westerterp-Plantenga MS. Efficacy of alpha-lactalbumin and milk protein on weight loss and body composition during energy restriction. Obesity (Silver Spring) 2011;19:370-379.

A 6-month body-weight loss, weight maintenance study shows that maintaining protein intake from the level of $0.8 \mathrm{~g} / \mathrm{kg} / \mathrm{d}$ is sufficient, while $1.2 \mathrm{~g} / \mathrm{kg} / \mathrm{d}$ is necessary for increasing FFM.

18. * Soenen S, Martens EA, Hochstenbach-Waelen A, et al. Normal protein intake is required for body weight loss and weight maintenance, and elevated protein intake for additional preservation of resting energy expenditure and fat free mass. J Nutr 2013;143:591-596.

A 1-year body-weight loss, weight maintenance study comparing four energy-restricted diets with combinations of high-protein/normal-protein and 'low carb'/normal-carbohydrate shows that body-weight loss and weight maintenance effects are due to the independent effects of a high-protein intake.

19. Soenen S, Bonomi AG, Lemmens SG, et al. Relatively high-protein or 'low-carb' energy-restricted diets for body weight loss and body weight maintenance? Physiol Behav 2012;107:374-380.

20. Faria SL, Faria OP, Buffington C, et al. Dietary protein intake and bariatric surgery patients: a review. Obes Surg 2011;21:1798-1805.

21. Halkjaer J, Olsen A, Overvad K, et al. Intake of total, animal and plant protein and subsequent changes in weight or waist circumference in European men and women: the Diogenes project. Int J Obes (Lond) 2011;35:1104-1113.

22. Simpson SJ, Raubenheimer D. Obesity: the protein leverage hypothesis. Obes Rev 2005;6: 133-142.

23. ** Simpson SJ RD. The nature of nutrition. A Unifying framework from animal adaptation to human obesity. Princeton and Oxford: Princeton University Press; 2012.

The 'protein leverage' hypothesis provides a model in which protein intake is kept constant while changing fat and carbohydrate intake, and may be used as background to discuss the effects of energy-restricted, high-protein diets.

24. Rothman JM, Raubenheimer D, Chapman CA. Nutritional geometry: gorillas prioritize nonprotein energy while consuming surplus protein. Biol Lett 2011;7:847-849.

25. Griffioen-Roose S, Mars M, Siebelink E, et al. Protein status elicits compensatory changes in food intake and food preferences. Am J Clin Nutr 2012;95:32-38.

26. * Martens EA, Lemmens SG, Westerterp-Plantenga MS. Protein leverage affects energy intake of high-protein diets in humans. Am J Clin Nutr 2013;97:86-93.

A well-controlled cross-over study showing evidence for high-protein leverage, but not for lowprotein leverage.

27. Morrison CD, Reed SD, Henagan TM. Homeostatic regulation of protein intake: in search of a mechanism. Am J Physiol Regul Integr Comp Physiol 2012;302:R917-928.

28. * Davidenko O, Darcel N, Fromentin G, et al. Control of protein and energy intake - brain mechanisms. Eur J Clin Nutr 2013;67:455-461.

Integration of observations from peripheral signals and from the central control of protein intake into the view that the target for protein intake directs towards avoiding deficiency or excess intake.

29. ** Journel M, Chaumontet C, Darcel N, et al. Brain responses to high-protein diets. Adv Nutr 2012;3:322-329.

In addition to the direct effects of dietary protein on reward-driven eating behaviour, also interactions between homeostatic and hedonic control mechanisms of protein intake affect eating behaviour.

30. * Veldhorst MA, Westerterp KR, Westerterp-Plantenga MS. Gluconeogenesis and protein-induced satiety. Br J Nutr 2012;107:595-600. 
Increases in ketogenesis in response to high-protein diets directly contribute to appetite suppression.

31. Veldhorst MA, Westerterp-Plantenga MS, Westerterp KR. Gluconeogenesis and energy expenditure after a high-protein, carbohydrate-free diet. Am J Clin Nutr 2009;90:519-526.

32. Veldhorst MA, Nieuwenhuizen AG, Hochstenbach-Waelen A, et al. Dose-dependent satiating effect of whey relative to casein or soy. Physiol Behav 2009;96:675-682.

33. Veldhorst MA, Nieuwenhuizen AG, Hochstenbach-Waelen A, et al. Comparison of the effects of a high- and normal-casein breakfast on satiety, 'satiety' hormones, plasma amino acids and subsequent energy intake. Br J Nutr 2009;101:295-303.

34. Veldhorst MA, Nieuwenhuizen AG, Hochstenbach-Waelen A, et al. Effects of high and normal soyprotein breakfasts on satiety and subsequent energy intake, including amino acid and 'satiety' hormone responses. Eur J Nutr 2009;48:92-100.

35. ** Leidy HJ, Ortinau LC, Douglas SM, et al. Beneficial effects of a higher-protein breakfast on the appetitive, hormonal, and neural signals controlling energy intake regulation in overweight/obese, "breakfast-skipping," late-adolescent girls. Am J Clin Nutr 2013;97:677-688. Integrated measurements of appetitive, hormonal, and neural signals in response to dietary protein, show and interaction between energy-and reward-homeostasis.

36. * Born JM, Martens MJ, Lemmens SG, et al. Protein v. carbohydrate intake differentially affects liking- and wanting-related brain signalling. Br J Nutr 2013;109:376-381.

A direct relationship between changes in protein intake and reward-related brain signalling, underscoring subsequent food-choice compensation.

37. * Fromentin G, Darcel N, Chaumontet C, et al. Peripheral and central mechanisms involved in the control of food intake by dietary amino acids and proteins. Nutr Res Rev 2012;25:29-39.

A significant contribution to the knowledge regarding protein-gut-brain interactions, thereby strengthening the suggested association between protein-diets and food reward.

38. Lemmens SG, Martens EA, Born JM, et al. Lack of effect of high-protein vs. high-carbohydrate meal intake on stress-related mood and eating behavior. Nutr J 2011;10:136.

39. ** Calvez J, Poupin N, Chesneau C, et al. Protein intake, calcium balance and health consequences. Eur J Clin Nutr 2012;66:281-295.

This review concludes from controlled dietary intervention studies that high-protein diets are in general safe to be applied for body weight management. High-protein diets are not necessary very high in total protein content to induce beneficial effects.

40. Barzel US, Massey LK. Excess dietary protein can adversely affect bone. J Nutr 1998;128: 1051-1053.

41. Bonjour JP. Dietary protein: an essential nutrient for bone health. J Am Coll Nutr 2005;24: 526S-536S.

42. Westerterp KR. Weight loss and bone mineral content. Obes Res 2002;10:559.

43. Moughan PJ. Dietary protein for human health. Br J Nutr 2012;108 Suppl 2:S1-2. 


\title{
CHAPTER 3
}

\author{
Protein leverage affects energy intake \\ of high-protein diets in humans
}

Martens EA, Lemmens SG, Westerterp-Plantenga MS

Am J Clin Nutr 2013;97:86-93 


\section{ABSTRACT}

\section{Background}

The protein leverage hypothesis requires specific evidence that protein intake is regulated more strongly than energy intake.

\section{Objective}

The objective was to determine ad libitum energy intake, body weight changes, and appetite profile in response to protein-to-carbohydrate + fat ratio over 12 consecutive days and in relation to age, sex, BMI, and type of protein.

\section{Design}

A 12-d randomized crossover study was performed in 40 men and 39 women [mean \pm SD age: $34.0 \pm 17.6 \mathrm{y}$; $\mathrm{BMI}\left(\right.$ in $\mathrm{kg} / \mathrm{m}^{2}$ ): $23.7 \pm 3.4$ ] with the use of diets containing $5 \%, 15 \%$, and $30 \%$ of energy from protein from a milk or plant source.

\section{Results}

Protein-content effects did not differ by age, sex, BMI, or type of protein. Total energy intake was significantly lower in the high-protein $(7.21 \pm 3.08 \mathrm{MJ} / \mathrm{d})$ condition than in the lowprotein $(9.33 \pm 3.52 \mathrm{MJ} / \mathrm{d})$ and normal-protein $(9.62 \pm 3.51 \mathrm{MJ} / \mathrm{d})$ conditions $(P=0.001)$, which was predominantly the result of a lower energy intake from meals $(P=0.001)$. Protein intake varied directly according to the amount of protein in the diet $(P=0.001)$. The AUC of visual analog scale appetite ratings did not differ significantly, yet fluctuations in hunger $(P=0.019)$ and desire to eat $(P=0.026)$ over the day were attenuated in the high-protein condition compared with the normal-protein condition.

\section{Conclusions}

We found evidence to support the protein leverage hypothesis in that individuals underate relative to energy balance from diets containing a higher protein-to-carbohydrate + fat ratio. No evidence for protein leverage effects from diets containing a lower ratio of proteinto-carbohydrate + fat was obtained. It remains to be shown whether a relatively low protein intake would cause overeating or would be the effect of overeating of carbohydrate and fat. The study was registered at clinicaltrials.gov as NCT01320189. 


\section{INTRODUCTION}

Obesity is reaching epidemic proportions in a growing number of countries and is associated with several related health problems such as type 2 diabetes and cardiovascular diseases $(1,2)$. The development of obesity results from a chronic energy imbalance, with energy intake exceeding energy expenditure. After the focus of weight-loss strategies regarding food intake regulation on changes in carbohydrate and fat consumption, the role of protein has recently received considerable attention (2). According to the protein leverage hypothesis developed by Simpson and Raubenheimer (3), even small changes in the dietary percentage of protein may have substantial effects on energy intake. Early studies in insects (4), a reanalysis of data from studies in chickens $(5)$ and rats $(6,7)$, laboratory studies in rodents $(8,9)$, and a more recent study in free-living monkeys $(10)$ suggest that protein intake is maintained at a more constant level than is that of carbohydrate and fat. However, it is still unknown whether dietary protein exerts leverage to drive energy intake in humans or whether overeating predominantly occurs with carbohydrate and fat, thereby automatically decreasing the relative proportion of protein in the diet $(11,12)$, whereas overeating of protein is prevented by its highly satiating effect (13). Weigle et al. (14) showed that a high-protein diet $(30 \%$ of energy from protein) compared with a normal-protein diet produced a sustained decrease in ad libitum energy intake and related weight loss. Griffioen-Roose et al. (15) showed in a 4-d study that subjects increased their protein intake in a compensatory way during ad libitum feeding after a low-protein diet ( $5 \%$ of energy from protein). Also, Gosby et al. (16) showed from a short-term, in-house dietary manipulation study that lean subjects consumed on average $10 \%$ more energy on a moderate-low protein diet ( $10 \%$ of energy from protein) compared with a normalprotein diet. Proposed mechanisms for the inverse relation between dietary protein intake and energy intake may be increased satiety due to a relatively high protein content $(17,18)$. Several studies showed that, in energy balance, highprotein diets reduced postprandial hunger and increased postprandial satiety $(14,19,20)$.

The protein leverage hypothesis requires specific evidence on cause and effectie, that protein intake is regulated more strongly than energy intake or that, depending on energy intake, with absolute protein intake being relatively stable (in $\mathrm{g} / \mathrm{kg}$ body weight) (1), relative protein intake automatically varies with energy intake. Therefore, we carried out a controlled dietary intervention study to determine ad libitum energy intake, body weight changes, and appetite profile in response to protein-to-carbohydrate + fat ratio over 12 consecutive days and in relation to age, sex, BMI, and type of protein. Following the analyses by Stock (21) and by Simpson and Raubenheimer (3), isoenergetic diets with a large range in protein concentrations $(5 \%, 15 \%$, and $30 \%$ of energy from protein) were provided whereby protein was exchanged for carbohydrate. Proteins from varying sources, 
namely milk protein (whey protein with $\alpha$-lactalbumin) and plant protein (soy protein), were used, because they may differ in their effects on energy intake or in possible adaptations in appetite profile (22-24).

\section{SUBJECTS AND METHODS}

The Medical Ethical Committee of the Maastricht University approved the study, and all participants gave written informed consent. The study was registered at clinicaltrials.gov as NCT01320189.

\section{Study subjects}

On the basis of the study by Weigle et al. (14), power analysis showed that with an $\alpha$ of 0.0167 (significance level for each test: $\alpha=0.05$, taking into account the Bonferroni correction for multiple testing) and a $b$ of $0.10, \geq 81$ subjects were needed. Ninety subjects were recruited by advertisements in local newspapers and on notice boards at the university; 9 of these subjects dropped out due to lack of time. Two subjects were excluded from the data analysis because of noncompliance, as shown by the urinary nitrogen biomarker. Overall, 79 subjects (40 men and 39 women) were included in the final data analysis. To cover a wide range of BMls, subjects were normal weight, overweight, or obese [BMI range (in $\mathrm{kg} / \mathrm{m}^{2}$ ): 18.2 - 33.9]; to include the lifespan to a large extent, they were between 18 and 70 y old. BMI and age were equally divided between the male and female groups. Subjects underwent a screening that included anthropometric measurements and the completion of questionnaires.

Body weight was measured by using a digital balance, and height was measured by using a wall-mounted stadiometer. BMI was calculated as body weight (kg) divided by height $(\mathrm{m})$ squared. Waist and hip circumferences were determined in standing position by using a tape measure. Waist circumference was measured at the smallest circumference between the rib cage and iliac crest, and hip circumference was measured at the level of the spina iliaca anterior superior. Accordingly, waist-to-hip ratio was calculated by dividing waist by hip circumference.

Subjects completed questionnaires related to health, smoking behavior, use of medication, alcohol consumption, physical activity, eating behavior, anxiety, and liking of the study meals. Subjects were nonsmoking, not using more than moderate amount of alcohol ( $>10$ drinks/wk), weight stable (body weight change of $<3 \mathrm{~kg}$ during the last $6 \mathrm{mo}$ and no planned weight change during the study period), and not using medications or supplements except for oral contraceptives in women. 
The validated Dutch translation of the Baecke Activity Questionnaire was used to measure habitual physical activity (25). This questionnaire consists of 3 indexes of physical activity, namely work, sport, and leisure time (26). Eating behavior was analyzed using a validated Dutch translation of the Three Factor Eating Questionnaire (TFEQ), which measures the 3 factors involved in eating behavior, namely "cognitive restraint of eating", "disinhibition of restraint", and "hunger" $(13,27)$. On the basis of the median of the TFEQ scores in the population from the south of the Netherlands, dietary restraint was defined by TFEQ dietary restraint scores $\geq 9$. Dietary restraint scores $<9$ indicated dietary unrestraint (28). High disinhibition was defined by TFEQ disinhibition scores $\geq 5$, and scores $<5$ represented low disinhibition. Trait anxiety level was scored by means of the StateTrait Anxiety Inventory questionnaire (29).

Small portions of the study meals were served to test the palatability and acceptability of the study meals, and visual analogue scales (VASs) were used to assess liking. These 100-mm scales were anchored with "not at all" at one end and "extremely" at the other end. Subjects had to make a single vertical mark at the appropriate point between the 2 anchors on each scale. Only subjects who rated the taste of the meals as sufficient (VAS score for liking: $\geq 50 \mathrm{~mm}$ ) were included in the study.

\section{Study design}

The study used a single-blind crossover design with 3 randomly sequenced experimental conditions that differed in relative protein content of the provided meals. Subjects visited the university to consume breakfast, lunch, and dinner ad libitum in the research restaurant for 12 consecutive days in each condition. The reason for the use of the 12-d time period is the phenomenon that energy balance is regulated over a week and that at least this period of time is needed to show a possible effect on body weight (30). Subsequent test sessions started $8 \mathrm{wk}$ after the start of the preceding one and included a washout period of $\sim 6 \mathrm{wk}$ to prevent possible treatment-induced effects and to take possible effects of menstrual cycle phase on energy intake of women into account $(31,32)$. Two different protein isolates were used: whey protein with $\alpha$-lactalbumin (Hiprotal Whey Protein Alpha, Domo; FrieslandCampina) and soy protein (SUPRO Soy Protein Isolate; Solae, LLC). Subjects were randomly assigned to either the whey-protein group or the soyprotein group.

\section{Diet composition}

The 3 applied conditions differed in relative protein content of the meals: $5 \%$ of energy, $15 \%$ of energy, and $30 \%$ of energy from protein (Table 3.1 ). Because the intake and storage for carbohydrate are regulated over a shorter period of time than for fat (33) and to prevent bias caused by the possible effects of energy 
density on energy intake, the fat content between meals and between conditions was maintained at a constant proportion (35\% of energy from fat) (33). Another reason to keep the proportion of fat relatively constant is to prevent subjects from overeating on a high-fat diet, which is usually caused by taste and energy density $(34,35)$. Thus, protein was completely exchanged by carbohydrate. The resulting protein-to-carbohydrate + fat ratios (\% of energy) of the diets were 5:95 (lowprotein), 15:85 (normal-protein), and 30:70 (high-protein). All meals (breakfast, lunch, and dinner) within each condition had the same macronutrient composition. Moreover, all food items, and the energy density, weight and volume of the meals were the same between conditions (Table 3.1).

Table 3.1 Composition of the study diets: whey and soy protein combined

\begin{tabular}{lccc}
\hline & \multicolumn{2}{c}{ Percentage of energy from protein } \\
\cline { 2 - 4 } & $5 \%$ & $15 \%$ & $30 \%$ \\
\hline Breakfast & & & \\
Protein (\% of energy) & $5.05 \pm 0.03^{1}$ & $15.01 \pm 0.03$ & $30.00 \pm 0.04$ \\
Carbohydrate (\% of energy) & $59.93 \pm 0.09$ & $49.90 \pm 0.20$ & $34.94 \pm 0.22$ \\
Fat (\% of energy) & $35.01 \pm 0.06$ & $35.09 \pm 0.18$ & $35.06 \pm 0.18$ \\
Protein:carbohydrate + fat (\% of energy) & $5: 95^{2}$ & $15: 85$ & $30: 70$ \\
Energy density (kJ/g) & $7.21 \pm 0.33$ & $7.23 \pm 0.04$ & $7.18 \pm 0.10$ \\
Lunch & & & \\
Protein (\% of energy) & $5.15 \pm 0.20$ & $14.95 \pm 0.03$ & $30.00 \pm 0.02$ \\
Carbohydrate (\% of energy) & $59.80 \pm 0.21$ & $50.00 \pm 0.03$ & $35.04 \pm 0.05$ \\
Fat (\% of energy) & $35.06 \pm 0.01$ & $35.04 \pm 0.00$ & $34.96 \pm 0.05$ \\
Protein:carbohydrate + fat (\% of energy) & $5: 95$ & $15: 85$ & $30: 70$ \\
Energy density (kJ/g) & $8.69 \pm 0.34$ & $8.72 \pm 0.20$ & $8.69 \pm 0.27$ \\
Dinner & & & \\
Protein (\% of energy) & $5.20 \pm 0.13$ & $14.99 \pm 0.01$ & $30.06 \pm 0.08$ \\
Carbohydrate (\% of energy) & $59.82 \pm 0.03$ & $49.97 \pm 0.01$ & $35.65 \pm 0.15$ \\
Fat (\% of energy) & $34.98 \pm 0.12$ & $35.04 \pm 0.01$ & $35.04 \pm 0.07$ \\
Protein:carbohydrate + fat (\% of energy) & $5: 95$ & $15: 85$ & $30: 70$ \\
Energy density (kJ/g) & $5.49 \pm 0.07$ & $5.49 \pm 0.07$ & $5.46 \pm 0.10$ \\
\hline
\end{tabular}

${ }^{1}$ Mean \pm SD (all such values); ${ }^{2}$ Mean ratio (all such values).

The energy content of the meals was calculated from the nutrition information on the food items or from the standard Dutch NEVO food-composition table. Breakfast was composed of breakfast cereals (Kellogg's Nederland) moistened with orange juice (not milk). Lunch consisted of bread with vegetable salad, and dinner was composed of pasta with tomato sauce. Initially, all meals were low in protein content. Whey and soy protein isolates were used to exchange carbohydrate with protein in the normal- and high-protein conditions to reach the proportions of protein according to the study design.

Food was served as ready-to-eat meals to prevent selective consumption of food items within meals. Three different variants for breakfast, lunch, and dinner were offered in each condition to decrease the possible effects of boredom on 
energy intake and appetite profile. Meals were provided ad libitum for $30 \mathrm{~min}$, and subjects were instructed to eat until they felt comfortably full. A fixed amount of $300 \mathrm{ml}$ of water per subject was offered with each meal.

After each meal, snack items were provided in individual boxes for ad libitum consumption at home. All snack items were very low in protein content ( $\sim 5 \%$ of energy from protein) to reduce interference with the protein intake during the test meals. The provided snack items were the same after each meal and in each condition. Subjects were instructed to bring all leftovers back during their visit to the research restaurant for the subsequent meal. Subjects were allowed to drink water, tea, and coffee without added milk or sugar ad libitum between the meals, but no other foods or beverages were allowed to be consumed.

\section{Biomarker of protein intake}

Nitrogen excretion, measured from 24-h urine collections at baseline (day 0 ) and at days 5 and 11, was used as biomarker for protein intake. Urine was collected in 2-I urine bottles with $10 \mathrm{ml}$ of diluted hydrochloric acid $(4 \mathrm{mmol} / \mathrm{l})$ added to prevent nitrogen loss through evaporation. Collection started after the first voiding in the morning on the collection days at 8:00h and lasted until and with the first voiding on the next day at 8:00h. The total volume of the $24-\mathrm{h}$ urine was recorded. Urine was gently mixed, and samples were taken and frozen at $-20^{\circ} \mathrm{C}$ until analysis. Nitrogen concentrations were measured with a nitrogen analyzer (CHN-ORapid;Hereaus). Total nitrogen output was calculated as 24-h urinary nitrogen plus $10 \%$ to account for normal losses via feces and other losses.

\section{Energy and macronutrient intake}

Each meal was weighed, to the nearest gram, before it was provided to the subjects. Leftovers were weighed, after which energy and macronutrient intakes were calculated per subject. The provided snack items were also recorded, and the leftovers that had to be brought back were weighed to determine the energy and macronutrient intake from the snacks per subject. Mean total energy intake was calculated as the sum of energy intake from meals and the reported mean energy intake from snacks. Individual daily energy requirements were calculated as the resting metabolic rate according to the formula of Harris and Benedict (36) times the physical activity level based on the Baecke Activity Questionnaire (26). Energy balance was determined as the difference between energy requirement and energy intake.

\section{Appetite profile}

Appetite profile was measured by means of the VAS. These $100-\mathrm{mm}$ scales were anchored with 'not at all' at one end and 'extremely' at the other end and 
combined with questions on feelings of hunger, satiety, fullness, thirst, and desire to eat. Before and after breakfast, lunch, and dinner, subjects had to complete the VAS.

\section{Body weight}

Body weight was measured in the fasted state in the morning of days 1, 6, and 12 .

\section{Statistical analysis}

SPSS version 19 for Macintosh OS X (SPSS Inc) was used to perform statistical analyses. Data are presented as means \pm SDs.

Differences in subject characteristics between sexes and protein groups (whey compared with soy) were evaluated by using factorial ANOVA. The AUC over the day was calculated for VASs for hunger, fullness, satiety, and desire to eat by using the trapezoidal method. Amplitude scores were calculated for all appetite measures to assess fluctuations over the day. The scores were calculated by using VASs, by subtracting the minimum score from the maximum score. Factorial ANOVAs with repeated measures were used to test whether nitrogen excretion and VAS ratings changed over time within conditions (low protein, normal protein, high protein) and to test whether nitrogen excretion, VAS ratings, amplitude scores, or the effects of sex and protein group on differences in energy intake, macronutrient intake, and body weight change differed in response to protein-tocarbohydrate + fat ratio. Bonferroni correction for multiple comparisons and post hoc analyses were applied with all ANOVA tests.

Simple linear regression analyses were used to determine the contribution of age and BMI to the prediction of energy intake and body weight changes, in response to protein-to-carbohydrate + fat ratio. Differences were regarded as significant if $P<0.05$.

\section{RESULTS}

\section{Subject characteristics}

Subject characteristics are summarized in Table 3.2. No significant differences were observed between the 2 protein groups at baseline with regard to anthropometric measurements, physical activity, eating behavior, and anxiety. Age and BMI ranges were comparable between both protein groups. 
Table 3.2 Subject characteristics in the whey- and soy-protein groups ${ }^{1}$

\begin{tabular}{lcc}
\hline \hline & Whey-protein group & Soy-protein group \\
\hline No. of subjects (M/F) & $39(16 / 23)$ & $40(24 / 16)$ \\
Age $(\mathrm{y})$ & $34.5 \pm 16.8^{2}$ & $33.6 \pm 18.6$ \\
Age range (y) & $18-70$ & $18-69$ \\
Height $(\mathrm{cm})$ & $171.7 \pm 10.6$ & $174.0 \pm 9.6$ \\
Weight $(\mathrm{kg})$ & $68.6 \pm 13.8$ & $73.6 \pm 12.3$ \\
BMI $\left(\mathrm{kg} / \mathrm{m}^{2}\right)$ & $23.1 \pm 3.5$ & $24.3 \pm 3.2$ \\
BMI range $\left(\mathrm{kg} / \mathrm{m}^{2}\right)$ & $18.2-33.9$ & $18.1-33.4$ \\
Waist circumference $(\mathrm{cm})$ & $77.6 \pm 11.6$ & $80.9 \pm 10.5$ \\
Hip circumference $(\mathrm{cm})$ & $100.9 \pm 6.2$ & $103.2 \pm 7.0$ \\
WHR & $0.77 \pm 0.08$ & $0.78 \pm 0.08$ \\
BMR (MJ/d) & $6.5 \pm 1.2$ & $6.9 \pm 1.0$ \\
PAL & $1.76 \pm 0.15$ & $1.75 \pm 0.14$ \\
DER (MJ/d) & $11.4 \pm 2.0$ & $12.1 \pm 2.1$ \\
Baecke work score & $2.4 \pm 0.5$ & $2.4 \pm 0.6$ \\
Baecke sport score & $3.3 \pm 1.3$ & $3.4 \pm 1,1$ \\
Baecke leisure-time score & $3.4 \pm 0.4$ & $3.2 \pm 0.6$ \\
Baecke total score & $9.1 \pm 1.4$ & $9.0 \pm 1.4$ \\
TFEQ dietary restraint score & $6.0 \pm 4.0$ & $4.8 \pm 2.9$ \\
TFEQ disinhibition score & $3.8 \pm 1.9$ & $4.0 \pm 1.9$ \\
TFEQ hunger score & $3.8 \pm 3.0$ & $4.0 \pm 3.2$ \\
STAl score & $31.8 \pm 8.0$ & $31.3 \pm 7.4$ \\
\hline
\end{tabular}

${ }^{1}$ There were no significant differences between the protein groups (factorial ANOVA). BMR, basal metabolic rate; DER, daily energy requirement; PAL, physical activity level; STAI, State-Trait Anxiety Inventory; TFEQ, Three-Factor Eating Questionnaire; WHR, waist-to-hip ratio; ${ }^{2}$ Mean \pm SD (all such values).

\section{Biomarker of protein intake}

Baseline nitrogen excretion did not differ significantly between conditions $(9.7 \pm$ $3.8 \mathrm{~g} / \mathrm{d}$ ), which indicates that subjects had a normal protein intake at the start of each test period. Nitrogen excretion significantly decreased in the low-protein condition to $5.0 \pm 1.6 \mathrm{~g} / \mathrm{d}(P=0.001)$ and increased in the high-protein condition to $13.7 \pm 6.1 \mathrm{~g} / \mathrm{d}(P=0.001)$ compared with baseline. In the normal-protein condition, nitrogen excretion did not change significantly throughout the test period $(8.3 \pm 3.4$ $\mathrm{g} / \mathrm{d})$. Nitrogen excretion differed significantly between the conditions, thereby confirming significant differences in protein intake between conditions $(P=0.001)$. In each condition, no significant differences between the urine collection days 5 and 11 were observed, which indicated stable protein intakes within the conditions over the $12-d$ test periods.

\section{Energy and macronutrient intake}

Age, sex, BMI, and type of protein did not have an effect on differences in energy and macronutrient intake between conditions. Mean protein intake from meals over $12 \mathrm{~d}$ varied directly with the amount of protein in the diet $(P=0.001$; Table 
3.3). Mean carbohydrate intake was significantly different between conditions $(P=$ 0.001; Table 3.3), with the highest intake in the low-protein condition and the lowest intake in the high-protein condition.

Table 3.3 Mean energy and macronutrient intake and change in body weight over $12 \mathrm{~d}$ between conditions: whey-protein and soy-protein groups combined $(n=79)^{1}$

\begin{tabular}{lccc}
\hline & \multicolumn{3}{c}{ Percentage of energy from protein } \\
\cline { 2 - 4 } & $5 \%$ & $15 \%$ & $30 \%$ \\
\hline Energy intake (MJ/d) & $9.33 \pm 3.52^{2, \mathrm{a}}$ & $9.62 \pm 3.51^{\mathrm{a}}$ & $7.21 \pm 3.08^{\mathrm{b}}$ \\
Total & $2.15 \pm 2.09^{\mathrm{a}}$ & $2.44 \pm 2.35^{\mathrm{a}}$ & $1.16 \pm 1.13^{\mathrm{a}}$ \\
Snacks & $7.18 \pm 2.38^{\mathrm{a}}$ & $7.13 \pm 2.39^{\mathrm{a}}$ & $6.04 \pm 2.12^{\mathrm{b}}$ \\
Meals & $2.56 \pm 0.91^{\mathrm{a}}$ & $2.38 \pm 0.91^{\mathrm{b}}$ & $2.19 \pm 0.93^{\mathrm{c}}$ \\
Breakfast & $2.10 \pm 0.90^{\mathrm{a}}$ & $2.02 \pm 0.88^{\mathrm{a}}$ & $1.56 \pm 0.68^{\mathrm{b}}$ \\
Lunch & $2.52 \pm 0.99^{\mathrm{a}}$ & $2.73 \pm 1.03^{\mathrm{b}}$ & $2.29 \pm 0.94^{\mathrm{c}}$ \\
Dinner & & & \\
Protein intake, meals & $0.36 \pm 0.12^{\mathrm{a}}$ & $1.07 \pm 0.36^{\mathrm{b}}$ & $1.81 \pm 0.64^{\mathrm{c}}$ \\
(MJ/d) & $0.3 \pm 0.1^{\mathrm{a}}$ & $0.9 \pm 0.3^{\mathrm{b}}$ & $1.6 \pm 0.5^{\mathrm{c}}$ \\
(g/kg BW/d) & & & \\
Carbohydrate intake, meals & $4.31 \pm 1.43^{\mathrm{a}}$ & $3.57 \pm 1.20^{\mathrm{b}}$ & $2.12 \pm 0.74^{\mathrm{c}}$ \\
(MJ/d) & $3.7 \pm 1.2^{\mathrm{a}}$ & $3.1 \pm 1.1^{\mathrm{b}}$ & $1.8 \pm 0.6^{\mathrm{c}}$ \\
(g/kg BW/d) & & & \\
Fat intake, meals & $2.51 \pm 0.83^{\mathrm{a}}$ & $2.50 \pm 0.84^{\mathrm{a}}$ & $2.12 \pm 0.74^{\mathrm{b}}$ \\
(MJ/d) & $1.0 \pm 0.3^{\mathrm{a}}$ & $1.0 \pm 0.3^{\mathrm{a}}$ & $0.8 \pm 0.3^{\mathrm{b}}$ \\
(g/kg BW/d) & $5: 95^{3}$ & $15: 85$ & $30: 70$ \\
Protein:carbohydrate + fat & $5: 95$ & $12: 88$ & $23: 77$ \\
Meals (\% of energy) & $-0.9 \pm 1.1$ & $-0.8 \pm 1.0$ & $-1.0 \pm 1.0$ \\
$\Delta \mathrm{BW}$ day12-day1 (kg) & $-2.48 \pm 2.92^{\mathrm{a}}$ & $-2.20 \pm 2.84^{\mathrm{a}}$ & $-4.61 \pm 4.64^{\mathrm{b}}$ \\
Energy balance (MJ/d) & & &
\end{tabular}

${ }^{1}$ Values with different superscript letters are significantly different, $P<0.05$ (repeated-measures ANOVA with Bonferroni correction for pairwise post hoc comparisons). BW, body weight; ${ }^{2}$ Mean \pm SD (all such values); ${ }^{3}$ Mean ratio (all such values).

An increase in protein-to-carbohydrate + fat ratio of meals resulted in significant undereating relative to energy balance $(P=0.001)$, whereas a decrease in protein-to-carbohydrate + fat ratio did not significantly affect energy intake (Table 3.3; Figure 3.1). As a result of the lower mean energy intake from meals, fat intake was significantly lower in the high-protein condition than in the low-protein $(P=0.001)$ and normal-protein $(P=0.001)$ conditions (Table 3.3).

The lower mean energy intake from meals in the high-protein condition, compared with the low- and normal-protein conditions, respectively, was also present as a lower mean energy intake during all separate meals: breakfast $(P=0.001, P=0.004)$, lunch $(P=0.001, P=0.001)$, and dinner $(P=0.013, P=0.001)$. Significant differences between the low- and normal-protein conditions were observed in mean energy intake during breakfast $(P=0.018)$ and dinner $(P=0.047)$, with a higher mean energy intake during breakfast and a lower mean energy intake during dinner in the low-protein condition than in the normal-protein condition. 
In each condition, individual daily energy intake from meals was similar throughout the days (skewness values of $0.54,0.66$, and 0.35 and kurtosis values of $-0.57,-0.26$, and -0.60 for the low-, normal-, and high-protein conditions, respectively).

Energy intake from snacks did not significantly differ between conditions (Table 3.3).

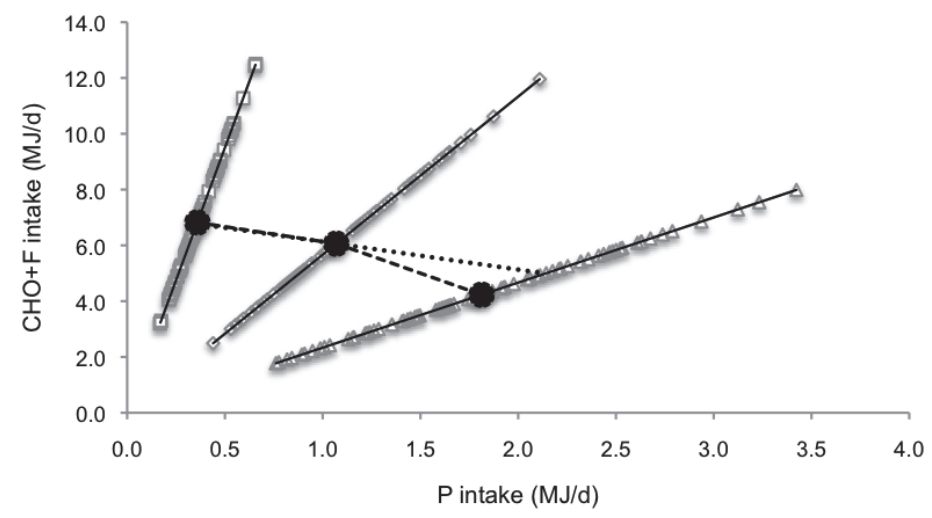

Figure 3.1 Relation between mean protein intake (MJ/d) and mean carbohydrate + fat intake $(\mathrm{MJ} / \mathrm{d})$ in response to diets differing in protein-to-carbohydrate + fat ratio for $12 \mathrm{~d}$. Betweensubject effects are expressed as individual means for the $5 \%$ of energy from protein condition (white squares), the $15 \%$ of energy from protein condition (white diamonds), and the $30 \%$ of energy from protein condition (white triangles); within-subject effects are expressed as group means (black circles). The dashed line combines group means, and the dotted line represents intakes of protein and carbohydrate + fat that may occur if intakes were regulated to energy intake in the $15 \%$ of energy from protein condition. The differences between the dashed line and the dotted line show the degree to which carbohydrate + fat intake is balanced against protein intake. $\mathrm{CHO}$, carbohydrate; $\mathrm{F}$, fat; $\mathrm{P}$, protein.

\section{Appetite profile}

Before breakfast, VASs for hunger, desire to eat, fullness, and satiety were not significantly different between the conditions. Consumption of the meals induced significant decreases in mean VASs for hunger and desire to eat and significant increases in mean VASs for fullness and satiety $(P=0.001)$ in all conditions over the $12-d$ test periods. Despite differences in energy intake, no significant differences in hunger, desire to eat, fullness, and satiety over the day were observed between conditions, expressed as mean AUC over the 12-d test periods. Significant lower amplitude values showed less fluctuation in hunger $(P=0.019)$ and desire to eat $(P=0.026)$ in the high-protein condition ( $57 \pm 19$ and $58 \pm 21$, respectively) over the day compared with the normal protein condition $(60 \pm 19$ and $62 \pm 21$, respectively). 
Mean VASs for liking showed that subjects rated the meals as sufficiently palatable except for the lunch in the high-protein condition. VAS liking scores for lunch in the high-protein condition were significantly lower than those in the lowand normal-protein conditions $(P=0.001)$. VAS liking scores for dinner were significantly higher in the whey-protein group compared with the soy-protein group (condition 3 protein interaction, $P=0.023$ ), but energy intake during dinner was not significantly different between both protein groups.

\section{Body weight and energy balance}

During the test periods, mean body weight gradually decreased from day 1 to day 12 in all 3 conditions $(P=0.001)$, which implies that subjects were in negative energy balance in all conditions (Table 3.3). The decrease in body weight did not differ between conditions. Subjects consistently regained their original body weight before the subsequent test session started. Mean energy deficit was significantly greater in the high-protein condition than in the low- and normal-protein conditions (Table 3.3).

\section{DISCUSSION}

The protein leverage hypothesis requires specific evidence that protein intake is regulated more strongly than energy intake. Results from our study provide evidence that supports the protein leverage hypothesis with respect to effects from diets containing a higher protein-to-carbohydrate + fat ratio. Individuals underate relative to energy balance, predominantly from meals in the high-protein condition. No evidence for protein leverage effects from diets containing a lower ratio of protein to carbohydrate + fat was obtained. Nitrogen excretion measurements confirmed that protein intake varied directly with the amount of protein in the diet. Differences in energy intake between conditions were not influenced by age, sex, BMI, or type of protein.

Although the mean energy balance was different between conditions, body weight loss did not differ significantly. This is likely to be due to a fat-free masssparing effect in the high-protein condition. Body weight loss with an energydeficient, normal-protein diet consists of loss of fat mass of $60-75 \%$ and of loss of fat-free mass of $25-40 \%$. The corresponding energy equivalent of the body weight loss is $30 \mathrm{MJ} / \mathrm{kg}$ (37). Body weight loss with an energy-deficient, high-protein diet consists of nearly only loss of fat mass and no loss of fat-free mass. The corresponding energy equivalent of the body weight loss then is $\sim 52 \mathrm{MJ} / \mathrm{kg}$ $(21,37,38)$. Although the duration of the test periods was sufficient to measure differences in body weight change, it was not long enough to reliably measure differences in body composition $(34,39)$. 
Appetite scores were similar between the conditions, despite the interventioninduced lower energy intake in the high-protein condition, which indicates that subjects were similarly satiated and satisfied by the diets, including less eating with a high-protein diet. These results confirm the observations by Weigle et al. (14). Fluctuation over the day in hunger and desire to eat was lower in the high-protein condition than in the normal-protein condition. Less pronounced fluctuation in appetite may indicate more stable levels of appetite hormones and insulin over the day, which may improve control over food intake (40).

Gosby et al. (16) also tested the protein leverage hypothesis and showed that compared with a normal-protein diet (15\% of energy from protein), human subjects had a higher energy intake with a moderately low-protein diet (10\% of energy from protein), whereas energy intake with a high-protein diet ( $25 \%$ of energy from protein) was not different. Similar between the studies was the aim to test protein leverage in a randomized well-controlled experimental study by using a variety of foods and some food choice wherein protein (not being deficient in amino acids) and carbohydrate were exchanged and energy density and palatability were kept similar. A difference in the design between the present study and that of Gosby et al. was the relative protein content of the diets: $5 \%$ of energy, $15 \%$ of energy, and $30 \%$ of energy from protein compared with $10 \%$ of energy, $15 \%$ of energy, and $25 \%$ of energy from protein, respectively. Further differences in the design between the studies were the number of subjects ( $n=79$ compared with $n=22$ ), characteristics of the subjects (mean \pm SD age: $34.0 \pm 17.6$ compared with $24.3 \pm 1.3$ y; BMI: $23.7 \pm 3.4$ compared with $21.8 \pm 0.4$; age range: $18-70$ compared with 18-51 y; BMI range: 18-34 compared with 18-26), duration of the experiments ( 3 times for $12 \mathrm{~d}$ compared with 3 times for $4 \mathrm{~d}$ ), measurement of possible changes in body weight (measurement of significant changes is possible over $12 \mathrm{~d}$, whereas this is not applicable over $4 \mathrm{~d}$ ), and measurements of further subject characteristics, such as waist-to-hip ratio, dietary restraint, and physical activity scores, and calculations of physical activity level, basal metabolic rate, and daily energy requirement in the present study.

A similarity in the outcome was the higher total energy intake in the lower compared with the higher protein condition. This indicates that a proteinleveraging mechanism might work between relatively low and relatively high protein diets. However, there is a discrepancy in the results between the studies with respect to energy intake from the $15 \%$ of energy from protein diets. The present study observed an energy intake similar to the $5 \%$ of energy from protein diet, whereas Gosby et al. observed an energy intake similar to the $25 \%$ of energy from protein diet. The main discrepancy in protein-induced energy intake differences results from the fact that the present study observed these differences from meals, thus as a satiation effect, whereas Gosby et al. observed these differences from snacks, thus a satiety and food-choice effect. We speculate that the satiation effect may be caused by the larger difference in the protein content of 
the diets. Nitrogen contents of the urinary samples indicated large and constant differences in protein intake between the conditions, which was not the case in Gosby et al. The lack of an effect from snack intake in the present study may be due to the availability of only reported snack intake, which has created large SDs and implies the possibility of uncontrolled snack intake during the hours that subjects were away from the study site, a consequence of the number of subjects and the duration of the experiment.

The strength of the present study was the complete control over energy and macronutrient intake from 3 meals per day over a period of $12 \mathrm{~d}$ in a large number of subjects, including both sexes and with a large range in age and BMI, and the nitrogen contents of the urinary samples, which indicated large and constant differences in protein intake between the conditions.

Meal times were scheduled in consultation with the subjects, taking their preferred meal times into account. The slight difference in palatability of the lunches observed in the present study was not related to differences in total energy intake.

To unravel the possible mechanism behind the protein leverage hypothesis, it is necessary to show a direct effect on energy intake from a relatively low and a relatively high protein diet. To our knowledge, until now, studies have observed only one side, either from a low-protein diet $(15,16)$ or from a high-protein diet (14). Observational studies, either from food-intake surveys $(1,41)$ or from ecological field studies $(4,10)$, showed a relative constant absolute protein intake, which may fluctuate relatively depending on energy intake. The driving force behind the observations may have been prevention of overeating with a highprotein diet $(17,18,20,24,42-45)$ and overeating easily with a high-carbohydrate, high-fat diet $(33-35,46,47)$. More research is necessary to unravel cause and effect taking all macronutrients into account.

The prevention of overeating with a high-protein diet also is in line with the hypothesis of Stock (21), which suggests that energy efficiency is influenced by dietary protein content. Thermogenesis may be increased with unbalanced diets in an effort to homeostatically expend excess energy (21). Overeating easily may have been prevented in the present study because an exchange of only protein and carbohydrate took place, and possible overeating on a relatively high-fat diet was impossible (47).

Another explanation may be maintenance of protein balance, which is essential for normal growth and development in organisms. This requires homeostasis in total nitrogen intake and in the intake of essential amino acids. A proposed mechanism to prevent nitrogen imbalance may be related to an observed signaling pathway for detection of amino acid depletion. Reduced concentrations of essential amino acids in the anterior piriform cortex in the brain may lead to deacetylation of the cognate transfer RNA (48). Subsequent activation of general amino acid nonderepressing kinase 2 may phosphorylate eukaryotic initiation 
factor $2 \alpha$, a factor involved in the control of the initiation of translation in protein synthesis, leading to behavioral responses (48-56).

To conclude, we found evidence to support the protein leverage hypothesis in that individuals underate relative to energy balance from diets containing a higher protein-to-carbohydrate + fat ratio. No evidence for protein leverage effects from diets containing a lower ratio of protein to carbohydrate + fat was obtained. It remains to be shown whether a relatively low protein intake would cause overeating or would be the effect of overeating of carbohydrate and fat.

\section{ACKNOWLEDGEMENTS}

We thank our subjects for their participation in the study and Mandy Dunlop, Alexandra Kiskini, Ruben Drost, Laura Muskens, Claudia Cangialosi, Giel Caelen, Yolanda Daems, Floor van den Brand, Celeste van Rinsum, Inge Bobbert, and Blandine Cherifi-Gatta for their help with the practical work. Nitrogen analyses were performed by Hasibe Aydeniz. 


\section{REFERENCES}

1. World Health Organization. Obesity and overweight. Fact sheet $N^{\circ} 311$. Version current May 2012. Internet: http://www.who.int/mediacentre/factsheets/fs311/en/ (assessed 4 July 2012).

2. Abete I, Astrup A, Martinez JA, Thorsdottir I, Zulet MA. Obesity and the metabolic syndrome: role of different dietary macronutrient distribution patterns and specific nutritional components on weight loss and maintenance. Nutr Rev 2010;68:214-231.

3. Simpson SJ, Raubenheimer D. Obesity: the protein leverage hypothesis. Obes Rev 2005;6:133-142.

4. Raubenheimer D, Simpson SJ. Integrative models of nutrient balancing: application to insects and vertebrates. Nutr Res Rev 1997;10:151-179.

5. Shariatmadari F, Forbes JM. Growth and food intake responses to diets of different protein contents and a choice between diets containing two concentrations of protein in broiler and layer strains of chicken. Br Poult Sci 1993;34:959-970.

6. Tews JK, Repa JJ, Harper AE. Protein selection by rats adapted to high or moderately low levels of dietary protein. Physiol Behav 1992;51:699-712.

7. Theall CL, Wurtman JJ, Wurtman RJ. Self-selection and regulation of protein: carbohydrate ratio in foods adult rats eat. J Nutr 1984;114:711-718.

8. Sorensen A, Mayntz D, Raubenheimer D, Simpson SJ. Protein-leverage in mice: the geometry of macronutrient balancing and consequences for fat deposition. Obesity (Silver Spring) 2008;16: 566571.

9. Simpson SJ, Raubenheimer D. Geometric analysis of macronutrient selection in the rat. Appetite 1997;28:201-213.

10. Felton AM, Felton A, Raubenheimer D, Simpson SJ, Foley WJ, Wood JT, Wallis IR, Lindenmayer DB. Protein content of diets dictates the daily energy intake of a free-ranging primate. Behavioral Ecology 2009;20:685-90.

11. Westerterp-Plantenga 6MS, Wijckmans-Duijsens NE, Verboeket-van de Venne WP, de Graaf K, van het Hof $\mathrm{KH}$, Weststrate JA. Energy intake and body weight effects of six months reduced or full fat diets, as a function of dietary restraint. Int J Obes Relat Metab Disord 1998;22:14-22.

12. Drewnowski A. The real contribution of added sugars and fats to obesity. Epidemiol Rev 2007;29:160-71.

13. Westerterp-Plantenga MS, Rolland V, Wilson SA, Westerterp KR. Satiety related to $24 \mathrm{~h}$ dietinduced thermogenesis during high protein/carbohydrate vs high fat diets measured in a respiration chamber. Eur J Clin Nutr 1999;53:495-502.

14. Weigle DS, Breen PA, Matthys CC, Callahan HS, Meeuws KE, Burden VR, Purnell JQ. A high-protein diet induces sustained reductions in appetite, ad libitum caloric intake, and body weight despite compensatory changes in diurnal plasma leptin and ghrelin concentrations. Am J Clin Nutr 2005;82:41-48.

15. Griffioen-Roose S, Mars M, Siebelink E, Finlayson G, Tome D, de Graaf C. Protein status elicits compensatory changes in food intake and food preferences. Am J Clin Nutr 2012;95:32-38.

16. Gosby AK, Conigrave AD, Lau NS, Iglesias MA, Hall RM, Jebb SA, Brand-Miller J, Caterson ID, Raubenheimer D, Simpson SJ. Testing protein leverage in lean humans: a randomised controlled experimental study. PLoS One 2011;6:e25929.

17. Halton TL, Hu FB. The effects of high protein diets on thermogenesis, satiety and weight loss: a critical review. J Am Coll Nutr 2004;23:373-385.

18. Westerterp-Plantenga MS, Nieuwenhuizen A, Tome D, Soenen S, Westerterp KR. Dietary protein, weight loss, and weight maintenance. Annu Rev Nutr 2009;29:21-41.

19. Lejeune MP, Westerterp KR, Adam TC, Luscombe-Marsh ND, Westerterp-Plantenga MS. Ghrelin and glucagon-like peptide 1 concentrations, 24-h satiety, and energy and substrate metabolism during a high-protein diet and measured in a respiration chamber. Am J Clin Nutr 2006;83:89-94.

20. Westerterp-Plantenga MS, Lejeune MPGM, Smeets AJPG, Luscombe-Marsh ND. Sex differences in energy homeostatis following a diet relatively high in protein exchanged with carbohydrate, assessed in a respiration chamber in humans. Physiology \& Behavior 2009;97:414-419.

21. Stock MJ. Gluttony and thermogenesis revisited. Int J Obes Relat Metab Disord 1999;23:1105-1117. 
22. Veldhorst MA, Nieuwenhuizen AG, Hochstenbach-Waelen A, van Vught AJ, Westerterp KR, Engelen MP, Brummer RJ, Deutz NE, Westerterp-Plantenga MS. Dose-dependent satiating effect of whey relative to casein or soy. Physiol Behav 2009;96:675-682.

23. Veldhorst MA, Nieuwenhuizen AG, Hochstenbach-Waelen A, Westerterp KR, Engelen MP, Brummer RJ, Deutz NE, Westerterp-Plantenga MS. A breakfast with alpha-lactalbumin, gelatin, or gelatin + TRP lowers energy intake at lunch compared with a breakfast with casein, soy, whey, or whey-GMP. Clin Nutr 2009;28:147-155.

24. Veldhorst MA, Nieuwenhuizen AG, Hochstenbach-Waelen A, Westerterp KR, Engelen MP, Brummer RJ, Deutz NE, Westerterp-Plantenga MS. Effects of high and normal soyprotein breakfasts on satiety and subsequent energy intake, including amino acid and 'satiety' hormone responses. Eur J Nutr 2009;48:92-100.

25. Philippaerts RM, Matton L, Wijndaele K, Balduck AL, De Bourdeaudhuij I, Lefevre J. Validity of a physical activity computer questionnaire in 12- to 18-year-old boys and girls. Int J Sports Med 2006;27:131-136.

26. Baecke JA, Burema J, Frijters JE. A short questionnaire for the measurement of habitual physical activity in epidemiological studies. Am J Clin Nutr 1982;36:936-942.

27. Stunkard AJ, Messick S. The three-factor eating questionnaire to measure dietary restraint, disinhibition and hunger. J Psychosom Res 1985;29:71-83.

28. Westerterp-Plantenga MS. Eating behavior in humans, characterized by cumulative food intake curves--a review. Neurosci Biobehav Rev 2000;24:239-248.

29. Tenenbaum G, Furst D, Weingarten G. A statistical reevaluation of the STAI anxiety questionnaire. J Clin Psychol 1985;41:239-244.

30. Edholm OG. Energy balance in man studies carried out by the Division of Human Physiology, National Institute for Medical Research. J Hum Nutr 1977;31:413-431.

31. Vicennati V, Ceroni L, Gagliardi L, Gambineri A, Pasquali R. Comment: response of the hypothalamic-pituitary-adrenocortical axis to high-protein/fat and high-carbohydrate meals in women with different obesity phenotypes. J Clin Endocrinol Metab 2002;87:3984-3988.

32. Sorensen LB, Moller P, Flint A, Martens M, Raben A. Effect of sensory perception of foods on appetite and food intake: a review of studies on humans. Int J Obes Relat Metab Disord 2003;27:1152-1166.

33. Westerterp-Plantenga MS. Fat intake and energy-balance effects. Physiol Behav 2004;83:579-585.

34. Westerterp KR, Verboeket-van de Venne WP, Westerterp-Plantenga MS, Velthuis-te Wierik EJ, de Graaf C, Weststrate JA. Dietary fat and body fat: an intervention study. Int J Obes Relat Metab Disord 1996;20:1022-1026.

35. Westerterp KR. Perception, passive overfeeding and energy metabolism. Physiol Behav 2006;89: 62-65.

36. Harris JA, Benedict FG. A Biometric Study of Human Basal Metabolism. Proc Natl Acad Sci U S A 1918;4:370-373.

37. Westerterp-Plantenga MS, Lejeune MP, Nijs I, van Ooijen M, Kovacs EM. High protein intake sustains weight maintenance after body weight loss in humans. Int J Obes Relat Metab Disord 2004;28:57-64.

38. Pullar JD, Webster AJ. The energy cost of fat and protein deposition in the rat. $\mathrm{Br} J$ Nutr 1977;37:355-363.

39. Murgatroyd PR, Coward WA. An improved method for estimating changes in whole-body fat and protein mass in man. Br J Nutr 1989;62:311-314.

40. Lemmens SG, Martens EA, Born JM, Martens MJ, Westerterp-Plantenga MS. Staggered meal consumption facilitates appetite control without affecting postprandial energy intake. J Nutr 2011;141:482-488.

41. Austin GL, Ogden LG, Hill JO. Trends in carbohydrate, fat, and protein intakes and association with energy intake in normal-weight, overweight, and obese individuals: 1971-2006. Am J Clin Nutr 2011;93:836-843.

42. Leidy HJ, Armstrong CL, Tang M, Mattes RD, Campbell WW. The influence of higher protein intake and greater eating frequency on appetite control in overweight and obese men. Obesity (Silver Spring) 2010;18:1725-1732. 
43. Veldhorst MA, Nieuwenhuizen AG, Hochstenbach-Waelen A, Westerterp KR, Engelen MP, Brummer RJ, Deutz NE, Westerterp-Plantenga MS. Comparison of the effects of a high- and normal-casein breakfast on satiety, 'satiety' hormones, plasma amino acids and subsequent energy intake. $\mathrm{Br} \mathrm{J}$ Nutr 2009;101:295-303.

44. Veldhorst M, Smeets A, Soenen S, Hochstenbach-Waelen A, Hursel R, Diepvens K, Lejeune M, Luscombe-Marsh N, Westerterp-Plantenga M. Protein-induced satiety: effects and mechanisms of different proteins. Physiol Behav 2008;94:300-307.

45. Westerterp-Plantenga MS, Luscombe-Marsh N, Lejeune MPGM, Diepvens K, Nieuwenhuizen A, Engelen MPKJ, Deutz NEP, Azzout-Marniche D, Tome D, Westerterp KR. Dietary protein, metabolism, and body-weight regulation: dose-response effects. International Journal of Obesity 2006;30:S16-S23.

46. Stubbs RJ, Mazlan N, Whybrow S. Carbohydrates, appetite and feeding behavior in humans. J Nutr 2001;131:2775S-2781S.

47. Westerterp-Plantenga MS. Modulatory factors in the effect of energy density on energy intake. $\mathrm{Br} \mathrm{J}$ Nutr 2004;92 Suppl 1:S35-39.

48. Hao S, Sharp JW, Ross-Inta CM, McDaniel BJ, Anthony TG, Wek RC, Cavener DR, McGrath BC, Rudell JB, Koehnle TJ, et al. Uncharged tRNA and sensing of amino acid deficiency in mammalian piriform cortex. Science 2005;307:1776-1778.

49. Gietzen DW, Hao S, Anthony TG. Mechanisms of food intake repression in indispensable amino acid deficiency. Annu Rev Nutr 2007;27:63-78.

50. Maurin AC, Jousse C, Averous J, Parry L, Bruhat A, Cherasse $Y$, Zeng H, Zhang Y, Harding HP, Ron D, et al. The GCN2 kinase biases feeding behavior to maintain amino acid homeostasis in omnivores. Cell Metab 2005;1:273-277.

51. Ross CM, Sharp JW, Gietzen DW. elF2 alpha related signaling of amino acid deficiency in brain areas. Faseb Journal 2004;18:A145-A.

52. Gietzen DW, Rogers QR. Nutritional homeostasis and indispensable amino acid sensing: a new solution to an old puzzle. Trends Neurosci 2006;29:91-99.

53. Aparecida de Franca S, Dos Santos MP, Garofalo MA, Navegantes LC, Kettelhut Ido C, Lopes CF, Kawashita NH. Low protein diet changes the energetic balance and sympathetic activity in brown adipose tissue of growing rats. Nutrition 2009;25:1186-1192.

54. Du F, Higginbotham DA, White BD. Food intake, energy balance and serum leptin concentrations in rats fed low-protein diets. J Nutr 2000;130:514-521.

55. Meyer JH. Interactions of dietary fiber and protein on food intake and body composition of growing rats. Am J Physiol 1958;193:488-494.

56. White BD, Porter $\mathrm{MH}$, Martin PJ. Protein selection, food intake, and body composition in response to the amount of dietary protein. Physiology \& Behavior 2000;69:383-389. 


\section{CHAPTER 4}

Protein leverage effects of beef protein

on energy intake in humans

Martens EA, Tan SY, Dunlop MV, Mattes RD, Westerterp-Plantenga MS Am J Clin Nutr 2014;99:1397-1406 


\section{ABSTRACT}

\section{Background}

The protein leverage hypothesis requires specific evidence that protein intake is regulated more strongly than energy intake.

\section{Objective}

The objective was to determine ad libitum energy intake, body weight changes, appetite profile, and nitrogen balance in response to 3 diets with different protein-to-carbohydrate + fat ratios over 12 consecutive days, with beef as a source of protein.

\section{Design}

A 3-arm, 12-d randomized crossover study was performed in 30 men and 28 women [mean \pm SD age: $33 \pm 16 \mathrm{y}$; body mass index (in $\mathrm{kg} / \mathrm{m}^{2}$ ): $24.4 \pm 4.0$ ] with the use of diets containing $5 \%, 15 \%$, and $30 \%$ of energy (En\%) from protein, predominantly from beef.

\section{Results}

Energy intake was significantly lower in the $30 \mathrm{En} \%$-protein condition $(8.73 \pm 1.93 \mathrm{MJ} / \mathrm{d})$ than in the 5 En\%-protein $(9.48 \pm 1.67 \mathrm{MJ} / \mathrm{d})$ and $15 \mathrm{En} \%$-protein $(9.30 \pm 1.62 \mathrm{MJ} / \mathrm{d})$ conditions $(P=0.001)$, stemming largely from lower energy intake during meals $(P=0.001)$. Hunger $(P=0.001)$ and desire to eat $(P=0.001)$ ratings were higher and fullness ratings were lower $(P=0.001)$ in the 5 En\%-protein condition than in the $15 \mathrm{En} \%$-protein and $30 \mathrm{En} \%$-protein conditions. Nitrogen excretion was lower in the 5 En\%-protein condition $(4.7 \pm 1.5 \mathrm{~g} / 24 \mathrm{~h}$; $P=0.001)$ and was higher in the 30En\%-protein condition $(15.3 \pm 8.7 \mathrm{~g} / 24 \mathrm{~h} ; P=0.001)$ compared with the $15 \mathrm{En} \%$ - protein condition $(10.0 \pm 5.2 \mathrm{~g} / 24 \mathrm{~h})$. Nitrogen balance was maintained in the $5 \mathrm{En} \%$-protein condition and was positive in the $15 \mathrm{En} \%$ - and $30 \mathrm{En} \%$ protein conditions $(P=0.001)$.

\section{Conclusions}

Complete protein leverage did not occur because subjects did not consume to a common protein amount at the expense of energy balance. Individuals did underconsume relative to energy requirements from high-protein diets. The lack of support for protein leverage effects on a low-protein diet may stem from the fact that protein intake was sufficient to maintain nitrogen balance over the $12-d$ trial. This trial was registered at clinicaltrials.gov as NCT01646749. 


\section{INTRODUCTION}

The prevalence of obesity and its associated health problems, such as type 2 diabetes and cardiovascular diseases, has increased to epidemic proportions in a growing number of countries $(1,2)$. Chronic positive energy imbalance is the underlying mechanism. Dietary protein intake has frequently been associated with food intake regulation because of its effects on energy balance (2). According to the protein leverage hypothesis developed by Simpson and Raubenheimer (3), energy intake may be adjusted to maintain protein intake relatively constant. Studies in insects (4), chickens (5), rats (6-8), mice (9), and free-living monkeys (10) suggest that protein intake is regulated more strongly than the intake of carbohydrate and fat. However, it is still unknown whether regulatory mechanisms prioritize the intake of protein over that of carbohydrate, fat, and total energy in humans $(11,12)$.

A dietary intervention study by Weigle et al. (13) showed a sustained decrease in ad libitum energy intake and related weight loss from a high-protein diet [ $30 \%$ of energy (En\%) from protein] compared with a more customary protein diet (15En\% from protein) (13). Furthermore, Griffioen-Roose et al. (14) observed in a 4-d study that subjects increased their protein intake during ad libitum intake after $14 \mathrm{~d}$ of consuming a low-protein diet [0.5 g protein/kg body weight (BW)/d; 5En\%]. They did not replicate the findings of lower intake with a higher protein diet (2.0 g protein/kg BW/d; 21En\%). Results from another short-term metabolic trial showed that subjects consumed, on average, $12 \%$ more energy from a $10 \mathrm{En} \%$ protein diet compared with a diet containing $15 \mathrm{En} \%$ from protein (15). Possible mechanisms for the inverse relation between dietary protein intake and energy intake may be increased and decreased satiation on high- and low-protein diets, respectively, as well as maintenance of nitrogen balance on low-protein diets $(16,17)$.

We carried out a controlled dietary intervention study in which we determined ad libitum energy intake, BW changes, appetite profile, and nitrogen balance in response to diets with protein-to-carbohydrate + fat ratios that were lower than, similar to, and higher than customary diets over 12 consecutive days in a crossover design trial. A recent comparable study evaluated diets containing protein mainly from dairy or plant sources (18). That trial showed that energy intake was lower with a 30En\%-protein diet compared with 5En\%-protein and 15En\%-protein diets (18). Appetite ratings were similar between the 30En\%-protein and the $15 \mathrm{En} \%$ protein diets, indicating that the subjects were similarly satiated by these diets, despite consuming less from the high-protein diet (18). The determination of nitrogen balance is relevant, because a $5 \mathrm{En} \%$-protein diet contains protein well below normal amounts for human populations. Meat protein may have a higher potential than protein from dairy or plant sources to induce a negative energy balance because of its higher potential to increase energy expenditure (19) and a 
possible larger satiating capacity (19), and so may more strongly modify energy relative to protein intake. Therefore, this study was performed with the use of beef protein as the primary protein source.

\section{SUBJECTS AND METHODS}

The Medical Ethical Committees of Maastricht University and Purdue University approved the study, and all participants provided written informed consent. The study was registered at clinicaltrials.gov as NCT01646749.

\section{Study subjects}

Based on the study by Martens et al. (18), power analysis showed that with an $\alpha$ of 0.0167 (significance level for each test: $\alpha=0.05$, taking into account the Bonferroni correction for multiple testing) and a $b$ of 0.10 , at least 56 subjects are needed to show a difference in energy intake between the 30En\%-protein and the $15 \mathrm{En} \%$ protein diets. Seventy-nine subjects were recruited by advertisements in local newspapers and on notice boards at Maastricht University and at Purdue University; 19 of them dropped out because of lack of time. Two subjects were excluded from the data analysis because of noncompliance, as shown by the urinary nitrogen biomarker. Overall, 58 subjects ( 30 men and 28 women) were included in the final data analysis. To cover a wide range of BMIs, subjects were normal weight, overweight or obese [BMI range (in $\mathrm{kg} / \mathrm{m}^{2}$ ): 18.7-38.7]. Ages ranged from 19 to 70 years. BMI and age were equally divided between the male and female groups. Subjects underwent screening that included anthropometric measurements and the completion of questionnaires eliciting information about health, smoking behavior, use of medications, alcohol consumption, physical activity, eating behavior, and liking of the study meals. Subjects were nonsmoking, not using more than moderate amounts of alcohol ( $>10$ drinks/wk), were weight stable (BW change $<3 \mathrm{~kg}$ during the past $6 \mathrm{mo}$ and had no planned weight change during the study period), were not using medication or supplements except for oral contraceptives in women, and rated the taste of the meals as sufficient [visual analog scale (VAS) score for liking: $\geq 50 \mathrm{~mm}$ ] (18).

\section{Study design}

This 2-center study used a crossover design with subjects blinded for the 3 randomly sequenced experimental conditions that differed in relative protein content. Subjects visited the university to consume breakfast, lunch, and dinner ad libitum in the research center for 12 consecutive days in each condition. Previous work indicated that a 12-d time period is sufficient to document a possible effect of the dietary manipulation on BW (20). Subsequent test sessions started $8 \mathrm{wk}$ after 
the start of the preceding test session and included a washout period of 6 wk to minimize carryover and take menstrual cycle phase effects on energy intake in women into account $(21,22)$. Beef protein was used as the main protein source.

\section{Diet composition}

The 3 experimental conditions differed in relative protein content of the meals and snacks, including 5En\%, 15En\%, and 30En\% from protein (Tables 4.1 and 4.2 ). All diets were based on a protein content of $5 \mathrm{En} \%$ from wheat protein, with beef protein providing an additional $10 \mathrm{En} \%$ and $25 \mathrm{En} \%$ to reach the intended protein content of the 15En\%- and 30En\%-protein conditions. Protein was exchanged for carbohydrate to prevent possible effects of palatability and energy density on energy intake (23-25). The resulting protein-to-carbohydrate + fat ratios (En\%) of the diets were 5:95 (low-protein), 15:85 (medium-protein), and 30:70 (highprotein; Tables 4.1 and 4.2).

Table 4.1 Composition of the study diets at Maastricht University

\begin{tabular}{lccc}
\hline \hline & \multicolumn{3}{c}{ Percentage of energy from protein } \\
\cline { 2 - 3 } & $5 \%$ & $15 \%$ & $30 \%$ \\
\hline Breakfast & $5: 95^{1}$ & $15: 85$ & $30: 70$ \\
$\quad$ Protein:carbohydrate + fat (\% of energy) & $7.31 \pm 0.09^{2}$ & $7.24 \pm 0.13$ & $7.37 \pm 0.10$ \\
$\quad$ Energy density (kJ/g) & $5: 95$ & $15: 85$ & $30: 70$ \\
Lunch & $10.97 \pm 1.27$ & $10.75 \pm 1.24$ & $10.83 \pm 1.31$ \\
$\quad$ Protein:carbohydrate + fat (\% of energy) & $5: 95$ & $15: 85$ & $30: 70$ \\
$\quad$ Energy density (kJ/g) & & $5.85 \pm 0.86$ & $5.78 \pm 0.90$ \\
Dinner & & \\
$\quad$ Protein:carbohydrate + fat (\% of energy) & & & \\
Energy density (kJ/g) & & & \\
\hline
\end{tabular}

${ }^{1}$ Mean ratio (all such values); ${ }^{2}$ Mean \pm SD (all such values).

Table 4.2 Composition of the study diets at Purdue University

\begin{tabular}{lccc}
\hline & \multicolumn{3}{c}{ Percentage of energy from protein } \\
\cline { 2 - 4 } & $5 \%$ & $15 \%$ & $30 \%$ \\
\hline Breakfast & & & \\
$\quad$ Protein:carbohydrate + fat (\% of energy) & $6: 94^{1}$ & $15: 85$ & $26: 74$ \\
$\quad$ Energy density (kJ/g) & $18.76 \pm 0.57^{2}$ & $19.89 \pm 0.81$ & $20.47 \pm 1.78$ \\
Lunch & $4: 96$ & $16: 84$ & $30: 70$ \\
$\quad$ Protein:carbohydrate + fat (\% of energy) & $20.89 \pm 1.09$ & $19.01 \pm 0.27$ & $18.83 \pm 0.78$ \\
$\quad$ Energy density (kJ/g) & & $15: 85$ & \\
Dinner & $6: 94$ & $29: 71$ \\
$\quad$ Protein:carbohydrate + fat (\% of energy) & $20.13 \pm 0.52$ & $20.57 \pm 0.87$ & $20.53 \pm 0.65$ \\
$\quad$ Energy density (kJ/g) & &
\end{tabular}

${ }^{1}$ Mean ratio (all such values); ${ }^{2}$ Mean \pm SD (all such values). 
The energy content of the meals was calculated from the nutrition information on the food items and from standard food-composition tables $(26,27)$ and software [Nutrition Data System for Research (in the United States)]. Breakfast was composed of breakfast cereals (Kellogg's Nederland) moistened with orange juice at Maastricht University and of breakfast cereals with diluted milk, breads, and potatoes at Purdue University. At Maastricht University, lunch consisted of bread with vegetable salad, and dinner was composed of pasta with oil, vegetables, and tomato sauce. At Purdue University, lunch consisted of pasta with oil and vegetables, mainly tomatoes. Dinner meals included dairy, vegetable, and pasta combinations with the addition of fruit, salad, and salad dressing. Three different variants for the breakfast cereals, the pasta combinations (pastas, oils, fruits, and vegetables), and the salads served with lunch and dinner were offered in each condition to decrease the possible effects of boredom on energy intake and appetite profile. Palatability was measured by having subjects rate the foods and ensuring they were acceptable before their enrollment.

Food was served as ready-to-eat meals to prevent the selective consumption of food items within meals. Meals were provided ad libitum for $30 \mathrm{~min}$, and subjects were instructed to eat until they felt comfortably full. A fixed amount of $300 \mathrm{ml}$ water per subject was offered with each meal (18).

After each meal, snack items were provided in individual boxes for ad libitum consumption at home. The total energy content of the provided snacks was $\sim 2 \mathrm{MJ} / \mathrm{d}$ in each condition. The total protein content of the snacks differed per condition, in that all snack items were low in protein in the $5 \mathrm{En} \%$-protein condition and contained, on average, $15 \mathrm{En} \%$ or $30 \mathrm{En} \%$ from protein in the medium-protein and high-protein conditions, respectively. Beef was the main protein source of the protein-containing snacks. Two different combinations of several sweet and savory snack items were offered in each condition. Subjects were instructed to bring all leftovers with them during their visit to the research center for the subsequent meal. Subjects were allowed to drink water, tea, and coffee without added milk or sugar, ad libitum between the meals, but no other foods or beverages were allowed to be consumed (18).

\section{Energy and macronutrient intake}

Each meal was weighed to the nearest gram before it was provided to the subjects. Leftovers were reweighed, after which energy and macronutrient intakes were calculated for each subject. The provided snack items were also recorded, and the portions returned uneaten were weighed to determine the energy and macronutrient intake from the snacks per subject. Mean total energy intake was calculated as the sum of energy intake from meals and the energy intake from snacks. Individual daily energy requirements were calculated as the resting metabolic rate calculated with the formula of Harris and Benedict $(28) \times$ the 
physical activity level based on the Baecke Activity Questionnaire or on the 2 validated questions on physical activity at work and during leisure time $(29,30)$.

\section{Appetite profile}

Appetite profile was measured by means of the VASs. These $100-\mathrm{mm}$ scales were anchored with "not at all" at one end and "extremely" at the other end and combined with questions on feelings of hunger, satiety, fullness, thirst, and desire to eat. Subjects were required to complete the VASs before and after breakfast, lunch, and dinner.

\section{Body weight and energy balance}

BW was measured in the fasted state in the morning of days 1, 6, and 12. Energy balance was determined as the difference between energy requirement and energy intake.

\section{Biomarker of protein intake and nitrogen balance}

Nitrogen excretion, measured from 24-h urine collections at baseline (day 0) and at days 5 and 11, was used as an estimate of protein intake. Urine was collected in 2-I urine bottles containing $10 \mathrm{ml}$ of diluted hydrochloric acid $(4 \mathrm{mmol} / \mathrm{l})$ to prevent nitrogen loss through evaporation. Collection started after the first voiding in the morning on the collection days at 8:00h and lasted through the first voiding on the next day at $8: 00 \mathrm{~h}$. The total volume of the 24-h urine was recorded. Urine was gently mixed, and samples were taken and frozen at $-20^{\circ} \mathrm{C}$ until analysis. Nitrogen concentrations were measured with an elemental analyzer [CHN-O-Rapid; Heraeus (in the Netherlands), and Integra COBAS 400 plus; Roche Diagnostics $\mathrm{GmbH}$ in the United States)]. Total nitrogen output was calculated as 24-h urinary nitrogen plus $10 \%$ to account for normal losses via feces and other losses. Nitrogen balance was calculated as the difference between nitrogen excretion and nitrogen intake.

\section{Statistical analysis}

SPSS version 20 for Macintosh OS X (SPSS, Inc) was used to perform statistical analyses. Data are presented as means \pm SDs.

The AUC over the day was calculated for appetite ratings for hunger, fullness, satiety and, desire to eat by using the trapezoidal method. Amplitude scores were calculated for all appetite measures to assess fluctuations over the day. The scores were calculated with the use of VASs, by subtracting the minimum score from the maximum score. Differences in subject characteristics, nitrogen excretion, appetite ratings, energy intake, macronutrient intake, and $\mathrm{BW}$ change between centers were assessed using factorial ANOVA. Factorial ANOVAs with repeated measures were used to test whether nitrogen excretion and nitrogen balance changed over 
time within conditions (5En\%-protein, 15En\%-protein, 30En\%-protein) and to test whether energy and macronutrient intake, appetite ratings, BW change, and nitrogen excretion differed between the diets with various protein-to-carbohydrate + fat ratios. Bonferroni correction for multiple comparisons and post hoc analyses was applied with all ANOVA tests. Pearson's correlation coefficients were used to express the relations between nitrogen excretion and protein intake and between nitrogen balance and energy intake and protein intake within conditions. Differences were regarded as significant if $P<0.05$.

\section{RESULTS}

\section{Subject characteristics}

Subject characteristics are summarized in Table 4.3. Apart from age, which was significantly higher in subjects from Maastricht University than in those from Purdue University, mean subject characteristics did not differ between the centers.

Table $4.3 \quad$ Subject characteristics ${ }^{1}$

\begin{tabular}{lccc}
\hline \hline & Maastricht & Purdue & Total \\
\hline No. of subjects $(\mathrm{M} / \mathrm{F})$ & $28(14 / 14)$ & $30(16 / 14)$ & $58(30 / 28)$ \\
Age $(\mathrm{y})$ & $38 \pm 19^{2, \mathrm{a}}$ & $29 \pm 11^{\mathrm{b}}$ & $33 \pm 16$ \\
Age range $(\mathrm{y})$ & $19-70$ & $19-54$ & $19-70$ \\
Height $(\mathrm{cm})$ & $170.0 \pm 7.1$ & $168.2 \pm 11.7$ & $169.1 \pm 9.7$ \\
BW $(\mathrm{kg})$ & $70.3 \pm 9.8$ & $69.4 \pm 13.6$ & $69.8 \pm 11.8$ \\
$\mathrm{BMI}\left(\mathrm{kg} / \mathrm{m}^{2}\right)$ & $24.2 \pm 2.4$ & $24.7 \pm 5.1$ & $24.4 \pm 4.0$ \\
$\mathrm{BMI}$ range $\left(\mathrm{kg} / \mathrm{m}^{2}\right)$ & $20.0-28.9$ & $18.7-38.7$ & $18.7-38.7$ \\
BMR $(\mathrm{MJ} / \mathrm{d})$ & $6.6 \pm 1.2$ & $6.7 \pm 0.9$ & $6.7 \pm 1.0$ \\
PAL & $1.76 \pm 0.17$ & $1.70 \pm 0.14$ & $1.73 \pm 0.16$ \\
DER $(\mathrm{MJ} / \mathrm{d})$ & $11.7 \pm 2.5$ & $11.4 \pm 1.8$ & $11.5 \pm 2.1$ \\
TFEQ dietary restraint score & $5 \pm 3$ & $6 \pm 4$ & $6 \pm 4$ \\
TFEQ disinhibition score & $4 \pm 2$ & $5 \pm 3$ & $4 \pm 3$ \\
TFEQ hunger score & $5 \pm 3$ & $4 \pm 3$ & $4 \pm 3$ \\
\hline
\end{tabular}

${ }^{1}$ Values with different superscript letters are significantly different, $P<0.05$ (between centers, factorial ANOVA). BMR, basal metabolic rate; BW, body weight; DER, daily energy requirement; PAL, physical activity level; TFEQ, Three-Factor Eating Questionnaire; ${ }^{2}$ Mean \pm SD (all such values).

\section{Energy and macronutrient intake}

Total energy intake was significantly lower in the 30En\%-protein $(8.73 \pm 1.93 \mathrm{MJ} / \mathrm{d})$ than in the $5 \mathrm{En} \%$-protein $(9.48 \pm 1.67 \mathrm{MJ} / \mathrm{d})$ and $15 \mathrm{En} \%$-protein $(9.30 \pm 1.62 \mathrm{MJ} / \mathrm{d})$ conditions ( $P=0.001$; Table 4.4), stemming largely from lower energy intake during meals $(P=0.001)$ but not snacks. The lower mean energy intake from meals in the $30 \mathrm{En} \%$-protein condition, compared with the $15 \mathrm{En} \%$-protein condition, was a result of a lower mean energy intake during lunch $(P=0.001)$ in both centers. In the total 
sample, mean energy intake during breakfast and dinner was comparable between the conditions, whereas energy intake during breakfast was significantly lower in the $30 \mathrm{En} \%$ - protein compared with the $15 \mathrm{En} \%$-protein condition at Maastricht University $(P=0.001)$ and significantly higher in the 5En\%-protein condition compared with the $15 \mathrm{En} \%$-protein condition at Purdue University $(P=0.023)$.

Table 4.4 Mean energy intake, energy balance, and change in BW over $12 \mathrm{~d}$ between conditions in subjects from the Maastricht and Purdue centers separately and combined ${ }^{1}$

\begin{tabular}{|c|c|c|c|}
\hline & Maastricht $(n=28)$ & Purdue $(n=30)$ & Total $(n=58)$ \\
\hline \multicolumn{4}{|l|}{ Energy intake (MJ/d) } \\
\hline \multicolumn{4}{|l|}{ Total } \\
\hline 5 En\% from protein & $8.81 \pm 1.67^{2, a, *}$ & $10.10 \pm 1.43^{b, *}$ & $9.48 \pm 1.67^{*}$ \\
\hline $15 \mathrm{En} \%$ from protein & $8.79 \pm 1.67^{\mathrm{a}, *}$ & $9.76 \pm 1.44^{\mathrm{b}, *}$ & $9.30 \pm 1.62^{*}$ \\
\hline 30 En $\%$ from protein & $7.74 \pm 1.76^{\mathrm{a}, \#}$ & $9.64 \pm 1.62^{\mathrm{b}, *}$ & $8.73 \pm 1.93^{\#}$ \\
\hline \multicolumn{4}{|l|}{ Snacks } \\
\hline 5 En\% from protein & $1.69 \pm 0.53^{a_{, *}}$ & $1.45 \pm 0.56^{\mathrm{a}_{*} *}$ & $1.57 \pm 0.55^{*}$ \\
\hline $15 \mathrm{En} \%$ from protein & $1.39 \pm 0.51^{\mathrm{a}, \#}$ & $1.56 \pm 0.78^{\mathrm{a}, *}$ & $1.48 \pm 0.67^{*}$ \\
\hline $30 \mathrm{En} \%$ from protein & $1.30 \pm 0.46^{\mathrm{a}, \#}$ & $1.61 \pm 0.69^{\mathrm{b}, *}$ & $1.46 \pm 0.61^{*}$ \\
\hline \multicolumn{4}{|l|}{ Meals } \\
\hline 5En\% from protein & $7.11 \pm 1.58^{\mathrm{a}, *}$ & $8.65 \pm 1.21^{\mathrm{b}, *}$ & $7.91 \pm 1.59 *$ \\
\hline $15 \mathrm{En} \%$ from protein & $7.41 \pm 1.67^{\mathrm{a}_{1} *}$ & $8.20 \pm 1.28^{\mathrm{b}, * \#}$ & $7.82 \pm 1.52^{*}$ \\
\hline 30 En\% from protein & $6.44 \pm 1.76^{\mathrm{a}, \#}$ & $8.03 \pm 1.50^{\mathrm{b}, \#}$ & $7.26 \pm 1.80^{\#}$ \\
\hline \multicolumn{4}{|l|}{ Breakfast } \\
\hline 5 En\% from protein & $2.07 \pm 0.69^{a_{1} *}$ & $2.03 \pm 0.30^{\mathrm{a}_{1} *}$ & $2.05 \pm 0.52 *$ \\
\hline $15 \mathrm{En} \%$ from protein & $2.02 \pm 0.59^{\mathrm{a}_{1} *}$ & $1.88 \pm 0.33^{\mathrm{a}, \#}$ & $1.94 \pm 0.47^{*}$ \\
\hline $30 \mathrm{En} \%$ from protein & $1.61 \pm 0.43^{\mathrm{a}, \#}$ & $2.20 \pm 0.35^{\mathrm{b}, *}$ & $1.92 \pm 0.49 *$ \\
\hline \multicolumn{4}{|l|}{ Lunch } \\
\hline 5 En\% from protein & $2.54 \pm 0.86^{a_{, *}}$ & $3.35 \pm 0.55^{\mathrm{b}, *}$ & $2.96 \pm 0.82^{*}$ \\
\hline $15 \mathrm{En} \%$ from protein & $2.60 \pm 0.83^{a_{1} *}$ & $3.06 \pm 0.45^{\mathrm{b}, \#}$ & $2.84 \pm 0.70^{*}$ \\
\hline 30 En\% from protein & $2.25 \pm 0.98^{\mathrm{a}, \#}$ & $2.56 \pm 0.61^{\mathrm{a}, \wedge}$ & $2.41 \pm 0.82^{\#}$ \\
\hline \multicolumn{4}{|l|}{ Dinner } \\
\hline 5 En\% from protein & $2.50 \pm 0.64^{a, *}$ & $3.27 \pm 0.66^{\mathrm{b}, *}$ & $2.90 \pm 0.75^{*}$ \\
\hline $15 \mathrm{En} \%$ from protein & $2.79 \pm 0.68^{\mathrm{a}_{1} *}$ & $3.27 \pm 0.66^{\mathrm{b}, *}$ & $3.04 \pm 0.71 *$ \\
\hline $30 \mathrm{En} \%$ from protein & $2.58 \pm 0.73^{\mathrm{a}, *}$ & $3.27 \pm 0.76^{\mathrm{b}, *}$ & $2.94 \pm 0.81^{*}$ \\
\hline \multicolumn{4}{|l|}{ Energy balance $(\mathrm{MJ} / \mathrm{d})$} \\
\hline 5 En\% from protein & $-2.92 \pm 2.39^{\mathrm{a}, *}$ & $-1.25 \pm 1.87^{\mathrm{b}, *}$ & $-2.06 \pm 2.43^{*}$ \\
\hline $15 \mathrm{En} \%$ from protein & $-2.94 \pm 2.26^{\mathrm{a}, *}$ & $-1.59 \pm 1.71^{\mathrm{b}, *}$ & $-2.24 \pm 2.46^{*}$ \\
\hline $30 \mathrm{En} \%$ from protein & $-3.99 \pm 2.46^{\mathrm{a}, \#}$ & $-1.71 \pm 2.04^{\mathrm{b}, *}$ & $-2.81 \pm 2.63^{\#}$ \\
\hline \multicolumn{4}{|l|}{$\Delta \mathrm{BW}_{\text {day 12-day } 1}(\mathrm{~kg})$} \\
\hline 5 En\% from protein & $-1.3 \pm 1.0^{\mathrm{a}, *}$ & $-0.5 \pm 1.0^{\mathrm{a}, *}$ & $-0.9 \pm 1.1^{*}$ \\
\hline $15 \mathrm{En} \%$ from protein & $-1.3 \pm 0.9^{\mathrm{a}_{3} *}$ & $0.0 \pm 1.2^{a, *}$ & $-0.6 \pm 1.2^{*}$ \\
\hline $30 \mathrm{En} \%$ from protein & $-1.4 \pm 1.3^{\mathrm{a}, *}$ & $-0.4 \pm 0.8^{\mathrm{a}, *}$ & $-0.9 \pm 1.2 *$ \\
\hline
\end{tabular}

1 Values within a row with different superscript letters are significantly different, $P<0.05$ (between centers, factorial ANOVA). Values with different superscript symbols indicate significant differences between diets that differed in relative protein content, $P<0.05$ (at the Maastricht center, at the Purdue center, or at both centers combined, repeated-measures ANOVA with Bonferroni correction for pairwise post-hoc comparisons). BW, body weight; En\%, percentage of energy; $\Delta$, change; ${ }^{2}$ Mean \pm SD (all such values) 
Moreover, a significantly lower mean energy intake from dinner was observed in the 5En\%-protein condition compared with the 15En\%-protein condition $(P=0.018)$ at the Maastricht center. The palatability of the meals was comparable between the conditions. Energy intake from snacks was comparable between the conditions in the total sample of subjects and in those from Purdue University, whereas the intake was significantly higher in the 5En\%-protein-condition at the Maastricht center (Table 4.4). Comparison of the centers showed that total energy intake was significantly higher in all conditions at Purdue University than at Maastricht University, despite similar energy requirements.

Mean protein intake over $12 \mathrm{~d}$ varied directly according to the amount of protein in the diet $(P=0.001$; Table 4.5$)$. Mean protein intake was below the "protein requirement" in the 5En\%-protein condition and above protein requirements in the $15 \mathrm{En} \%$ - and 30En\%-protein conditions (Table 4.5). Mean carbohydrate intake was significantly different between the conditions $(P=0.001$; Table 4.5), with the highest intake in the 5En\%-protein condition and the lowest intake in the $30 \mathrm{En} \%$-protein condition. Fat intake was significantly lower in the 30 En\%-protein condition compared with the 5En\%-protein $(P=0.001)$ and $15 \mathrm{En} \%$ protein $(P=0.001)$ conditions (Table 4.5$)$. Daily energy and protein intake did not significantly change over the $12-d$ test periods in each condition. An increase in protein-to-carbohydrate + fat ratio of the diet resulted in significant underconsumption relative to energy requirements $(P=0.001)$, whereas a decrease in protein-to-carbohydrate + fat ratio did not significantly affect energy intake (Table 4.4, Figure 4.1). Men consumed more energy than did women, but sex did not have an effect on differences in energy and macronutrient intake between conditions.

\section{Appetite profile}

The consumption of the meals elicited significant decreases in mean ratings of hunger and desire to eat and significant increases in mean ratings of fullness in all conditions over the 12-d test periods $(P=0.001)$. Mean AUC over the 12-d test periods was significantly higher for appetite ratings of hunger $(P=0.001)$ and desire to eat $(P=0.001)$ and significantly lower for fullness $(P=0.001)$ in the 5 En\%-protein compared with the 15En\%-protein condition (see Supplemental Table S4.1 under "Supplemental data" in the online issue). Despite significant differences in energy intake, appetite ratings of hunger and of fullness were comparable between the conditions and that of desire to eat was significantly lower in the 30En\%-protein condition than in the 15En\%-protein condition, expressed as mean AUC over the 12-d test periods (see Supplemental Table S4.1 under "Supplemental data" in the online issue). Amplitude scores did not significantly differ between the conditions. 
Table 4.5 Mean macronutrient intakes and ratios of protein-to-carbohydrate + fat over $12 \mathrm{~d}$ between conditions in subjects from the Maastricht and Purdue centers separately and combined $^{1}$

\begin{tabular}{|c|c|c|c|}
\hline & Maastricht $(n=28)$ & Purdue $(n=30)$ & Total $(n=58)$ \\
\hline \multicolumn{4}{|l|}{ Protein intake } \\
\hline \multicolumn{4}{|c|}{$5 E n \%$ from protein } \\
\hline$(\mathrm{MJ} / \mathrm{d})$ & $0.43 \pm 0.09^{2, a, *}$ & $0.59 \pm 0.08^{\mathrm{b}, *}$ & $0.51 \pm 0.01 *$ \\
\hline$(\mathrm{g} / \mathrm{kg} \mathrm{BW} / \mathrm{d})$ & $0.4 \pm 0.1^{a, *}$ & $0.5 \pm 0.1^{\mathrm{b}, *}$ & $0.4 \pm 0.1^{*}$ \\
\hline \multicolumn{4}{|c|}{$15 E n \%$ from protein } \\
\hline$(\mathrm{MJ} / \mathrm{d})$ & $1.25 \pm 0.29^{\mathrm{a}, \#}$ & $1.46 \pm 0.26^{\mathrm{b}, \#}$ & $1.36 \pm 0.29^{\#}$ \\
\hline (g/kg BW/d) & $1.1 \pm 0.2^{\mathrm{a}, \#}$ & $1.3 \pm 0.3^{\mathrm{b}, \#}$ & $1.2 \pm 0.3^{\#}$ \\
\hline \multicolumn{4}{|c|}{30 En $\%$ from protein } \\
\hline$(\mathrm{MJ} / \mathrm{d})$ & $2.08 \pm 0.61^{a, \wedge}$ & $2.41 \pm 0.50^{\mathrm{b}, \wedge}$ & $2.25 \pm 0.57^{\wedge}$ \\
\hline (g/kg BW/d) & $1.8 \pm 0.5^{\mathrm{a},^{\wedge}}$ & $2.1 \pm 0.5^{\mathrm{b}, \wedge}$ & $2.0 \pm 0.5^{\wedge}$ \\
\hline \multicolumn{4}{|c|}{ Carbohydrate intake } \\
\hline \multicolumn{4}{|c|}{5 En\% from protein } \\
\hline$(\mathrm{MJ} / \mathrm{d})$ & $5.11 \pm 1.03^{\mathrm{a}, *}$ & $6.37 \pm 1.02^{\mathrm{b}, *}$ & $5.76 \pm 1.20^{*}$ \\
\hline (g/kg BW/d) & $4.4 \pm 0.9^{a_{,} *}$ & $5.5 \pm 1.0^{\mathrm{b}, *}$ & $5.0 \pm 1.1^{*}$ \\
\hline \multicolumn{4}{|c|}{$15 E n \%$ from protein } \\
\hline$(\mathrm{MJ} / \mathrm{d})$ & $4.33 \pm 0.79^{\mathrm{a}, \#}$ & $5.25 \pm 0.77^{b, \#}$ & $4.81 \pm 0.90^{\#}$ \\
\hline (g/kg BW/d) & $3.7 \pm 0.7^{\mathrm{a}, \#}$ & $4.6 \pm 0.9^{\mathrm{b}, \#}$ & $4.2 \pm 0.9^{\#}$ \\
\hline \multicolumn{4}{|c|}{$30 E n \%$ from protein } \\
\hline$(\mathrm{MJ} / \mathrm{d})$ & $2.92 \pm 0.56^{\mathrm{a}, \wedge}$ & $4.28 \pm 0.65^{b, \wedge}$ & $3.62 \pm 0.92^{\wedge}$ \\
\hline (g/kg BW/d) & $2.5 \pm 0.6^{\mathrm{a}, \wedge}$ & $3.8 \pm 0.7^{b, \wedge}$ & $3.2 \pm 0.9^{\wedge}$ \\
\hline \multicolumn{4}{|l|}{ Fat intake } \\
\hline \multicolumn{4}{|c|}{$5 E n \%$ from protein } \\
\hline$(\mathrm{MJ} / \mathrm{d})$ & $3.27 \pm 0.60^{\mathrm{a}, *}$ & $3.18 \pm 0.44^{a_{,} *}$ & $3.23 \pm 0.52 *$ \\
\hline (g/kg BW/d) & $1.2 \pm 0.2^{\mathrm{a}, *}$ & $1.2 \pm 0.2^{\mathrm{a}, *}$ & $1.2 \pm 0.2^{*}$ \\
\hline \multicolumn{4}{|c|}{$15 E n \%$ from protein } \\
\hline$(\mathrm{MJ} / \mathrm{d})$ & $3.22 \pm 0.64^{\mathrm{a}, *}$ & $3.05 \pm 0.50^{a, *^{\#}}$ & $3.13 \pm 0.57^{*}$ \\
\hline (g/kg BW/d) & $1.2 \pm 0.2^{\mathrm{a}, *}$ & $1.2 \pm 0.3^{\mathrm{a}, *}$ & $1.2 \pm 0.3^{*}$ \\
\hline \multicolumn{4}{|c|}{$30 E n \%$ from protein } \\
\hline$(\mathrm{MJ} / \mathrm{d})$ & $2.75 \pm 0.66^{\mathrm{a}, \#}$ & $2.95 \pm 0.56^{b, \#}$ & $2.85 \pm 0.61^{\#}$ \\
\hline (g/kg BW/d) & $1.0 \pm 0.3^{\mathrm{a}, \#}$ & $1.2 \pm 0.2^{b, *}$ & $1.1 \pm 0.3^{\#}$ \\
\hline \multicolumn{4}{|c|}{ Protein:carbohydrate + fat (En\%) } \\
\hline \multicolumn{4}{|c|}{$5 E n \%$ from protein } \\
\hline Meals & $5: 95^{3}$ & $5: 95$ & 5:95 \\
\hline Total & 5:95 & $6: 94$ & 5:95 \\
\hline \multicolumn{4}{|c|}{$15 E n \%$ from protein } \\
\hline Meals & $15: 85$ & $15: 85$ & $15: 85$ \\
\hline Total & $14: 86$ & $15: 85$ & $15: 85$ \\
\hline \multicolumn{4}{|c|}{$30 E n \%$ from protein } \\
\hline Meals & $30: 70$ & $30: 70$ & $30: 70$ \\
\hline Total & $27: 73$ & $25: 75$ & $26: 74$ \\
\hline
\end{tabular}

${ }^{1}$ Values within a row with different superscript letters are significantly different, $P<0.05$ (between centers, factorial ANOVA). Values with different superscript symbols indicate significant differences between diets that differed in relative protein content, $P<0.05$ (at the Maastricht center, at the Purdue center, or at both centers combined, repeated-measures ANOVA with Bonferroni correction for pairwise post-hoc comparisons). BW, body weight; En\%, percentage of energy; ${ }^{2}$ Mean \pm SD (all such values); ${ }^{3}$ Mean ratio (all such values). 


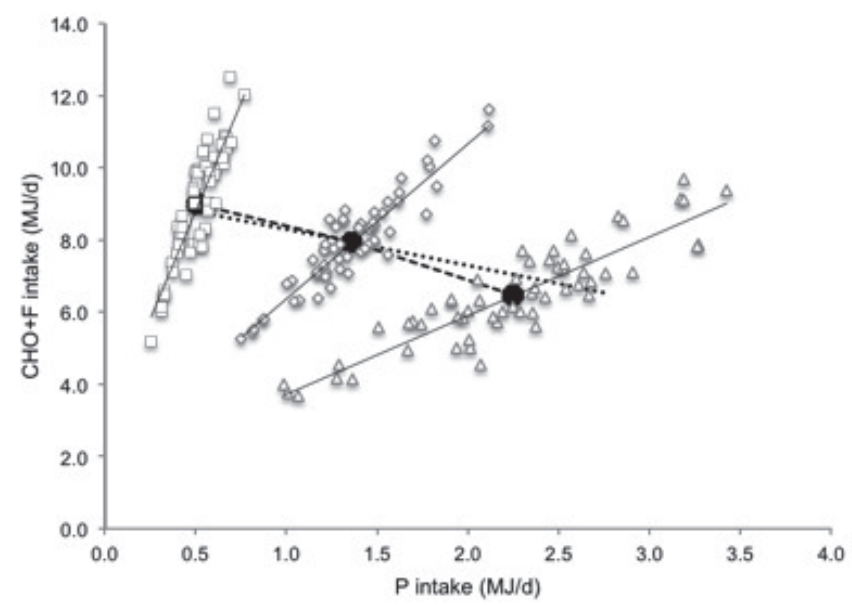

Figure 4.1 Relation between mean protein intake and mean carbohydrate + fat intake in response to diets differing in protein-to-carbohydrate + fat ratio for $12 \mathrm{~d}(n=58)$. Between-subject effects are expressed as individual means for the 5En\%-protein condition (white squares), the 15En\%-protein condition (white diamonds), and the 30En\%-protein condition (white triangles); within-subject effects are expressed as group means (black circles). The dashed line combines group means, and the dotted line respresents intakes of protein and carbohydrate + fat that may occur if intakes were regulated to energy intake in the $15 \mathrm{En} \%$ protein condition. The differences between the dashed line and the dotted line show the degree to which carbohydrate + fat intake is balanced against protein intake. $\mathrm{CHO}$, carbohydrate; En\%, percentage of energy; F, fat; $\mathrm{P}$, protein.

\section{BW and energy balance}

During the test periods, mean BW decreased from day 1 to day 12 in all conditions $(P=0.001)$, except for the 15En\%-protein condition at Purdue University (Table 4.4). The decrease in BW did not differ between conditions. Subjects consistently regained their original BW before the subsequent test session started. Mean energy deficit was significantly greater in the $30 \mathrm{En} \%$-protein condition compared with the 15En\%-protein condition (Table 4.4).

\section{Biomarker of protein intake and nitrogen balance}

Baseline nitrogen excretion did not differ significantly between the 5En\%protein $(9.0 \pm 3.4 \mathrm{~g} / 24 \mathrm{~h}), 15 \mathrm{En} \%$-protein $(10.0 \pm 5.2 \mathrm{~g} / 24 \mathrm{~h})$ and $30 \mathrm{En} \%$-protein $(9.9 \pm 3.9 \mathrm{~g} / 24 \mathrm{~h})$ conditions and indicated that subjects had normal protein intakes at the start of each test period (see Supplemental Table 2 under "Supplemental data" in the online issue). At days 5 and 11, nitrogen excretion was significantly lower in the $5 \mathrm{En} \%$-protein condition $(5.5 \pm 2.4$ and $4.7 \pm 1.5 \mathrm{~g} / 24 \mathrm{~h}$, respectively; $P=0.001)$ and was higher in the 30En\%-protein condition (14.8 \pm 7.4 and $15.3 \pm 8.7$ $\mathrm{g} / 24 \mathrm{~h}$, respectively; $P=0.001$ ) compared with baseline (see Supplemental Table $\mathrm{S} 4.2$ 
under "Supplemental data" in the online issue). In the 15En\%-protein condition, nitrogen excretion did not change significantly from baseline throughout the test period. Nitrogen excretion differed significantly between the conditions, thereby confirming significant differences in protein intake between conditions $(P=0.001)$. In each condition, no significant differences between the urine collection days 5 and 11 were observed, which indicates stable protein intakes within the conditions over the 12-d test periods. Urinary nitrogen excretion was significantly correlated with the measured protein intake in the 15En\%- and 30En\%-protein conditions $(r=0.277$ and 0.348 , respectively; $P<0.05)$, whereas this correlation was not significant for the $5 \mathrm{En} \%$-protein condition. Nitrogen balance did not significantly differ from zero in the $5 \mathrm{En} \%$-protein condition and was positive in the $15 \mathrm{En} \%$ - and 30 En\%-protein conditions $(P=0.001)$. Nitrogen balance correlated significantly with daily energy intake (5En\%-protein, $r=0.522$; 15En\%-protein, $r=0.372$; 30En\%protein, $r=0.364 ; P<0.05$ ) and protein intake (5En\%-protein, $r=0.673 ; 15 \mathrm{En} \%$ protein, $r=0.593$; 30En\%-protein, $r=0.534 ; P=0.001$ ) in all conditions (Figure 4.2).

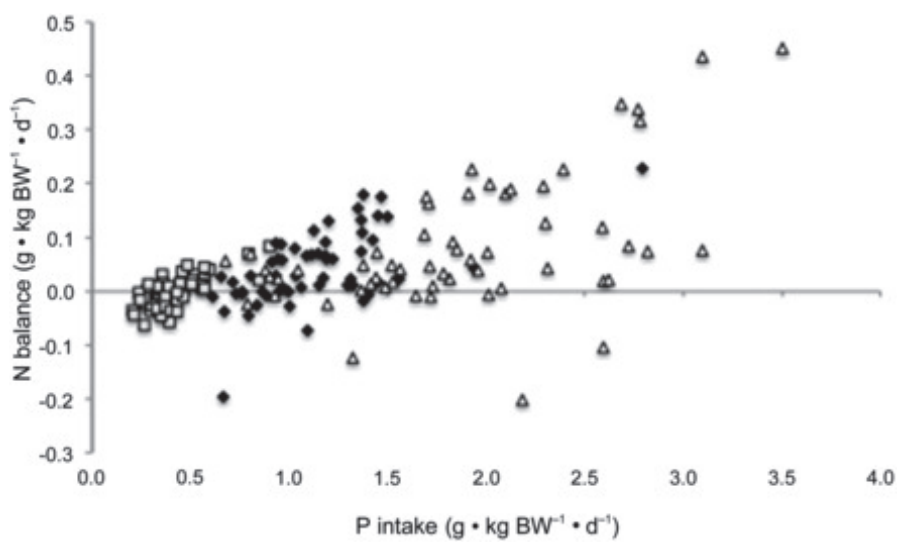

Figure 4.2 Relation between mean protein intake and mean nitrogen balance at day 11 in response to diets differing in protein-to-carbohydrate + fat ratio $(n=58)$. Between-subject effects for the 5En\%-protein condition (white squares), the 15En\%-protein condition (black diamonds), and the 30En\%-protein condition (white triangles). $P<0.05$ (Pearson's correlation coefficient) for all conditions. BW, body weight; En\%, percentage of energy; $N$, nitrogen; $P$, protein.

\section{DISCUSSION}

The protein leverage hypothesis requires specific evidence that protein intake is regulated more strongly than energy intake. This study did not show complete protein leverage because subjects did not consume to a common protein amount at the expense of energy balance. Individuals did underconsume relative to energy 
requirements, predominantly from meals comprising diets that contained a higher protein-to-carbohydrate + fat ratio. No evidence for protein leverage effects from diets containing a lower ratio of protein-to-carbohydrate + fat was obtained. The successful implementation of the dietary protein intervention on each arm of the trial was confirmed by urinary nitrogen concentrations. Nitrogen excretion was lower in the 5En\%-protein condition and was higher in the 30En\%-protein condition compared with the $15 \mathrm{En} \%$-protein condition. Nitrogen balance was maintained in the $5 \mathrm{En} \%$-protein condition and was positive in the $15 \mathrm{En} \%$ - and $30 \mathrm{En} \%$-protein conditions.

The meals at Maastricht University were consistently of lower energy content than the Purdue meals, and this likely stemmed from the lower-energy-density meals at Maastricht. The difference in energy density was attributable to the use of more liquid in the recipes at Maastricht University (eg, with the breakfast cereals and with the sauces served with dinner). However, energy density was consistent across diets within a study center. The consistency of findings on energy intake across centers suggests that energy density was not a critical determinant of responses.

BW loss did not differ between the protein diets, despite mean energy balance being more negative after the 30En\%-protein diet compared with the 5En\%- and $15 \mathrm{En} \%$-protein diets. This may be a result of a possible fat-free mass-sparing effect from the high-protein diet (31). Although the duration of the test periods was sufficient to measure differences in BW change, it was not long enough to reliably measure differences in body composition $(24,32)$. The observed decrease in BW was likely the result of daily structure with fixed and regular meal times imposed by the study design.

Protein intake must still fall within a certain range to ensure it addresses possible shortages or excesses $(18,33,34)$. Humans have a wide capacity to respond and adapt to differences in protein intake (35). However, the limits of such adaptation to a protein challenge acutely and over the long term remain to be clarified. The basis for apparently stronger protein leveraging responses in various animal models (4-9) than in humans is unclear. Possibilities for species differences may reflect abilities to maintain protein intake for growth and reproduction on lowprotein diets and/or limitations on metabolism of excess protein from high-protein diets.

To provide supporting evidence for the protein leverage hypothesis in humans, it is necessary to show direct effects on energy intake from relatively low-protein and relatively high-protein diets. Only 2 preceding studies have applied such a design to test the protein leverage hypothesis experimentally $(15,18)$. Similar to the results of the present study, these trials observed trends only in one direction, either a higher energy intake with a 10En\%-protein diet (15) or a lower energy intake with a $30 \mathrm{En} \%$-protein diet (18). None of the trials observed changes in energy intake in both conditions relative to a diet containing $15 \mathrm{En} \%$ from protein. 
In a recent review, Gosby et al. (36) argued that protein intake is prioritized over the intake of carbohydrate and fat and over total energy intake. They reported an inverse relation between energy intake and dietary protein content with a dietary protein range between 10 and $20 \mathrm{En} \%$, with less convincing findings noted the more extreme protein intakes. However, the less consistent findings were drawn from shorter trials where it is likely that subjects were not in energy balance or from less well controlled trials in subjects in free-living situations. Thus, conclusions must be drawn with caution. The authors argued that diets containing $<10 \%$ En from protein may be so extreme as to preclude a compensatory dietary response. The primary approach to test the lower limits of protein intake has been to assess effects of a lack of indispensible amino acids. The detection of reduced concentrations of indispensable amino acids in the brain affects protein synthesis, subsequently leading to behavioral responses including underconsumption of diets that lack a minimal amount of indispensable amino acids (37-40). Nitrogen balance studies are commonly applied to evaluate the degree to which protein intake compensates for obligatory losses of nitrogen from several pathways including amino acid breakdown $(41,42)$. Tomé $(43)$ and Tomé and Bos (44) determined that minimum nitrogen losses are $\sim 54 \mathrm{mg} / \mathrm{kg} \mathrm{BW} / \mathrm{d}$, which would have corresponded to a protein intake of $24 \mathrm{~g} / \mathrm{d}$ in our study. The measured protein intake of $31 \mathrm{~g} / \mathrm{d}$ in our study corresponds to $0.4 \mathrm{~g} / \mathrm{kg}$ BW/d when considering a mean BW of $69.8 \mathrm{~kg}$. Because the efficiency of dietary protein utilization needs to be taken into account, a low-protein diet of $5 \mathrm{En} \%$ from protein would be too low in protein to sustain long-term health. Observations from studies in developing countries show health deterioration related to low protein intake, especially of indispensible amino acids, at intakes $<0.66 \mathrm{~g} / \mathrm{kg} \mathrm{BW} / \mathrm{d}(45)$. However, one of the findings of our study was that nitrogen balance was maintained over $12 \mathrm{~d}$ during ad libitum consumption of the 5 En\%-protein diet. Protein intake being below the assumed protein requirement was not a trigger to increase energy intake over the 12-d study period. Subjects would have needed to consume $0.92-2.3 \mathrm{~kg}$ food/d more with the $5 \mathrm{En} \%$-protein diet than they did with the $15 \mathrm{En} \%$-protein diet to fully offset the protein dilution. With higher energy densities this is feasible, yet with lower energy densities this becomes difficult (46). However, it is not proposed that a diet containing $5 \%$ En is sustainable; it was implemented only to test the protein leverage hypothesis. Other experimental studies have reported positive energy balance with diets containing as low as $3-5 \mathrm{En} \%$ from protein $(47,48)$. These data suggest that the lower concentration of protein provided in the present trial was not outside the range that is feasible to test protein leveraging. Although we are aware that no clear recommendation exists that defines the safe upper limit of protein intake, intake up to $1.66 \mathrm{~g} / \mathrm{kg} \mathrm{BW} / \mathrm{d}$ was not associated with increased health risks $(41,45)$. In our study, protein intake during the high-protein diet interventions was below this amount of intake and could hence be considered safe. 
The positive nitrogen balance as observed on the high-protein diet corresponds with earlier observations. Fuller and Garlick (49) measured the long-term effects of a change in protein intake and reported a persistent positive nitrogen balance over $40 \mathrm{~d}$ after a change from a normal to a high protein intake. A possible explanation might be a transient retention or loss of body nitrogen because of a labile pool of body nitrogen (50). Conversely, there is concern that overeating is facilitated by a high-carbohydrate, high-fat diet $(23-25,46,51)$. More research is necessary to establish a cause-and-effect relation by taking all macronutrients into account. In the current study, the high carbohydrate content of the low-protein diet did not cause overeating. Subjects reported more hunger and desire to eat and less fullness with the $5 \mathrm{En} \%$-protein diet than with the $15 \mathrm{En} \%$-protein diet. The low fullness value of the $5 \mathrm{En} \%$ diet was a stimulus for increased energy intake between meals in the Maastricht sample but not at Purdue. It remains to be determined whether overeating with a relatively low-protein diet stems from its high-fat content.

Subjects consumed less food during the 30En\%-protein diet relative to baseline. This occurred with appetite scores comparable to those elicited by a $15 \mathrm{En} \%$-protein diet. These findings support previous evidence that, under some conditions, highprotein diets have strong satiety effects and result in a lower energy intake $(13,16-18,52-57)$. The strengths of the present study were its 2-center study design with the same protocols and the tight control over energy and macronutrient intake over a period of $12 \mathrm{~d}$, in a large number of subjects, including both sexes.

In conclusion, complete protein leverage did not occur because subjects did not consume to a common protein amount at the expense of energy balance. Individuals did underconsume relative to energy requirements from high-protein diets. The lack of support for protein leverage effects on low-protein diets may stem from the fact that protein intake was sufficient to maintain nitrogen balance over $12 \mathrm{~d}$; thus, there was still a low drive to adjust energy intake to meet some optimal protein intake level.

\section{ACKNOWLEDGEMENTS}

We thank the subjects for their participation in the study and Lianne Verlinden, Floor van den Brand, Angelique van Sambeek, Maud Koolen, Nina ter Horst, Imco Janssen, Judy George, Robin Rhine, Chelsey Keeler, Maria Alexandrova, and Amy Wright for their help with the practical work. Nitrogen analyses were performed by Hasibe Aydeniz. 


\section{SUPPLEMENTAL TABLES}

Table S4.1 Appetite profile over $12 \mathrm{~d}$ between conditions in subjects from the Maastricht and Purdue centers separately and combined ${ }^{1}$

\begin{tabular}{lccc}
\hline \hline & Maastricht $(n=28)$ & Purdue $(n=30)$ & Total $(n=58)$ \\
\hline Hunger (mmVAS/24h) & & & \\
5En\% from protein & $24466 \pm 2417^{2, \mathrm{a}, *}$ & $19066 \pm 6573^{\mathrm{b}, *}$ & $21673 \pm 5671^{*}$ \\
15En\% from protein & $23226 \pm 2081^{\mathrm{a}, \#}$ & $15703 \pm 4929^{\mathrm{b}, \#}$ & $19335 \pm 5366^{\#}$ \\
30En\% from protein & $22413 \pm 3045^{\mathrm{a}, \#}$ & $14715 \pm 5124^{\mathrm{b}, \#}$ & $18432 \pm 5728^{\#}$ \\
Fullness (mmVAS/24h) & & & \\
5En\% from protein & $25597 \pm 2331^{\mathrm{a}, *}$ & $21696 \pm 7017^{\mathrm{b}, *}$ & $23579 \pm 5612^{*}$ \\
15En\% from protein & $27285 \pm 2618^{\mathrm{a}, \#}$ & $25309 \pm 7502^{\mathrm{a}, \#}$ & $26263 \pm 5734^{\#}$ \\
30En\% from protein & $28397 \pm 3750^{\mathrm{a}, \#}$ & $25065 \pm 9294^{\mathrm{a}, \#}$ & $26674 \pm 7309^{\#}$ \\
Desire to eat (mmVAS/24h) & & & \\
5En\% from protein & $24781 \pm 3131^{\mathrm{a}, *}$ & $18648 \pm 7414^{\mathrm{b}, *}$ & $21608 \pm 6493^{*}$ \\
15En\% from protein & $23560 \pm 2228^{\mathrm{a}, * \#}$ & $15057 \pm 4727^{\mathrm{b}, \#}$ & $19162 \pm 5664^{\#}$ \\
30En\% from protein & $22460 \pm 3146^{\mathrm{a}, \#}$ & $14016 \pm 5537^{\mathrm{b}, \#}$ & $18093 \pm 6197^{\wedge}$ \\
\hline
\end{tabular}

1 Values within a row with different superscript letters are significantly different, $P<0.05$ (between centers, factorial ANOVA). Values with different superscript symbols indicate significant differences between diets that differed in relative protein content, $P<0.05$ (at the Maastricht center, at the Purdue center, or at both centers combined, repeated-measures ANOVA with Bonferroni correction for pairwise post-hoc comparisons). En\%, percentage of energy; VAS, visual analog scale; ${ }^{2}$ Mean \pm SD (all such values).

Table S4.2 Urinary nitrogen excretion ( $\mathrm{g} / 24 \mathrm{~h}$ ) at baseline (day 0 ) and at days 5 and 11 between conditions in subjects from the Maastricht and Purdue centers separately and combined ${ }^{1}$

\begin{tabular}{|c|c|c|c|}
\hline & Maastricht $(n=28)$ & Purdue $(n=30)$ & Total $(n=58)$ \\
\hline \multicolumn{4}{|c|}{$5 \mathrm{En} \%$ from protein } \\
\hline Day 0 & $10.1 \pm 3.4^{2, a, *}$ & $8.0 \pm 3.1^{b, *}$ & $9.0 \pm 3.4^{*}$ \\
\hline Day 5 & $5.7 \pm 1.8^{\mathrm{a}, \#}$ & $5.2 \pm 2.9^{\mathrm{a}, \#}$ & $5.5 \pm 2.4^{\#}$ \\
\hline Day 11 & $4.9 \pm 1.6^{\mathrm{a}, \#}$ & $4.4 \pm 1.5^{\mathrm{a}, \#}$ & $4.7 \pm 1.5^{\#}$ \\
\hline \multicolumn{4}{|c|}{$15 \mathrm{En} \%$ from protein } \\
\hline Day 0 & $10.5 \pm 3.4^{a, *}$ & $9.5 \pm 6.5^{\mathrm{a}, *}$ & $10.0 \pm 5.2^{*}$ \\
\hline Day 5 & $9.3 \pm 2.7^{\mathrm{a}, *}$ & $8.2 \pm 2.8^{\mathrm{a}, *}$ & $8.7 \pm 2.8^{*}$ \\
\hline Day 11 & $10.0 \pm 2.8^{\mathrm{a}, *}$ & $9.1 \pm 4.4^{\mathrm{a}, *}$ & $9.6 \pm 4.0^{*}$ \\
\hline \multicolumn{4}{|c|}{30 En\% from protein } \\
\hline Day 0 & $10.5 \pm 3.2^{\mathrm{a}, *}$ & $9.2 \pm 4.4^{\mathrm{a}, *}$ & $9.9 \pm 3.9 *$ \\
\hline Day 5 & $14.5 \pm 5.6^{\mathrm{a}, \#}$ & $15.1 \pm 8.8^{\mathrm{a}, \#}$ & $14.8 \pm 7.4^{\#}$ \\
\hline Day 11 & $14.8 \pm 6.0^{\mathrm{a}, \#}$ & $15.7 \pm 10.7^{\mathrm{a}, \#}$ & $15.3 \pm 8.7^{\#}$ \\
\hline
\end{tabular}

1 Values within a row with different superscript letters are significantly different, $P<0.05$ (between centers, factorial ANOVA). Values with different superscript symbols indicate significant differences between diets that differed in relative protein content, $P<0.05$ (at the Maastricht center, at the Purdue center, or at both centers combined, repeated-measures ANOVA with Bonferroni correction for pairwise post-hoc comparisons). En\%, percentage of energy; ${ }^{2}$ Mean \pm SD (all such values). 


\section{REFERENCES}

1. World Health Organization. Obesity and overweight. Fact sheet $\mathrm{N}^{\circ} 311$. Updated March 2013. Internet: http://www.who.int/mediacentre/factsheets/fs311/en/ (assessed 13 May 2014).

2. Abete I, Astrup A, Martinez JA, Thorsdottir I, Zulet MA. Obesity and the metabolic syndrome: role of different dietary macronutrient distribution patterns and specific nutritional components on weight loss and maintenance. Nutr Rev 2010;68:214-231.

3. Simpson SJ, Raubenheimer D. Obesity: the protein leverage hypothesis. Obes Rev 2005;6:133-142.

4. Raubenheimer D, Simpson SJ. Integrative models of nutrient balancing: application to insects and vertebrates. Nutr Res Rev 1997;10:151-179.

5. Shariatmadari F, Forbes JM. Growth and food intake responses to diets of different protein contents and a choice between diets containing two concentrations of protein in broiler and layer strains of chicken. Br Poult Sci 1993;34:959-970.

6. Tews JK, Repa JJ, Harper AE. Protein selection by rats adapted to high or moderately low levels of dietary protein. Physiol Behav 1992;51:699-712.

7. Theall CL, Wurtman JJ, Wurtman RJ. Self-selection and regulation of protein: carbohydrate ratio in foods adult rats eat. J Nutr 1984;114:711-718.

8. Simpson SJ, Raubenheimer D. Geometric analysis of macronutrient selection in the rat. Appetite 1997;28:201-213.

9. Sorensen A, Mayntz D, Raubenheimer D, Simpson SJ. Protein-leverage in mice: the geometry of macronutrient balancing and consequences for fat deposition. Obesity (Silver Spring) 2008;16:566-571.

10. Felton AM, Felton A, Raubenheimer D, Simpson SJ, Foley WJ, Wood JT, Wallis IR, Lindenmayer DB. Protein content of diets dictates the daily energy intake of a free-ranging primate. Behavioral Ecology 2009;20:685-690.

11. Westerterp-Plantenga MS, Wijckmans-Duijsens NE, Verboeket-van de Venne WP, de Graaf K, van het Hof $\mathrm{KH}$, Weststrate JA. Energy intake and body weight effects of six months reduced or full fat diets, as a function of dietary restraint. Int J Obes Relat Metab Disord 1998;22:14-22.

12. Drewnowski A. The real contribution of added sugars and fats to obesity. Epidemiol Rev 2007;29:160-171.

13. Weigle DS, Breen PA, Matthys CC, Callahan HS, Meeuws KE, Burden VR, Purnell JQ. A high-protein diet induces sustained reductions in appetite, ad libitum caloric intake, and body weight despite compensatory changes in diurnal plasma leptin and ghrelin concentrations. Am J Clin Nutr 2005;82:41-48.

14. Griffioen-Roose S, Mars M, Siebelink E, Finlayson G, Tome D, de Graaf C. Protein status elicits compensatory changes in food intake and food preferences. Am J Clin Nutr 2012;95:32-38.

15. Gosby AK, Conigrave AD, Lau NS, Iglesias MA, Hall RM, Jebb SA, Brand-Miller J, Caterson ID, Raubenheimer D, Simpson SJ. Testing protein leverage in lean humans: a randomised controlled experimental study. PLoS One 2011;6:e25929.

16. Halton TL, Hu FB. The effects of high protein diets on thermogenesis, satiety and weight loss: a critical review. J Am Coll Nutr 2004;23:373-385.

17. Westerterp-Plantenga MS, Nieuwenhuizen A, Tome D, Soenen S, Westerterp KR. Dietary protein, weight loss, and weight maintenance. Annu Rev Nutr 2009;29:21-41.

18. Martens EA, Lemmens SG, Westerterp-Plantenga MS. Protein leverage affects energy intake of high-protein diets in humans. Am J Clin Nutr 2013;97:86-93.

19. Mikkelsen PB, Toubro S, Astrup A. Effect of fat-reduced diets on 24-h energy expenditure: comparisons between animal protein, vegetable protein, and carbohydrate. Am J Clin Nutr 2000;72:1135-1141.

20. Edholm OG. Energy balance in man studies carried out by the Division of Human Physiology, National Institute for Medical Research. J Hum Nutr 1977;31:413-431.

21. Vicennati V, Ceroni L, Gagliardi L, Gambineri A, Pasquali R. Comment: response of the hypothalamic-pituitary-adrenocortical axis to high-protein/fat and high-carbohydrate meals in women with different obesity phenotypes. J Clin Endocrinol Metab 2002;87:3984-3988. 
22. Sorensen LB, Moller P, Flint A, Martens M, Raben A. Effect of sensory perception of foods on appetite and food intake: a review of studies on humans. Int J Obes Relat Metab Disord 2003;27:1152-1166.

23. Westerterp-Plantenga MS. Fat intake and energy-balance effects. Physiol Behav 2004;83:579-585.

24. Westerterp KR, Verboeket-van de Venne WP, Westerterp-Plantenga MS, Velthuis-te Wierik EJ, de Graaf C, Weststrate JA. Dietary fat and body fat: an intervention study. Int J Obes Relat Metab Disord 1996;20:1022-1026.

25. Westerterp KR. Perception, passive overfeeding and energy metabolism. Physiol Behav 2006;89:62-65.

26. Stichting Nederlands Voedingsstoffenbestand. Dutch food composition table 2006. Utrecht, Netherlands: Noontetijl, 2006.

27. US Department of Agriculture, Agricultural Research Service. USDA National Nutrient Database for Standard Reference, Release 26. 2013. Available from: http://www.ars.usda.gov/ba/bhnrc.ndl.

28. Harris JA, Benedict FG. A Biometric Study of Human Basal Metabolism. Proc Natl Acad Sci U S A 1918;4:370-373.

29. Baecke JA, Burema J, Frijters JE. A short questionnaire for the measurement of habitual physical activity in epidemiological studies. Am J Clin Nutr 1982;36:936-942.

30. Johansson G, Westerterp KR. Assessment of the physical activity level with two questions: validation with doubly labeled water. Int J Obes (Lond) 2008;32:1031-1033.

31. Soenen S, Hochstenbach-Waelen A, Westerterp-Plantenga MS. Efficacy of alpha-Lactalbumin and Milk Protein on Weight Loss and Body Composition During Energy Restriction. Obesity 2011;19:370-39.

32. Murgatroyd PR, Coward WA. An improved method for estimating changes in whole-body fat and protein mass in man. Br J Nutr 1989;62:311-314.

33. Morrison CD, Reed SD, Henagan TM. Homeostatic regulation of protein intake: in search of a mechanism. Am J Physiol Regul Integr Comp Physiol 2012;302:R917-928.

34. Davidenko O, Darcel N, Fromentin G, Tome D. Control of protein and energy intake - brain mechanisms. Eur J Clin Nutr 2013;67:455-461.

35. Garlick PJ, McNurlan MA, Patlak CS. Adaptation of protein metabolism in relation to limits to high dietary protein intake. Eur J Clin Nutr 1999;53 Suppl 1:S34-43.

36. Gosby AK, Conigrave AD, Raubenheimer D, Simpson SJ. Protein leverage and energy intake. Obes Rev 2014;15:183-191.

37. Hao S, Sharp JW, Ross-Inta CM, McDaniel BJ, Anthony TG, Wek RC, Cavener DR, McGrath BC, Rudell JB, Koehnle TJ, et al. Uncharged tRNA and sensing of amino acid deficiency in mammalian piriform cortex. Science 2005;307:1776-1778.

38. Gietzen DW, Hao S, Anthony TG. Mechanisms of food intake repression in indispensable amino acid deficiency. Annu Rev Nutr 2007;27:63-78.

39. Maurin AC, Jousse C, Averous J, Parry L, Bruhat A, Cherasse $Y$, Zeng H, Zhang Y, Harding HP, Ron D, et al. The GCN2 kinase biases feeding behavior to maintain amino acid homeostasis in omnivores. Cell Metab 2005;1:273-277.

40. Ross CM, Sharp JW, Gietzen DW. elF2 alpha related signaling of amino acid deficiency in brain areas. Faseb Journal 2004;18:A145.

41. Millward DJ. Identifying recommended dietary allowances for protein and amino acids: a critique of the 2007 WHO/FAO/UNU report. Br J Nutr 2012;108 Suppl 2:S3-21.

42. FAO. Dietary protein quality evaluation in human nutrition. Report of an Food and Agriculture Organization Expert Consultation. FAO Food and Nutrition paper 92. Rome, Italy; 2013.

43. Tome D. Criteria and markers for protein quality assessment - a review. Br J Nutr 2012;108 Suppl 2:S222-229.

44. Tome D, Bos C. Dietary protein and nitrogen utilization. J Nutr 2000;130:1868S-1873S.

45. WHO/FAO/UNU. Protein and Amino Acid Requirements in Human Nutrition. Report of a Joint WHO/FAO/UNU Expert Consultation. WHO Technical Report Series No. 935. Geneva, Switzerland; 2007.

46. Westerterp-Plantenga MS. Modulatory factors in the effect of energy density on energy intake. $\mathrm{Br}$ J Nutr 2004;92 Suppl 1:S35-9. 
47. Stock MJ. Gluttony and thermogenesis revisited. Int J Obes Relat Metab Disord 1999;23: 1105-1117.

48. Miller DS, Mumford P. Gluttony. 1. An experimental study of overeating low- or high-protein diets. Am J Clin Nutr 1967;20:1212-1222.

49. Fuller MF, Garlick PJ. Human amino acid requirements: can the controversy be resolved? Annu Rev Nutr 1994;14:217-241.

50. Munro HN. General aspects of the regulation of protein metabolism by hormones. Academic Press: New York; 1964.

51. Stubbs RJ, Mazlan N, Whybrow S. Carbohydrates, appetite and feeding behavior in humans. J Nutr 2001;131:2775S-2781S.

52. Leidy HJ, Armstrong CL, Tang M, Mattes RD, Campbell WW. The influence of higher protein intake and greater eating frequency on appetite control in overweight and obese men. Obesity (Silver Spring) 2010;18:1725-1732.

53. Veldhorst MA, Nieuwenhuizen AG, Hochstenbach-Waelen A, Westerterp KR, Engelen MP, Brummer RJ, Deutz NE, Westerterp-Plantenga MS. Comparison of the effects of a high- and normal-casein breakfast on satiety, 'satiety' hormones, plasma amino acids and subsequent energy intake. Br J Nutr 2009;101:295-303.

54. Veldhorst MA, Nieuwenhuizen AG, Hochstenbach-Waelen A, Westerterp KR, Engelen MP, Brummer RJ, Deutz NE, Westerterp-Plantenga MS. Effects of high and normal soyprotein breakfasts on satiety and subsequent energy intake, including amino acid and 'satiety' hormone responses. Eur J Nutr 2009;48:92-100.

55. Veldhorst M, Smeets A, Soenen S, Hochstenbach-Waelen A, Hursel R, Diepvens K, Lejeune M, Luscombe-Marsh N, Westerterp-Plantenga M. Protein-induced satiety: effects and mechanisms of different proteins. Physiol Behav 2008;94:300-307.

56. Westerterp-Plantenga MS, Luscombe-Marsh N, Lejeune MPGM, Diepvens K, Nieuwenhuizen A, Engelen MPKJ, Deutz NEP, Azzout-Marniche D, Tome D, Westerterp KR. Dietary protein, metabolism, and body-weight regulation: dose-response effects. International Journal of Obesity 2006;30:S16-S23.

57. Westerterp-Plantenga MS, Lejeune MPGM, Smeets AJPG, Luscombe-Marsh ND. Sex differences in energy homeostatis following a diet relatively high in protein exchanged with carbohydrate, assessed in a respiration chamber in humans. Physiology \& Behavior 2009;97:414-419. 


\section{CHAPTER 5}

No protein intake compensation for insufficient indispensable amino acid intake with a low-protein diet for 12 days 


\section{ABSTRACT}

\section{Background}

Protein quality evaluation aims to determine the capacity of food sources and diets to meet protein and indispensable amino acid (IAA) requirements. This study determined whether nitrogen balance was affected and whether dietary IAA were adequately obtained from the ad libitum consumption of diets at three levels of protein from different primary sources for 12 days.

\section{Methods}

Two 12-day randomized crossover design trials were conducted in healthy subjects [ $n=70 / 67$ (M/F); age: 19-70 y; BMI: $18.2-38.7 \mathrm{~kg} / \mathrm{m}^{2}$ ]. The relative dietary protein content was lower than [5\% of energy (En\%)], similar to (15En\%), and higher than (30En\%) customary diets. These diets had a limited variety of protein sources, containing wheat protein as a single protein source (5En\%-protein diet) or 5En\% from wheat protein with 10En\% (15En\%-protein diets) or $25 \mathrm{En} \%$ (30En\%-protein diets) added from whey with $\alpha$-lactalbumin, soy or beef protein.

\section{Results}

There was a dose-dependent increase in nitrogen excretion with increasing dietary protein content, irrespective of the protein sources $(P=0.001)$. Nitrogen balance was maintained on the $5 \mathrm{En} \%$-protein diet, and was positive on the $15 \mathrm{En} \%$ - and $30 \mathrm{En} \%$-protein diets $(P<0.001)$ over 12 days. Protein intake from the 5En\%-protein diet did not reach the amount necessary to meet the calculated minimal IAA requirements, but IAA were sufficiently obtained from the $15 \mathrm{En} \%$ - and $30 \mathrm{En} \%$-protein diets. In the $15 \mathrm{En} \%$ - and $30 \mathrm{En} \%$-protein conditions, a higher protein intake from the soy-containing diets than from the whey with $\alpha$-lactalbumin or beef containing diets was needed to meet the minimal IAA requirements.

\section{Conclusion}

Protein intake did not compensate for an insufficient indispensable amino acid intake with a low-protein diet for 12 days. These trials were registered at clinicaltrials.gov as NCT01320189 and NCT01646749. 


\section{BACKGROUND}

Meeting metabolic needs for amino acids is crucial to ensure health (1). Amino acids provide nitrogen and carbon skeletons for tissue protein synthesis and for the production of nitrogenous compounds involved in a range of bodily functions (2). Many types of amino acids are needed physiologically but some cannot be synthesized in the body and must therefore be obtained through the diet; these amino acids are known as the dietary indispensable amino acids (IAA). Protein quality evaluation aims to determine the capacity of food sources and diets to meet protein and IAA requirements. Currently, nitrogen balance studies are primarily applied to define protein requirements as the degree to which protein intake compensates for obligatory losses of nitrogen from several pathways including amino acid breakdown $(1,3)$. However, nitrogen balance alone may be insufficient and other factors should be considered when determining protein requirement. For example, protein sources may influence the efficiency of protein utilization, and diets containing protein of lower quality are associated with increased losses of nitrogen $(2,4,5)$. Furthermore, the observation of a non-linear relationship between protein intake and nitrogen balance indicates the existence of metabolic adjustments to changes in protein intake $(2,6)$. The overall requirements of amino acids should consider adaptive components, such as net protein deposition and oxidative losses (3).

Due to a large inter-individual variability, even during energy balance and after metabolic adaptation, nitrogen balance studies are not sufficiently accurate to determine whether dietary protein intake meets IAA requirements $(1,3,7)$. In the context of protein-diets, the digestible IAA score (DIAAS) enables the determination whether dietary protein intake is sufficient for the metabolic needs for the individual IAA. The DIAAS permits the definition of protein quality by determination of the extent to which dietary IAA are provided in proportion to the requirements (1).

Recently, it has been proposed that humans either consume relatively more energy from a low-protein diet (8), or relatively less from a high-protein diet $(9,10)$. In these studies, complete protein leveraging was absent (8-10). It is unclear whether protein intake compensates for the protein-proportions to maintain nitrogen balance or to meet a sufficient amount of IAA. Compensatory intake of protein for obligatory loss of nitrogen is essential for normal growth and development in organisms $(1,3)$. The proposed mechanism to prevent negative nitrogen balance may be related to an observed signaling pathway that detects amino acid depletion (11-19). This study determined whether nitrogen balance was affected and whether dietary IAA were adequately obtained from the ad libitum consumption of diets at three levels of protein from different primary sources for 12 days. Data from two dietary intervention trials conducted over 12 consecutive days were combined and analyzed $(9,10)$. The relative dietary protein content was 
lower than [5\% of energy (En\%)], similar to (15En\%), and higher than (30En\%) customary diets. These diets had a limited variety of protein sources, containing wheat protein as single protein source (5En\%-protein diet) or $5 \mathrm{En} \%$ from wheat protein with 10En\% (15En\%-protein diets) or 25En\% (30En\%-protein diets) added from whey with $\alpha$-lactalbumin, soy or beef protein.

\section{METHODS}

Results from a trial on whey protein with $\alpha$-lactalbumin $(n=39)$ and soy protein $(n=40)$ at Maastricht University (9), and a two-center trial on beef protein $(n=58)$ at Maastricht University and at Purdue University (10) were combined for analysis. These studies were conducted according to the guidelines laid down in the Declaration of Helsinki and all procedures involving human subjects were approved by the Medical Ethical Committees of Maastricht University and Purdue University. Written informed consent was obtained from all subjects. The study on whey with $\alpha$-lactalbumin and soy protein was registered as NCT01320189 and that on beef protein as NCT01646749 at clinicaltrials.gov. Data on energy and protein intake of the separate studies has been previously published $(9,10)$. The present study encompasses the analyses on the nitrogen balances and on the DIAAS.

\section{Study subjects}

One hundred and eighty-six subjects were recruited, of whom 28 dropped out due to lack of time. Four subjects were excluded from the data analysis because of noncompliance, as shown by urinary nitrogen excretion. Overall, 137 subjects (70 men and 67 women) were included in the final data analysis. BMI ranged from $18.2-38.7 \mathrm{~kg} / \mathrm{m}^{2}$ and age from 19 to $70 \mathrm{y}(9,10)$. Subjects underwent screening that included anthropometric measurements and the completion of questionnaires eliciting information about health, smoking behavior, use of medications, alcohol consumption, physical activity, eating behavior and liking of the study meals. Subjects were non-smoking, not using more than moderate amounts of alcohol ( $>10$ drinks/wk), were weight stable (body weight change $<3 \mathrm{~kg}$ during the prior $6 \mathrm{mo}$ and had no planned weight change during the study period), were not using medication or supplements except for oral contraceptives in women, and rated the taste of the meals as acceptable [Visual analog scale (VAS) score for liking: $\geq 50 \mathrm{~mm}$ ] $(9,10)$. Individual daily energy requirements were calculated as the basal metabolic rate calculated with the formula of Harris and Benedict (20), times the physical activity level based on the Baecke Activity Questionnaire or on the two validated questions physical activity at work and at leisure time $(21,22)$. 


\section{Study design}

In the two single-blind, randomized crossover design trials, the relative protein content included $5 \mathrm{En} \%$ from wheat protein (5En\%-protein diet), and $5 \mathrm{En} \%$ from wheat protein with 10En\% (15En\%-protein diets) or 25En\% (30En\%-protein diets) from whey with $\alpha$-lactalbumin (Hiprotal Whey Protein Alpha; DOMO, FrieslandCampina), soy protein (SUPRO Soy Protein Isolate; Solae LLC) or beef protein. Subjects were randomly assigned to diets containing whey protein with $\alpha$-lactalbumin or the soy protein in trial one and all consumed beef protein in the second trial. The order of the three treatment arms for protein energy content was random for all subjects. Each dietary intervention lasted for a period of 12 consecutive days, in which subjects visited one of the universities for ad libitum consumption of breakfasts, lunches and dinners $(9,10)$. Prior work indicated that this period of intervention is long enough to reliably measure possible effects on energy and macronutrient intake (23). The wash-out period between the test sessions was $\sim 6$ wk to minimize carry-over effects and to take menstrual cycle phase effects into account in women on energy intake $(24,25)$.

\section{Diet composition}

Each protein-diet consisted of 5En\% from wheat flour protein. The 5En\%-protein condition contained wheat flour as a single protein source. In the $15 \%$-protein conditions, the protein content was comprised of $33 \%$ (5En\%) of wheat flour protein and of $67 \%(10 \mathrm{En} \%)$ of either whey plus $\alpha$-lactalbumin, soy or beef protein. Dairy protein was comprised of $70 \%$ of whey protein and of $30 \%$ of $\alpha$-lactalbumin. Protein content of the 30En\%-protein conditions comprised of $17 \%$ (5En\%) of wheat flour protein and of $83 \%$ (25En\%) of either beef, whey plus $\alpha$-lactalbumin or soy protein. Again, dairy protein content was comprised of $70 \%$ of whey protein and of $30 \%$ of $\alpha$-lactalbumin. The fat content between the meals and between the conditions was maintained at a constant proportion (35 En\%) to prevent possible effects of energy density and palatability on energy intake (26-28). The resulting diet compositions were 5/60/35 En\% from protein:carbohydrate:fat (low-protein), 15/50/35 En\% (medium-protein), and 30/35/35 En\% (high-protein). Moreover, the fiber content was comparable between the conditions.

\section{Biomarker of protein intake and nitrogen balance}

Nitrogen excretion, measured from 24-h urine collections at baseline (day 0) and at days 5 and 11, was used as a crude estimate of protein intake. Urine was collected in $2-1$ urine bottles containing $10 \mathrm{ml}$ of diluted hydrochloric acid $(4 \mathrm{mmol} / \mathrm{l})$ to prevent nitrogen loss through evaporation. Collection started after the first voiding in the morning on the collection days at 8:00h, and lasted through the first voiding on the next day at $8: 00 \mathrm{~h}$. The total volume of the $24-\mathrm{h}$ urine was recorded. Urine 
was gently mixed, and samples were taken and frozen at $-20^{\circ} \mathrm{C}$ until analysis. Nitrogen concentrations were measured with an elemental analyser (CHN-O-Rapid, Heraeus, Hanau, Germany, in the Netherlands, and Integra COBAS 400 plus, Roche Diagnostics GmbH, Rotkreuz, Switzerland, in the USA). Total nitrogen output was calculated as $24-\mathrm{h}$ urinary nitrogen plus $10 \%$ to account for normal losses via feces and other losses $(9,10)$. Nitrogen balance was calculated as the difference between nitrogen excretion and nitrogen intake.

\section{Protein intake}

Each meal was weighed to the nearest gram before it was provided to the subjects. Leftovers were reweighed to permit calculation of protein intake for each subject. Weights of provided snack items were also recorded, and the portions returned uneaten were weighed to determine the protein intake from the snacks per subject. Mean protein intake was calculated as the sum of protein intake from meals and from snacks $(9,10)$.

\section{DIAAS}

The IAA compositions of wheat protein and that of beef protein in the provided diets were obtained from the United States Department of Agricultural data base (29) and from a FAO publication (30) (Additional file 1). Amino acid analyses of specific food products provided the dietary IAA compositions of whey, $\alpha$-lactalbumin and soy protein (Supplemental Table S5.1) (31). The IAA content of the protein-diets was calculated as the sum of IAA of the separate proteins in the diets. Subsequently, the IAA content of the protein-diets was corrected for digestibility (Supplemental Table S5.2) (1). Since fecal protein represents largely bacterial protein, determination of undigested protein at the end of the ileum is a more reliable measure for the digestibility of dietary protein (32-34). Furthermore, the predicted ileal amino acid content needs to be corrected for ileal endogenous amino acids that are voided in the digestive tract. When the coefficients of amino acid digestibility are corrected for the endogenous amino acids, the resultant digestibility coefficients are considered as 'true' coefficients (1,32,33). Differences have been observed in the ileal digestibility of different proteins, as well as between different amino acids within each type of protein $(1,32,35)$. Therefore, in this study, the digestible IAA content was calculated for each individual IAA within each of the protein sources (wheat, whey with $\alpha$-lactalbumin, soy, and beef) as the dietary IAA content ( $\mathrm{mg} / \mathrm{g}$ protein) multiplied by the corresponding IAA true ileal digestibility coefficient. True ileal digestibility coefficients were obtained from a compound table representing observations in humans, pigs and rats from single studies or as means across studies (33). In general, digestibility coefficients for humans are used. When human data were not available, predictions for humans based on data obtained from growing pigs or rats were used, and then followed by 
digestibility coefficients for growing pigs or rats. For wheat flour protein, a predicted value obtained from pig true ileal amino acid digestibility was used, based on the equations of Deglaire and Moughan and from the endogenous amino acid losses determined using the protein-free diet method (32-34). A determined value in humans was available for the whey with $\alpha$-lactalbumin protein concentrate, whereby endogenous amino acid losses were determined using the protein-free diet method $(32-34,36)$. Also for soy protein isolate, amino acid digestibility coefficients corrected for endogenous amino acid losses were determined using the protein-free diet method. These were available from a human study by Moughan et al. $(32-34,36)$. Since specific studies on beef protein are scarce, the amino acid digestibility coefficients of meat protein hydrolysate determined in rats with endogenous amino acid losses determined using the enzyme hydrolyzed casein/ultrafiltration method, were used as representatives (33).

The minimal IAA requirements are the minimal intakes of IAA to avoid deficiencies $(37,38)$. These represent the profile of IAA intake to fulfill the obligatory role of maintenance. The DIAAS for the minimal IAA intakes were calculated for each IAA per protein-diet with the following formula (Supplemental Table S5.3):

DIAAS $(\%)=100 \times[(\mathrm{mg}$ of the digestible dietary IAA in $1 \mathrm{~g}$ of the dietary protein $) /$

( $\mathrm{mg}$ of the same dietary IAA in $1 \mathrm{~g}$ of the reference protein)] (1).

The DIAAS of a protein reflects the availability of the most limiting IAA relative to the minimal requirement. The lowest DIAAS indicates that the corresponding IAA is the most limiting IAA of the protein, and this score is used as the DIAAS for that protein. The minimal IAA scores for a reference protein were calculated with a minimal protein requirement value of $0.66 \mathrm{~g} / \mathrm{kg}$ body weight (BW)/d (1) (Supplemental Table S5.3). In our study, the minimal DIAAS for each IAA within the different protein-diets was calculated (Table 5.1). Thus, the lowest score represents the DIAAS for the corresponding protein-diet.

In order to assess whether subjects met their minimal IAA requirements by consuming the different protein-diets, the protein intake to meet these requirements was calculated per diet (Table 5.2).

Protein intake to meet dietary IAA requirements $(\mathrm{g} / \mathrm{kg} \mathrm{BW} / \mathrm{d})=$ [assumed dietary

IAA requirement (minimal: $0.66 \mathrm{~g} / \mathrm{kg} \mathrm{BW} / \mathrm{d}$ ) / DIAAS]. 
Table 5.1 Dietary IAA reference ratios for minimal IAA and DIAAS per protein diet

\begin{tabular}{lcccccccccc}
\hline & His & Ile & Leu & Lys & SAA & AAA & Thr & Val & Trp & DIAAS \\
\hline & & & & & & & & & & $\%$ (IAA) \\
$\begin{array}{l}\text { 5En\% wheat } \\
\text { 10En\% (+ 5En\% wheat) }\end{array}$ & 1.26 & 1.06 & 1.05 & 0.53 & 1.68 & 1.36 & 1.00 & 0.94 & 1.62 & 53 (Lys) \\
$\quad$ Whey + $\alpha$-lac & 1.19 & 1.63 & 1.45 & 1.47 & 2.00 & 1.50 & 1.90 & 1.13 & 3.06 & 113 (Val) \\
$\quad$ Soy & 1.29 & 1.14 & 1.00 & 0.84 & 1.09 & 1.01 & 1.10 & 0.89 & 1.54 & 84 (Lys) \\
$\quad$ Beef & 1.78 & 1.38 & 1.23 & 1.44 & 1.65 & 1.79 & 1.55 & 1.12 & 1.33 & 112 (Val) \\
25En (+ 5En\% wheat) & & & & & & & & & & \\
$\quad$ Whey + $\alpha$-lac & 1.17 & 1.77 & 1.55 & 1.69 & 2.08 & 1.53 & 2.12 & 1.18 & 3.41 & 117 (His) \\
$\quad$ Soy & 1.31 & 1.18 & 1.00 & 0.93 & 0.96 & 1.02 & 1.14 & 0.89 & 1.53 & 89 (Val) \\
Beef & 1.93 & 1.47 & 1.30 & 1.68 & 1.66 & 1.92 & 1.71 & 1.18 & 1.28 & 118 (Val) \\
\hline
\end{tabular}

$\alpha$-lac, $\alpha$-lactalbumin; AAA, aromatic amino acids (phenylalanine + tyrosine); DIAAS, digestible indispensable amino acid score; En\%, percentage of energy; IAA, indispensable amino acid; His, histidine; lle, isoleucine; Leu, leucine; Lys, lysine; SAA, sulphur amino acids (cysteine + methionine); Thr, threonine; Trp, tryptophan; Val, valine.

Table 5.2 Calculated protein intake to meet minimal IAA requirements and measured intake over 12 days

\begin{tabular}{|c|c|c|c|c|}
\hline & Calculated & Measured & Calculated & Measured \\
\hline & \multicolumn{2}{|c|}{$\mathrm{g} / \mathrm{kg} \mathrm{BW/d}$} & \multicolumn{2}{|c|}{$g / d$} \\
\hline 5 En\% wheat & 1.24 & 0.39 & 87.6 & 27.5 \\
\hline \multicolumn{5}{|l|}{$15 \mathrm{En} \%$} \\
\hline \multicolumn{5}{|c|}{5 En\% wheat + 10En\%: } \\
\hline Whey $+\alpha$-lac & 0.58 & 1.01 & 40.0 & 67.5 \\
\hline Soy & 0.78 & 0.98 & 57.8 & 70.7 \\
\hline Beef & 0.59 & 1.18 & 41.0 & 81.2 \\
\hline \multicolumn{5}{|l|}{ 30En\% } \\
\hline \multicolumn{5}{|c|}{5 En\% wheat + 25En\%: } \\
\hline Whey $+\alpha$-lac & 0.56 & 1.61 & 38.3 & 108.4 \\
\hline Soy & 0.74 & 1.56 & 54.5 & 113.4 \\
\hline Beef & 0.56 & 1.96 & 38.9 & 134.5 \\
\hline
\end{tabular}

$\alpha$-lac, $\alpha$-lactalbumin; BW, body weight; En\%, percentage of energy; IAA, indispensible amino acid.

\section{Statistical analysis}

SPSS version 20 for Macintosh OS X (SPSS Inc.) was used to perform statistical analyses. Differences in subject characteristics between protein groups were assessed using Factorial ANOVA. Factorial ANOVAs with repeated measures were applied to test whether nitrogen excretion and nitrogen balance changed in response to the dietary interventions within protein groups. Differences were regarded as statistically significant if $P<0.05$. Data are presented as mean \pm SD.

Possible effects of protein source on nitrogen excretion and nitrogen balance were evaluated by calculating the differences in response elicited by the different protein diets within each protein group. Kruskal-Wallis tests were used to evaluate whether these differences were affected by source of protein. Mann-Whitney tests 
were used to follow-up noted differences. The Monte Carlo method was applied to estimate the significance of the Mann-Whitney tests. Effect sizes for the MannWhitney tests were calculated by dividing the obtained $z$-scores by the corresponding number of subjects. A Bonferroni correction was applied so all effects are reported at a $0.05 / 3=0.017$ level of significance. Data are presented as median \pm range. Differences were regarded as statistically significant if $P<0.05$.

\section{RESULTS}

\section{Subject characteristics}

Subject characteristics are summarized per protein group in Table 5.3. Subject characteristics did not differ between the protein groups.

Table 5.3 Subject characteristics of the whey with $\alpha$-lactalbumin, soy and beef protein groups

\begin{tabular}{lccc}
\hline \hline & Whey protein & Soy protein & Beef protein \\
\hline Participants, M/F $(n)$ & $16 / 23$ & $24 / 26$ & $30 / 28$ \\
Age $(\mathrm{y})$ & $35 \pm 17$ & $34 \pm 19$ & $33 \pm 16$ \\
Age range $(\mathrm{y})$ & $18-70$ & $18-69$ & $19-70$ \\
Height $(\mathrm{cm})$ & $172 \pm 11$ & $174 \pm 10$ & $169 \pm 10$ \\
BW $(\mathrm{kg})$ & $68.6 \pm 13.8$ & $73.6 \pm 12.3$ & $69.8 \pm 11.8$ \\
BMI $\left(\mathrm{kg} / \mathrm{m}^{2}\right)$ & $23.1 \pm 3.5$ & $24.3 \pm 3.2$ & $24.4 \pm 4.0$ \\
BMI range $\left(\mathrm{kg} / \mathrm{m}^{2}\right)$ & $18.2-33.9$ & $18.1-33.4$ & $18.7-38.7$ \\
BMR $(\mathrm{MJ} / \mathrm{d})$ & $6.5 \pm 1.2$ & $6.9 \pm 1.0$ & $6.7 \pm 1.0$ \\
PAL & $1.76 \pm 0.15$ & $1.75 \pm 0.14$ & $1.73 \pm 0.16$ \\
DER $(\mathrm{MJ} / \mathrm{d})$ & $11.4 \pm 2.0$ & $12.1 \pm 2.1$ & $11.5 \pm 2.1$ \\
TFEQ Dietary restraint score & $6 \pm 4$ & $5 \pm 3$ & $6 \pm 4$ \\
TFEQ Disinhibition score & $4 \pm 2$ & $4 \pm 3$ & $4 \pm 3$ \\
TFEQ Hunger score & $4 \pm 2$ & $4 \pm 3$ & $4 \pm 3$ \\
\hline
\end{tabular}

Values shown as means \pm SDs. There were no significant differences between the protein groups (factorial ANOVA). BMR, basal metabolic rate; BW, body weight; DER, daily energy requirement; PAL, physical activity level; TFEQ, Three-Factor Eating Questionnaire.

\section{Biomarker of protein intake and nitrogen balance}

There was a dose-dependent increase in nitrogen excretion with increasing dietary protein content, irrespective of the protein sources $(P=0.001$, Table 5.4). In each condition, no significant difference between the urine collection at days 5 and 11 were observed, which indicates stable protein intakes within the conditions over the $12-d$ test periods $(9,10)$. Nitrogen balance did not differ significantly from zero on the 5En\%-protein-diet, and was positive on the $15 \mathrm{En} \%$ - and $30 \mathrm{En} \%$-protein diets $(P=0.001$, Table 5.4). The differences in nitrogen excretion and balance between the protein-diets were not affected by the sources of protein or by age. 
Table 5.4 Nitrogen excretion and nitrogen balance per protein diet

\begin{tabular}{lccc}
\hline \hline & Whey protein $(n=39)$ & Soy protein $(n=40)$ & Beef protein $(n=58)$ \\
\hline N excretion day 11 (mg/kg BW/d) & & & \\
5En\% (5En\% wheat) & $71.2 \pm 30.6^{\mathrm{a}}$ & $70.8 \pm 22.8^{\mathrm{a}}$ & $67.9 \pm 21.6^{\mathrm{a}}$ \\
15En\% (5En\% wheat + 10En\%) & $124.8 \pm 59.0^{\mathrm{b}}$ & $112.2 \pm 47.9^{\mathrm{b}}$ & $138.0 \pm 56.8^{\mathrm{b}}$ \\
30En\% (5En\% wheat + 25En\%) & $203.0 \pm 104.6^{\mathrm{c}}$ & $191.0 \pm 79.9^{\mathrm{c}}$ & $217.4 \pm 109.7^{\mathrm{c}}$ \\
$\mathrm{N}$ balance day 11 (mg/kg BW/d) & & & \\
5En\% (5En\% wheat) & $4.2 \pm 39.1^{\mathrm{a}}$ & $-6.9 \pm 28.3^{\mathrm{a}}$ & $3.5 \pm 27.6^{\mathrm{a}}$ \\
15En\% (5En\% wheat + 10En\%) & $47.6 \pm 52.1^{\mathrm{b}}$ & $48.5 \pm 43.5^{\mathrm{b}}$ & $50.1 \pm 60.4^{\mathrm{b}}$ \\
30En\% (5En\% wheat + 25En\%) & $73.5 \pm 69.6^{\mathrm{c}}$ & $71.5 \pm 53.9^{\mathrm{c}}$ & $95.8 \pm 110.1^{\mathrm{c}}$ \\
\hline
\end{tabular}

Values shown as means \pm SDs. Values with different superscript letters indicate significant differences between diets that differed in relative protein content, $P<0.05$ (in the whey, in the soy, or in the beef protein diets, repeated-measures ANOVA with Bonferroni correction for pairwise post-hoc comparisons). There were no significant differences between the protein groups (Non-parametric tests). BW, body weight; En\%, percentage of energy; N, nitrogen $P$, protein.

\section{Protein intake and DIAAS}

The DIAAS for minimal IAA intake are displayed for the 5En\%-protein diet, and for the $15 \mathrm{En} \%$ and $30 \mathrm{En} \%$-protein diets containing whey with $\alpha$-lactalbumin, soy or beef protein separately (Supplemental Table S5.3). Measured protein intake from the $5 \mathrm{En} \%$-wheat-protein diet was lower than the intake necessary to meet the calculated minimal IAA requirements (Table 5.2). Measured protein intake from the 15En\%- and 30En\%-protein diets was sufficient to meet minimal IAA requirements, irrespective of protein source. Age did not have an effect on differences in protein intake between conditions.

In line with previous data on amino acid composition, wheat flour protein was deficient in lysine, and had a lower total IAA content than whey with $\alpha$-lactalbumin, soy and beef protein (Supplemental Table S5.1). A characteristic of whey and $\alpha-$ lactalbumin protein was the relatively high abundance of leucine and lysine. Soy protein was lower in the sulphur amino acids (SAA) cysteine and methionine. The $15 \mathrm{En} \%$ - and $30 \mathrm{En} \%$-soy protein diets had a relatively lower IAA content than diets with comparable protein levels from whey with $\alpha$-lactalbumin or beef sources (Supplemental Table S5.2).

For the 5En\%-protein diet, the lowest minimal DIAAS was obtained for lysine. Valine and histidine were the most limiting IAA of the 15En\%- and 30En\%-protein diets containing whey with $\alpha$-lactalbumin protein (Table 5.1). For the $15 \mathrm{En} \%$ - and $30 \mathrm{En} \%$-protein diets containing soy, the most limiting IAA were lysine and valine respectively. The minimal DIAAS for the diets containing $15 \mathrm{En} \%$ and $30 \mathrm{En} \%$ from beef protein were ascribed to valine. DIAAS for minimal IAA intake were higher on the $15 \mathrm{En} \%$ - and $30 \mathrm{En} \%$-protein diets compared with the $5 \mathrm{En} \%$-protein diet. All the added protein sources tested were relatively high quality protein sources, but the DIAAS for minimal IAA intake only exceeded $100 \%$ for the whey with $\alpha$-lactalbumin and beef containing diets. In the $15 \mathrm{En} \%$ - and $30 \mathrm{En} \%$-protein conditions, a higher 
protein intake from the soy-containing diets than from the whey with $\alpha$ lactalbumin or beef containing diets was needed to meet the minimal IAA requirements.

\section{DISCUSSION}

This study determined whether nitrogen balance was affected and whether dietary IAA were adequately obtained from the ad libitum consumption of diets at three levels of protein from different primary sources for 12 days. The successful implementation of the dietary protein intervention on each condition in both trials was confirmed by urinary nitrogen concentrations. There was a dose-dependent increase in nitrogen excretion with increasing dietary protein content, irrespective of the protein sources. Despite protein intake with the $5 \mathrm{En} \%$-protein diet being below the minimal protein requirement of $0.66 \mathrm{~g} / \mathrm{kg} \mathrm{BW} / \mathrm{d}(1)$, it was sufficient to maintain nitrogen balance over 12 days. Nitrogen balance was positive on the 15En\%- and 30En\%-protein diets, irrespective of dietary protein composition. However, protein intake from the $5 \mathrm{En} \%$-protein diet did not reach the amount necessary to meet the calculated minimal IAA requirements, but IAA were sufficiently obtained from the $15 \mathrm{En} \%$ - and $30 \mathrm{En} \%$-protein diets. In the $15 \mathrm{En} \%$ - and 30 En\%-protein conditions, a higher protein intake from the soy-containing diets than from the whey with $\alpha$-lactalbumin or beef containing diets was needed to meet the minimal IAA requirements.

Data of this study suggest that the lower concentration of protein provided with the $5 \mathrm{En} \%$-protein diet was not outside the range that is feasible to maintain nitrogen balance over 12 days. The Adaptive Demands model developed by Millward may provide an explanation for this observation by proposing that the metabolic demand for amino acids comprises a fixed component and a variable adaptive component (39). Short-term changes in protein intake are likely within the adaptive range (3). Adaptations in protein and amino acid metabolism to changes in protein intake largely occur via changes in whole body protein turnover and amino acid oxidation $(2,40)$. Changes in amino acid oxidation were reflected as decreased and increased nitrogen excretion in response to the low- and highprotein diets respectively. The activity of the enzymes that regulates: 1) transamination, 2) the disposal of the carbon skeletons in intermediary metabolism, and 3) the disposal of nitrogen through the urea cycle was increased in response to high protein intake $(41,42)$. Nevertheless, a positive nitrogen balance was observed in the present study following the high-protein diets despite increased enzyme activities. This is in line with earlier observations $(2,43-45)$, but does not automatically reflect an increase in protein anabolism (3). The capacity of the body to increase amino acid anabolism through an increase in lean body mass is limited (3). Only interventions using diets high in specific IAA, such as leucine, 
might be able to stimulate protein synthesis in specific target groups $(46,47)$. Therefore, a transient retention or loss of body nitrogen because of a labile pool of body nitrogen may contribute to adaptations in amino acid metabolism in response to changes in protein intake (48). Transient adaptive mechanisms may be distinguished from mechanisms that maintain homeostasis in the body in the longer-term.

The calculated DIAAS for the 5En\%-protein diet were well below $100 \%$, which confirms that wheat is a low-quality protein. Especially at this low protein density, the intake of lysine was inadequate for satisfying the minimal IAA requirements. Protein intake should exceed $0.66 \mathrm{~g} / \mathrm{kg} \mathrm{BW} / \mathrm{d}$ to reach the minimal IAA intake. Consequently, measured intake from wheat protein being $0.39 \mathrm{~g} / \mathrm{kg} \mathrm{BW} / \mathrm{d}$ with the 5 En\%-protein diet means that minimal IAA requirements were not met. Protein intake was not spontaneously adjusted to reach the calculated optimal intake level of IAA. To meet the calculated minimal DIAAS level, subjects should have consumed $\sim 63 \mathrm{MJ}$ a day, from this diet. Interestingly, in animals, the detection of reduced concentrations of IAA in the anterior piriform cortex in the brain may result in deacetylation of the cognate transfer RNA (15). Subsequent activation of general amino acid nonderepressing kinase 2 may phosphorylate eukaryotic initation factor $2 \alpha$, a factor involved in the control of the initiation of translation in protein synthesis. This may lead to behavioral responses including under-consumption of diets that lack a minimal amount of IAA $(13,16,18)$. The findings of this study do not show a behavioral response in humans $(9,10)$. The lower concentration of protein provided in the present trials was not outside the range that is feasible to adjust protein intake. Nevertheless, a study (49) has documented acute food-choice compensation after low-protein meals in humans. After a low-protein meal, an increase in wanting and task-related signaling in the hypothalamus has been related to increased protein intake in a subsequent meal (49). Griffioen-Roose et al. (0) showed in a 4-day study that subjects increased their protein intake in a compensatory way during ad libitum feeding after a low-protein diet (5En\% from protein). Since no shift towards a higher energy intake from the $5 \mathrm{En} \%$ protein diet compared with the $15 \mathrm{En} \%$ protein diet was observed $(9,10)$, the insufficient amount of IAA clearly does not trigger a possible compensatory protein intake over 12 days. Observations from studies in developing countries show health deterioration related to low protein intake, especially of IAA, at intakes $<0.66 \mathrm{~g} / \mathrm{kg} \mathrm{BW} / \mathrm{d}$ (1). Thus, although we conclude that protein intake did not compensate for an insufficient IAAintake with a low-protein diet for 12 days, we do not propose that low-protein diets are sustainable.

Increasing the relative dietary protein content from whey with $\alpha$-lactalbumin, soy or beef protein resulted in an improved protein quality of the diets. However, the higher DIAAS of the whey with $\alpha$-lactalbumin and beef diets did not affect total daily protein intake differently compared with the lower DIAAS of the soy diets. Minimal requirements for IAA were reached with the ad libitum intake of each 
$15 \mathrm{En} \%$ and 30En\%-protein diet. However, a higher protein intake from the soycontaining diets than from the whey with $\alpha$-lactalbumin or beef containing diets was needed to meet the minimal IAA requirements. This corresponds with the recommendations for vegetarians to consume more protein or to include a combination of different plant protein sources in the diet. Furthermore, a larger amount of protein from whey with $\alpha$-lactalbumin or beef was available to fulfill roles beyond the obligatory role of maintenance. Since the subjects in this study were healthy, one of these roles may be the stimulation of muscle protein synthesis. The relative high abundance of leucine in whey with $\alpha$-lactalbumin protein may be beneficial to stimulate muscle protein synthesis (46).

The DIAAS can be applied in practice to examine protein quality of food products or mixed diets. However, it should be emphasized that the calculations of the DIAAS rely on some assumptions. First, the use of digestibility coefficients based on animal data is unavoidable when human data is not available. Second, the calculated protein intake necessary to meet minimal IAA requirements is based on the assumptions of a daily minimal protein requirement. This value may vary depending on dietary protein composition and should be adjusted according to subject-specific protein requirements. Factors influencing protein and amino acid metabolism, subsequently affecting protein and IAA requirements, should be further elucidated. Longer-term intervention studies with measurements of blood concentrations of amino acids and other key factors in appetite regulation, whole body protein turnover and muscle protein synthesis would provide more insight in the changes in protein and amino acid metabolism in response to dietary protein intake. Furthermore, possible IAA sensing pathways involved in the regulation of energy and protein metabolism in humans remain to be investigated.

\section{CONCLUSION}

To summarize, nitrogen balance was maintained on the $5 \mathrm{En} \%$-protein diet, and was positive on the $15 \mathrm{En} \%$ - and 30En\%-protein diets over 12 days. Despite this, the protein intake from the $5 \mathrm{En} \%$-protein diet did not reach the amount necessary to meet the calculated minimal IAA requirements, but IAA were sufficiently obtained from the 15En\%- and 30En\%-protein diets. In the 15En\%- and 30En\%-protein conditions, a higher protein intake from the soy-containing diets than from the whey with $\alpha$-lactalbumin or beef containing diets was needed to meet the minimal IAA requirements. In conclusion, protein intake did not compensate for an insufficient indispensable amino acid intake with a low-protein diet for 12 days. 


\section{ACKNOWLEDGEMENTS}

We thank Prof. Dr. Robert R. Wolfe and Prof. Dr. Paul J. Moughan for providing us detailed information about the calculation of DIAAS and Prof. Dr. Paul Moughan for his comments on the manuscript. 


\section{SUPPLEMENTAL TABLES}

Table S5.1 IAA composition per type of protein

\begin{tabular}{lllrrrrrrr}
\hline \hline & \multicolumn{10}{c}{ mg/g protein } \\
\cline { 2 - 10 } & His & lle & Leu & Lys & SAA & AAA & Thr & Val & Trp \\
\hline Wheat flour & 20 & 34 & 66 & 27 & 39 & 55 & 26 & 41 & 11 \\
Whey & 16 & 59 & 94 & 84 & 43 & 51 & 63 & 51 & 16 \\
a-lac & 27 & 57 & 107 & 103 & 60 & 81 & 48 & 43 & 38 \\
Soy & 20 & 37 & 60 & 46 & 18 & 68 & 28 & 35 & 10 \\
Beef & 34 & 48 & 81 & 89 & 40 & 80 & 46 & 50 & 8 \\
\hline
\end{tabular}

$\alpha$-lac, $\alpha$-lactalbumin; AAA, aromatic amino acids (phenylalanine + tyrosine); His, histidine; IAA, indispensable amino acid; lle, isoleucine; Leu, leucine; Lys, lysine; SAA, suphur amino acids (cysteine + methionine); Thr, threonine; Trp, tryptophan; Val, valine.

Table S5.2 True ileal digestible IAA and total IAA content per protein diet

\begin{tabular}{|c|c|c|c|c|c|c|c|c|c|c|}
\hline & \multicolumn{10}{|c|}{$\mathrm{mg} / \mathrm{g}$ protein } \\
\hline & His & Ile & Leu & Lys & SAA & AAA & Thr & Val & Trp & Total \\
\hline 5 En\% wheat & 19 & 32 & 62 & 24 & 37 & 52 & 23 & 37 & 10 & 294 \\
\hline \multicolumn{11}{|c|}{5 En $\%$ wheat + 10En\%: } \\
\hline Whey $+\alpha$-lac & 18 & 49 & 85 & 66 & 44 & 57 & 44 & 44 & 18 & 425 \\
\hline Soy & 19 & 34 & 59 & 38 & 24 & 61 & 25 & 35 & 9 & 305 \\
\hline Beef & 27 & 41 & 73 & 65 & 36 & 68 & 36 & 44 & 8 & 397 \\
\hline \multicolumn{11}{|c|}{5 En\% wheat + 25 En\%: } \\
\hline Whey $+\alpha$-lac & 18 & 53 & 91 & 76 & 46 & 58 & 49 & 46 & 20 & 457 \\
\hline Soy & 20 & 35 & 59 & 42 & 21 & 64 & 26 & 35 & 9 & 311 \\
\hline Beef & 29 & 44 & 76 & 76 & 37 & 73 & 39 & 46 & 8 & 428 \\
\hline
\end{tabular}

$\alpha$-lac, $\alpha$-lactalbumin; AAA, aromatic amino acids (phenylalanine + tyrosine); En\%, percentage of energy; His, histidine; IAA, indispensable amino acid; Ile, isoleucine; Leu, leucine; Lys, lysine; SAA, sulphur amino acids (cysteine + methionine); Thr, threonine; Trp, tryptophan; Val, valine.

Table S5.3 IAA reference pattern for minimal requirements

\begin{tabular}{ccccccccc}
\hline \hline \multicolumn{10}{c}{$m g / g$ protein } \\
\hline His & He & Leu & Lys & SAA & AAA & Thr & Val & Trp \\
\hline 15 & 30 & 59 & 45 & 22 & 38 & 23 & 39 & 6 \\
\hline
\end{tabular}

AAA, aromatic amino acids (phenylalanine + tyrosine); His, histidine; IAA, indispensable amino acid; Ile, isoleucine; Leu, leucine; Lys, lysine; SAA, sulphur amino acids (cysteine + methionine); Thr, threonine; Trp, tryptophan; Val, valine. 


\section{REFERENCES}

1. FAO. Dietary protein quality evaluation in human nutrition: Report of an FAO Expert Consultation. FAO Food and Nutrition paper 92. Rome: FAO; 2013.

2. Tome D, Bos C. Dietary protein and nitrogen utilization. J Nutr 2000;130:1868S-1873S.

3. Millward DJ. Identifying recommended dietary allowances for protein and amino acids: a critique of the 2007 WHO/FAO/UNU report. Br J Nutr 2012;108 Suppl 2:S3-21.

4. Millward DJ. Amino acid scoring patterns for protein quality assessment. Br J Nutr 2012;108 Suppl 2:S31-43.

5. Tome D. Criteria and markers for protein quality assessment - a review. Br J Nutr 2012;108 Suppl 2:S222-229.

6. Elango R, Ball RO, Pencharz PB. Recent advances in determining protein and amino acid requirements in humans. Br J Nutr 2012;108 Suppl 2:S22-30.

7. Millward DJ. Macronutrient intakes as determinants of dietary protein and amino acid adequacy. J Nutr 2004;134:1588S-1596S.

8. Gosby AK, Conigrave AD, Lau NS, Iglesias MA, Hall RM, Jebb SA, Brand-Miller J, Caterson ID, Raubenheimer D, Simpson SJ. Testing protein leverage in lean humans: a randomised controlled experimental study. PLoS One 2011;6:e25929.

9. Martens EA, Lemmens SG, Westerterp-Plantenga MS. Protein leverage affects energy intake of high-protein diets in humans. Am J Clin Nutr 2013;97:86-93.

10. Martens EA, Tan SY, Dunlop MV, Mattes RD, Westerterp-Plantenga MS. Protein leverage effects of beef protein on energy intake in humans. Am J Clin Nutr 2014;99:1397-1406.

11. Aparecida de Franca S, Dos Santos MP, Garofalo MA, Navegantes LC, Kettelhut Ido C, Lopes CF, Kawashita NH. Low protein diet changes the energetic balance and sympathetic activity in brown adipose tissue of growing rats. Nutrition 2009;25:1186-1192.

12. Du FY, Higginbotham DA, White BD. Food intake, energy balance and serum leptin concentrations in rats fed low-protein diets. Journal of Nutrition 2000;130:514-521.

13. Gietzen DW, Hao S, Anthony TG. Mechanisms of food intake repression in indispensable amino acid deficiency. Annu Rev Nutr 2007;27:63-78.

14. Gietzen DW, Rogers QR. Nutritional homeostasis and indispensable amino acid sensing: a new solution to an old puzzle. Trends Neurosci 2006;29:91-99.

15. Hao S, Sharp JW, Ross-Inta CM, McDaniel BJ, Anthony TG, Wek RC, Cavener DR, McGrath BC, Rudell JB, Koehnle TJ, et al. Uncharged tRNA and sensing of amino acid deficiency in mammalian piriform cortex. Science 2005;307:1776-1778.

16. Maurin AC, Jousse C, Averous J, Parry L, Bruhat A, Cherasse Y, Zeng H, Zhang Y, Harding HP, Ron D, et al. The GCN2 kinase biases feeding behavior to maintain amino acid homeostasis in omnivores. Cell Metab 2005;1:273-277.

17. Meyer JH. Interactions of dietary fiber and protein on food intake and body composition of growing rats. Am J Physiol 1958;193:488-494.

18. Ross CM, Sharp JW, Gietzen DW. elF2 alpha related signaling of amino acid deficiency in brain areas. Faseb Journal 2004;18:A145.

19. White BD, Porter MH, Martin PJ. Protein selection, food intake, and body composition in response to the amount of dietary protein. Physiology \& Behavior 2000;69:383-389.

20. Harris JA, Benedict FG. A Biometric Study of Human Basal Metabolism. Proc Natl Acad Sci U S A 1918;4:370-373.

21. Baecke JA, Burema J, Frijters JE. A short questionnaire for the measurement of habitual physical activity in epidemiological studies. Am J Clin Nutr 1982;36:936-942.

22. Johansson G, Westerterp KR. Assessment of the physical activity level with two questions: validation with doubly labeled water. Int J Obes (Lond) 2008;32:1031-1033.

23. Edholm OG. Energy balance in man studies carried out by the Division of Human Physiology, National Institute for Medical Research. J Hum Nutr 1977;31:413-431.

24. Vicennati V, Ceroni L, Gagliardi L, Gambineri A, Pasquali R. Comment: response of the hypothalamic-pituitary-adrenocortical axis to high-protein/fat and high-carbohydrate meals in women with different obesity phenotypes. J Clin Endocrinol Metab 2002;87:3984-3988. 
25. Sorensen LB, Moller P, Flint A, Martens M, Raben A. Effect of sensory perception of foods on appetite and food intake: a review of studies on humans. Int J Obes Relat Metab Disord 2003;27:1152-1166.

26. Westerterp KR. Perception, passive overfeeding and energy metabolism. Physiol Behav 2006;89:62-65.

27. Westerterp-Plantenga MS. Fat intake and energy-balance effects. Physiol Behav 2004;83:579-585.

28. Westerterp KR, Verboeket-van de Venne WP, Westerterp-Plantenga MS, Velthuis-te Wierik EJ, de Graaf C, Weststrate JA. Dietary fat and body fat: an intervention study. Int J Obes Relat Metab Disord 1996;20:1022-1026.

29. FAO. Amino-acid content of foods and biological data on proteins. FAO Food and Nutrition series. Rome: FAO; 1970.

30. United States Department of Agriculture. Agricultural Research Service. SR25 Page Reports. Version current September 2013. Available from: http://www.ars.usda.gov/Services/ docs.htm?docid=22770 (cited June 2014).

31. Rutherfurd SM, Bains K, Moughan PJ. Available lysine and digestible amino acid contents of proteinaceous foods of India. Br J Nutr 2012;108 Suppl 2:S59-68.

32. Deglaire A, Moughan PJ. Animal models for determining amino acid digestibility in humans - a review. Br J Nutr 2012;108 Suppl 2:S273-281.

33. Moughan PJ, Gilani S, Rutherfurd SM, Tomé D. True ileal amino acid digestibility coefficients for application in the calculation of Digestible Indispensable Amino Acid Score (DIAAS) in human nutrition. Rome:FAO; 2012.

34. Rowan AM, Moughan PJ, Wilson MN, Maher K, Tasman-Jones C. Comparison of the ileal and faecal digestibility of dietary amino acids in adult humans and evaluation of the pig as a model animal for digestion studies in man. Br J Nutr 1994;71:29-42.

35. FAO/WHO. Protein Quality Evaluation: Report of the Joint FAO/WHO Expert Consultation. FAO Food and Nutrition paper 51. Rome: FAO; 1991.

36. Moughan PJ, Butts CA, Rowan AM, Deglaire A. Dietary peptides increase endogenous amino acid losses from the gut in adults. Am J Clin Nutr 2005;81:1359-1365.

37. Wolfe RR. The role of dietary protein in optimizing muscle mass, function and health outcomes in older individuals. Br J Nutr 2012;108 Suppl 2:S88-93.

38. Wolfe RR. Perspective: Optimal protein intake in the elderly. J Am Med Dir Assoc 2013;14:65-66.

39. Millward DJ. An adaptive metabolic demand model for protein and amino acid requirements. $\mathrm{Br} \mathrm{J}$ Nutr 2003;90:249-260.

40. Deutz NE, Wolfe RR. Is there a maximal anabolic response to protein intake with a meal? Clin Nutr 2013;32:309-313.

41. Harper AE, Miller RH, Block KP. Branched-chain amino acid metabolism. Annu Rev Nutr 1984;4:409-454.

42. Harper AE. Some recent developments in the study of amino acid metabolism. Proc Nutr Soc 1983;42:437-449.

43. Garlick PJ, McNurlan MA, Patlak CS. Adaptation of protein metabolism in relation to limits to high dietary protein intake. Eur J Clin Nutr 1999;53 Suppl 1:S34-43.

44. Price GM, Halliday D, Pacy PJ, Quevedo MR, Millward DJ. Nitrogen homeostasis in man: influence of protein intake on the amplitude of diurnal cycling of body nitrogen. Clin Sci (Lond) 1994;86: 91-102.

45. Pannemans DL, Halliday D, Westerterp KR, Kester AD. Effect of variable protein intake on wholebody protein turnover in young men and women. Am J Clin Nutr 1995;61:69-74.

46. van Loon LJ. Leucine as a pharmaconutrient in health and disease. Curr Opin Clin Nutr Metab Care 2012;15:71-77.

47. Millward DJ. Knowledge gained from studies of leucine consumption in animals and humans. J Nutr 2012;142:2212S-9S.

48. Munro HN. General aspects of the regulation of protein metabolism by hormones. In: Munro HN, Allison JB, ed. Mammalian Protein Metabolism. New York: Academic Press, 1964.

49. Born JM, Martens MJ, Lemmens SG, Goebel R, Westerterp-Plantenga MS. Protein v. carbohydrate intake differentially affects liking- and wanting-related brain signalling. Br J Nutr 2013;109: 376-381. 
50. Griffioen-Roose S, Mars M, Siebelink E, Finlayson G, Tome D, de Graaf C. Protein status elicits compensatory changes in food intake and food preferences. Am J Clin Nutr 2012;95:32-38.

51. WHO/FAO/UNU. Protein and Amino Acid Requirements in Human Nutrition. Report of a Joint WHO/FAO/UNU Expert Consultation. WHO Technical Report Series No 935. Geneva, FAO; 2007. 


\section{CHAPTER 6}

Postprandial changes in appetite relate to postprandial changes in amino acid, GLP-1, ghrelin, and insulin concentrations after casein-, soy-, and whey-protein breakfasts 


\begin{abstract}
Protein-induced satiety has been proposed as the main mechanism behind the beneficial effects of high-protein diets for body weight management. This study assessed the withinsubject relations between postprandial changes in hunger and fullness ratings, and the postprandial changes in amino acid, GLP-1, ghrelin, glucose, and insulin concentrations following the consumption of normal and high casein-, soy-, or whey-protein containing breakfasts. Healthy subjects ( $n=25$, age: $22 \pm 1 \mathrm{y}$, BMI: $23.9 \pm 0.3 \mathrm{~kg} / \mathrm{m}^{2}$ ) received standardized breakfasts with casein-, soy-, or whey-protein, with $10 / 55 / 35$ or $25 / 55 / 20 \%$ of energy (En\%) protein/carbohydrate/fat (randomized cross-over design). Hunger and fullness ratings, and plasma amino acid, GLP-1, ghrelin, glucose, and insulin concentrations were determined for $\mathbf{2 4 0} \mathrm{min}$. Postprandial increases in fullness ratings were related to increases in concentrations of most amino acids, irrespective of protein content and protein type. The amino acids arginine, asparagine, isoleucine, leucine, lysine, and phenylalanine showed a $R^{2}>50 \%$ in the breakfasts with $10 \mathrm{En} \%$ from casein-, soy-, or whey-protein, as well as with $25 \mathrm{En} \%$ from whey-protein. GLP-1, insulin and ghrelin concentrations were related to postprandial hunger and fullness responses, for ghrelin and insulin sometimes as trends. Glucose concentrations showed less strong relations with hunger and fullness. To conclude, postprandial kinetics of arginine, asparagine, isoleucine, leucine, lysine, and phenylalanine were related to casein-, soy, and whey-protein-induced fullness especially at $10 \mathrm{En} \%$ of protein, while the postprandial kinetics of GLP-1, ghrelin, and insulin were also related to changes in appetite at $25 \mathrm{En} \%$ of these proteins.
\end{abstract}




\section{INTRODUCTION}

In the light of prevention and treatment of the current epidemic of overweight and obesity, protein-diets have come into focus as having the potential to act on the different metabolic targets regulating body weight $(1,2)$. Protein is generally known as being the most satiating macronutrient on a calorie for calorie basis (3), with protein-induced satiety proposed as main mechanism behind the beneficial effects of high-protein diets for body weight management. Mellinkoff et al. showed in 1956 significant inverse correlations between changes in the serum amino acid concentration and fluctuations in appetite $\left(R^{2}=0.2-0.4\right)(4)$. Whether induced by feeding of protein or amino acids, or by infusing amino acid mixtures, appetite decreased when serum (4) or plasma amino acid concentrations (5-9) increased, and vice versa. More specifically, postprandial increases in plasma concentrations of single or groups of amino acids have been observed to coincide with the development of satiety $(5-8,10)$. Hall et al. showed increased fullness ratings and total plasma amino acid concentrations following a liquid whey preload compared with casein (6). The larger total plasma amino acid response following whey compared with casein was largely attributed to larger increases in concentrations of isoleucine (102\%), leucine (70\%), threonine (95\%), and valine (34\%) (6). Veldhorst et al. showed that at 10 energy percent (En\%) protein, whey decreased hunger ratings more than casein or soy, coinciding with larger isoleucine, leucine, lysine, threonine, and tryptophan responses (5). Moreover, it was shown that a $25 \mathrm{En} \%$ vs. a $10 \mathrm{En} \%$ casein-protein breakfast was more satiating at 3 and $4 \mathrm{~h}$ postprandial, coinciding with prolonged elevated concentrations of the sum of amino acids as well as of the branched-chain amino acids (8). However, betweensubject relations were not observed. With respect to soy protein, satiety ratings were more increased after a breakfast with $25 \mathrm{En} \%$ vs. $10 \mathrm{En} \%$ of protein (7). Postprandial satiety and hunger suppression were positively related to taurine concentrations. Furthermore, responses of almost all amino acids were larger after a $25 \mathrm{En} \%$ than after a $10 \mathrm{En} \%$ whey-protein breakfast (9). However, satiety ratings were more increased after a breakfast with $10 \mathrm{En} \%$ whey-protein than with $25 \mathrm{En} \%$ whey-protein (9). Acheson et al. observed increased plasma amino acid concentrations after casein-, soy-, and whey-protein meals, with total amino acid concentrations reaching higher peak values at $60 \mathrm{~min}$ and $120 \mathrm{~min}$ after the wheyprotein meal compared with the casein- or soy-protein meals, due to increases of the amino acids isoleucine, leucine, lysine, and valine (10). In this study, wheyprotein was found to be less satiating than casein- or soy-protein.

Apart from amino acids, the anorexigenic gut peptide glucagon-like peptide 1 (GLP-1), the orexigenic gut peptide ghrelin, glucose and insulin may also play a role in protein-induced satiety (11) GLP-1 is released from the endocrine L-cells of the gastrointestinal tract in response to food intake in proportion to the caloric intake and in relation to the macronutrient composition $(11,12)$. Increased concentrations 
of GLP-1 have been shown to reduce appetite (12). Ghrelin is secreted primarily by the gastric X-cells during fasting (11). Ghrelin appears to stimulate appetite $(13,14)$, and may play a role in meal initiation (11). Furthermore, changes in plasma glucose concentrations may be involved in food intake regulation $(11,15)$. Postprandial increases in glucose concentrations trigger insulin secretion by the $\beta$-cells of the pancreatic islets, which induces anorexigenic effects $(15,16)$. Veldhorst et al. have shown stronger glucose and insulin responses after a $10 \mathrm{En} \%$ vs. a $25 \mathrm{En} \%$ caseinprotein breakfast, but no further effects on GLP-1 and ghrelin concentrations were observed (8). With respect to soy-protein, a stronger peak response of glucose was shown after a 10 En\%-protein breakfast, but the insulin response was higher after a 25En\%-protein breakfast. Postprandial GLP-1 and ghrelin responses were not differently affected (7). At $25 \mathrm{En} \%$, whey-protein showed a stronger physiological reaction than casein- and soy-protein through stronger GLP-1 and insulin responses (9).

However, apart from the correlations between satiety and fullness, and taurine concentrations after a $25 \mathrm{En} \%$ soy-protein breakfast, no between-subject correlations between postprandial appetite ratings and postprandial amino acid, (an)orexigenic hormone, glucose, and insulin concentrations were observed (5,7-9). It seems obvious that the ingestion of larger meals evokes stronger meal-size related fullness, amino acid, (an)orexigenic hormone, glucose, and insulin responses. Likely, a higher fullness is rated only within subjects (23). Between subjects, differences in individual energy requirements play a role (17), and we advocate that fullness ratings are related to the magnitude of achieved energy intake relative to energy requirement. Therefore, fullness ratings may be the same between subjects of different sizes who ingest different amounts of food, and therefore, between-subject magnitudes of energy intake relate rather to different subject-sizes than to fancied different levels of hunger or fullness. However, the question remains whether the within-subject changes in hunger and fullness ratings in the course of a meal, relate to the within-subject changes in concentrations of amino acids, (an)orexigenic hormones, glucose, and insulin.

The present study assessed the within-subject relations between postprandial changes in hunger and fullness ratings, and the postprandial changes in amino acid, GLP-1, ghrelin, glucose, and insulin concentrations following the consumption of normal and high casein-, soy-, or whey-protein containing breakfasts. The aim was to find different associations that might relate to the observed differences in postprandial hunger and fullness between proteins as well as between different dosages of the same protein.

\section{MATERIALS AND METHODS}

Data on the comparisons of high (25En\%) vs. normal (10En\%) casein-, soy-, and whey-protein breakfasts, that were previously collected and published in peer- 
reviewed journals by Veldhorst et al. (5,7-9) were further analyzed. None of the outcomes of the present within-subjects analyses on the possible relations between postprandial changes in hunger- and fullness-ratings and changes in amino acid, GLP-1, ghrelin, glucose, and insulin concentrations were reported in these papers $(5,7-9)$. This section summarizes the protocols that were used by Veldhorst et al. (5,7-9).

\section{Subjects}

Twenty-five healthy Caucasian subjects (11 men and 14 women; age $22 \pm 1$ y (range $19-38 \mathrm{y}$ ); body weight $74.4 \pm 1.8 \mathrm{~kg}$ ) with a BMI of $23.9 \pm 0.3 \mathrm{~kg} / \mathrm{m}^{2}$ (range $21.8-27.1 \mathrm{~kg} / \mathrm{m}^{2}$ ) participated in those studies (7-9). Subjects were selected on the basis of being in good health, non-smokers, non-vegetarian, not cognitively dietary restraint (Three-Factor Eating Questionnaire Factor 1 score $\leq 9)$ (18), not using medication apart from oral contraceptives, and at most moderate alcohol users ( $\leq 10$ alcoholic consumptions/wk). All subjects gave written informed consent. The studies were approved by the Medical Ethical Committee of the Maastricht University, and were in accordance with the Helsinki Declaration of 1975 as revised in 1983. A full description of the subject recruitment has been reported in the papers by Veldhorst et al. (5,7-9).

\section{Study design}

Three single-blind, within-subject experimental studies were performed, according to the same design, in random order (5,7-9). For the women, the experiments were carried out in the same phase of the menstrual cycle. The protocol started at 08:00 $\mathrm{h}$ after an overnight fast from 22:00 h. A Venflon catheter was placed in a superficial dorsal vein of the hand. To obtain arterialized venous blood samples the hand was placed in a thermostatically controlled hot box at $60^{\circ} \mathrm{C}$ for $20 \mathrm{~min}$ before each sampling time. Breakfast was offered ( $t=0 \mathrm{~min}$ ) and consumed within $20 \mathrm{~min}$. Appetite ratings and amino acid concentrations were measured just before breakfast and at 20,40,60, 80, 100, 120, 180, and 240 min after breakfast. Blood samples for the determination of GLP-1 concentrations were obtained at 30, 60, 90 and $120 \mathrm{~min}$ after breakfast, and those for the determination of ghrelin, glucose and insulin at 40,60, 120 and 180 min after breakfast. Subjects were allowed to drink maximally two glasses of water spread over the morning. A full description of the study design has been reported in the papers by Veldhorst et al. $(5,7-9)$.

\section{Breakfast}

Breakfast was offered as a custard with either casein (Calcium Caseinate $\mathrm{S}$, DMVInternational, Veghel, The Netherlands), soy (Supro ${ }^{\circledR} 590$, The Solae Company, St. Louis, MO, United States of America), or whey (whey, Ultra Whey 90, Volactive 
Functional Food Products, Orwell, United Kingdom) as a single protein source with an En\% protein/carbohydrate/fat of 10:55:35 (normal protein) or 25:55:20 (high protein), as described before (5,7-9). Protein was exchanged with fat; carbohydrate content was kept constant because of its effect on protein metabolism (19). All custards had an energy density of $4 \mathrm{~kJ} / \mathrm{g}$. The amount of the breakfast subjects had to consume corresponded to $20 \%$ of their individual daily energy requirement (DER). For each subject the DER was calculated by multiplying the basal metabolic rate (BMR) by an activity index of 1.75 , as indicated by the Baecke questionnaire (20). This value corresponds with the average value reported for the general population in The Netherlands (21). The BMR was calculated according to the equation of Harris-Benedict (17).

The mean energy content of the breakfast was $2.5 \pm 0.07 \mathrm{MJ}$ and the provided breakfasts were finished within 20 min. The custards were produced by NIZO Food Research bv. (Ede, The Netherlands). Extensive product development and use of a taste panel lead to custards not different in color, taste, or viscosity. The amino acid composition of the custards is presented in Table 6.1 (5,7-9).

Pleasantness of taste of the custards was rated as sufficient (VAS score $\geq 50 \mathrm{~mm}$ ) (7-9). Taste perception ratings of pleasantness of taste, sweetness, sourness, saltiness, bitterness, savouriness, crispiness, and creaminess did not differ by protein type and content (5,7-9). A full description of the breakfast characteristics has been reported in the papers by Veldhorst et al. $(5,7-9)$.

Table 6.1 Amino acid content of the breakfasts given as a custard with either $10 \mathrm{En \%}$ or 25 En\% from casein, soy, or whey protein (g amino acid/100 g custard) (5,7-9)

\begin{tabular}{lcccccc}
\hline \hline & Casein & Casein & Soy & Soy & Whey & Whey \\
& $10 \mathrm{En} \%$ & $25 \mathrm{En} \%$ & $10 \mathrm{En} \%$ & $25 \mathrm{En} \%$ & 10 En\% & $25 \mathrm{En} \%$ \\
\hline Alanine & 0.064 & 0.150 & 0.073 & 0.182 & 0.106 & 0.266 \\
Arginine & 0.092 & 0.218 & 0.139 & 0.345 & 0.055 & 0.139 \\
Aspartic acid $^{1}$ & 0.150 & 0.355 & 0.200 & 0.497 & 0.230 & 0.579 \\
Cysteine $_{\text {Glutamic acid }}$ & 0.009 & 0.021 & 0.022 & 0.054 & 0.055 & 0.139 \\
Glycine & 0.477 & 1.127 & 0.328 & 0.816 & 0.381 & 0.957 \\
Histidine & 0.040 & 0.094 & 0.071 & 0.177 & 0.035 & 0.088 \\
Isoleucine & 0.064 & 0.152 & 0.048 & 0.119 & 0.039 & 0.097 \\
Leucine & 0.112 & 0.265 & 0.089 & 0.222 & 0.141 & 0.355 \\
Lysine & 0.204 & 0.483 & 0.145 & 0.360 & 0.226 & 0.567 \\
Methionine & 0.172 & 0.405 & 0.110 & 0.274 & 0.201 & 0.504 \\
Phenylalanine & 0.064 & 0.152 & 0.022 & 0.056 & 0.048 & 0.121 \\
Proline & 0.110 & 0.259 & 0.094 & 0.234 & 0.062 & 0.156 \\
Serine & 0.230 & 0.544 & 0.087 & 0.216 & 0.128 & 0.321 \\
Threonine & 0.120 & 0.283 & 0.089 & 0.220 & 0.099 & 0.249 \\
Tryptophan & 0.090 & 0.214 & 0.066 & 0.164 & 0.150 & 0.378 \\
Tyrosine & 0.027 & 0.064 & 0.023 & 0.057 & 0.039 & 0.099 \\
Valine & 0.120 & 0.283 & 0.069 & 0.171 & 0.061 & 0.154 \\
\hline
\end{tabular}

${ }^{1}$ Aspartic acid = asparagine. ${ }^{2}$ Glutamic acid = glutamine + glutamate. GMP, glycomacropeptide. 


\section{Appetite ratings}

VAS (100 mm) were used to assess appetite with separates scales for hunger and fullness. The scales were anchored with 'not at all' and 'extremely' (5,7-9).

\section{Blood parameters}

As reported in the papers by Veldhorst et al. $(5,7-9)$ blood was collected in lithium heparin tubes for the determination of amino acid concentrations. The plasma was deproteinized by mixing it with dry sulfosalicylic acid. Blood was distributed into EDTA tubes for the measurement of active ghrelin, glucose and insulin concentrations, with hydrochloric acid and phenylmethylsulfonyl fluoride added for the determination active ghrelin. For the determination of active GLP-1 concentrations, blood was collected in EDTA tubes with added dipeptidyl peptidase IV inhibitor. Blood samples were centrifuged at $4^{\circ} \mathrm{C}$ for $10 \mathrm{~min}$ at $3000 \mathrm{rpm}$. All samples were stored at $-80^{\circ} \mathrm{C}$ until further analysis. Plasma concentrations of amino acids were determined with the use of a fully automated HPLC (Pharmacia, Woerden, The Netherlands), after precolumn derivatization with o-phthaldialdehyde (22). Plasma active GLP-1 and active ghrelin concentrations were measured by ELISA (EGLP-35K; Linco Research Inc., St. Charles, Missouri, USA). Plasma glucose concentrations were determined using the hexokinase method (Glucose HK 125 kit, ABX diagnostics, Montpellier, France). Insulin concentrations were measured by RIA (Linco Research Inc., St. Charles, Missouri, USA) (5,7-9).

\section{Statistics}

The actual analyses tested the strength of the within-subject relations between postprandial changes in hunger and fullness ratings, and postprandial changes in plasma amino acid, GLP-1, ghrelin, glucose, and insulin concentrations. This was performed with the statistical approach described and applied by Lemmens et al. (23). We calculated, for each subject individually, as well as averaged over all subjects, regression slopes and $R^{2}$ values for the regression of hunger and fullness ratings on the plasma amino acid, GLP-1, ghrelin, glucose and insulin concentrations for the corresponding measuring moments following the consumption of breakfasts with either $10 \mathrm{En} \%$ or $25 \mathrm{En} \%$ from casein-, soy-, or whey-protein.

ANOVA repeated measures were used to test whether the regression slopes for each subject individually, as well as for the means of the regression slopes, for each condition, were different from zero. In case the within-subject and mean regression slopes were significantly different from zero, the regression was considered as statistically significant (23). Then, the lowest $R^{2}$ value among the subjects was taken to indicate the magnitude of explained variation. All tests were two-sided 
and differences were considered significant at $P<0.05$. Values are expressed as means $( \pm S D)$. Data were analyzed using SPSS version 18 for Macintosh OS X.

\section{RESULTS}

The present results of the within-subject tests show that increases in fullness ratings were positively related to increases in plasma concentrations of all amino acids, except for citrulline, following the consumption of breakfasts with either $10 \mathrm{En} \%$ or $25 \mathrm{En} \%$ from casein, soy, or whey protein (Table 6.2 ). For citrulline, the relation between fullness ratings and plasma concentrations was inverse. The means of the regression slopes for fullness as a function of single amino acids were significantly different from zero for almost all amino acids within each condition (Table 6.2, $P<0.05$ ). The amino acids arginine, asparagine, isoleucine, leucine, lysine, and phenylalanine showed a $R^{2}>50 \%$ in the breakfasts with $10 \%$ of energy from casein-, soy-, or whey-protein, as well as with $25 \mathrm{En \%}$ from whey-protein (Table 6.2). The means of the within-subject relations between postprandial changes in fullness and postprandial changes in the concentrations of these amino acids are shown in Figure 6.1.

Postprandial decreases in ratings of hunger and increases in ratings of fullness were either linearly or cubistically significantly related to changes in concentrations of GLP-1, ghrelin, glucose, and insulin following the consumption of the breakfast containing 10En\% casein (Table 6.3, $P<0.05$ ). These relations were also present for GLP-1 and ghrelin, but only partly for insulin, and not for glucose following the consumption of the $25 \mathrm{En} \%$-casein breakfast (Table $6.3, P<0.05$ ). For soy $10 \mathrm{En} \%$, changes in ratings for hunger or fullness were either linearly or cubistically significantly related to changes in concentrations of GLP-1 and insulin, whereas for soy $25 \mathrm{En} \%$, such relations were also present for ghrelin $(P<0.05)$, and as trends for glucose (Table 6.3). Similar relations were present for GLP-1, glucose, and insulin $(P<0.05)$, and as trends for ghrelin following the consumption of the $10 \mathrm{En} \%$-whey breakfast. For whey $25 \mathrm{En} \%$, all relations were present except for glucose (Table 6.3, $P<0.05)$. The means of the within-subject relations between postprandial changes in hunger and fullness ratings, and postprandial changes in GLP-1, ghrelin, glucose, and insulin concentrations are shown in Figure 6.2. 


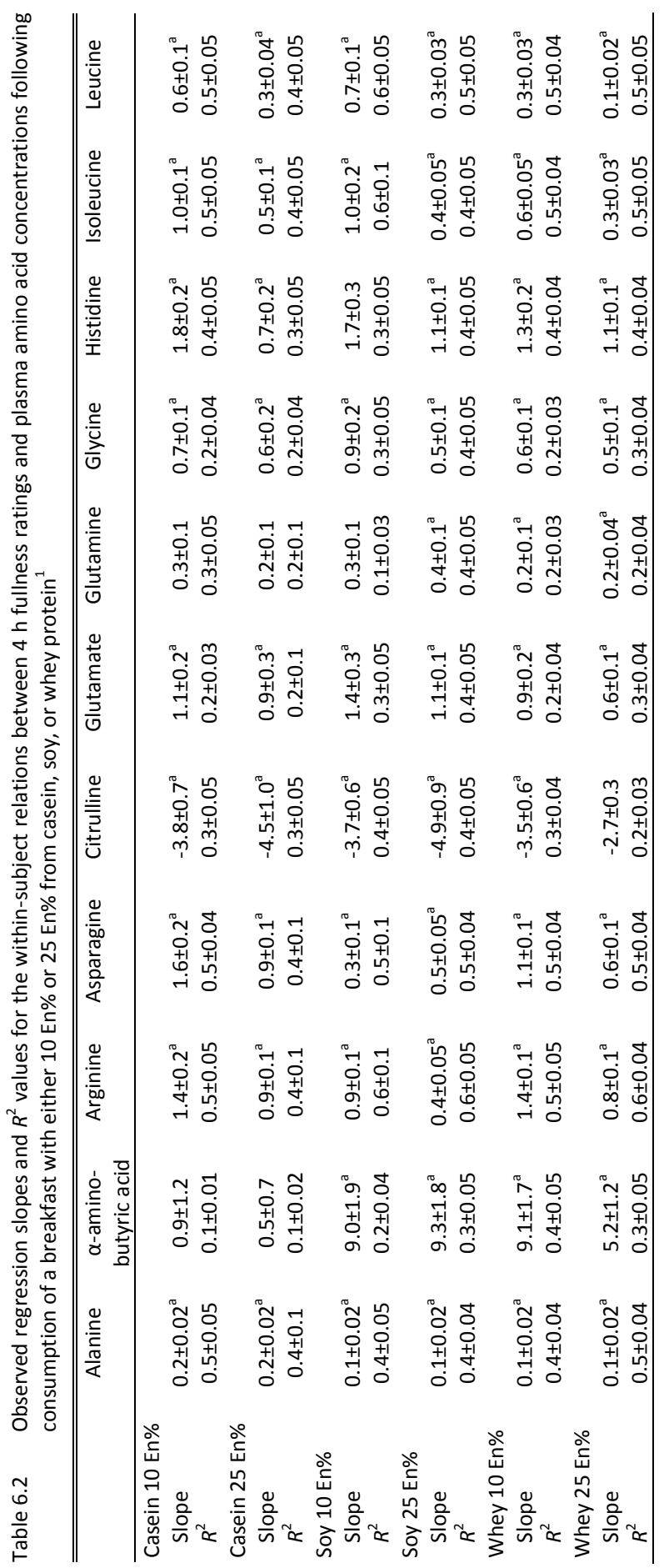




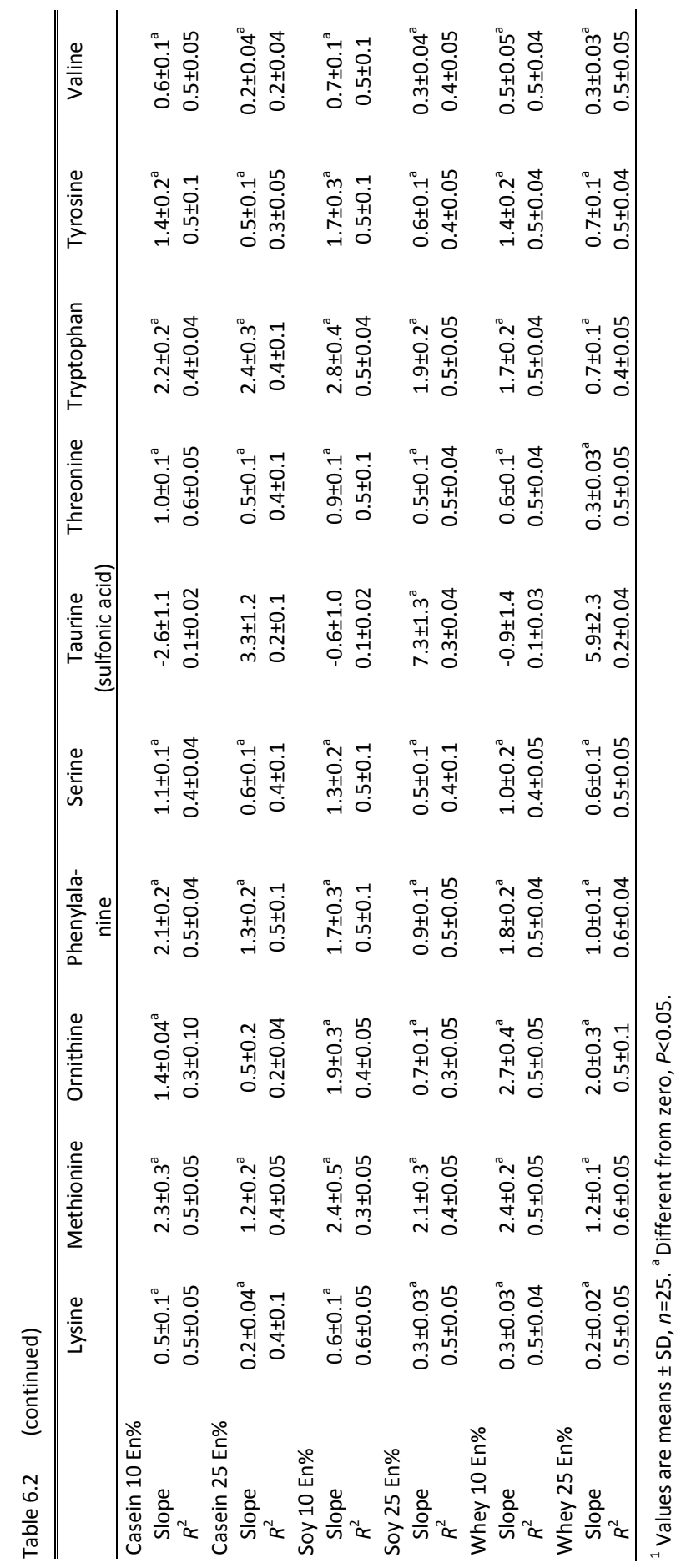



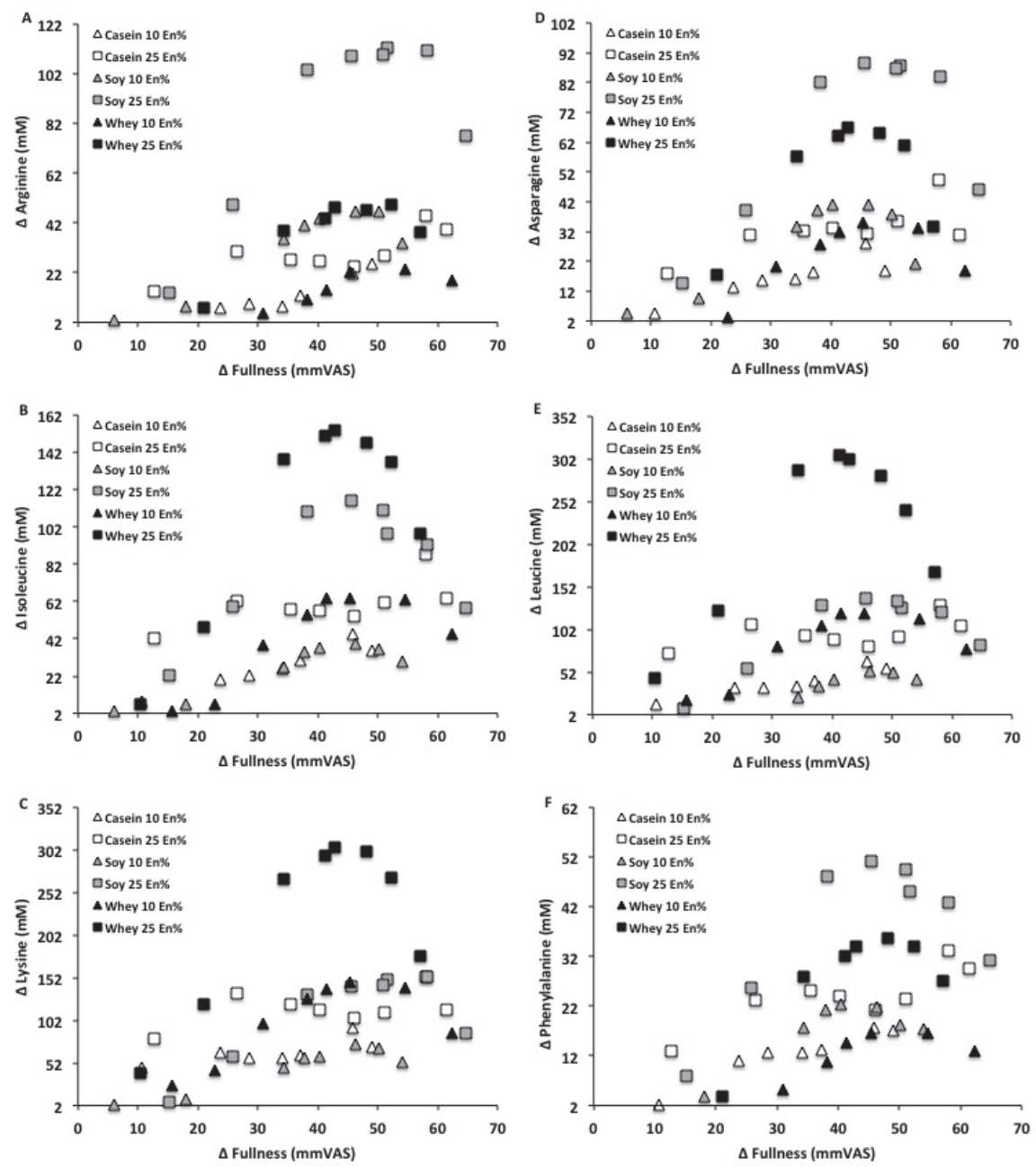

Figure 6.1 Means of the within-subject relations between postprandial fullness and arginine (A), asparagine (B), isoleucine (C), leucine (D), lysine $(E)$, and phenylalanine (F) for the corresponding measuring moments. Values are means, $n=25$; Regression slopes and $R^{2}$ values different from zero, $P<0.05$ for all amino acids. GLP-1, glucagon-like peptide 1 ; VAS, visual analog scale. 


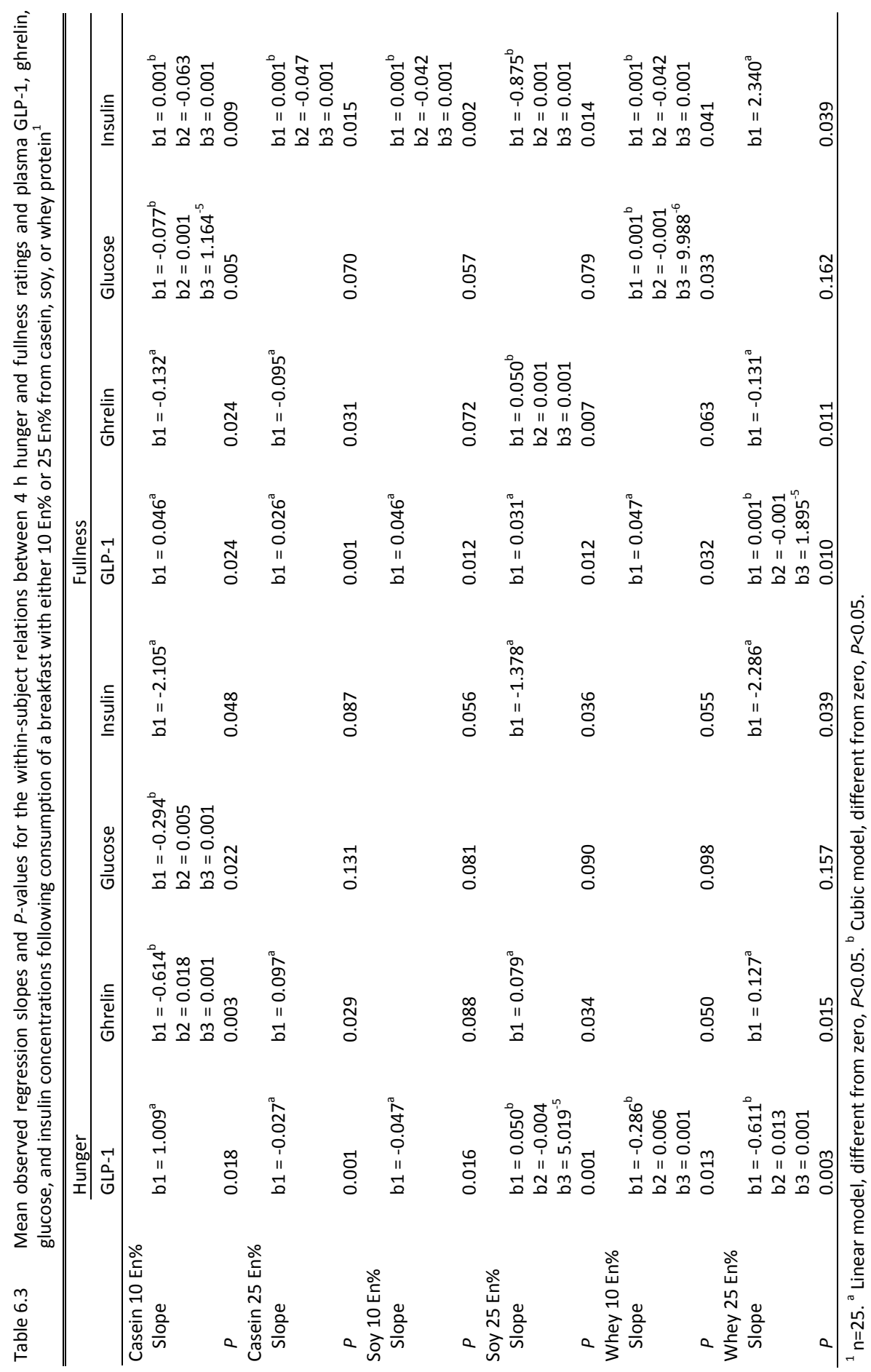



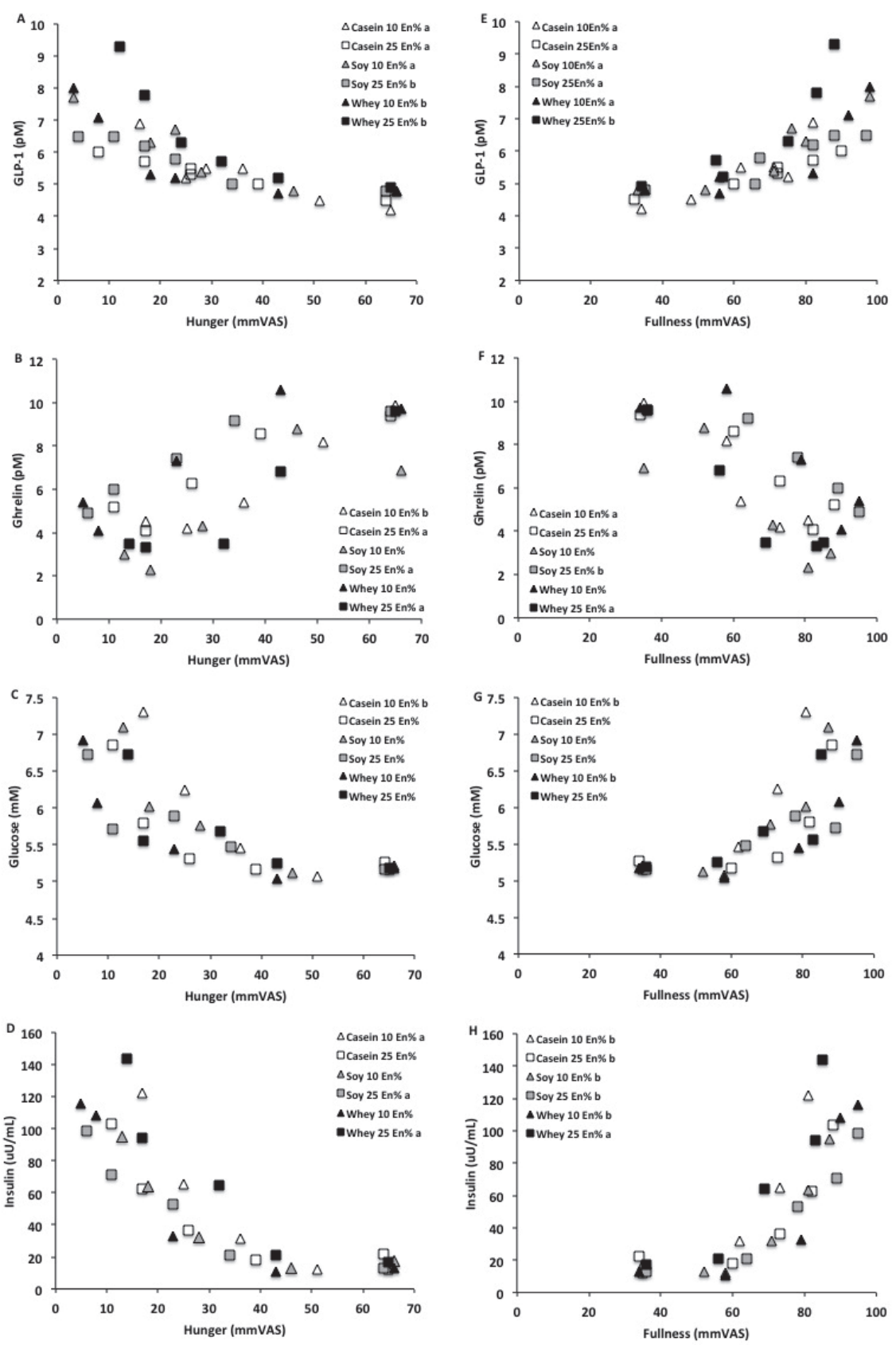

Figure 6.2 Means of the within-subject relations between postprandial hunger and GLP-1 (A), ghrelin $(B)$, glucose $(C)$, insulin $(D)$, and fullness and GLP-1 $(E)$, ghrelin $(F)$, glucose $(G)$, insulin $(H)$ for the corresponding measuring moments. Values are means, $n=25$; ${ }^{a}$ Linear model, different from zero, $P<0.05 ;{ }^{b}$ Cubic model, different from zero, $\left.P<0.05\right)$. GLP-1, glucagonlike peptide 1; VAS, visual analog scale. 


\section{DISCUSSION}

This study assessed the within-subject relations between postprandial changes in hunger and fullness and postprandial changes in amino acid, GLP-1, ghrelin, glucose, and insulin concentrations following the consumption of normal and high casein-, soy-, or whey-protein containing breakfasts. The aim was to find different associations that might relate to the observed differences in postprandial hunger and fullness between proteins as well as between different dosages of the same protein. Results showed that postprandial increases in fullness ratings were related to increases in plasma concentrations of most amino acids, irrespective of protein content and protein type. The amino acids arginine, asparagine, isoleucine, leucine, lysine, and phenylalanine showed a $R^{2}>50 \%$ following the consumption of breakfasts with $10 \mathrm{En} \%$ from casein-, soy-, or whey-protein, as well as with $25 \mathrm{En} \%$ from whey-protein. This indicates that increases in postprandial amino acid concentrations are related to protein-induced fullness, independent of the type of protein but rather with $10 \mathrm{En} \%$-protein meals than with $25 \mathrm{En} \%$-protein meals. The observations that the magnitude of the explained variation in fullness of these amino acids was less with breakfasts comprising a larger protein content from casein or soy suggest that these amino acids may be important for protein-induced fullness at lower protein contents. Prolonged elevations of amino acid concentrations, and differences in the peaks of the different amino acids, may have contributed to the lower order of magnitude of the explained variation at $25 \mathrm{En} \%$ of protein.

The effects of single amino acids on protein-induced fullness have been studied before. A leucine-supplemented diet led to a similar decrease in food intake and body weight as a high-protein diet $(24,25)$. Furthermore, leucine administration directly in the central nervous system decreased food intake in a dose-dependent manner, which was not observed with other amino acids $(24,25)$. Leucine has been shown to activate the mammalian target of rapamycin (mTOR) pathway within the mediobasal hypothalamus, and possibly also within the nucleus tractus solitarus of the brain stem (26). Leucine has also been observed to inhibit the hypothalamic 5 'adenosine monophosphate-activated protein kinase pathway (25), a pathway that also interacts with the mTOR pathway (27), thereby modulating hypothalamic neuropeptides. Subsequent activation of catabolic pro-opiomelanocortin neuron activity and inactivation of anabolic neuropeptide $\mathrm{Y} /$ Agouti-related peptide neurons in the arcuate nucleus of the hypothalamus induce a reduction of food intake. These two neuronal circuits are balanced and partly control food intake (28). Furthermore, leucine and isoleucine are two of the three branched-chain amino acids that may regulate protein synthesis and degradation, as well as insulin secretion and synthesis (29-31). The high-energy costs of these processes may be related to satiety $(32,33)$. 
With respect to lysine, it was shown that its consumption induced a mild satiety effect (34). Arginine is a semi-essential amino acid and known to increase growth hormone release on the hypothalamic level $(35,36)$. Growth hormone increases protein synthesis by enhancing amino acid uptake (37). Moreover, arginine is the direct precursor of nitric oxide (38), which was reported to be an important regulator of gastrointestinal motility and emptying (39). Phenylalanine is an essential amino acid whose effects on satiety are thought to be potent by controlling the release of cholecystokinin, and stimulating a rise in insulin and glucagon concentrations, while controlling glucose metabolism $(40,41)$.

In general, dietary amino acids affect satiety signaling in the brain indirectly via innervation of vagal afferent fibers or changes in gut hormone secretion and directly via increased postprandial plasma concentrations $(2,42)$. The 'aminostatic theory' suggests that elevated serum amino acid concentrations, which cannot be channeled into protein synthesis, serve as satiety signals in the central nervous system and thereby result in suppressed food intake (4).

The changes in the postprandial concentrations of GLP-1, insulin, and ghrelin were related to the changes in hunger and fullness ratings, although for ghrelin and insulin sometimes as trends. Glucose concentrations showed less strong relations with hunger and fullness, probably due to the faster kinetics of the responses.

With respect to the different proteins, it was shown before that a $25 \mathrm{En} \%$-casein breakfast was more satiating than a 10En\%-casein breakfast (8). Now this observation is underscored by the relations between changes in hunger and the changes in GLP-1 and ghrelin concentrations. Similarly, a breakfast containing $25 \mathrm{En} \%$ from soy was reported to be more satiating than a breakfast with $10 \mathrm{En} \%$ from soy, which was related to elevated concentrations of taurine (7). In the present analysis, changes in hunger ratings following the consumption of soycontaining breakfasts were related to the changes in GLP-1- and insulinconcentrations. Lastly, whey-protein was more satiating than casein or soy at $25 \mathrm{En} \%$, which was underscored by larger isoleucine, leucine, lysine, threonine, and tryptophan responses (5). With the present analyses, these responses partly coincide with the relations with the amino acids arginine, asparagine, isoleucine, leucine, lysine, and phenylalanine, and with GLP-1, ghrelin and insulin. From these relations we observe that the within-subject correlations add to the explanation of the earlier observed differences in protein-induced fullness. The dissimilar effects of whey protein compared with casein or soy protein may be related to whey being more satiating than casein and soy protein.

To conclude, postprandial kinetics of arginine, asparagine, isoleucine, leucine, lysine, and phenylalanine were related to casein-, soy, and whey-protein-induced fullness especially at $10 \mathrm{En} \%$ of protein, while the postprandial kinetics of GLP-1, ghrelin, and insulin were also related to changes in appetite at $25 \mathrm{En} \%$ of these proteins. 


\section{ACKNOWLEDGEMENTS}

We thank MAV to give us the opportunity to further analyze the data, which was previously collected and published in peer-reviewed journals (5,7-9). 


\section{REFERENCES}

1. Veldhorst MA, Westerterp-Plantenga MS, Westerterp KR. Gluconeogenesis and energy expenditure after a high-protein, carbohydrate-free diet. Am J Clin Nutr 2009;90:519-26.

2. Morrison CD, Reed SD, Henagan TM. Homeostatic regulation of protein intake: in search of a mechanism. Am J Physiol Regul Integr Comp Physiol 2012;302:R917-28.

3. Veldhorst M, Smeets A, Soenen S, Hochstenbach-Waelen A, Hursel R, Diepvens K, Lejeune M, Luscombe-Marsh N, Westerterp-Plantenga M. Protein-induced satiety: effects and mechanisms of different proteins. Physiol Behav 2008;94:300-7.

4. Mellinkoff SM, Frankland M, Boyle D, Greipel M. Relationship between serum amino acid concentration and fluctuations in appetite. J Appl Physiol 1956;8:535-8.

5. Veldhorst MA, Nieuwenhuizen AG, Hochstenbach-Waelen A, van Vught AJ, Westerterp KR, Engelen MP, Brummer RJ, Deutz NE, Westerterp-Plantenga MS. Dose-dependent satiating effect of whey relative to casein or soy. Physiol Behav 2009;96:675-82.

6. Hall WL, Millward DJ, Long SJ, Morgan LM. Casein and whey exert different effects on plasma amino acid profiles, gastrointestinal hormone secretion and appetite. Br J Nutr 2003;89:239-48.

7. Veldhorst MA, Nieuwenhuizen AG, Hochstenbach-Waelen A, Westerterp KR, Engelen MP, Brummer RJ, Deutz NE, Westerterp-Plantenga MS. Effects of high and normal soyprotein breakfasts on satiety and subsequent energy intake, including amino acid and 'satiety' hormone responses. Eur J Nutr 2009;48:92-100.

8. Veldhorst MA, Nieuwenhuizen AG, Hochstenbach-Waelen A, Westerterp KR, Engelen MP, Brummer RJ, Deutz NE, Westerterp-Plantenga MS. Comparison of the effects of a high- and normal-casein breakfast on satiety, 'satiety' hormones, plasma amino acids and subsequent energy intake. Br J Nutr 2009;101:295-303.

9. Veldhorst MA, Nieuwenhuizen AG, Hochstenbach-Waelen A, Westerterp KR, Engelen MP, Brummer RJ, Deutz NE, Westerterp-Plantenga MS. Effects of complete whey-protein breakfasts versus whey without GMP-breakfasts on energy intake and satiety. Appetite 2009;52:388-95.

10. Acheson KJ, Blondel-Lubrano A, Oguey-Araymon S, Beaumont M, Emady-Azar S, Ammon-Zufferey C, Monnard I, Pinaud S, Nielsen-Moennoz C, Bovetto L. Protein choices targeting thermogenesis and metabolism. Am J Clin Nutr 2011;93:525-34.

11. Delzenne N, Blundell J, Brouns F, Cunningham K, De Graaf K, Erkner A, Lluch A, Mars M, Peters HP, Westerterp-Plantenga M. Gastrointestinal targets of appetite regulation in humans. Obes Rev 2010;11:234-50.

12. Verdich C, Flint A, Gutzwiller JP, Naslund E, Beglinger C, Hellstrom PM, Long SJ, Morgan LM, Holst $\mathrm{JJ}$, Astrup A. A meta-analysis of the effect of glucagon-like peptide-1 (7-36) amide on ad libitum energy intake in humans. J Clin Endocrinol Metab 2001;86:4382-9.

13. Druce MR, Neary NM, Small CJ, Milton J, Monteiro M, Patterson M, Ghatei MA, Bloom SR. Subcutaneous administration of ghrelin stimulates energy intake in healthy lean human volunteers. Int J Obes (Lond) 2006;30:293-6.

14. Druce MR, Wren AM, Park AJ, Milton JE, Patterson M, Frost G, Ghatei MA, Small C, Bloom SR. Ghrelin increases food intake in obese as well as lean subjects. Int J Obes (Lond) 2005;29:1130-6.

15. Flint A, Gregersen NT, Gluud LL, Moller BK, Raben A, Tetens I, Verdich C, Astrup A. Associations between postprandial insulin and blood glucose responses, appetite sensations and energy intake in normal weight and overweight individuals: a meta-analysis of test meal studies. $\mathrm{Br} \mathrm{J} \mathrm{Nutr}$ 2007;98:17-25.

16. Thorens B. Glucose sensing and the pathogenesis of obesity and type 2 diabetes. Int J Obes (Lond) 2008;32 Suppl 6:S62-71.

17. Harris JA, Benedict FG. A Biometric Study of Human Basal Metabolism. Proc Natl Acad Sci U S A 1918;4:370-3.

18. Stunkard AJ, Messick S. The three-factor eating questionnaire to measure dietary restraint, disinhibition and hunger. J Psychosom Res 1985;29:71-83.

19. Munro HN. Second Boyd Orr Memorial Lecture. Regulation of body protein metabolism in relation to diet. Proc Nutr Soc 1976;35:297-308. 
20. Baecke JA, Burema J, Frijters JE. A short questionnaire for the measurement of habitual physical activity in epidemiological studies. Am J Clin Nutr 1982;36:936-42.

21. Westerterp KR, Kester AD. Physical activity in confined conditions as an indicator of free-living physical activity. Obes Res 2003;11:865-8.

22. van Eijk HM, Rooyakkers DR, Deutz NE. Rapid routine determination of amino acids in plasma by high-performance liquid chromatography with a 2-3 microns Spherisorb ODS II column. J Chromatogr 1993;620:143-8.

23. Lemmens SG, Martens EA, Born JM, Martens MJ, Westerterp-Plantenga MS. Staggered meal consumption facilitates appetite control without affecting postprandial energy intake. J Nutr 2011;141:482-8.

24. Blouet C, Schwartz GJ. Hypothalamic nutrient sensing in the control of energy homeostasis. Behav Brain Res 2010;209:1-12.

25. Ropelle ER, Pauli JR, Fernandes MF, Rocco SA, Marin RM, Morari J, Souza KK, Dias MM, GomesMarcondes MC, Gontijo JA, et al. A central role for neuronal AMP-activated protein kinase (AMPK) and mammalian target of rapamycin (mTOR) in high-protein diet-induced weight loss. Diabetes 2008;57:594-605.

26. Cota D, Proulx K, Smith KA, Kozma SC, Thomas G, Woods SC, Seeley RJ. Hypothalamic mTOR signaling regulates food intake. Science 2006;312:927-30.

27. Pimentel GD, Ropelle ER, Rocha GZ, Carvalheira JB. The role of neuronal AMPK as a mediator of nutritional regulation of food intake and energy homeostasis. Metabolism 2013;62:171-8.

28. Davidenko O, Darcel N, Fromentin G, Tome D. Control of protein and energy intake - brain mechanisms. Eur J Clin Nutr 2013;67:455-61.

29. Lynch CJ, Patson BJ, Anthony J, Vaval A, Jefferson LS, Vary TC. Leucine is a direct-acting nutrient signal that regulates protein synthesis in adipose tissue. Am J Physiol Endocrinol Metab 2002;283:E503-E13.

30. Kalogeropoulou D, LaFave L, Schweim K, Gannon MC, Nuttall FQ. Leucine, when ingested with glucose, synergistically stimulates insulin secretion and lowers blood glucose. Metabolism 2008;57:1747-52.

31. Nuttall FQ, Schweim K, Gannon MC. Effect of orally administered isoleucine with and without glucose on insulin, glucagon and glucose concentrations in non-diabetic subjects. E Spen Eur E J Clin Nutr Metab 2008;3:e152-e8.

32. Layman DK, Walker DA. Potential Importance of Leucine in Treatment of Obesity and the Metabolic Syndrome. J Nutr 2006;136:319S-23S.

33. Westerterp-Plantenga MS, Rolland V, Wilson SA, Westerterp KR. Satiety related to $24 \mathrm{~h}$ dietinduced thermogenesis during high protein/carbohydrate vs high fat diets measured in a respiration chamber. Eur J Clin Nutr 1999;53:495-502.

34. Kalogeropoulou D, LaFave L, Schweim K, Gannon MC, Nuttall FQ. Lysine ingestion markedly attenuates the glucose response to ingested glucose without a change in insulin response. Am J Clin Nutr 2009;90:314-20.

35. Collier SR, Casey DP, Kanaley JA. Growth hormone responses to varying doses of oral arginine. Growth Horm IGF Res 2005;15:136-9.

36. van Vught AJAH, Nieuwenhuizen AG, Brummer R-JM, Westerterp-Plantenga MS. Effects of Oral Ingestion of Amino Acids and Proteins on the Somatotropic Axis. J Clin Endocrinol Metab 2008;93:584-90.

37. Moller N, Vendelbo MH, Kampmann U, Christensen B, Madsen M, Norrelund H, Jorgensen JO. Growth hormone and protein metabolism. Clin Nutr 2009;28:597-603.

38. Fiorucci S, Distrutti E, Quintieri A, Sarpi L, Spirchez Z, Gulla N, Morelli A. L-arginine/nitric oxide pathway modulates gastric motility and gallbladder emptying induced by erythromycin and liquid meal in humans. Dig Dis Sci 1995;40:1365-71.

39. Boeckxstaens GE, Pelckmans PA. Nitric oxide and the non-adrenergic non-cholinergic neurotransmission. Comp Biochem Physiol A Physiol 1997;118:925-37.

40. Ballinger $A B$, Clark ML. I-Phenylalanine releases cholecystokinin (CCK) and is associated with reduced food intake in humans: Evidence for a physiological role of CCK in control of eating. Metabolism 1994;43:735-8. 
41. Rogers PJ, Blundell JE. Reanalysis of the effects of phenylalanine, alanine, and aspartame on food intake in human subjects. Physiol Behav 1994;56:247-50.

42. Fromentin G, Darcel N, Chaumontet C, Marsset-Baglieri A, Nadkarni N, Tome D. Peripheral and central mechanisms involved in the control of food intake by dietary amino acids and proteins. Nutr Res Rev 2012;25:29-39. 


\section{CHAPTER 7}

Maintenance of energy expenditure on high-protein vs. high-carbohydrate diets at a constant body weight may prevent a positive energy balance

Martens EA, Gonnissen HK, Gatta-Cherifi B, Janssens PL, Westerterp-Plantenga MS

Submitted 


\section{ABSTRACT}

\section{Background \& aims}

Relatively high-protein diets are effective for body weight loss, and subsequent weight maintenance, yet it remains to be shown whether these diets would prevent a positive energy balance. Therefore, high-protein diet studies at a constant body weight are necessary. The objective was to determine fullness, energy expenditure, and macronutrient balances on a high-protein low-carbohydrate (HPLC) diet compared with a highcarbohydrate low-protein (HCLP) diet at a constant body weight, and to assess whether effects are transient or sustained after 12 weeks.

\section{Methods}

A randomized parallel study was performed in 14 men and 18 women [mean \pm SD age: $24 \pm 5 \mathrm{y} ; \mathrm{BMI}$ (in $\mathrm{kg} / \mathrm{m}^{2}$ ): $22.8 \pm 2.0$ ] on diets containing 30:35:35 (HPLC) or 5:60:35 (HCLP) \% of energy from protein:carbohydrate:fat.

\section{Results}

Significant interactions between dietary intervention and time on total energy expenditure (TEE) $(P=0.013)$, sleeping metabolic rate (SMR) $(P=0.040)$, and diet-induced thermogenesis (DIT) $(P=0.027)$ appeared from baseline to $w k 12$. TEE was maintained in the HPLC diet group, while it significantly decreased throughout the intervention period in the HCLP-diet group (wk 1: $P=0.002$; wk 12: $P=0.001$ ). Energy balance was maintained in the HPLC diet group, and became positive in the HCLP diet group at wk $12(P=0.008)$. Protein balance varied directly according to the amount of protein in the diet, and diverged significantly between the diets $(P=0.001)$. Fullness ratings were significantly higher in the HPLC vs. the HCLP-diet group at wk $1(P=0.034)$.

\section{Conclusions}

Maintenance of energy expenditure on HPLC vs. HCLP diets at a constant body weight may prevent development of a positive energy balance. The study was registered on clinicaltrials.gov with Identifier: NCT01551238. 


\section{INTRODUCTION}

High-protein diets appear to show different effects in relation to energy balance. Considering the increasing prevalence of overweight and obesity, energy-restricted and ad libitum high-protein diets have come into focus as being a beneficial strategy for body weight loss, and weight maintenance thereafter (1-4). Most remarkable long-term effects are shown when relatively high-protein diets are consumed in negative energy balance achieved by restriction of carbohydrate and fat intake, but not of protein intake. The potential of these diets to maintain a negative energy balance, to induce body weight loss, and to maintain the lower body weight, can be explained by a sustained satiety at the level of the original diet $(5,6)$, and a sustained energy expenditure, which is underscored by preservation of fat-free mass (FFM) $(7,8)$. However, the question remains whether these effects, observed for high-protein diets in negative energy balance, can be translated into preventive measures for body weight gain when consumed in neutral, or even in positive energy balance. A positive energy balance induced by overfeeding with a high-protein diet was shown to result in a significant body weight gain. In a situation with low physical activity, fat mass as well as FFM were increased, together with an increase in resting energy expenditure (9). Resistance training combined with a high-protein diet in positive energy balance showed an apparent effect on FFM accretion (10). The acute effects of high protein intake combined with resistance training on muscle protein synthesis are assumed to be predictive for high-protein diets stimulating muscle hypertrophy in the longer-term (11-13).

Studies at a constant body weight, where energy balance can be neutral in principle, but may fluctuate between days (14), could be used to predict whether protein intake plays a role in the development of overweight and obesity. The results of a systematic review of epidemiological studies suggest that protein intake was neither associated with body weight gain or obesity, nor with body weight loss; moreover, the observations are inconsistent (15). Recently, it was suggested that the differential effects of protein intake are due to differences in protein source (16). Furthermore, it has been observed that protein intake is maintained within a small range across populations and over time (17).

Short-term intervention studies using energy-balanced diets with large contrasts in relative protein content have shown that high-protein diets induce increased satiety compared with diets lower in protein, at least over 24 hours $(5,18-23)$. Furthermore, higher rates of energy expenditure $(24,25)$, a positive protein balance $(21,24,26)$ and an initial negative energy balance $(24)$ were observed in response to these energy-balanced high-protein diets. However, it is unclear whether the observed effects from these acute studies are transient or sustained, thus implying prevention of body weight gain. In order to assess whether a high-protein diet would be a concept for prevention of a positive energy balance, we carried out a dietary intervention study to determine fullness, energy 
expenditure, and macronutrient balances on a high-protein low-carbohydrate (HPLC) diet compared with a high-carbohydrate low-protein (HCLP) diet at a constant body weight, and assessed whether effects are transient or sustained after 12 weeks.

\section{MATERIALS AND METHODS}

The Medical Ethical Committee of Maastricht University approved the study, and all subjects gave written informed consent. The study was registered on clinicaltrials.gov with Identifier: NCT01551238.

\section{Study subjects}

Sensitivity analysis on data from a respiration chamber study by Westerterp et al. (27) for the difference in 24-h diet-induced thermogenesis (DIT) between 29En\% and $9 E n \%$-protein diets showed that the effect size was 0.391 . Based on this effect size, with an $\alpha$ of 0.05 and a $b$ of 0.10 , sample size calculation showed that at least 16 subjects per group were needed to show an interaction effect of dietary intervention and time on 24-h DIT in this study.

Forty-two subjects were recruited by advertisements in local newspapers and on notice boards at the university, of whom five dropped out due to lack of time. Five subjects had to be excluded from the data analysis because of non-compliance with the designated protein intake, as shown by the urinary nitrogen biomarker. Metabolic parameters of one subject were missing. Thus, 32 subjects (14 men and 18 women) were included in the final data analysis, and 31 subjects (14 men and 17 women) in the analysis of metabolic parameters.

Subjects underwent a screening that included anthropometric measurements and the completion of questionnaires eliciting information about health, smoking behaviour, use of medications, alcohol consumption, physical activity, eating behaviour and palatability of the study foods. Subjects were normal weight or slightly overweight [BMI range (in $\mathrm{kg} / \mathrm{m}^{2}$ ): 19.2-26.1 and aged between 19 and $34 \mathrm{y}$. $\mathrm{BMI}$ and age were equally divided between males and females. Waist circumference was measured at the smallest circumference between the rib cage and iliac crest, and hip circumference at the level of the spina iliaca anterior superior. Subjects were non-smoking, not using more than moderate amounts of alcohol ( $>10$ drinks/wk), were weight stable (body weight change $<3 \mathrm{~kg}$ during the last 6 mo and had no planned weight change during the study period), and were not using medication or supplements except for oral contraceptives in women.

The validated Dutch translation of the Baecke Activity Questionnaire was used to measure habitual physical activity scores, which were subsequently converted into a standardized individual physical activity level $(28,29)$. Eating behaviour was 
analyzed using a validated Dutch translation of the Three-Factor Eating Questionnaire, which measures the 3 factors involved in eating behaviour, namely 'cognitive restraint of eating, 'disinhibition of restraint', and 'hunger' $(30,31)$.

Protein and carbohydrate shakes were served and tested on palatability by 100-mm visual analog scales (VAS) anchored with 'not at all' at one end and 'extremely' at the other end. Only subjects who rated the shakes as sufficiently palatable (VAS score $\geq 50 \mathrm{~mm}$ ), and who were confident of being able to consume these daily during the study period were included in the study.

\section{Dietary intervention}

This study used a single-blind parallel design comprising short- and longer-term intervention periods with diets differing in relative protein content. Two days before the baseline measurement in a respiration chamber, all subjects were provided with an energy-balanced diet containing a normal relative protein content (15:50:35\% of energy (En\%) from protein:carbohydrate:fat). Individual daily energy requirements (DER) were calculated as the basal metabolic rate determined with the formula of Harris and Benedict (32) times the individual physical activity level. During the 48-h baseline measurement, a diet with a similar macronutrient composition was served, whereby the physical activity level was estimated to be 1.35 for subjects being in energy balance. Subsequently, subjects were randomly allocated to the HPLC (30:35:35En\% from protein:carbohydrate:fat) or the HCLP (5:60:35En\%) diet group by stratification on sex, age and BMI. Protein was completely exchanged with carbohydrate, resulting in a relative fat content being similar in the baseline-, the HPLC- and the HCLP diets. Subjects were instructed to maintain a stable body weight throughout the complete period of 12 weeks. Therefore, they received detailed dietary guidelines based on individual DER. The dietary guidelines consisted of a variety of recipes for breakfasts, lunches, dinners and snacks, including the food items and the amounts that had to be consumed. The HPLC and HCLP diets were comparable, and consisted of commercially available food items. The guidelines included the prescription to consume additional protein [HPLC: whey with $\alpha$-lactalbumin (Hiprotal Whey Protein Alpha, FrieslandCampina Domo EMEA, Amersfoort, The Netherlands)] or carbohydrate [HCLP: maltodextrin (Fantomalt, Nutricia, Zoetermeer, The Netherlands)] by shakes twice daily. Subjects had to consume the shakes in addition to the dietary changes to ensure they reached the intended diet compositions that were difficult to reach with only commercially available food items. The 48-h measurements in the respiration chamber were repeated after 1 week (short-term) and after 12 weeks (longer-term), whereby subjects received energy-balanced diets corresponding to their diet group. Daily energy intake was divided over three meals, with breakfast containing $20 \%$, and lunch and dinner $40 \%$. During all measurements in the respiration chamber, the meals within each condition had the same macronutrient composition. Furthermore, the incorporation of the protein and carbohydrate 
powders in the meals enabled to keep all food items and the energy density, weight and volume of the meals the same between the baseline diet, the HPLC, and the HCLP diets.

Diets were composed using nutrition information on the food items and from standard food-composition tables (Dutch Food Composition Table Stichting Nederlands Voedingsstoffenbestand, Utrecht, The Netherlands). During the respiration chamber measurements, breakfast was composed of breakfast cereals (Kellogg's Nederland, 's Hertogenbosch, The Netherlands) moistened with orange juice. Lunch consisted of bread with butter and cucumber salad, served with protein or carbohydrate shakes corresponding to diet group. Dinner meal included pasta with oil, vegetables and tomato sauce. Subjects were allowed to drink water ad libitum between the meals, but no other foods or beverages were allowed to be consumed. At weeks 5 and 9 of the intervention period, interim visits were scheduled to monitor compliance to the dietary guidelines.

\section{Biomarker of protein intake}

Nitrogen excretion, measured from 24-h urine collections during the respiration chamber measurements at baseline, and at weeks 1 and 12, and before the interim visits at weeks 5 and 9, was used as an estimate of protein intake. Urine was collected in 2-I urine bottles containing $10 \mathrm{ml}$ of diluted hydrochloric acid $(4 \mathrm{mmol} / \mathrm{l})$ to prevent nitrogen loss through evaporation. The total volume of the 24-h urine was recorded. Urine was gently mixed, and samples were taken and frozen at $-20^{\circ} \mathrm{C}$ until analysis. Nitrogen concentrations were measured with an elemental analyser (CHN-O-Rapid, Heraeus, Hanau, Germany, in the Netherlands, and Integra COBAS 400 plus, Roche Diagnostics $\mathrm{GmbH}$, Rotkreuz, Switzerland, in the USA). Total nitrogen output was calculated as $24-\mathrm{h}$ urinary nitrogen plus $10 \%$ to account for normal losses via faeces and other miscellaneous losses.

\section{Body weight and body composition}

Body weight and adipose tissue volume were determined with subjects in the fasted state, at equivalent times in the morning at baseline and after the 12-wk intervention. Total adipose tissue volume was obtained by means of air displacement plethysmography (BOD POD, Life Measurement Inc., Concord, CA, USA), and from the measurement of total body water using the deuterium dilution method according to the Maastricht protocol (33). FFM was obtained by subtracting adipose tissue volume from body weight. During the interim visits at weeks 5 and 9 , body weight was measured in order to determine whether it remained constant. 


\section{Energy expenditure and substrate oxidation}

The respiration chamber measurements started at 20:00h (day 0), and stopped at 20:00h two days later (day 2). The respiration chamber is an airtight chamber of 14 $\mathrm{m}^{3}$ furnished with a bed, chair, desk with computer, TV, telephone, intercom, sink and toilet. The climate inside the chamber was controlled. $\mathrm{O}_{2}$ consumption and $\mathrm{CO}_{2}$ production were continuously measured by open-circuit ventilated indirect calorimetry. The room was ventilated with fresh air at a rate of 70-80 I/min. Flow was measured using electronically modified dry gasmeters (G6, gasmeterfabriek Schlumberger, Dordrecht, The Netherlands). The concentrations of $\mathrm{O}_{2}$ and $\mathrm{CO}_{2}$ were measured with dual pairs of infrared $\mathrm{CO}_{2}$ analyzers (ABB/Hartman\&Braun Uras, Frankfurt a.M, Germany) and paramagnetic $\mathrm{O}_{2}$ analyzers (Servomex 4100, Crowborough, England and ABB/Hartman\&Braun Magnos, Frankfurt a.M, Germany). During each 15-min period, six samples of outgoing air, one sample of fresh air, zero gas and calibration gas were measured. The gas samples to be measured were selected by a computer that also stored and processed the data (34). Physical activity was continuously measured by means of a radar system. The unit emits a radar signal of constant frequency in the respiration chamber. The signal is reflected by the walls of the respiration chamber, and objects within it, and subsequently detected by a radar receiver working on the Doppler principle. The radar output is expressed as counts/min, which is proportional to the amount of movement of the subject in the respiration chamber. Airflow, noise and radio interferences do not interfere with the measured radar output (34).

Subjects had fixed bed times between 23:30h and 07:30h. In the daytime, they were not allowed to sleep or to perform exercise. Meals were offered at stated times (breakfast: 08:30h, lunch: 13:30h, dinner: 18:30h), and subjects were instructed to finish these within $30 \mathrm{~min}$.

Total energy expenditure (TEE) and the separate components of energy expenditure, sleeping metabolic rate (SMR), DIT, and activity energy expenditure (AEE) were calculated for the first and second 24-h interval during the 48-h stay in the respiration chamber. $\mathrm{O}_{2}$ consumption and $\mathrm{CO}_{2}$ production were used to calculate TEE according to the formula of Weir (35). SMR was expressed as the lowest mean TEE during three consecutive hours between 00:00h and 07:00h. The mean radar output corresponding with the SMR was assumed to represent the inactive state. Simple linear regression analysis based on the relationship between TEE and the corresponding radar output was used to calculate DIT and AEE. DIT was represented by the increase in energy expenditure relative to the energy expended during the assumed inactive state. AEE was calculated by subtracting SMR and DIT from TEE. Energy expended for thermoregulation was neglected, since subjects were staying in the respiration chamber in thermoneutral conditions. Energy balance was determined as the difference between energy intake and TEE.

The relationships between measured SMR at baseline and FFM at baseline were determined for the HPLC and HCLP diet groups. These equations were used to 
predict SMR in the different protein groups at week 12 by filling in the FFM values measured at week 12 . The ratios of measured SMR to predicted SMR were calculated as measures for adaptive thermogenesis. Adaptive thermogenesis is described as the decrease in SMR beyond what can be predicted by changes in FFM (36).

Respiratory quotient (RQ) was calculated by dividing $\mathrm{CO}_{2}$ production by $\mathrm{O}_{2}$ consumption as a measure of substrate oxidation. Specifically, the amount of protein oxidized was calculated from urinary nitrogen excretion. The difference between nitrogen intake and output was used to determine protein balance. The amounts of carbohydrate and fat oxidized were calculated from $\mathrm{CO}_{2}$ production, $\mathrm{O}_{2}$ consumption and protein oxidation with the formulas of Carpenter (37). Carbohydrate and fat balances were determined as the difference between intake and oxidation.

\section{Appetite profile}

Appetite profile was measured by means of VAS. These $100-\mathrm{mm}$ scales were anchored with 'not at all' at one end and 'extremely' at the other end, and combined with questions on feelings of hunger, satiety, fullness, and desire to eat. Subjects had to complete the VAS every hour during the daytime, and just before each meal during the 48-h that they stayed in the respiration chamber for the baseline measurement and for the measurements after week 1 and week 12 of the dietary intervention.

\section{Metabolic parameters}

Venous blood samples were collected in the fasted state on each morning during the measurements in the respiration chamber at 8:00h. Blood samples were distributed into EDTA tubes for the measurement of glucose, insulin and $\beta$-hydroxybutyrate concentrations. Blood samples were centrifuged at $4^{\circ} \mathrm{C}$ for $10 \mathrm{~min}$ at $3000 \mathrm{rpm}$. Plasma samples were stored at $-80^{\circ} \mathrm{C}$ until further analysis. Glucose concentrations were determined using the hexokinase method (ABX Penta Glucose HK CP reagens, Horiba ABX diagnostics, Montpellier, France). Insulin concentrations were measured by RIA (Human insulin specific RIA kit HI-14K, Merck Millipore, Darmstadt, Germany). Spectrophotometry was used for the determination of $\beta$-hydroxybutyrate concentrations (Ranbut kit, Randox Laboratories Ltd., Crumlin, County Antrim, UK).

\section{Statistical analysis}

SPSS version 20 for Macintosh OS X (SPSS Inc.) was used to perform statistical analyses. Data are presented as means \pm SDs. 
The AUC over the day was calculated for appetite ratings for hunger, fullness, satiety and desire to eat by using the trapezoidal method. Differences in subject characteristics, nitrogen excretion, body weight and body composition, energy expenditure and its components, substrate oxidation, appetite ratings, and metabolic parameters between the diet groups were assessed using Factorial ANOVA. Factorial ANOVAs with repeated measures were used to test whether nitrogen excretion, body weight and body composition, energy expenditure and its components, substrate oxidation, appetite ratings, and metabolic parameters changed over 1 week vs. baseline and over 12 weeks vs. baseline within the diet groups, and to test whether these effects differed between the diet groups. Bonferroni correction for multiple comparisons and post-hoc analyses was applied with all ANOVA tests. The relationships between measured TEE or SMR and FFM were determined using simple linear regression analysis. Differences were regarded as statistically significant if $P<0.05$.

\section{RESULTS}

\section{Subject characteristics}

Mean subject characteristics are displayed in Table 7.1. No significant differences were observed between the HPLC and HCLP diet groups at baseline. The subsets of subjects that were included for the measurement of energy expenditure were representative samples.

Table 7.1 Subject characteristics in the HPLC and HCLP diet groups

\begin{tabular}{lcc}
\hline \hline & HPLC & HCLP \\
\hline No. of subjects (M/F) & $15(7 / 8)$ & $17(7 / 10)$ \\
Age $(\mathrm{y})$ & $24 \pm 5^{\mathrm{a}, \mathrm{b}}$ & $24 \pm 5$ \\
Height $(\mathrm{cm})$ & $172 \pm 10$ & $172 \pm 9$ \\
Body weight $(\mathrm{kg})$ & $65.6 \pm 8.9$ & $67.9 \pm 9.2$ \\
WHR & $0.78 \pm 0.06$ & $0.80 \pm 0.06$ \\
FM (kg) & $13.9 \pm 5.0$ & $14.5 \pm 4.3$ \\
FFM (kg) & $51.7 \pm 11.7$ & $53.4 \pm 11.0$ \\
BMI (kg/m $\left.{ }^{2}\right)$ & $22.5 \pm 1.8$ & $23.2 \pm 2.1$ \\
BMR (MJ/d) & $6.7 \pm 1.0$ & $6.8 \pm 0.8$ \\
PAL & $1.8 \pm 0.1$ & $1.8 \pm 0.1$ \\
DER (MJ/d) & $12.2 \pm 1.7$ & $11.9 \pm 1.7$ \\
TFEQ Dietary restraint score & $5 \pm 3$ & $6 \pm 4$ \\
TFEQ Disinhibition score & $4 \pm 2$ & $4 \pm 2$ \\
TFEQ Hunger score & $4 \pm 2$ & $4 \pm 2$ \\
\hline
\end{tabular}

${ }^{a}$ Mean \pm SD (all such values). ${ }^{b}$ Values with different superscript letters are significantly different, $P<0.05$ (independent-samples t-test). BMR, basal metabolic rate; DER, daily energy requirement; FFM, fat-free mass; FM, fat mass; HCLP, high-carbohydrate low-protein; HPLC, high-protein low-carbohydrate; PAL, physical activity level; TFEQ, Three-Factor Eating Questionnaire; WHR, waist-to-hip ratio. 


\section{Biomarker of protein intake}

Baseline nitrogen excretion did not differ significantly between the HPLC $(11.8 \pm 3.2 \mathrm{~g} / \mathrm{d})$ and the HCLP $(12.2 \pm 3.4 \mathrm{~g} / \mathrm{d})$ diet groups. Nitrogen excretion increased significantly in the HPLC $(21.7 \pm 5.1 \mathrm{~g} / \mathrm{d}, P<0.05)$ and decreased significantly in the HCLP $(7.0 \pm 2.4 \mathrm{~g} / \mathrm{d}, P=0.001)$ diet group compared with baseline. Significant differences in protein intake between the diet groups were confirmed in that nitrogen excretion differed significantly between the diet groups throughout the intervention period $(P=0.001)$.

\section{Body weight and body composition}

Body weight remained stable during the 12-wk intervention period (Table 7.2). In the HPCL diet group, fat mass slightly decreased, and FFM slightly increased in response to the dietary intervention. Small increases in fat mass, coinciding with small decreases in FFM were observed in the HCLP diet group. These changes did not reach statistical significance in each of the diet groups.

Table 7.2 Body weight and body composition over 12 weeks in the HPLC $(n=15)$ and HCLP diet groups $(n=17)$

\begin{tabular}{lllll}
\hline \hline & \multicolumn{2}{c}{ Baseline } & \multicolumn{2}{c}{ Week 12 } \\
\cline { 2 - 5 } & \multicolumn{1}{c}{ HPLC } & HCLP & HPLC & HCLP \\
\hline Body weight (kg) & $65.6 \pm 8.9^{\mathrm{a}, \mathrm{b}}$ & $67.9 \pm 9.2$ & $65.6 \pm 8.5$ & $67.7 \pm 8.5$ \\
FM (kg) & $13.9 \pm 5.0$ & $14.5 \pm 4.3$ & $13.5 \pm 5.3$ & $14.9 \pm 5.1$ \\
FFM (kg) & $51.7 \pm 11.7$ & $53.4 \pm 11.0$ & $52.2 \pm 11.1$ & $52.8 \pm 10.2$ \\
\hline
\end{tabular}

${ }^{\mathrm{a}}$ Mean \pm SD (all such values). ${ }^{\mathrm{b}}$ Values with different superscript letters are significantly different, $P<0.05$ (independent-samples t-test). FFM, fat-free mass; FM, fat mass; HCLP, high-carbohydrate low-protein; HPLC, high-protein low-carbohydrate.

\section{Energy expenditure and substrate oxidation}

TEE and the separate components of energy expenditure; SMR, DIT, and AEE, were comparable between the HPLC and HCLP diet groups during the baseline measurement in the respiration chamber (Table 7.3). Significant interactions between dietary interventions over time on TEE $(P=0.013)$, SMR $(P=0.040)$, and DIT $(P=0.027)$ appeared from baseline to wk 12. TEE, SMR, and DIT were maintained throughout the intervention period on the HPLC diet. On the HCLP diet, these were significantly decreased at wk1 (TEE: $P=0.002$ ) and at wk 12 (TEE: $P=0.001$, SMR: $P=0.034$, DIT: $P=0.003)$. AEE was stable throughout the intervention period in both diet groups (Table 7.3). 


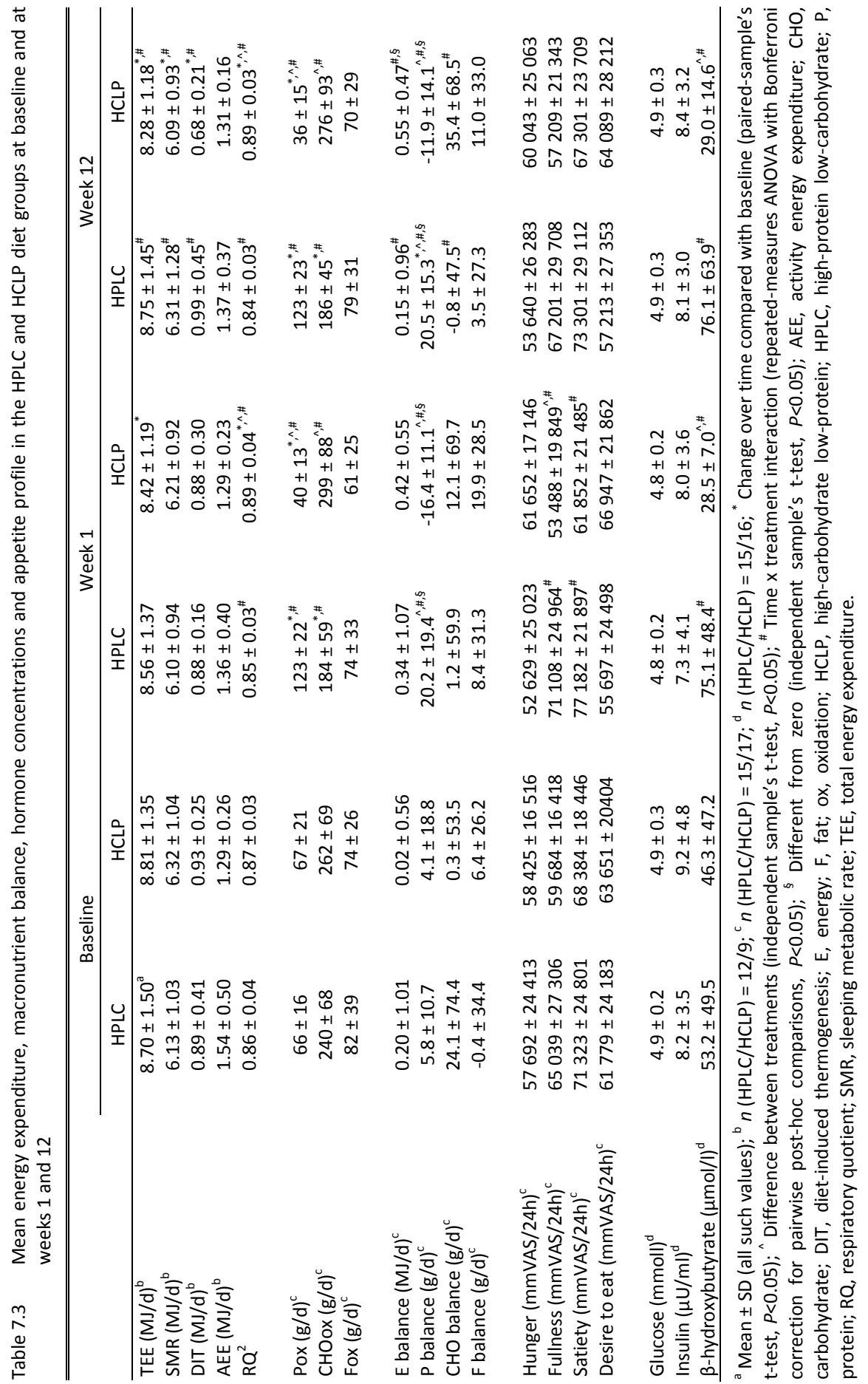


In both diet groups, SMR was linearly related to FFM at baseline (HPLC: $P=0.010$; HCLP: $P=0.001$ ) and at wk 12 (HPLC: $P=0.004$; HCLP: $P=0.001$ ). In the HPLC diet group, the slope of the regression line was increased at wk 12 vs. baseline $\left(\mathrm{SMR}_{\mathrm{wk} 12}=0.086 \mathrm{FFM}+1.75, R^{2}=0.60\right.$ vs. $\left.\mathrm{SMR}_{\text {baseline }}=0.072 \mathrm{FFM}+2.33, R^{2}=0.67\right)$. The slope of the regression line showed a similar pattern in the opposite direction in the HCLP diet group $\left(\mathrm{SMR}_{\mathrm{wk} 12}=0.085 \mathrm{FFM}+1.71, R^{2}=0.94 ; \mathrm{SMR}_{\text {baseline }}=0.089 \mathrm{FFM}\right.$ $+1.70, R^{2}=0.93$ ], indicating that SMR for a certain FFM were decreased at wk 12 vs. baseline. Measured and predicted SMR did not differ in the HPLC diet group after 12 weeks. In the HCLP diet group, measured SMR was significantly lower than the predicted value $(P=0.018)$. A trend for an effect of diet on the ratio of measured to predicted SMR $(P=0.070)$ was observed. The ratio was maintained throughout the intervention period on the HPLC diet. On the HCLP diet, the ratio of measured to predicted SMR was significantly decreased at wk 12 vs. baseline $(0.963 \pm 0.034$ vs. $1.001 \pm 0.056, P=0.017)$.

The rates for substrate oxidation did not significantly differ between the HPLC and HCLP diet groups during the baseline measurement (Table 7.3). Protein oxidation was significantly increased in the HPLC diet group, and was significantly decreased in the HCLP diet group at wk $1(P=0.001)$. These changes were sustained throughout the intervention period in both diet groups. In the HPLC diet group, carbohydrate oxidation showed a similar pattern in the opposite direction with rates being lower at wk $1(P=0.018)$ and at wk $12(P=0.022)$. Carbohydrate oxidation was significantly higher in the HCLP compared with the HPLC diet group at wk $1(P=0.002)$, which was sustained at wk $12(P=0.008)$. Fat oxidation did not change during the intervention period, irrespective of dietary intervention. Changes in substrate oxidation were reflected as RQ values being significantly lower in the HPLC compared with the HCLP diet group at wk $1(P=0.007)$ and at wk $12(P=0.005$, Table 7.3).

A significant interaction between dietary intervention over time on energy balance appeared from baseline to wk $12(P=0.013)$. Subjects in the HPLC diet group were in energy balance during all measurements in the respiration chamber. In contrast, subjects in the HCLP diet group were in positive energy balance during the measurement at wk $12(P=0.008)$, and a trend for a positive energy balance was already observed at wk $1(P=0.051$, Table 7.3). Protein balance varied directly according to the amount of protein in the diet $(P=0.001)$. Protein balance was positive in the HPLC diet group at wk $1(P=0.015)$ and at wk $12(P=0.001)$, in similar order of magnitude (Table 7.3). A similar pattern in the opposite direction was observed in the HCLP diet group (wk 1: $P=0.016$, wk 12: $P=0.047$ ). The significant interaction between dietary intervention and time on carbohydrate balance from baseline to wk 12 ( $P=0.038$, Table 7.3$)$ indicates prevention for the development of a positive energy balance in response to the HPLC vs. the HCLP diet (Table 7.3). 


\section{Appetite profile}

Ratings of hunger, satiety, fullness, and desire to eat were not significantly different between the HPLC and HCLP-diet groups at the moments that subjects entered the respiration chamber. Appetite ratings, expressed as mean AUC over the 48-h test periods, were also comparable between the diet groups during the baseline measurement (Table 7.3). Significant interactions between dietary intervention and time on ratings for fullness $(P=0.013)$ and satiety $(P=0.010)$, and a trend for an interaction on ratings for desire to eat $(P=0.068)$ appeared from baseline to wk 1 (Table 7.3). Small non-significant decreases in ratings of hunger and desire to eat, and small non-significant increases in ratings of satiety and fullness were observed in the HPLC diet group at wk 1, which were largely recovered during the measurement at wk 12. In the HCLP diet group, appetite ratings showed a similar pattern in the opposite direction, however also not reaching statistical significance. Mean AUC over the 48-h test period was significantly higher for appetite ratings of fullness $(P=0.034)$, and showed a trend for being higher for satiety $(P=0.055)$ in the HPLC compared with the HCLP-diet group at wk 1 (Table 7.3). The palatability of the meals was comparable between the conditions.

\section{Metabolic parameters}

At the 48-h baseline measurement, glucose and insulin concentrations were comparable between the HPLC and HCLP diet groups. Glucose and insulin concentrations did not significantly change during the intervention period in each of the diet groups. However, a trend for lower glucose concentrations at wk 12 compared with wk 1 was observed in the HPLC-diet group ( $P=0.068)$.

$\beta$-hydroxybutyrate concentrations did not differ between both diet groups at the 48-h baseline measurement. Significant interactions between dietary intervention and time on $\beta$-hydroxybutyrate concentrations appeared from baseline to wk $1 \quad(P=0.026)$ and wk $12 \quad(P=0.038)$, with $\beta$-hydroxybutyrate concentrations relatively increasing in the HPLC-diet group and decreasing in the HCLP-diet group. At wk 1 and 12, $\beta$-hydroxybutyrate concentrations were significantly higher in the HPLC compared with the HCLP-diet group $(P=0.003$, $P=0.009)$.

\section{DISCUSSION}

Relatively high-protein diets are effective for body weight loss, and subsequent weight maintenance, but no observations are available on whether these diets would prevent a positive energy balance. Therefore, high-protein diet studies at a constant body weight are necessary. In this dietary intervention study, in which subjects maintained their body weight, we observed initial, but transient effects on 
fullness, and sustained effects on energy expenditure and macronutrient balances on a HPLC diet vs. a HCLP diet. The observation that the condition of stable body weight was met in both diet groups confirmed that these effects were not affected by changes in body weight. The successful implementation of the dietary intervention in each diet group was confirmed by urinary nitrogen concentrations.

The HPLC and the HCLP diets differently influenced energy expenditure over 12 weeks, in that no change was observed in the HPLC diet group, whereas energy expenditure decreased in the HCLP diet group. SMR and DIT changed in opposite directions in response to the HPLC and HCLP diets, reaching statistical significance in the HCLP diet group after 12 weeks. The decrease in energy expenditure in the HCLP diet group was already observed after 1 week, and continued throughout the remaining intervention period. This response was completely underscored by decreases in SMR and DIT, which both showed a similar response pattern.

Body composition did not change over time within each diet group. However, small changes in FFM in opposite directions between the HPLC and HCLP diet groups are in line with the observed effects on SMR. High protein intake appears to be a strong stimulus for preservation of FFM, whereas low protein intake increases the susceptibility for a decrease in FFM. Correspondingly, FFM increased independently of body weight in a 12-week intervention study in which subjects were counseled to exchange $2 \mathrm{MJ}$ of their habitual energy intake with isocaloric protein supplements (38). Previous studies have reported that high protein intake stimulates protein synthesis and turnover, and induces a small suppression of protein breakdown (39-41). In the present study we observed that consumption of the HPLC diet did not translate into a clear increase in FFM in a situation of a constant body weight without strenuous exercise. Possibly, an external stimulus such as resistance exercise is necessary for high protein intake to induce protein anabolism $(13,42)$. Nevertheless, the small changes in FFM, and the stimulation of protein synthesis and protein turnover likely contribute to the explanation for the small increase in SMR. Furthermore, the high protein intake on the HPLC diet may have prevented adaptive thermogenesis to develop. Adaptive thermogenesis via a decrease in SMR did develop on the HCLP diet. These processes may have facilitated the development of a positive energy balance on the HCLP diet, which was present at week 12. HPLC diets may be beneficial to prevent a positive energy balance to develop.

The positive protein balance on the HPLC-diet was maintained throughout the intervention period, and the sustained positive nitrogen balance on the HPLC diet corresponds with earlier observations (43). Similarly, sustained nitrogen accretion with high-protein intake was shown in nitrogen balance studies, whereas no gain of body nitrogen was measured (44). A possible explanation is the retention or loss of body nitrogen due to a labile pool of body nitrogen (45). Remarkably, the positive protein balance throughout the intervention period only appeared in a slight, but not significant increase in FFM. A significant increase in FFM over 12 weeks on a 
high-protein diet has been observed before (38), in a study with only men, in relation to their habitual physical activity. That it was not observed in the present study may be due to the number of women included in this study, and the lower level of AEE. In the HCLP-diet group, the opposite had occurred. Protein-balance appeared to remain negative, and a slight decrease in FFM occurred, not reaching statistical significance.

Differential effects of dietary protein content on metabolic efficiency may contribute to the explanation for changes in DIT in opposite directions in response to the HPLC and HCLP diets. The metabolic efficiency is lower for protein compared with carbohydrate and fat. It was previously shown that DIT increased with $0.22 \pm 0.42 \%$ for each En\% increase in protein content in the range between $10 \mathrm{En} \%$ and $30 \mathrm{En} \%(46)$. The decreased protein oxidation in response to the lower protein intake on the HCLP diet, coinciding with a decrease in DIT suggests that extrapolation to low-protein diets is possible.

The sustained increase in RQ in the HCLP diet group reflects a consistently larger contribution of carbohydrates to the substrate oxidation. However, the amount of carbohydrates oxidized was not significantly increased, indicating that carbohydrates were not in excess to such an extent that oxidation rates were enhanced to expend this energy as heat $(47,48)$. Carbohydrate oxidation did show a sustained decrease in the HPLC diet group. Increases in protein oxidation likely contribute to the small increases in DIT in response to the HPLC diet, which are beneficial to sustain TEE in the longer-term.

The present study observed that appetite profile was differently influenced by the dietary interventions in the short-term, with small increases in fullness and satiety ratings in the HPLC diet group, and small changes in opposite direction in the HCLP diet group. Habituation appeared over the longer-term. A previous study showed that the ad libitum consumption of a relatively high-protein diet induced acute increases in fullness and hunger ratings, subsequently resulting in a decreased energy intake (6). In the longer-term, fullness and hunger ratings returned to the levels of the initial diet. The sustained decrease in energy intake automatically resulted in a decreased protein intake. The initial changes in appetite as observed in our study are in line with this mechanism of protein-induced satiety. However, when translation into changes in energy intake is not possible, such as in situations where subjects have to maintain their body weight, appetite appears to show habituation. Subjects in both diet groups may have had difficulties to consume the required amounts of food during the first week of consuming the HPLC or HCLP-diets. The findings that subjects were able to keep protein intake low or high suggest that these intakes fall within the range in which humans are capable to respond and adapt for a period of at least 12 weeks.

Sustained higher fasting $\beta$-hydroxybutyrate concentrations in the HPLC than in the HCLP diet group confirmed a metabolic response to the dietary treatment. However, $\beta$-hydroxybutyrate concentrations in the HPLC diet group do not 
represent a hyperketonic state, such as was previously observed following ketogenic lower-carbohydrate diets $(49,50)$. This observation is in line with the absence of increases in fasting insulin concentrations or fat oxidation, that indicate carbohydrate intake being high enough to prevent strong ketogenesis. Nevertheless, considering the similarities in responses observed in this study, the suggested contribution of ketogenesis on appetite suppression and energy expenditure might not be neglected (25,51-53). Only a trend for lower fasting glucose concentrations at wk 12 compared with wk 1 was observed in the HPLCdiet group. In line with this observation, a previous study did not observe differences in glucose concentrations between high-protein and normal-protein diets during weight maintenance after body weight loss (54).

The strength of the present study was the longer-term intervention using diets with large contrasts in relative protein content, whereby body weight was controlled. This design enabled to predict whether relatively high-protein diets would be a concept for prevention of body weight gain. We are aware that protein intake from diets containing $5 \mathrm{En} \%$ from protein would be too low to sustain longterm health, which makes it difficult to assess the effects of these diets over a period longer than 12 weeks. Furthermore, it remains to be determined whether diets containing protein in the order of $30 \mathrm{En} \%$ are suitable to be consumed in energy balance in the longer-term. Summarizing, if energy intake is predetermined, coping with an initial higher fullness on a high-protein diet by lowering energy intake is not possible. Then, the effects of HPLC vs. HCLP diets on fullness are transient, indicating that habituation appears over the longer-term. However, maintenance of TEE via SMR and DIT on the HPLC vs. the HCLP diets was sustained after 12 weeks, and may therefore be sufficient to prevent a positive energy balance in the longer-term.

In conclusion, maintenance of energy expenditure on HPLC vs. HCLP diets at a constant body weight may prevent development of a positive energy balance.

\section{ACKNOWLEDGEMENTS}

We thank our subjects for their participation in the study. Nitrogen analyses were performed by Hasibe Aydeniz. 


\section{REFERENCES}

1. Westerterp-Plantenga MS, Lemmens SG, Westerterp KR. Dietary protein - its role in satiety, energetics, weight loss and health. British Journal of Nutrition 2012;108:S105-S12.

2. Acheson KJ. Diets for body weight control and health: the potential of changing the macronutrient composition. Eur J Clin Nutr 2013;67:462-6.

3. Wycherley TP, Moran L, Clifton PM, Noakes M, Brinkworth GD. Effects of energy-restricted highprotein, low-fat compared with standard-protein, low-fat diets: a meta-analysis of randomized controlled trials. Am J Clin Nutr 2012;96:1281-98.

4. Abete I, Astrup A, Martinez JA, Thorsdottir I, Zulet MA. Obesity and the metabolic syndrome: role of different dietary macronutrient distribution patterns and specific nutritional components on weight loss and maintenance. Nutr Rev 2010;68:214-31.

5. Westerterp-Plantenga MS, Luscombe-Marsh N, Lejeune MPGM, Diepvens K, Nieuwenhuizen A, Engelen MPKJ, Deutz NEP, Azzout-Marniche D, Tome D, Westerterp KR. Dietary protein, metabolism, and body-weight regulation: dose-response effects. International Journal of Obesity 2006;30:S16-S23.

6. Weigle DS, Breen PA, Matthys CC, Callahan HS, Meeuws KE, Burden VR, Purnell JQ. A high-protein diet induces sustained reductions in appetite, ad libitum caloric intake, and body weight despite compensatory changes in diurnal plasma leptin and ghrelin concentrations. Am J Clin Nutr 2005;82:41-8.

7. Soenen S, Martens EA, Hochstenbach-Waelen A, Lemmens SG, Westerterp-Plantenga MS. Normal protein intake is required for body weight loss and weight maintenance, and elevated protein intake for additional preservation of resting energy expenditure and fat free mass. J Nutr 2013;143:591-6.

8. Martens EA, Westerterp-Plantenga MS. Protein diets, body weight loss and weight maintenance. Curr Opin Clin Nutr Metab Care 2014;17:75-9.

9. Bray GA, Smith SR, de Jonge L, Xie H, Rood J, Martin CK, Most M, Brock C, Mancuso S, Redman LM. Effect of dietary protein content on weight gain, energy expenditure, and body composition during overeating: a randomized controlled trial. JAMA 2012;307:47-55.

10. Meredith CN, Frontera WR, O'Reilly KP, Evans WJ. Body composition in elderly men: effect of dietary modification during strength training. J Am Geriatr Soc 1992;40:155-62.

11. Lambert CP, Frank LL, Evans WJ. Macronutrient considerations for the sport of bodybuilding. Sports Med 2004;34:317-27.

12. Kim H, Lee $\mathrm{S}$, Choue R. Metabolic responses to high protein diet in Korean elite bodybuilders with high-intensity resistance exercise. J Int Soc Sports Nutr 2011;8:10.

13. Tipton KD, Phillips SM. Dietary protein for muscle hypertrophy. Nestle Nutr Inst Workshop Ser 2013;76:73-84.

14. Edholm OG. Energy balance in man studies carried out by the Division of Human Physiology, National Institute for Medical Research. J Hum Nutr 1977;31:413-31.

15. Summerbell CD, Douthwaite W, Whittaker V, Ells L, Hillier F, Smith S, Kelly S, Edmunds LD, Macdonald I. The association between diet and physical activity and subsequent excess weight gain and obesity assessed at 5 years of age or older: a systematic review of the epidemiological evidence. Int J Obes (Lond) 2009;33 Suppl 3:S1-92.

16. Halkjaer J, Olsen A, Overvad K, Jakobsen MU, Boeing H, Buijsse B, Palli D, Tognon G, Du H, van der $A D$, et al. Intake of total, animal and plant protein and subsequent changes in weight or waist circumference in European men and women: the Diogenes project. Int J Obes (Lond) 2011;35:1104-13.

17. FAO Statistics Division 2010. Food Balance Sheets. Food and Agriculture Organization of the United Nations. Rome, Italy. Version current March 2011. Available from http://faostat.fao.org/ (assessed 13 May 2014).

18. Halton TL, Hu FB. The effects of high protein diets on thermogenesis, satiety and weight loss: a critical review. J Am Coll Nutr 2004;23:373-85. 
19. Bendtsen LQ, Lorenzen JK, N.T. B, Rasmussen C, Astrup A. Effect of dairy proteins on appetite, energy expenditure, body weight, and composition: a review of the evidence from controlled clinical trials. Adv Nutr 2013;4:418-38.

20. Leidy HJ, Armstrong CL, Tang M, Mattes RD, Campbell WW. The influence of higher protein intake and greater eating frequency on appetite control in overweight and obese men. Obesity (Silver Spring) 2010;18:1725-32.

21. Lejeune MP, Westerterp KR, Adam TC, Luscombe-Marsh ND, Westerterp-Plantenga MS. Ghrelin and glucagon-like peptide 1 concentrations, 24-h satiety, and energy and substrate metabolism during a high-protein diet and measured in a respiration chamber. Am J Clin Nutr 2006;83:89-94.

22. Veldhorst MA, Nieuwenhuizen AG, Hochstenbach-Waelen A, Westerterp KR, Engelen MP, Brummer RJ, Deutz NE, Westerterp-Plantenga MS. Effects of high and normal soyprotein breakfasts on satiety and subsequent energy intake, including amino acid and 'satiety' hormone responses. Eur J Nutr 2009;48:92-100.

23. Veldhorst MA, Nieuwenhuizen AG, Hochstenbach-Waelen A, Westerterp KR, Engelen MP, Brummer RJ, Deutz NE, Westerterp-Plantenga MS. Comparison of the effects of a high- and normal-casein breakfast on satiety, 'satiety' hormones, plasma amino acids and subsequent energy intake. Br J Nutr 2009;101:295-303.

24. Mikkelsen PB, Toubro S, Astrup A. Effect of fat-reduced diets on 24-h energy expenditure: comparisons between animal protein, vegetable protein, and carbohydrate. Am J Clin Nutr 2000;72:1135-41.

25. Veldhorst MA, Westerterp KR, van Vught AJ, Westerterp-Plantenga MS. Presence or absence of carbohydrates and the proportion of fat in a high-protein diet affect appetite suppression but not energy expenditure in normal-weight human subjects fed in energy balance. $\mathrm{Br} J \mathrm{Nutr}$ 2010;104:1395-405.

26. Veldhorst MAB, Westerterp-Plantenga MS, Westerterp KR. Gluconeogenesis and energy expenditure after a high-protein, carbohydrate-free diet. American Journal of Clinical Nutrition 2009;90:519-26.

27. Westerterp KR, Wilson SA, Rolland V. Diet induced thermogenesis measured over $24 \mathrm{~h}$ in a respiration chamber: effect of diet composition. Int J Obes Relat Metab Disord 1999;23:287-92.

28. Baecke JA, Burema J, Frijters JE. A short questionnaire for the measurement of habitual physical activity in epidemiological studies. Am J Clin Nutr 1982;36:936-42.

29. Philippaerts RM, Matton L, Wijndaele K, Balduck AL, De Bourdeaudhuij I, Lefevre J. Validity of a physical activity computer questionnaire in 12- to 18 -year-old boys and girls. Int J Sports Med 2006;27:131-6.

30. Stunkard AJ, Messick S. The three-factor eating questionnaire to measure dietary restraint, disinhibition and hunger. J Psychosom Res 1985;29:71-83.

31. Westerterp-Plantenga MS, Rolland V, Wilson SA, Westerterp KR. Satiety related to $24 \mathrm{~h}$ dietinduced thermogenesis during high protein/carbohydrate vs high fat diets measured in a respiration chamber. Eur J Clin Nutr 1999;53:495-502.

32. Harris JA, Benedict FG. A Biometric Study of Human Basal Metabolism. Proc Natl Acad Sci U S A 1918;4:370-3.

33. Westerterp KR, Wouters L, Van Marken Lichtenbelt WD. The Maastricht protocol for the measurement of body composition and energy expenditure with labeled water. Obes Res 1995;3S1:49-57.

34. Schoffelen PF, Westerterp KR, Saris WH, Ten Hoor F. A dual-respiration chamber system with automated calibration. J Appl Physiol (1985) 1997;83:2064-72.

35. Weir JB. New methods for calculating metabolic rate with special reference to protein metabolism. Nutrition 1990;6:213-21.

36. Camps SG, Verhoef SP, Westerterp KR. Weight loss, weight maintenance, and adaptive thermogenesis. Am J Clin Nutr 2013;97:990-4.

37. Brouwer E. On simple formulae for calculating the heat expenditure and the quantities of carbohydrate and fat oxidized in metabolism of men and animals, from gaseous exchange (Oxygen intake and carbonic acid output) and urine-N. Acta Physiol Pharmacol Neerl 1957;6:795-802.

38. Soenen S, Plasqui G, Smeets AJ, Westerterp-Plantenga MS. Protein intake induced an increase in exercise stimulated fat oxidation during stable body weight. Physiol Behav 2010;101:770-4. 
39. Tang JE, Phillips SM. Maximizing muscle protein anabolism: the role of protein quality. Curr Opin Clin Nutr Metab Care 2009;12:66-71.

40. Gilbert JA, Bendsen NT, Tremblay A, Astrup A. Effect of proteins from different sources on body composition. Nutr Metab Cardiovasc Dis 2011;21 Suppl 2:B16-31.

41. van Loon LJ. Leucine as a pharmaconutrient in health and disease. Curr Opin Clin Nutr Metab Care 2012;15:71-7.

42. Phillips SM, Hartman JW, Wilkinson SB. Dietary protein to support anabolism with resistance exercise in young men. J Am Coll Nutr 2005;24:134S-9S.

43. Fuller MF, Garlick PJ. Human amino acid requirements: can the controversy be resolved? Annu Rev Nutr 1994;14:217-41.

44. Millward DJ. Identifying recommended dietary allowances for protein and amino acids: a critique of the 2007 WHO/FAO/UNU report. Br J Nutr 2012;108 Suppl 2:S3-21.

45. Munro HN. General aspects of the regulation of protein metabolism by hormones. Academic Press: New York; 1964.

46. Westerterp KR. Diet induced thermogenesis. Nutr Metab (Lond) 2004;1:5.

47. Stock MJ. Gluttony and thermogenesis revisited. Int J Obes Relat Metab Disord 1999;23:1105-17.

48. Miller DS, Mumford P, Stock MJ. Gluttony. 2. Thermogenesis in overeating man. Am J Clin Nutr 1967;20:1223-9.

49. Coleman MD, Nickols-Richardson SM. Urinary ketones reflect serum ketone concentration but do not relate to weight loss in overweight premenopausal women following a lowcarbohydrate/high-protein diet. J Am Diet Assoc 2005;105:608-11.

50. Johnston CS, Tjonn SL, Swan PD, White A, Hutchins H, Sears B. Ketogenic low-carbohydrate diets have no metabolic advantage over nonketogenic low-carbohydrate diets. Am J Clin Nutr 2006;83:1055-61.

51. Johnstone AM, Horgan GW, Murison SD, Bremner DM, Lobley GE. Effects of a high-protein ketogenic diet on hunger, appetite, and weight loss in obese men feeding ad libitum. Am J Clin Nutr 2008;87:44-55.

52. Scharrer E. Control of food intake by fatty acid oxidation and ketogenesis. Nutrition 1999;15: 704-14.

53. Laeger T, Metges CC, Kuhla B. Role of beta-hydroxybutyric acid in the central regulation of energy balance. Appetite 2010;54:450-5.

54. Soenen S, Bonomi AG, Lemmens SG, Scholte J, Thijssen MA, van Berkum F, Westerterp-Plantenga MS. Relatively high-protein or 'low-carb' energy-restricted diets for body weight loss and body weight maintenance? Physiol Behav 2012;107:374-80. 


\section{CHAPTER 8}

The potential of a high protein-low

carbohydrate diet to preserve intrahepatic triglyceride content in healthy humans

Martens EA, Gatta-Cherifi B, Gonnissen HK, Westerterp-Plantenga MS Accepted for publication: PlosOne 


\section{ABSTRACT}

\section{Background}

Protein supplementation has been shown to reduce the increases in intrahepatic triglyceride (IHTG) content induced by acute hypercaloric high-fat and high-fructose diets in humans.

\section{Objective}

To assess the effect of a 12-wk iso-energetic high protein-low carbohydrate (HPLC) diet compared with an iso-energetic high carbohydrate-low protein (HCLP) diet on IHTG content in healthy non-obese subjects, at a constant body weight.

\section{Design}

Seven men and nine women [mean \pm SD age: $24 \pm 5$ y; BMI: $22.9 \pm 2.1 \mathrm{~kg} / \mathrm{m}^{2}$ ] were randomly allocated to a HPLC [30:35:35 \% of energy (En\%) from protein/carbohydrate/fat] or a HCLP (5:60;35 En\%) diet by stratification on sex, age and BMI. Dietary guidelines were prescribed based on individual daily energy requirements. IHTG content was measured by ${ }^{1} \mathrm{H}$-magnetic resonance spectroscopy before and after the dietary intervention.

\section{Results}

IHTG content changed in different directions with the HPLC $\left(\mathrm{CH}_{2} \mathrm{H}_{2} \mathrm{O}: 0.23 \pm 0.17\right.$ to $0.20 \pm 0.10$; IHTG\%: $0.25 \pm 0.20 \%$ to $0.22 \pm 0.11 \%)$ compared with the HCLP diet $\left(\mathrm{CH}_{2} \mathrm{H}_{2} \mathrm{O}\right.$ : $0.34 \pm 0.20$ vs. $0.38 \pm 0.21$; IHTG\%: $0.38 \pm 0.22 \%$ vs. $0.43 \pm 0.24 \%$ ), which resulted in a lower IHTG content in the HPLC compared with the HCLP diet group after 12 weeks, which almost reached statistical significance $(P=0.055)$.

\section{Conclusions}

A HPLC vs. a HCLP diet has the potential to preserve vs. enlarge IHTG content in healthy nonobese subjects at a constant body weight. The study was registered on clinicaltrials.gov with Identifier: NCT01551238. 


\section{INTRODUCTION}

Energy-restricted high-protein diets are commonly applied as interventions aiming to induce body weight loss and related improvements in metabolic profile $(1,2)$. On the other hand, high carbohydrate-high fat diets may increase the susceptibility for overeating, which may result in the development of metabolic disturbances (3-5). Visceral adipose tissue (VAT) volume has been linked to the metabolic disturbances associated with obesity, such as a diminished insulin sensitivity and dyslipidemia (6). However, high ectopic lipid content, especially intrahepatic triglyceride (IHTG) content, and not VAT volume, is an independent risk factor for these metabolic disturbances (7-9). In obese subjects, increases in BMI, total adipose tissue volume, or VAT volume were only associated with increases in insulin resistance and disturbances in very-low-density lipoprotein (VLDL)-TG metabolism when IHTG content was increased simultaneously (9). Furthermore, insulin sensitivity was lower and VLDL secretion was higher in obese subjects with a high IHTG content (>5.5\% of liver volume), matched on VAT volume (8). No differences were observed between subjects with a high VAT volume $\left(>1100 \mathrm{~cm}^{3}\right)$ but similar IHTG content (8). Therefore, measuring IHTG content as a marker of metabolic function in dietary intervention studies is highly relevant.

Several human studies suggest that high protein intake may modulate IHTG content. A 4-wk uncontrolled study showed that protein supplementation was associated with a reduction in IHTG content in obese subjects (10). In two shortterm dietary intervention studies, protein supplementation reduced the increases in IHTG content induced by hypercaloric high-fat and high-fructose diets in healthy subjects $(11,12)$. However, the longer-term effects of dietary protein content on IHTG content, thereby excluding the possible effects of metabolic disturbances and changes in body weight are unknown. Therefore, in the context of prevention of metabolic disturbances, the aim of this dietary intervention study was to assess the effect of a 12-wk iso-energetic high protein-low carbohydrate (HPLC) diet compared with an iso-energetic high carbohydrate-low protein (HCLP) diet on IHTG content in healthy non-obese subjects, at a constant body weight.

\section{SUBJECTS AND METHODS}

The Medical Ethical Committee of Maastricht University approved the study, and all subjects gave written informed consent. The study was registered on clinicaltrials.gov with Identifier: NCT01551238. The protocol for this trial and supporting CONSORT checklist are available as supporting information; see Checklist S1 and protocol S1. 


\section{Study subjects}

Based on the study by Thetaz et al. (12), power analysis showed that with an $\alpha$ of 0.05 and a $\beta$ of 0.80 , at least 7 subjects per group were needed to show a difference in IHTG content between the dietary interventions of this study.

Twenty-four subjects were recruited by advertisements in local newspapers and on notice boards at the university. Data from measurements of four subjects were unreliable, and were therefore excluded from analysis. Four subjects had to be excluded from the data analysis because of non-compliance with the designated protein intake, as shown by the urinary nitrogen biomarker. The baseline characteristics of the excluded subjects did not differ from the total sample. Overall, 16 subjects ( 7 men and 9 women) were included in the final data analysis.

Subjects underwent a screening that included anthropometric measurements and the completion of questionnaires eliciting information about health, smoking behaviour, use of medications, and alcohol consumption. Subjects were aged between 19 and 31 y had a BMI between 19.0 and $25.3 \mathrm{~kg} / \mathrm{m}^{2}$. Age and BMI were equally divided between males and females. Subjects were non-smoking, not using more than moderate amounts of alcohol ( $>10$ drinks/wk), were weight stable (body weight change $<3 \mathrm{~kg}$ during the last 6 mo and had no planned weight change during the study period), and were not using medication or supplements except for oral contraceptives in women.

The validated Dutch translation of the Baecke Activity Questionnaire was used to measure habitual physical activity scores, which were converted into a standardized individual physical activity level $(13,14)$.

\section{Dietary intervention}

The study used a single-blind parallel design in which subjects were randomly allocated to the HPLC [30/35/35\% of energy (En\%) from protein/carbohydrate/fat] or the HCLP (5/60/35 En\%) diet following stratification on sex, age and BMI. Detailed dietary guidelines were prescribed based on individual daily energy requirements, calculated as the basal metabolic rate determined with the formula of Harris and Benedict (15) times the physical activity level (16). This was carried out in order to keep body weight constant. Moreover, subjects were told that they were expected to maintain their body weight and physical activity level. The dietary guidelines included a variety of recipes for breakfasts, lunches, dinners and snacks, consisting of commercially available food items and the amounts that had to be consumed to reach the intended diet compositions. The guidelines included the prescription to consume additional protein [HPLC: whey with $\alpha$-lactalbumin (Hiprotal Whey Protein Alpha, FrieslandCampina Domo EMEA, Amersfoort, The Netherlands)] or carbohydrate [HCLP: maltodextrin (Fantomalt, Nutricia, Zoetermeer, The Netherlands)] by shakes twice daily (Table 8.1). 
Table 8.1 Sample menu for the HPLC and HCLP diets

\begin{tabular}{lll}
\hline \hline & HPLC & HCLP \\
\hline Breakfast & Low-fat yoghurt & Whole-grain juice with forest fruits \\
& Breakfast cereals & Breakfast cereals \\
& Kiwi & Apple \\
Semi-skimmed milk & Orange juice \\
Lunch & Whole-wheat bread & Whole-wheat bread \\
& Margarine & Margarine \\
& Cheese spread & Apple spread \\
Snack & Chicken breast & Hazelnut paste \\
Dinner & Protein shake & Carbohydrate shake \\
& White rice & White rice \\
& French beans & French beans \\
& Chicken breast & Red cabbage with apple \\
& Walnuts & Red pepper \\
& Olive oil & Olive oil \\
Snack & Savoury sauce & Savoury sauce \\
& Protein shake & Carbohydrate shake \\
& Cereal bar & Corn crisps \\
\hline
\end{tabular}

The amounts that were prescribed to consume were based on individual daily energy requirements.

\section{Body weight and biomarker of protein intake}

At baseline and at weeks 5, 9 and 12, body weight was measured by using a digital balance in order to check whether it remained constant, and 24-h urinary nitrogen excretion was determined as biomarker of protein intake throughout the intervention period.

\section{IHTG content}

$\mathrm{MRI}$ and proton magnetic resonance spectroscopy $\left({ }^{1} \mathrm{H}-\mathrm{MRS}\right)$ measurements were performed using a 1.5-T whole-body scanner (Intera; Philips Healthcare, Best, The Netherlands). Sagittal, coronal and transversal images through the right lobe in the lower third of the liver were obtained by MRI (slice thickness $8 \mathrm{~mm}$; repetition time/echo time, 500/15 ms; matrix $180 \times 96$ ) in order to gain anatomical and positional information of the liver, ${ }^{1} \mathrm{H}$-MRS enabled to measure IHTG content by distinguishing hepatic water from a spectrum of IHTG. Fatty acid chains that represent different proton moiety were separated by the relative magnitude of resonance (17). A $20 \times 20 \times 20 \mathrm{~mm}$ volume of interest was positioned, avoiding the lateral margin of the liver parenchyma, major blood vessels, and intrahepatic bile ducts. The position of the volume of interest was the same at the baseline measurement and at the measurement after the intervention. Following shimming (10 × $10 \times 10 \mathrm{~cm}$ volume), eight spectra were acquired using a Q-body coil (18). Point-resolved spectroscopy sequence (PRESS) was used for spatial localization and signal acquisition using a protocol set up by Schrauwen-Hinderling et al. (repetition time/echo time, 4000/33 ms; number of signals averaged fat/water, 64/16) (19). 
Water signal was suppressed using $150 \mathrm{~Hz}$ frequency-selective prepulses. The unsuppressed water signal was measured in the same volume of interest under the same shimming conditions, and was used as a reference signal (19). Spectra were fitted using the Java-based magnetic resonance user interface (jMRUI) package fitted in the domain using a non-linear least-squares algorithm (AMARES) (19-21). Areas of resonance from protons of methylene $\left[-\left(\mathrm{CH}_{2}\right)_{\mathrm{n}^{-}}\right]$and methyl $\left(\mathrm{CH}_{3}\right)$ in the fatty acid chains, relative to the area of protons of $\mathrm{H}_{2} \mathrm{O}$, were used as a measure for the IHTG content. A more extensive description of the applied post processing procedure has been published previously $(18,19,21-23)$.

\section{Statistical analysis}

All statistical analyses were performed by using SPSS version 20 for Macintosh OS X (SPSS Inc.). Differences in subject characteristics and anthropometrics between the diet groups were assessed using Factorial ANOVA. Mann-Whitney tests were used to test for differences in IHTG content between the diet groups.

Factorial ANOVAs with repeated measures were used to test whether nitrogen excretion, body weight, and BMI changed over time within the diet groups, and to test whether these effects differed between the diet groups. Data on IHTG content were log transformed before these statistical analyses were performed. Differences were regarded statistically significant if $P<0.05$. Data are presented as mean \pm SD.

\section{RESULTS}

\section{Subject characteristics}

Subject characteristics did not differ between the diet groups at baseline (Table 8.2). No adverse events were reported.

\section{Body weight and biomarker of protein intake}

The condition of stable body weight was met in both arms. Baseline nitrogen excretion did not differ significantly between the HPLC (12.2 $\pm 3.6 \mathrm{~g} / \mathrm{d})$ and HCLP $(11.4 \pm 3.4 \mathrm{~g} / \mathrm{d})$ diets. Nitrogen excretion increased significantly in the HPLC $(23.3 \pm 4.4 \mathrm{~g} / \mathrm{d}, P<0.05)$, and decreased in the $\operatorname{HCLP}(6.5 \pm 1.3 \mathrm{~g} / \mathrm{d}, P=0.001)$ diet group compared with baseline. Significant differences in protein intake between the diet groups were confirmed in that nitrogen excretion differed significantly between the diet groups throughout the intervention period $(P=0.001)$. 
Table 8.2 Subject characteristics, anthropometrics and IHTG content in the HPLC and HCLP diet groups at baseline and after 12 weeks.

\begin{tabular}{lcccc}
\hline \hline & \multicolumn{2}{c}{ Baseline } & \multicolumn{2}{c}{ After 12 weeks } \\
\cline { 2 - 5 } & $\mathrm{HPLC}$ & $\mathrm{HCLP}$ & $\mathrm{HPLC}$ & \\
\hline No. of subjects (M/F) & $7(4 / 3)$ & $9(3 / 6)$ & \\
Age (y) & $23 \pm 5$ & $25 \pm 5$ & \\
Baecke total score & $9.4 \pm 1.0$ & $8.9 \pm 1.1$ & \\
Height (cm) & $173 \pm 8$ & $170 \pm 9$ & & \\
BW (kg) & $67.6 \pm 6.6$ & $64.5 \pm 8.2$ & $67.8 \pm 6.2$ & $64.3 \pm 7.5$ \\
BMI (kg/m $\left.{ }^{2}\right)$ & $22.6 \pm 2.0$ & $22.3 \pm 2.1$ & $22.7 \pm 2.3$ & $22.2 \pm 2.0$ \\
& & & & \\
IHTG content & & & & \\
$\mathrm{CH} \mathrm{H}_{2} \mathrm{O}$ & $0.23 \pm 0.17$ & $0.34 \pm 0.20$ & $0.20 \pm 0.10^{*}$ & $0.38 \pm 0.21^{*}$ \\
IHTG (\%) & $0.25 \pm 0.20$ & $0.38 \pm 0.22$ & $0.22 \pm 0.11^{*}$ & $0.43 \pm 0.24^{*}$ \\
\hline
\end{tabular}

Values represent numbers or means \pm SD. * Trend $(P=0.055)$ for factorial ANOVA with repeated measures between diet groups. BW, body weight; HCLP, high-carbohydrate low-protein; HPLC, highprotein low-carbohydrate; IHTG, intrahepatic triglyceride.

\section{IHTG content}

IHTG content decreased with the HPLC $\left(\mathrm{CH}_{2} \mathrm{H}_{2} \mathrm{O}: 0.23 \pm 0.17\right.$ to $0.20 \pm 0.10 ;$ IHTG\%: $0.25 \pm 0.20 \%$ to $0.22 \pm 0.11 \%)$ and increased with the HCLP diet $\left(\mathrm{CH}_{2} \mathrm{H}_{2} \mathrm{O}\right.$ : $0.34 \pm 0.20$ vs. $0.38 \pm 0.21$; IHTG\%: $0.38 \pm 0.22 \%$ vs. $0.43 \pm 0.24 \%$ ), although not reaching statistical significance (Table 8.2). These changes of IHTG content in different directions resulted in a lower IHTG content in the HPLC compared with the HCLP diet group after 12 weeks, which almost reached statistical significance $(P=0.055)$.

\section{DISCUSSION}

Protein supplementation has been shown to reduce the increases in IHTG content induced by acute hypercaloric high-fat and high-fructose diets in humans. In the context of prevention of metabolic disturbances, we assessed the longer-term effects of iso-energetic diets with large contrasts in relative protein content on IHTG content in healthy non-obese subjects, thereby excluding the possible effects of changes in body weight. The present study showed that IHTG content changed in different directions with the HPLC compared with the HCLP diet, which resulted in a lower IHTG content in the HPLC compared with the HCLP diet group after 12 weeks, which almost reached statistical significance. The observation that the condition of stable body weight was met in both diet groups confirmed that this observation was not affected by changes in body weight. The successful implementation of the dietary intervention in each diet group was confirmed by urinary nitrogen concentrations. 
A proposed mechanism for the modulation of IHTG content by a high protein intake is the stimulation of hepatic lipid oxidation due to the high energetic demand for amino acid catabolism and ketogenesis $(24,25)$. Hepatic lipid oxidation may also be stimulated by an increased bile acid production in response to high protein intake, a process that may also inhibit lipogenesis (26). Furthermore, protein-induced glucagon secretion inhibits de novo lipogenesis and stimulates hepatic ketogenesis $(27,28)$.

On the other hand, previous studies showed that hyper- and eucaloric highcarbohydrate diets stimulated the synthesis of fatty acids from dietary glucose via de novo lipogenesis (29-32). The carbohydrate-induced de novo lipogenesis correlated with plasma TG concentrations $(30,31)$. Increased IHTG deposition was shown to be the result of hepatic TG-synthesis exceeding the rate of its secretion into VLDL $(29,30)$. The relationship between high carbohydrate intake and increased VLDL-TG concentrations, possibly caused by stimulation of VLDL-TG production and inhibition of VLDL-TG clearance (33), may result in increases in hepatic TG concentrations, and subsequently in IHTG content (31). Protein supplementation has been observed to blunt the increase in IHTG content induced by short-term hypercaloric high-fructose intake in healthy subjects (12). Therefore, it is likely that the observed trend for a difference in IHTG content after the consumption of the HPLC compared with the HCLP diet may be the result of combined effects involving changes in protein and carbohydrate intake.

The strength of the present study was the application of an iso-energetic macronutrient intervention for a period that was long enough to reliably measure changes in IHTG content, thereby excluding the possible effects of metabolic disturbances and changes in body weight. Our healthy, non-obese subjects had a low IHTG content at baseline, which relates to a healthy metabolic function. This may exhibit a strong resistance to metabolic changes in response to dietary interventions when stimuli such as a high-fat or a high-fructose intake are absent $(11,12)$. This indicates that high protein-low carbohydrate diets may be biologically less relevant for inducing a significant decrease in IHTG content in healthy subjects. Nevertheless, the observations of this study are relevant by suggesting that high protein-low carbohydrate diets may be beneficial for the prevention of metabolic disturbances in healthy subjects. Measurements of energy expenditure, body composition, body fat distribution including ectopic fat deposition, and metabolic function are needed to assess the translation of high-protein diets as a treatment strategy into a preventive measure. By addressing ectopic fat deposition in response to dietary interventions, this study adds to the discussion of the clinical relevance of dietary protein for the prevention of obesity. It would also be relevant to implement the measurement of IHTG content in studies assessing the effects of high-protein diets during body weight loss and weight maintenance in patients with metabolic disturbances. 
To conclude, a HPLC vs. a HCLP diet has the potential to preserve vs. enlarge IHTG content in healthy non-obese subjects at a constant body weight.

\section{ACKNOWLEDGEMENTS}

We acknowledge Prof. Dr. Joachim E. Wildberger for giving us the opportunity to perform the MRI and ${ }^{1} \mathrm{H}$-MRS measurements at the Department of Radiology. We thank Dr. Vera B. Schrauwen-Hinderling for providing us a validated protocol for the determination of IHTG content by using MRI and ${ }^{1} \mathrm{H}-\mathrm{MRS}$, and for offering assistance with the post processing procedure, and Siti N. Wulan for her help in performing part of the studies. 


\section{REFERENCES}

1. Acheson KJ. Diets for body weight control and health: the potential of changing the macronutrient composition. Eur J Clin Nutr 2013;67:462-6.

2. Wycherley TP, Moran L, Clifton PM, Noakes M, Brinkworth GD. Effects of energy-restricted highprotein, low-fat compared with standard-protein, low-fat diets: a meta-analysis of randomized controlled trials. Am J Clin Nutr 2012;96:1281-98.

3. Westerterp KR, Verboeket-van de Venne WP, Westerterp-Plantenga MS, Velthuis-te Wierik EJ, de Graaf C, Weststrate JA. Dietary fat and body fat: an intervention study. Int J Obes Relat Metab Disord 1996;20:1022-6.

4. Westerterp KR. Perception, passive overfeeding and energy metabolism. Physiol Behav 2006; 89:62-5.

5. Stubbs RJ, Mazlan N, Whybrow S. Carbohydrates, appetite and feeding behavior in humans. J Nutr 2001;131:2775S-81S.

6. Despres JP, Lemieux I. Abdominal obesity and metabolic syndrome. Nature 2006;444:881-7.

7. Lettner A, Roden M. Ectopic fat and insulin resistance. Curr Diab Rep 2008;8:185-91.

8. Fabbrini E, Magkos F, Mohammed BS, Pietka T, Abumrad NA, Patterson BW, Okunade A, Klein S. Intrahepatic fat, not visceral fat, is linked with metabolic complications of obesity. Proc Natl Acad Sci U S A 2009;106:15430-5.

9. Magkos F, Fabbrini E, Mohammed BS, Patterson BW, Klein S. Increased whole-body adiposity without a concomitant increase in liver fat is not associated with augmented metabolic dysfunction. Obesity (Silver Spring) 2010;18:1510-5.

10. Bortolotti M, Maiolo E, Corazza M, Van Dijke E, Schneiter P, Boss A, Carrel G, Giusti V, Le KA, Quo Chong DG, et al. Effects of a whey protein supplementation on intrahepatocellular lipids in obese female patients. Clin Nutr 2011;30:494-8.

11. Bortolotti M, Kreis R, Debard C, Cariou B, Faeh D, Chetiveaux M, Ith M, Vermathen P, Stefanoni N, Le KA, et al. High protein intake reduces intrahepatocellular lipid deposition in humans. Am J Clin Nutr 2009;90:1002-10.

12. Theytaz F, Noguchi Y, Egli L, Campos V, Buehler T, Hodson L, Patterson BW, Nishikata N, Kreis R, Mittendorfer $B$, et al. Effects of supplementation with essential amino acids on intrahepatic lipid concentrations during fructose overfeeding in humans. Am J Clin Nutr 2012;96:1008-16.

13. Baecke JA, Burema J, Frijters JE. A short questionnaire for the measurement of habitual physical activity in epidemiological studies. Am J Clin Nutr 1982;36:936-42.

14. Philippaerts RM, Matton L, Wijndaele K, Balduck AL, De Bourdeaudhuij I, Lefevre J. Validity of a physical activity computer questionnaire in 12- to 18-year-old boys and girls. Int J Sports Med 2006;27:131-6.

15. Harris JA, Benedict FG. A Biometric Study of Human Basal Metabolism. Proc Natl Acad Sci U S A 1918;4:370-3.

16. Westerterp KR, Wouters L, van Marken Lichtenbelt WD. The Maastricht protocol for the measurement of body composition and energy expenditure with labeled water. Obes Res 1995;3 Suppl 1:49-57.

17. Hamilton G, Yokoo T, Bydder M, Cruite I, Schroeder ME, Sirlin CB, Middleton MS. In vivo characterization of the liver fat (1)H MR spectrum. NMR Biomed 2011;24:784-90.

18. Szczepaniak LS, Nurenberg P, Leonard D, Browning JD, Reingold JS, Grundy S, Hobbs HH, Dobbins $\mathrm{RL}$. Magnetic resonance spectroscopy to measure hepatic triglyceride content: prevalence of hepatic steatosis in the general population. Am J Physiol Endocrinol Metab 2005;288:E462-8.

19. Schrauwen-Hinderling VB, van Loon LJ, Koopman R, Nicolay K, Saris WH, Kooi ME. Intramyocellular lipid content is increased after exercise in nonexercising human skeletal muscle. J Appl Physiol (1985) 2003;95:2328-32.

20. Naressi A, Couturier C, Devos JM, Janssen M, Mangeat C, de Beer R, Graveron-Demilly D. Javabased graphical user interface for the MRUI quantitation package. MAGMA 2001;12:141-52.

21. Vanhamme L, van den Boogaart A, Van Huffel S. Improved method for accurate and efficient quantification of MRS data with use of prior knowledge. J Magn Reson 1997;129:35-43. 
22. Boesch C, Slotboom J, Hoppeler H, Kreis R. In vivo determination of intra-myocellular lipids in human muscle by means of localized 1H-MR-spectroscopy. Magn Reson Med 1997;37:484-93.

23. Schick F, Eismann B, Jung WI, Bongers H, Bunse M, Lutz O. Comparison of localized proton NMR signals of skeletal muscle and fat tissue in vivo: two lipid compartments in muscle tissue. Magn Reson Med 1993;29:158-67.

24. Veldhorst MA, Westerterp-Plantenga MS, Westerterp KR. Gluconeogenesis and energy expenditure after a high-protein, carbohydrate-free diet. Am J Clin Nutr 2009;90:519-26.

25. Westerterp-Plantenga MS, Lemmens SG, Westerterp KR. Dietary protein - its role in satiety, energetics, weight loss and health. Br J Nutr 2012;108 Suppl 2:S105-12.

26. Watanabe M, Houten SM, Wang L, Moschetta A, Mangelsdorf DJ, Heyman RA, Moore DD, Auwerx J. Bile acids lower triglyceride levels via a pathway involving FXR, SHP, and SREBP-1c. J Clin Invest 2004;113:1408-18.

27. Torres N, Tovar AR. The role of dietary protein on lipotoxicity. Nutr Rev 2007;65:S64-8.

28. Gannon MC, Nuttall JA, Damberg G, Gupta V, Nuttall FQ. Effect of protein ingestion on the glucose appearance rate in people with type 2 diabetes. J Clin Endocrinol Metab 2001;86:1040-7.

29. Agius L. High-carbohydrate diets induce hepatic insulin resistance to protect the liver from substrate overload. Biochem Pharmacol 2013;85:306-12.

30. Hudgins LC, Hellerstein MK, Seidman CE, Neese RA, Tremaroli JD, Hirsch J. Relationship between carbohydrate-induced hypertriglyceridemia and fatty acid synthesis in lean and obese subjects. J Lipid Res 2000;41:595-604.

31. Schwarz JM, Neese RA, Turner S, Dare D, Hellerstein MK. Short-term alterations in carbohydrate energy intake in humans. Striking effects on hepatic glucose production, de novo lipogenesis, lipolysis, and whole-body fuel selection. J Clin Invest 1995;96:2735-43.

32. Hudgins LC, Hellerstein M, Seidman C, Neese R, Diakun J, Hirsch J. Human fatty acid synthesis is stimulated by a eucaloric low fat, high carbohydrate diet. J Clin Invest 1996;97:2081-91.

33. Parks EJ, Hellerstein MK. Carbohydrate-induced hypertriacylglycerolemia: historical perspective and review of biological mechanisms. Am J Clin Nutr 2000;71:412-33. 


\section{CHAPTER 9}

Prolonged adaptation to a low-protein diet does not lead to a more negative whole-body protein balance when compared with a high-protein diet

Hursel R, Martens EA, Gonnissen HK, Hamer HM, Senden JM, van Loon LC, Westerterp-Plantenga MS 


\section{ABSTRACT}

\section{Background}

Based on controlled 36-h experiments a higher dietary protein intake causes a positive protein balance and a negative fat balance. A positive net protein balance may support fatfree mass accrual. However, few data are available on the impact of more prolonged changes in habitual protein intake on whole-body protein metabolism and basal muscle protein synthesis rates.

\section{Objective}

To assess changes in whole-body protein turnover and basal muscle protein synthesis rates following 12 weeks of adaptation to a high vs. a low dietary protein intake.

\section{Methods}

A 12-wk randomized parallel study was performed in 7 men and 8 women (BMI: $22.8 \pm 2.3 \mathrm{~kg} / \mathrm{m}^{2}$, age: $24.3 \pm 4.9 \mathrm{y}$ ) who followed either a high-protein (HP: $2.4 \mathrm{~g} / \mathrm{kg}$ body weight/d) or a low-protein (LP: $0.4 \mathrm{~g} / \mathrm{kg}$ body weight/d) energy-balanced diet (30/35/35\% or $5 / 60 / 35 \%$ energy from protein/carbohydrate/fat). Immediately after the diet, continuous infusions with L-[ring- ${ }^{2} \mathrm{H}_{5}$ ]phenylalanine and L-[ring- ${ }^{2} \mathrm{H}_{2}$ ]tyrosine were applied, while blood samples and muscle biopsies were collected to assess fasting whole-body protein turnover and basal muscle protein synthesis rates (FSR) in vivo in humans. Compliance to the diets was checked by urinary nitrogen excretion.

\section{Results}

After 12 weeks of intervention, whole-body protein balance was more negative in the HP group when compared with the LP group $(-4.1 \pm 0.5$ vs. $-2.7 \pm 0.6 \mu \mathrm{mol}$ phenylalanine $/ \mathrm{kg}$ body weight/h; $P<0.001)$. Whole-body protein breakdown $(43.0 \pm 4.4$ vs. $37.8 \pm 3.8 \mu \mathrm{mol}$ phenylalanine $/ \mathrm{kg}$ body weight $/ \mathrm{h} ; P<0.001)$, synthesis $(38.9 \pm 4.2$ vs. $35.1 \pm 3.6 \mu \mathrm{mol}$ phenylalanine $/ \mathrm{kg}$ body weight $/ \mathrm{h} ; P<0.01)$ and phenylalanine hydroxylation rates $(4.1 \pm 0.6$ vs. $2.7 \pm 0.6 \mu \mathrm{mol}$ phenylalanine $/ \mathrm{kg}$ body weight $/ \mathrm{h} ; P<0.001$ ) were significantly higher in the HP group vs. the LP group. Basal FSR was maintained on a LP vs. HP diet $(0.042 \pm 0.01$ vs. $0.045 \pm 0.01 \% / \mathrm{h} ; P=0.620$ ).

\section{Conclusion}

Adaptation to a low-protein intake $(0.4 \mathrm{~g} / \mathrm{kg}$ body weight/d) does not result in a more negative whole-body protein balance nor reduce basal muscle protein synthesis rates when compared to a high-protein intake. ICTRP, registration number NCT01551238. 


\section{INTRODUCTION}

High-protein diets have attracted interest for many years because of their ability to preserve fat-free mass (FFM) during negative energy balance $(1,2)$. While being in a neutral or positive energy balance, a temporary increase in dietary protein ingestion for 3 months can lead to an increase in $\operatorname{FFM}(3,4)$, especially when combined with regular exercise (5). Therefore, a temporary increase in dietary protein intake may act as a preventive measure to remain weight stable (6). However, the impact of prolonged adaptation to a low or high protein intake on whole-body protein balance or muscle protein synthesis (MPS) has not been assessed. An increase in protein turnover due to increased protein consumption may be responsible for the preservation or increase of FFM irrespective of energy balance.

Several studies (2) have shown that ingestion of dietary protein may stimulate net muscle protein accretion. The postprandial rise in circulating essential amino acids (EAA), and leucine in particular, has been identified as being the key factor stimulating the postprandial rise in MPS rate $(8,9)$. In contrast to prolonged consumption of a high dietary protein diet, it is thought that relatively low protein consumption may lead to a reduction in protein turnover, due to a decrease in protein synthesis and an increase in protein breakdown. A diet providing 15 energy\% of protein, or an absolute amount of $0.8 \mathrm{~g} / \mathrm{kg}$ body weight $/ \mathrm{d}$ is recommended to maintain proper protein balance $(13,14)$. Prolonged underconsumption of dietary protein could theoretically lead to a decrease in muscle mass. Nevertheless, despite a large amount of short-term studies investigating the impact of dietary protein on whole-body protein turnover and MPS, hardly any trials have examined this matter over an extended period of time, neither did any trial compare high-protein diets with the effect of low-protein diets over an extended period of time. In the present study we assess the impact of a highprotein diet vs. a low-protein diet on post-absorptive whole-body protein balance and fasting MPS rates in vivo in humans.

\section{SUBJECTS AND METHODS}

\section{Subjects}

In the main study, Martens et al. ( $n=37$ ) (unpublished observations) studied the impact of a high-protein diet compared with a low-protein diet on satiety and energy expenditure. In a subgroup of subjects $(n=20)$ we determined postabsorptive whole-body protein metabolism and basal muscle protein synthesis rates to assess possible changes following 12 weeks of adaptation to a high vs. low dietary protein intake. After drop-out of 5 subjects $(2$ subjects due to agenda 
problems, one subject we were not able to place the catheters and 2 subjects withdrew from the study without giving any reason), fifteen subjects, (7 men and 8 women), aged 19 to 31 years; BMI between 19 and $26 \mathrm{~kg} / \mathrm{m}^{2}$ ) participated in the current study. The power calculation, with a 2-sided significance level of 0.05 and power of 0.8 , was based on previous research on whole-body protein metabolism (15). In the reference study, a crossover design with ten healthy subjects was performed and resulted in significant effects of dietary protein consumption on whole-body protein balance.

Subjects were recruited via advertisements in local newspapers and on notice boards at the university. Subjects underwent a screening and all were in good health, non-smokers, not using medication (except for oral contraception) and moderate alcohol users ( $<10$ drinks per week). None of them had a food allergy, gained or lost more than $3 \mathrm{~kg}$ in six months prior to the study, or were cognitive dietary restrained (F1>9) as assessed by a validated Dutch translation of the Three Factor Eating Questionnaire (16). The validated Dutch translation of the Baecke Activity Questionnaire was used to measure habitual physical activity (17). This study was conducted according to guidelines laid down in the Declaration of Helsinki and the Medical Ethical Committee of Maastricht University Medical Centre approved all procedures involving human subjects. All subjects provided written informed consent. The main study was registered at the International Clinical Trials Registry Platform as NCT01551238.

\section{Study design}

The study had a randomized, single-blinded, parallel design and consisted of a longterm (12 weeks) dietary intervention. Subjects were randomly divided in two groups that received either a high protein (HP, 30/35/35\% of energy from protein/carbohydrate/fat) or a low protein energy-balanced diet (LP, 5/60/35\% of energy from protein/carbohydrate/fat).

In order to maintain their diet at home, all subjects received a booklet containing individual guidelines with permitted and non-permitted foods and their corresponding portions, as well as three example menus. The example menus consisted of commercially available food products and were tailored to the energy requirements of each subject based on basal metabolic rate calculated with the Harris and Benedict equation (18) and multiplied with a physical activity level of 1.7 estimated by means of a computer simulation program (19). Subjects on the HP diet (30\% of energy from protein) had to drink two protein shakes each day during 12 weeks. The supplemental protein was whey protein with $\alpha$-lactalbumin (Hiprotal Whey Protein Alpha and Domo; FrieslandCampina). Subjects on the LP diet ( $60 \%$ of energy from carbohydrate) had to drink two carbohydrate shakes each day during 12 weeks. The supplemental carbohydrate was maltodextrin (Fantomalt, Nestle). The fat content between conditions was maintained at a constant proportion ( $35 \%$ of energy from fat). Subjects were instructed to keep 
their weight stable. Subject characteristics reported in Table 9.1 were determined as described by Martens et al. (unpublished observations).

Table $9.1 \quad$ Subjects' characteristics ${ }^{1}$

\begin{tabular}{|c|c|c|c|c|}
\hline & HP & LP & Total & $P$-value \\
\hline No. of subjects (M/F) & $9(4 / 5)$ & $6(3 / 3)$ & $15(7 / 8)$ & \\
\hline Age (y) & $23.9 \pm 4.2$ & $25.0 \pm 6.2$ & $24.3 \pm 4.9$ & 0.686 \\
\hline Height (m) & $1.70 \pm 0.08$ & $1.70 \pm 0.09$ & $1.70 \pm 0.09$ & 0.899 \\
\hline Weight (kg) & $62.8 \pm 6.1$ & $67.3 \pm 8.6$ & $65.1 \pm 7.1$ & 0.312 \\
\hline$\Delta$ Weight $(\mathrm{kg})$ & $+0.71 \pm 0.8$ & $+0.06 \pm 1.2$ & $+0.45 \pm 0.98$ & 0.216 \\
\hline BMI $\left(\mathrm{kg} / \mathrm{m}^{2}\right)$ & $22.1 \pm 2.4$ & $23.3 \pm 2.2$ & $22.6 \pm 2.3$ & 0.373 \\
\hline$\Delta \mathrm{BMI}\left(\mathrm{kg} / \mathrm{m}^{2}\right)$ & $+0.26 \pm 0.30$ & $+0.04 \pm 0.39$ & $+0.17 \pm 0.34$ & 0.903 \\
\hline FM\% & $24.2 \pm 7.3$ & $22.7 \pm 7.8$ & $23.6 \pm 7.3$ & 0.339 \\
\hline$\Delta \mathrm{FM}(\%)$ & $+0.04 \pm 1.31$ & $+0.32 \pm 0.97$ & $+0.15 \pm 1.16$ & 0.672 \\
\hline FFM\% & $75.8 \pm 7.3$ & $77.4 \pm 7.8$ & $76.5 \pm 7.3$ & 0.709 \\
\hline$\Delta \mathrm{FFM}(\%)$ & $-0.04 \pm 1.31$ & $-0.32 \pm 0.97$ & $-0.15 \pm 1.16$ & 0.672 \\
\hline PAL & $1.82 \pm 0.14$ & $1.79 \pm 0.15$ & $1.81 \pm 0.14$ & 0.677 \\
\hline
\end{tabular}

${ }^{1} \Delta$ changes over 12 wk. FM, fat mass; FFM, fat-free mass; PAL, physical activity level. Values are expressed as mean \pm SD. Data were analyzed with one-way ANOVA. Table adapted and modified from Martens et al. (unpublished observations).

\section{Biomarker of protein intake}

Nitrogen excretion was used as biomarker for protein intake. Subjects collected their 24-h urine at five different time points during the 12-wk period. Collection started after the first voiding in the morning at 8:00h and lasted until the next day at $8: 00 \mathrm{~h}$ including the first voiding. The total volume of the $24-\mathrm{h}$ urine was recorded. Urine was collected in $2-I$ urine bottles with $10 \mathrm{ml}$ of diluted hydrochloric acid ( $4 \mathrm{mmol} / \mathrm{l}$ ) added to prevent nitrogen loss through evaporation. Urine was gently mixed, and samples were taken and stored at $-20^{\circ} \mathrm{C}$ until analysis. Nitrogen concentrations were measured with a nitrogen analyzer (CHO-O-Rapid; Hereaus).

\section{Test day}

The experiment started at 8:00h, when overnight-fasted subjects arrived at the laboratory by car or public transportation. A polytetrafluoroethylene catheter was inserted into an antecubital vein for stable isotope infusion. A second polytetrafluoroethylene catheter was inserted in a heated dorsal hand vein of the contralateral arm and placed in a hot box $\left(60^{\circ} \mathrm{C}\right)$ for arterialized blood sampling (20). After basal blood collection ( $t=0 \mathrm{~min}$ ), plasma phenylalanine (Phe) and tyrosine (Tyr) pools were primed with a single intravenous dose of L-[ring- $\left.{ }^{2} \mathrm{H}_{5}\right]$ Phe ( $2 \mu \mathrm{mol} / \mathrm{kg}$ body weight) and L-[ring- $\left.{ }^{2} \mathrm{H}_{2}\right] \mathrm{Tyr}(0.615 \mu \mathrm{mol} / \mathrm{kg}$ body weight), after which a continuous L-[ring- ${ }^{2} \mathrm{H}_{5}$ ]Phe and L-[ring- $\left.{ }^{2} \mathrm{H}_{2}\right]$ Tyr infusion was started $(0.050 \pm$ $0.0005, \quad 0.015 \pm 0.0001$ and $0.100 \pm 0.0009 \mu \mathrm{mol} / \mathrm{kg}$ body weight $/ \mathrm{min}$, respectively). After resting in a supine position for $120 \mathrm{~min}$, a second arterialized 
blood sample was drawn, and a muscle biopsy was collected from the vastus lateralis muscle $(t=120 \mathrm{~min})$. Additional arterialized blood samples $(8 \mathrm{ml})$ were collected at $t=180,240$, and 300 min with a second muscle biopsy taken, from the contralateral leg, at $t=300 \mathrm{~min}$, which marked the end of the fasting basal period as well as the experiment. Blood samples were collected in tubes containing EDTA and centrifuged at $1000 \times \mathrm{g}$ for $10 \mathrm{~min}$ at $4^{\circ} \mathrm{C}$. Aliquots of plasma were frozen in liquid nitrogen and stored at $-80^{\circ} \mathrm{C}$. Muscle biopsies were obtained from the middle region of the vastus lateralis, $15 \mathrm{~cm}$ above the patella and $\sim 3 \mathrm{~cm}$ below entry through the fascia, by using the percutaneous needle biopsy technique (1). Muscle samples were dissected carefully and freed from any visible nonmuscle material. Muscle samples were immediately frozen in liquid nitrogen and stored at $-80^{\circ} \mathrm{C}$ until additional analysis.

\section{Plasma analysis}

Plasma glucose (Uni Kit III, 07367204; Roche) concentrations were analyzed with a COBAS-FARA semiautomatic analyzer (Roche). Insulin was analyzed by using a radioimmunoassay (Insulin RIA kit; LINCO Research $\mathrm{Inc}$ ). Plasma (100 ml) for amino acid analyses was deproteinized on ice with $10 \mathrm{mg}$ dry 5-sulphosalicylic acid, mixed, and the clear supernatant fluid was collected after centrifugation. Plasma amino acid concentrations were determined by using HPLC after precolumn derivatization with o-phthaldialdehyde (2). For plasma ring- ${ }^{2} \mathrm{H}$-enrichment measurements, plasma Phe and Tyr were derivatized to their $t$-butyldimethylsilyl derivatives and analyzed by using gas chromatography-mass spectrometry (GC-MS) (Agilent 6890N GC/5973N MSD; Agilent) by using selected ion monitoring of masses 336 and 341 for unlabeled and labeled (ring- ${ }^{2} \mathrm{H}_{5}$ ) Phe, respectively; and masses 466, 468, and 470 for unlabeled and labeled (ring ${ }^{2} \mathrm{H}_{2}$ and ring- ${ }^{2} \mathrm{H}_{4}$ ) Tyr, respectively (3). Thereafter, ratios of labeled:unlabeled derivatives were analyzed by using gas chromatography-combustion isotope ratio mass spectrometry (FinniganMAT 252; ThermoFisher Scientific). Standard regression curves were applied in all isotopic enrichment analyses to assess the linearity of the mass spectrometer and to control for the loss of tracer.

\section{Muscle analysis}

For the measurement of L-[ring- ${ }^{2} \mathrm{H}_{5}$ ]Phe enrichment in the muscle tissue-free amino acid pool and mixed muscle protein, $55 \mathrm{mg}$ wet muscle was freeze-dried. Collagen, blood, and other nonmuscle fiber material were removed from muscle fibers under a light microscope. The isolated muscle fiber mass (10-15 mg) was weighed, and 8 volumes ( $8 x$ dry weight of isolated muscle fibers $x$ wet:dry ratio) of ice-cold $2 \%$ perchloric acid were added. The tissue was homogenized and centrifuged. The supernatant fluid was collected and processed in the same 
manner as plasma samples, such that tissue-free L-[ring- ${ }^{2} \mathrm{H}_{5}$ ]Phe enrichments could be measured by using their $t$-butyldimethylsilyl derivatives on aGC-MS.

The protein pellet was washed with 3 additional $1.5-\mathrm{ml}$ washes of $2 \%$ perchloric acid, dried, and hydrolyzed in $6 \mathrm{~mol} / \mathrm{l} \mathrm{HCl}$ at $120^{\circ} \mathrm{C}$ for $15-18 \mathrm{~h}$. The hydrolyzed protein fraction was dried under a nitrogen stream while heated to $120^{\circ} \mathrm{C}$, and a $50 \%$ acetic acid solution was added, and the hydrolyzed protein was passed over a Dowex exchange resin (AG 50W-X8, 100-200 mesh hydrogen form; Biorad) by using $2 \mathrm{~mol} / \mathrm{I} \mathrm{NH}_{4} \mathrm{OH}$. The eluate was collected, and L-[ring- $\left.{ }^{2} \mathrm{H}_{5}\right]$ Phe was derivatized to $\mathrm{N}$-methyl-N-tert-butyldimethylsilyltrifluoroacetamidephenylethyl-amine (4). Thereafter, ratios of labeled:unlabeled derivatives were determined by using GC-MS. Standard regression curves were applied to assess the linearity of the mass spectrometer and to control for the loss of tracer.

\section{Calculations}

The intravenous infusion of L-[ring- ${ }^{2} \mathrm{H}_{5}$ ]Phe and L-[ring- $\left.{ }^{2} \mathrm{H}_{2}\right] \mathrm{Tyr}$, and arterialized blood sampling were used to assess whole-body protein metabolism in steady state conditions. The total Phe rate of appearance ( $R$ a) was calculated by using modified Steele's equations $(24,25)$. These variables were calculated as follows:

(1) $T$ Total $R_{\mathrm{a}}=\left(F-\left(\mathrm{pV} \times C(\mathrm{t}) \times \mathrm{dE} \mathrm{E}_{\mathrm{iv}} / \mathrm{dt}\right)\right) / \mathrm{E}_{\mathrm{iv}}(\mathrm{t})=$ protein breakdown

where $F$ is the intravenous tracer infusion rate ( $\mu \mathrm{mol} / \mathrm{kg}$ body weight $/ \mathrm{min}$ ), $\mathrm{pV}(0.125)$ is the distribution volume for Phe (6). $C(t)$ is the mean plasma Phe concentration between two consecutive time points. $\mathrm{d} E_{\mathrm{iv}} / \mathrm{dt}$ represents the timedependent variations of plasma Phe enrichment derived from the intravenous tracer, and $E_{\mathrm{iv}}(t)$ is the mean plasma Phe enrichment from the intravenous tracer between 2 consecutive time points. Total $R_{\mathrm{a}}$ represents the plasma entry of Phe derived from whole-body protein breakdown. The total rate of disappearance of Phe (total $R_{\mathrm{d}}$ ) equals the Phe-to-Tyr conversion rate (first step in Phe oxidation) and utilization for protein synthesis. These variables were calculated as follows:

(2) $T$ Total $R_{\mathrm{d}}=$ total $R_{\mathrm{a}}-(\mathrm{pV} \times \mathrm{dC} / \mathrm{dt})$

(3) $\mathrm{PHE}$ to TYR conversion $=\operatorname{Tyr} R_{\mathrm{a}} \times\left(\left(E_{\mathrm{t}}(\mathrm{t})\right) /\left(E_{\mathrm{p}}(\mathrm{t})\right)\right) \times\left(\mathrm{Phe} R_{\mathrm{d}} /\left(F \mathrm{p}+\mathrm{Phe} R_{\mathrm{d}}\right)\right)$

(4) Protein synthesis = total $R_{\mathrm{d}}-$ PHE to TYR conversion

(5) PHE net balance $=$ protein synthesis - Total $R_{\mathrm{a}}$ 
where Phe $R_{\mathrm{d}}$ and Tyr $R_{\mathrm{a}}$ are the flux rates for Phe and Tyr, respectively; $E_{\mathrm{t}}(t)$ and $E_{\mathrm{p}}(t)$ are the mean plasma enrichments of L-[ring- $\left.{ }^{2} \mathrm{H}_{2}\right] \mathrm{Tyr}$ and $\mathrm{L}-\left[\right.$ ring- $\left.{ }^{2} \mathrm{H}_{5}\right] \mathrm{Phe}$, respectively; and $F_{\mathrm{p}}$ is the infusion rate of the Phe tracer. The fractional synthetic rate (FSR) of mixed muscle protein (in $\% / h$ ) was calculated by using the precursorproduct method (3):

(6) $\operatorname{FSR}=\left(\Delta E_{\mathrm{p}} /\left(E_{\text {precursor }} \times t\right)\right) \times 100$

where $\Delta E_{\mathrm{p}}$ is the $\Delta$ increment of muscle protein-bound L-[ring- $\left.{ }^{2} \mathrm{H}_{5}\right]$ Phe during the incorporation period. $E_{\text {precursor }}$ is the average plasma L-[ring- ${ }^{2} \mathrm{H}_{5}$ ]Phe enrichment during the time period for determination of amino acid incorporation, and $t$ indicates the time interval $(\mathrm{h})$ between biopsies.

\section{Statistical analysis}

A one-way ANOVA was used to assess differences in subject characteristics, hormone, amino acid concentrations and basal FSRs between treatments. Further, a 2-factor ANOVA with time as factor 1 and treatment as factor 2 was used to assess differences between treatments over time (time $x$ treatment interaction) for plasma Phe, Tyr, Leu concentrations and plasma enrichments, as well as wholebody protein metabolism. In case of a significant time $x$ treatment interaction, pairwise comparisons for individual time points were applied to locate differences between treatments. Finally, a 2-factor repeated measures ANOVA was used to assess differences over time and between treatments for protein intake, excretion and balance. Statistical significance was set at $P<0.05$. All calculations were performed with the SPSS 20.0 software package (SPSS Inc.). All data are expressed as means \pm SEMs.

\section{RESULTS}

\section{Plasma analyses}

Basal plasma insulin (10.9 \pm 1.8 vs. $11.0 \pm 1.7 \mathrm{mU} / \mathrm{l} ; P=0.948)$ and glucose $(4.95 \pm 0.18$ vs. $4.62 \pm 0.11 \mathrm{mmol} / \mathrm{l} ; P=0.202$ ) concentrations did not differ between the HPLC vs. HCLP group after 12 weeks.

Plasma Phe is illustrated over time in Figure 9.1A. After 12 wk on a HP vs. LP diet plasma Phe levels were not significantly different between groups $(P=0.121)$. Plasma Tyr $(P<0.01)$ and Leu $(P<0.01)$ concentrations were significantly increased after the HP diet compared with the LP diet. At wk 12, basal EAA $(P=0.199)$, basal branched-chain amino acids $(P=0.402)$ and basal total amino acids $(P=0.717)$ 
concentrations in plasma were not different between the HP vs. LP group (Table 9.2).

Figure 9.1B shows the time course of the plasma L- $\left[\right.$ ring $\left.^{2} \mathrm{H}_{5}\right]$ phenylalanine enrichment. Plasma L- $\left[\right.$ ring $\left.^{2} \mathrm{H}_{5}\right]$ phenylalanine enrichments were significantly higher in the LP group compared with the HP group $(P<0.001)$.

Table 9.2 Hormone and amino acids concentrations in plasma ${ }^{1}$

\begin{tabular}{lccc}
\hline \hline & HP & LP & $P$-value \\
\hline Glucose $(\mathrm{mmol} / \mathrm{l})$ & $4.95 \pm 0.18$ & $4.62 \pm 0.11$ & 0.948 \\
Insulin $(\mathrm{Mu} / \mathrm{l})$ & $10.86 \pm 1.81$ & $11.04 \pm 1.70$ & 0.202 \\
Phenylalanine $(\mu \mathrm{mol} / \mathrm{I})$ & $55 \pm 2$ & $52 \pm 4$ & 0.121 \\
Tyrosine $(\mu \mathrm{mol} / \mathrm{l})$ & $54 \pm 3$ & $46 \pm 3$ & $<0.01$ \\
Leucine $(\mu \mathrm{mol} / \mathrm{l})$ & $122 \pm 5$ & $105 \pm 8$ & $<0.01$ \\
Total BCAA $(\mu \mathrm{mol} / \mathrm{l})$ & $457 \pm 42$ & $374 \pm 41$ & 0.199 \\
Total EAA $(\mu \mathrm{mol} / \mathrm{l})$ & $969 \pm 75$ & $880 \pm 54$ & 0.402 \\
Total AA $(\mu \mathrm{mol} / \mathrm{l})$ & $2566 \pm 148$ & $2642 \pm 117$ & 0.717 \\
\hline
\end{tabular}

${ }^{1}$ BCAA, branched chain amino acids; EAA, essential amino acids; AA, amino acids. Values are expressed as mean \pm SEM. Data were analyzed with one-way ANOVA.
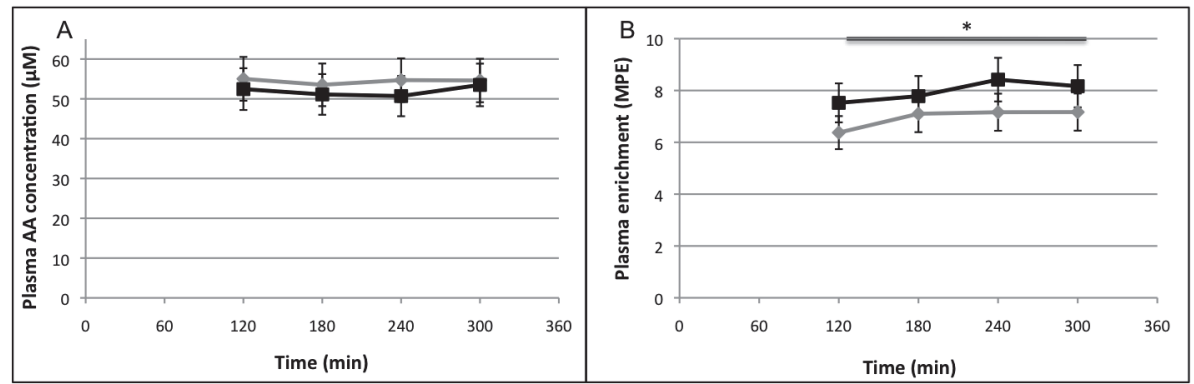

Figure 9.1 Mean ( \pm SEM) plasma Phe $(A)$ concentration $(\mu \mathrm{mol} / \mathrm{l})$ and plasma L-[ring- $\left.{ }^{2} \mathrm{H}_{5}\right] \mathrm{Phe}(\mathrm{B})$ enrichment (MPE) after 12 wk on a HP (grey) vs. LP (black) diet. Data were analyzed with a two-factor ANOVA (time $x$ treatment). *Treatment effect $P<0.001$.

\section{Whole-body protein metabolism}

Whole-body protein synthesis, breakdown, oxidation and net balance in the fasted state are expressed as the AUC in Figure 9.2. Whole-body protein synthesis, reflected by the Phe-utilization and expressed as the average of total Phe $R_{d}$ minus the conversion rate of Phe into Tyr, was significantly higher in the HP group vs. LP group (38.9 \pm 4.2 vs. $35.1 \pm 3.6 \mu \mathrm{mol}$ Phe $/ \mathrm{kg}$ body weight $/ \mathrm{h} ; P<0.01)$. Phe released into the systemic circulation from whole-body protein breakdown and expressed as the mean of Total $R_{a}$ was also larger after 12 weeks on a HP diet vs. a LP diet $(43.0 \pm 4.4$ vs. $37.8 \pm 3.8 \mu \mathrm{mol}$ Phe $/ \mathrm{kg}$ body weight $/ \mathrm{h} ; P<0.001)$. 
Phenylalanine $R_{d}$ was also increased in the HP group vs. the LP group ( $43.0 \pm 4.4$ vs. $37.8 \pm 3.8 \mu \mathrm{mol}$ Phe/kg body weight/h; $P<0.001$ ).

Whole-body protein oxidation, which was expressed as the average of the Pheto-Tyr conversion rate, was greater in the HP group vs. the LP group ( $4.1 \pm 0.6$ vs. $2.7 \pm 0.6 \mu \mathrm{mol} P h e / \mathrm{kg}$ body weight $/ \mathrm{h} ; P<0.001)$. The deduction of synthesis minus breakdown, resulting in whole-body protein balance, was more negative in the HP group compared with the LP group (-4.1 \pm 0.5 vs. $-2.7 \pm 0.6 \mu \mathrm{mol}$ Phe/kg body weight/h; $P<0.001)$.

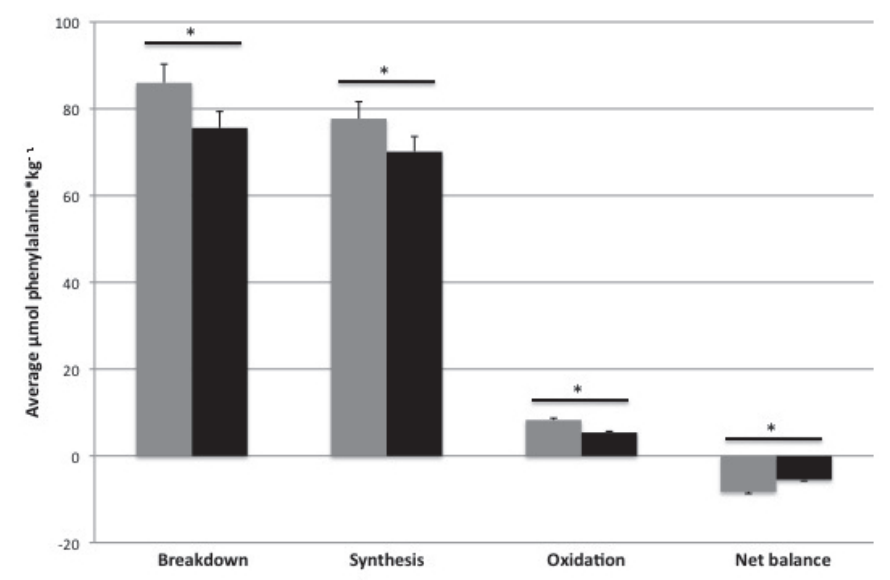

Figure 9.2 Mean ( \pm SEM) basal whole-body protein metabolism expressed as the AUC ( $\mu \mathrm{mol}$ Phe/kg body weight) after 12 wk on a HP (grey) vs. LP (black) diet. Data were analyzed with a twofactor ANOVA (time $x$ treatment). *Treatment effect $P<0.001$.

Whole-body protein metabolism differed significant between men and women with higher protein synthesis $(P<0.05)$, protein breakdown $(P<0.01)$ and protein oxidation $(P<0.001)$ rates as well as a more negative protein net balance $(P<0.001)$ in men compared with women. When expressed per kg FFM, only protein synthesis and protein breakdown rates differed between genders, with higher protein synthesis $(P<0.03)$ and protein breakdown $(P=0.05)$ rates for women. There were no significant interactions between gender and treatment for whole-body protein metabolism.

\section{Muscle tracer analysis and mixed-muscle protein synthesis rates}

The increment in muscle protein bound L-[ring- $\left.{ }^{2} \mathrm{H}_{5}\right]$ Phe enrichment between the first and the second biopsy did not differ between the HP group and the LP group (0.0094 \pm 0.0023 vs. $0.0101 \pm 0.032 \mathrm{MPE} ; P=0.615)$. 
Post-absorptive mixed MPS rates (Figure 9.3) did not differ following 12 weeks on either the HP diet or LP diet (0.042 \pm 0.01 vs. $0.045 \pm 0.01 \% / \mathrm{h} ; P=0.620)$. FSRs were significantly higher in women vs. men $(P<0.01)$, without any significant interaction for gender vs. treatment.

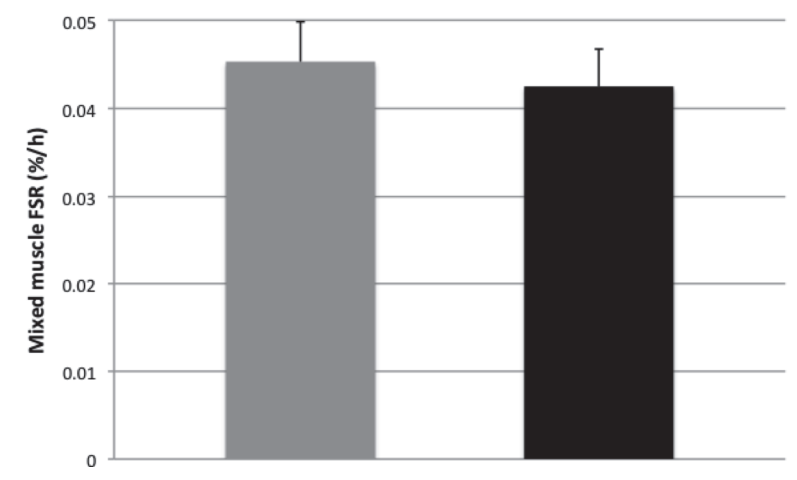

Figure 9.3 Mean ( \pm SEM) mixed muscle protein fractional synthesis rates in the basal state after 12 weeks on a HP (grey) vs. LP (black) diet. Data were analyzed with a one-way ANOVA.

\section{Protein balance}

In Figure 9.4 we present results for this subgroup, taken from Martens et al. (unpublished observations) that reflect the protein balance, based on nitrogen retention.

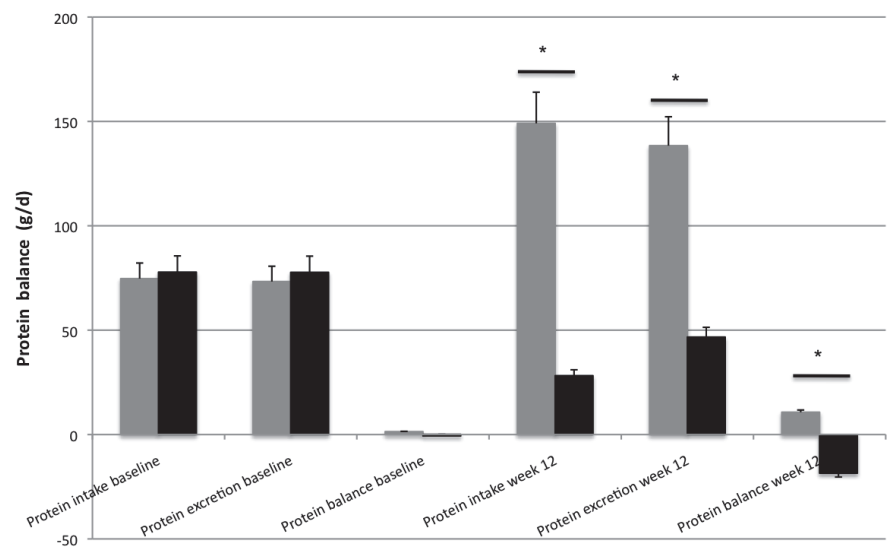

Figure 9.4 Mean ( \pm SEM) protein intake, excretion and balance at baseline and after 12 weeks on a HP (grey) vs. LP (black) diet. Data were analyzed with a two-factor repeated measures ANOVA (time $x$ treatment). *Treatment effect $P<0.001$. "Time effect $P<0.03$. Adapted and modified from Martens et al. (unpublished observations). 
Protein balance, based on protein intake and nitrogen excretion, did not differ between the HP vs. LP $(0.1 \pm 7.7$ vs. $1.4 \pm 5.1 \mathrm{~g} / \mathrm{d} ; P=0.892)$ diet groups at baseline. During the following $12 \mathrm{wk}$, protein intake and nitrogen excretion were significantly increased in the HP $(P<0.001)$ and significantly decreased in the LP $(P<0.03)$ diet group compared with baseline. Protein balance at wk 12 was positive in the HP $(10.7 \pm 5.2 \mathrm{~g} / \mathrm{d})$ and negative the LP $(-18.5 \pm 4.4 \mathrm{~g} / \mathrm{d})$.

Protein intake $(P<0.001)$ and nitrogen excretion $(P<0.01)$ were significantly different between males and females. However, protein balance did not differ between both genders $(P=0.485)$.

\section{DISCUSSION}

In the current study, continuous intravenous infusions of L-[ring- ${ }^{2} \mathrm{H}_{5}$ ]Phe and L-[ring- $\left.{ }^{2} \mathrm{H}_{2}\right]$ Tyr were used to asses whole-body protein metabolism and MPS rates in the basal fasted state, in subjects that followed either a HP diet or LP diet for 12 weeks. Prolonged adaptation to a high quantity of dietary protein intake may stimulate an increase in FFM due to the stimulation of muscle protein synthesis and/or inhibition of protein breakdown, leading to a positive protein balance (13). It could also be speculated that a protein intake below the recommended $0.8 \mathrm{~g} / \mathrm{kg}$ body weight/day for a period of three months may lead to a muscle mass loss due to the lack of sufficient precursor availability for de novo MPS (i.e. amino acids). Assessing basal whole-body protein turnover provides insight in the impact of prolonged changes in dietary protein intake on basal whole-body protein synthesis, breakdown, oxidation rates and whole-body net protein balance. The results from the present study show that whole-body protein metabolism was modulated following three months on a HP diet compared with a LP diet. Protein turnover was significantly higher with significant increases in protein synthesis, protein breakdown, and protein oxidation rates. Surprisingly, whole-body net protein balance was less negative after the LP diet when compared with the HP diet (Figure 9.2).

Whole-body phenylalanine kinetics reflect the sum of turnover rates of various tissues, these measurements of basal protein synthesis and breakdown rates do not necessarily reflect skeletal muscle tissue protein synthesis or breakdown. Therefore, we collected multiple muscle biopsies to measure fasting muscle protein FSR. As discussed above, results for whole-body protein metabolism showed a less negative net balance after the LP diet compared with the HP diet. With respect to FSR we observed no significant differences between the HP and LP group. These data seem to be in line with the whole-body data, showing that prolonged habituation to a daily dietary protein intake of less than $0.4 \mathrm{~g} / \mathrm{kg}$ body weight/d does not result in a decline in basal MPS rate. In fact, basal FSR are well maintained following these 3 months of dietary protein intake restriction. This is also in 
accordance with the body composition data, in which there were no significant changes observed over 12 weeks of dietary intervention or between both groups with respect to body weight, FFM and fat mass. Apparently, a LP diet for 3 months does not seem to compromise skeletal muscle mass maintenance and does not reduce basal whole-body protein balance nor reduce basal muscle protein synthesis rate.

Though we did not intend to assess potential gender differences in basal protein balance and fasting MPS rates, we did observe differences with respect to whole-body protein metabolism and FSR between men and women. Whereas some researchers (27-30) observed no major sex differences with respect to muscle protein synthesis rates in the post-absorptive state in men vs. women, others (31) have reported rather lower rates in men compared with women. Though there is some discrepancy in the literature, our data suggests that after correction for FFM whole-body protein synthesis and FSR were increased in women vs. men.

When comparing treatment in the fasted state with those including the postprandial state, a discrepancy of the results seems to appear. In the fasted state, reflected by whole-body phenylalanine kinetics, net protein balance is less negative on the LP diet vs. the HP diet. Including the postprandial state, as represented by the nitrogen retention data, net protein balance was more positive on the HP diet than on the LP diet. Obviously, a positive protein balance on a HP diet is completely due to the postprandial protein balances.

Finally, the present study is restricted by the evaluation of the impact of a high vs. low protein diet on whole-body protein balance and MPS rates in the basal fasted state only. It would be of interest to assess whether the prolonged changes in habitual protein intake would also modulate the muscle protein synthetic response to anabolic stimuli, such as physical activity $(32,33)$ and food intake.

In conclusion, prolonged adaptation to a high dietary protein intake increases fasting, whole-body protein turnover rates when compared with a low dietary protein intake. Whole-body protein synthesis, breakdown, and oxidation rates are increased on a high protein intake but do not result in a more positive net protein balance in the postabsorptive state. On a muscle tissue level, fasting muscle protein synthesis rates are not reduced following 3 months of adaptation to a low protein intake diet.

\section{ACKNOWLEDGEMENTS}

We gratefully acknowledge the help of Givan Paulus and Kirsten van der Beek with the collection of muscle tissue. Moreover, we would like to thank Stephan van Vliet and Stefan Camps for their assistance during the experiments. 


\section{REFERENCES}

1. Soenen S, Martens EA, Hochstenbach-Waelen A, Lemmens SG, Westerterp-Plantenga MS. Normal protein intake is required for body weight loss and weight maintenance, and elevated protein intake for additional preservation of resting energy expenditure and fat free mass. J Nutr 2013;143:591-6.

2. Westerterp-Plantenga MS, Lemmens SG, Westerterp KR. Dietary protein - its role in satiety, energetics, weight loss and health. Br J Nutr 2012;108 Suppl 2:S105-12.

3. Bray GA, Smith SR, de Jonge L, Xie H, Rood J, Martin CK, Most M, Brock C, Mancuso S, Redman LM. Effect of dietary protein content on weight gain, energy expenditure, and body composition during overeating: a randomized controlled trial. JAMA 2012;307:47-55.

4. Soenen S, Westerterp-Plantenga MS. Changes in body fat percentage during body weight stable conditions of increased daily protein intake vs. control. Physiol Behav 2010;101:635-8.

5. Cermak NM, Res PT, de Groot LC, Saris WH, van Loon L. Protein supplementation augments the adaptive response of skeletal muscle to resistance-type exercise training: a meta-analysis. Am J Clin Nutr 2012;96(6):1454-64.

6. Summerbell CD, Douthwaite W, Whittaker V, Ells L, Hillier F, Smith S, Kelly S, Edmunds LD, Macdonald I. The association between diet and physical activity and subsequent excess weight gain and obesity assessed at 5 years of age or older: a systematic review of the epidemiological evidence. Int J Obes (Lond) 2009;33 Suppl 3:S1-92.

7. Wolfe RR. Regulation of muscle protein by amino acids. J Nutr 2002;132:3219S-24S.

8. Dideriksen K, Reitelseder S, Holm L. Influence of amino acids, dietary protein, and physical activity on muscle mass development in humans. Nutrients 2013;5:852-76.

9. Symons TB, Sheffield-Moore M, Wolfe RR, Paddon-Jones D. A moderate serving of high-quality protein maximally stimulates skeletal muscle protein synthesis in young and elderly subjects. J Am Diet Assoc 2009;109:1582-6.

10. Koopman R, Verdijk L, Manders RJ, Gijsen AP, Gorselink M, Pijpers E, Wagenmakers AJ, van Loon $\mathrm{L}$. Co-ingestion of protein and leucine stimulates muscle protein synthesis rates to the same extent in young and elderly lean men. Am J Clin Nutr 2006;84:623-32.

11. Pennings B, Boirie $Y$, Senden JM, Gijsen AP, Kuipers H, van Loon L. Whey protein stimulates postprandial muscle protein accretion more effectively than do casein and casein hydrolysate in older men. Am J Clin Nutr 2011;93:997-1005.

12. van Loon LJ, Gibala MJ. Dietary protein to support muscle hypertrophy. Nestle Nutr Inst Workshop Ser 2011;69:79-95.

13. Westerterp-Plantenga MS, Nieuwenhuizen A, Tome D, Soenen S, Westerterp KR. Dietary protein, weight loss, and weight maintenance. Annual review of nutrition 2009;29:21-41.

14. Division FS. http://www.dietaryfiberfood.com/protein-requirement.php.

15. Pennings B, Groen BB, van Dijk JW, de Lange A, Kiskini A, Kuklinski M, Senden JM, van Loon LJ. Minced beef is more rapidly digested and absorbed than beef steak, resulting in greater postprandial protein retention in older men. Am J Clin Nutr 2013;98:121-8.

16. Stunkard AJ, Messick S. The three-factor eating questionnaire to measure dietary restraint, disinhibition and hunger. J Psychosom Res 1985;29:71-83.

17. Baecke JA, Burema J, Frijters JE. A short questionnaire for the measurement of habitual physical activity in epidemiological studies. Am J Clin Nutr 1982;36:936-42.

18. Harris JA, Benedict FG. A Biometric Study of Human Basal Metabolism. Proc Natl Acad Sci U S A 1918;4:370-3.

19. Westerterp KR, Donkers JH, Fredrix EW, Boekhoudt P. Energy intake, physical activity and body weight: a simulation model. Br J Nutr 1995;73:337-47.

20. Abumrad NN, Rabin D, Diamond MP, Lacy WW. Use of a heated superficial hand vein as an alternative site for the measurement of amino acid concentrations and for the study of glucose and alanine kinetics in man. Metabolism 1981;30:936-40.

21. Bergstrom J. Percutaneous needle biopsy of skeletal muscle in physiological and clinical research. Scand J Clin Lab Invest 1975;35:609-16. 
22. van Eijk HM, Rooyakkers DR, Deutz NE. Rapid routine determination of amino acids in plasma by high-performance liquid chromatography with a 2-3 microns Spherisorb ODS II column. J Chromatogr 1993;620:143-8.

23. Wolfe RR, Chinkes DL. Isotope tracers in metabolic research. New York: Wiley-Liss; 2005.

24. Husek P. Amino acid derivatization and analysis in five minutes. FEBS Lett 1991;280:354-6.

25. Dangin M, Guillet C, Garcia-Rodenas C, Gachon P, Bouteloup-Demange C, Reiffers-Magnani K, Fauquant J, Ballevre O, Beaufrere B. The rate of protein digestion affects protein gain differently during aging in humans. J Physiol 2003;549:635-44.

26. Boirie Y, Gachon P, Corny S, Fauquant J, Maubois JL, Beaufrere B. Acute postprandial changes in leucine metabolism as assessed with an intrinsically labeled milk protein. Am J Physiol 1996;271:E1083-91.

27. Fujita S, Rasmussen BB, Bell JA, Cadenas JG, Volpi E. Basal muscle intracellular amino acid kinetics in women and men. Am J Physiol Endocrinol Metab 2007;292:E77-83..

28. Jahn LA, Barrett EJ, Genco ML, Wei L, Spraggins TA, Fryburg DA. Tissue composition affects measures of postabsorptive human skeletal muscle metabolism: comparison across genders. J Clin Endocrinol Metab 1999;84:1007-10.

29. Smith GI, Atherton P, Reeds DN, Mohammed BS, Jaffery H, Rankin D, Rennie MJ, Mittendorfer B. No major sex differences in muscle protein synthesis rates in the postabsorptive state and during hyperinsulinemia-hyperaminoacidemia in middle-aged adults. Journal of applied physiology 2009;107:1308-15.

30. Smith GI, Reeds DN, Hall AM, Chambers KT, Finck BN, Mittendorfer B. Sexually dimorphic effect of aging on skeletal muscle protein synthesis. Biology of sex differences 2012;3:11.

31. Henderson GC, Dhatariya K, Ford GC, Klaus KA, Basu R, Rizza RA, Jensen MD, Khosla S, O'Brien P, Nair KS. Higher muscle protein synthesis in women than men across the lifespan, and failure of androgen administration to amend age-related decrements. FASEB journal : official publication of the Federation of American Societies for Experimental Biology 2009;23:631-41.

32. Koopman R, Pennings B, Zorenc AH, van Loon LJ. Protein ingestion further augments S6K1 phosphorylation in skeletal muscle following resistance type exercise in males. J Nutr 2007; 137:1880-6.

33. Pennings B, Koopman R, Beelen M, Senden JM, Saris WH, van Loon LJ. Exercising before protein intake allows for greater use of dietary protein-derived amino acids for de novo muscle protein synthesis in both young and elderly men. Am J Clin Nutr 2011;93:322-31. 


\section{CHAPTER 10}

General discussion 
This thesis presents a series of studies on the interaction of dietary protein with energy balance. At first, in the context of negative energy balance, evidence is provided that high-protein diets can be used as a clinical approach for body weight loss and weight maintenance (1). Yet, the emphasis of this thesis is to assess whether in neutral energy balance, dietary protein plays a role in prevention of overweight and obesity, and to reveal the relevant metabolic targets. With respect to energy intake, the question whether regulatory mechanisms prioritize the intake of protein over that of carbohydrate, fat, and total energy was studied $(2,3)$. Furthermore, attention is paid to protein intake from low-protein diets in relation to protein and indispensable amino acid (IAA) requirements $(3,4)$. The role of postprandial amino acid, glucagon-like peptide 1 (GLP-1), ghrelin, glucose and insulin concentrations as biomarkers for protein-induced satiety was addressed (5). The investigation of the other side of the energy balance equation, namely energy expenditure, assessed the transient and sustained effects of high- and low-protein diets over 12 weeks (6). Finally, elaboration on body composition, body fat distribution including ectopic fat deposition, and protein turnover aimed to assess the translation of high-protein diets as a treatment strategy into a preventive measure $(7,8)$. This chapter places the findings of these studies in a broader perspective. The clinical relevance of dietary protein for the prevention and treatment of obesity is discussed. Finally, perspectives for future research are provided.

\section{DIETARY PROTEIN AND ENERGY INTAKE}

Achieving and maintaining a negative energy balance are necessary conditions for dietary interventions to induce body weight loss. Energy-restricted high-protein diets have the potential to sustain satiety at the level of the original diet, and to sustain energy expenditure due to sparing of fat-free mass (FFM), and may therefore be applied to meet these conditions. Effects on satiety and energy expenditure were measured with a protein intake at the level of the safe requirement, defined as $0.83 \mathrm{~g} / \mathrm{kg}$ body weight/d (9). This implies that maintaining the actual protein intake at the level of a habitual diet, usually being $81-115 \mathrm{~g} / \mathrm{d}$ (10), while restricting the intake of carbohydrate and fat, is sufficient to induce body weight loss. A specific application of high-protein diets is after bariatric surgery, as protein malnutrition is a commonly observed phenomenon, postoperatively (11). In these patients, adherence to an energy-restricted relatively high-protein diet is associated with a reduction of appetite, with body weight loss, and with improvements in body composition and nutritional status. 


\section{Protein leverage}

To study whether protein intake is, in neutral energy balance, regulated more strongly than energy intake, we measured energy intake during the ad libitum consumption of diets differing in relative protein content over 12 days. We found that energy intake was not adjusted towards an individual-specific protein target intake. This would mean that regulatory mechanisms do not prioritize the intake of protein over that of total energy. Although complete protein leveraging was absent, the relatively high-protein diets elicited a strong reduction in energy intake compared with diets containing a low or normal relative protein content. Despite the lower total energy intake, subjects were similarly satiated and satisfied by the high-protein diets. Of course, it is already known from acute feeding trials that high-protein meals are highly satiating (12-16). Even a medium-term intervention study showed that an increase in dietary protein content produced a sustained decrease in ad libitum energy intake and resulted in significant body weight loss (17). The mechanism behind the reduction of energy intake by protein may be protein-induced satiety or satiation, and possibly specific effects of protein on appetite.

\section{Protein-induced satiety and satiation}

Protein-induced satiety is recognized as the inhibition of eating during the intermeal interval (18). Protein-induced satiety may be caused by a combination of elevated diet-induced thermogenesis (DIT) (19), a ketogenic state (20), anorexigenic effects of incomplete proteins $(21,22)$, appetite regulating hormones (13,23-25), and elevated dietary amino acid concentrations (13-18). We have gained evidence for the latter two.

Dietary amino acids may affect satiety signaling in the brain directly via elevated blood concentrations (26-31). According to the 'aminostatic theory', serum amino acids that cannot be channeled into protein synthesis serve as satiety signals (32). Indirectly, dietary amino acids may act on satiety signaling via receptors in the duodeno-intestinal and hepatoportal regions (33). Depending on the type of amino acid they increase or decrease the activity of hepatic vagal afferent fibers, subsequently innervating satiety signaling in the brain (33). Furthermore, plasma concentrations of (an)orexigenic gut hormones, glucose and insulin change in response to the peripheral and central detection of amino acids (34).

Belza et al. (35) showed a dose-dependent response of subjective appetite sensations and GLP-1, peptide $\mathrm{YY}$ and glucagon concentrations to preloads containing $14 \%, 25 \%$, and $50 \%$ of energy (En\%) from protein. However, most studies did not control for differences in postprandial dynamics between appetite sensations and appetite hormones.

We have assessed the within-subject relations between postprandial changes in hunger and fullness ratings, and the postprandial changes in amino acid, GLP-1, 
ghrelin, glucose and insulin concentrations following the consumption of high- and normal-protein meals $(5,36)$. First of all, we found that increases in postprandial amino acid concentrations were related to protein-induced fullness. The overall effect of amino acids on protein-induced satiety may reflect the combination of different amino acid-induced responses. It is likely that individual or groups of amino acids elicit different responses via different mechanisms (28-31). Results from our study showed that fullness ratings were especially related to concentrations of the amino acids arginine, asparagine, isoleucine, leucine, lysine, and phenylalanine (5). Mechanistic studies on these responses are mainly performed in animals, but translation into humans may be possible. When meals consist of a variety of amino acids, such as from a combination of protein sources, it is hard to distinguish the effects of single amino acids. The postprandial hunger and fullness responses to the consumption of high- and normal-protein meals were related to the postprandial kinetics of GLP-1, ghrelin, and insulin. Postprandial GLP1 , ghrelin, and insulin concentrations changed dose-dependently in response to the amount of protein in the diet. Taken together, protein-induced satiety is a combined expression with direct and indirect effects of amino acids on different systems.

Protein induced satiation relates to the inhibitory feedback from postingestive food stimuli that act to terminate eating at the end of a meal (18). Hardly any studies have assessed protein-induced satiation. The 3-arm crossover studies that we performed, with the use of ad libitum diets containing 5, 15, and 30En\% from protein, enabled assessment of protein-induced satiation. We observed that the lower total energy intake from the high-protein diets compared with the normalprotein diets was predominantly the result of a lower energy intake from meals. Energy intake from snacks between meals was comparable between the conditions. Hereby we showed a satiation effect rather than a satiety effect with high-protein diets. Acute responses of amino acids and anorexigenic hormones that elicit during the ad libitum consumption of high-protein meals may contribute to the satiation effect (2). Ultimately, humans may aim to maintain appetite over the day at a desirable level, such as that during their habitual diet (17).

\section{Protein-specific appetite}

Studies in various species observed that protein intake is regulated more strongly than the intake of carbohydrate and fat. It was hypothesized that the energy intake from unbalanced diets is adjusted as a result of specific appetites for protein (37). Born et al. (38) has shown acute food-choice compensation after high- vs. lowprotein meals in humans. A compensatory increase in carbohydrate intake was related to a decrease in liking and task-related signaling in the hypothalamus after a high-protein meal. After a low-protein meal, an increase in wanting and taskrelated signaling in the hypothalamus was related to a relative increase in protein intake in a subsequent meal (38). Griffioen-Roose et al. (39) showed in a 4-day 
study that subjects increased their protein intake in a compensatory way during ad libitum feeding after a low-protein diet (5En\% from protein). Furthermore, the quality of protein appears to be involved in hunger suppression. Low-quality gelatin-containing meals suppressed hunger more than meals containing a higherquality protein (casein, soy, whey, or whey without glycomacropeptide $(21,40)$. The intake of incomplete proteins seems to be a signal of hunger suppression rather than a satiation or satiety signal. In our 12-day intervention studies, humans did not show a specific appetite for protein. Energy intake was not differently affected with the ad libitum consumption of a low-protein diet compared with a normal-protein diet over 12 days. In general, protein-induced suppression of appetite was not affected by taste perception $(14,15,41,42)$.

In neutral energy balance, we observed that appetite profile was only differently influenced by the dietary interventions in the short-term. Ratings of fullness were higher in the high protein-low carbohydrate diet compared with the high carbohydrate-low protein diet. Translation into large changes in energy intake was not possible, because subjects had to maintain their body weight. The findings that subjects were able to keep protein intake high or low show that these intakes fall within the range in which healthy humans are capable to respond and adapt for a period of at least 12 weeks. The effects on fullness were not sustained in the longer-term. Habituation enabled maintaining food intake over the day at the prescribed level, despite differences in protein intake $(2,17)$.

\section{Nitrogen balance}

Since protein leverage is likely not the mechanism behind the regulation of energy intake on low-protein diets, we have speculated that protein is adjusted to maintain nitrogen balance and sufficient IAA intake. Compensatory intake of protein for obligatory loss of nitrogen is essential for normal growth and development in organisms $(43,44)$. The participants in our studies had a protein intake with a 5En\%-protein diet that was well below the minimal protein requirement of $0.66 \mathrm{~g} / \mathrm{kg}$ body weight/d (44). From the observation that nitrogen balance was maintained with this diet over 12 days, we suggest that humans have a wide capacity to respond and adapt to differences in protein intake in the shorttime. The Adaptive Demands model developed by Millward may provide an explanation for this observation by proposing that the metabolic demand for amino acids comprises a fixed component and a variable adaptive component (45). Shortterm changes in protein intake are likely within the adaptive range (43). Adaptations in protein and amino acid metabolism to changes in protein intake largely occur via changes in whole-body protein turnover and amino acid oxidation $(46,47)$. Changes in amino acid oxidation were reflected as decreased and increased nitrogen excretion in response to the low- and high-protein diets respectively. Nevertheless, a positive nitrogen balance was observed following high protein intake. This is in line with earlier observations $(46,48-50)$, but does not 
automatically reflect an increase in protein anabolism (43). The capacity of the body to increase amino acid anabolism through an increase in lean body mass is limited (43). Only interventions using diets high in specific IAA, such as leucine, might be able to stimulate protein synthesis in specific target groups $(51,52)$. Therefore, a transient retention or loss of body nitrogen because of a labile pool of body nitrogen may likely contribute to adaptations in amino acid metabolism in response to changes in protein intake (53).

\section{Indispensable amino acids}

The proposed mechanism to prevent a negative nitrogen balance may be related to an observed signaling pathway for the detection of amino acid depletion (22,54-61). In animals, the detection of reduced concentrations of IAA in the brain has been observed to affect protein synthesis. This subsequently led to behavioral responses including undereating diets that lack a minimal amount of IAA $(22,57,58,60)$. Although the measured protein intake with the $5 \mathrm{En} \%$-protein diet did not reach the amount necessary to meet the calculated minimal IAA requirements, we did not observe a comparable response in humans $(2,3)$. No shift towards a higher energy intake from the $5 \mathrm{En} \%$ protein diet compared with the $15 \mathrm{En} \%$ protein diet was observed $(9,10)$, showing that the insufficient amount of IAA clearly did not trigger a compensatory protein intake over 12 days. This has set the discussion about the limits of adaptation to a protein challenge acutely and over the longer-term. The protein intake of $0.4 \mathrm{~g} / \mathrm{kg}$ body weight $/ \mathrm{d}$ with the $5 \mathrm{En} \%$ protein diet would be too low to sustain long-term health. Observations from studies in developing countries show health deterioration related to low protein intake, especially of indispensible amino acids, at intakes $<0.66 \mathrm{~g} / \mathrm{kg}$ body weight $/ \mathrm{d}$ (9). Thus, although we conclude that protein intake did not compensate for an insufficient IAA intake with a low-protein diet for 12 days, we do not propose that low-protein diets are sustainable.

The digestible IAA score (DIAAS) can be applied in practice to examine protein quality of food products or mixed diets (44). Subsequently, the calculation of DIAAS enables the examination of the additional benefits of protein sources with higher quality in complementing lower-quality proteins. For regulatory purposes, protein adequacy of foods and food products sold to consumers could be classified and monitored (44).

\section{DIETARY PROTEIN AND ENERGY EXPENDITURE}

Longer-term high-protein studies have focused on body weight loss, thereby applying an energy-restriction regimen to induce a negative energy balance. It has been observed that the decline in energy expenditure and sleeping metabolic rate 
(SMR) as a result of body weight loss was less on a high-protein than on a lowprotein diet (62). Short-term intervention studies measured energy expenditure in relation to the dietary protein content in energy balance. Acutely, higher rates of energy expenditure $(63,64)$, and an initial negative energy balance $(63)$ were shown in response to energy-balanced high-protein diets. Longer-term studies in energy balance are necessary to highlight the role of protein-induced energy expenditure, to predict whether a higher protein intake plays a role in the prevention of obesity via energy expenditure. Therefore, to investigate whether the acute effects of highprotein diets in energy balance are transient or sustained, we compared the effects of a high protein-low carbohydrate with a high carbohydrate-low protein diet, at a constant body weight, over 12 weeks. We observed that energy expenditure was maintained on the high protein-low carbohydrate diet over 12 weeks. Energy expenditure decreased with the high carbohydrate-low protein diet, subsequently manifesting as a positive energy balance after the 12-week intervention. Thus, the earlier observed acute response of high protein intake on energy expenditure may be transient. At a constant body weight, high protein-low carbohydrate diet may protect against the development of a positive energy balance, rather than inducing a negative energy balance. The consumption of a high carbohydrate-low protein diet increases the risk for the development of a positive energy balance.

Comparison of the high protein-low carbohydrate diet with the high carbohydrate-low protein diet revealed diverging effects on SMR and DIT over 12 weeks. An increase in protein oxidation likely explains the small increase in DIT in response to the high protein-low carbohydrate diets, which is beneficial to sustain energy expenditure in the longer-term (65). However, it may be possible that high protein intake induces a strong acute response on DIT, followed by a smaller, but sustained effect in the longer-term. Luscombe et al. (66) showed that the acute response to a high-protein preload on DIT was significantly larger compared with a normal-protein preload, but did not differ during weight maintenance after a 16week energy-restriction diet. On the high carbohydrate-low protein diet, the amount of carbohydrates oxidized was not significantly increased, indicating that excess dietary carbohydrates were not expended as heat $(67,68)$.

\section{Body composition}

Since FFM is the main determinant of SMR, changes in body composition have a substantial impact on energy expenditure. Therefore, the potential of high-protein diets to induce body weight loss has partly been ascribed to their potential to maintain energy expenditure by preservation of FFM $(1,69)$. In line with our observations on energy expenditure, the high protein intake appeared to be a strong stimulus for preservation of FFM. Contradictory, FFM increased independently of body weight in a 12-week intervention study in which subjects were counseled to exchange $2 \mathrm{MJ}$ of their habitual energy intake with isocaloric protein supplements (70). The absence of significant increases in protein anabolism 
in response to the high-protein diet in our study may be the absence of an external stimulus such as resistance exercise $(71,72)$. The sustained positive nitrogen balance on the high protein-low carbohydrate diets corresponds with earlier observations (73). Similarly, sustained nitrogen accretion with high-protein intake was shown in nitrogen balance studies, whereas no gain of body nitrogen was measured (43). A possible explanation is the retention or loss of body nitrogen due to a labile pool of body nitrogen (53).

Another new finding of our study was the development of adaptive thermogenesis via a decrease in SMR on the high carbohydrate-low protein diet. Adaptive thermogenesis has already been shown to develop during body weight loss $(74,75)$ and was sustained during weight maintenance (76). This process may have facilitated the development of a positive energy balance on the high carbohydrate-low protein diet, which was present at week 12 .

Although the changes in protein intake with the high protein-low carbohydrate and high carbohydrate-low protein diets did not result in considerable changes in FFM, this does not mean that metabolic function was unaffected. Metabolic disturbances associated with obesity may depend on ectopic fat content, rather than visceral adipose tissue being the main determinant $(77,78)$. We have assessed the potential of a 12-week high protein-low carbohydrate diet vs. a high carbohydrate-low protein diet to modify or preserve intrahepatic triglyceride (IHTG) content, thereby excluding the possible effects metabolic disturbances and changes in body weight. IHTG content tended to be lower after the consumption of the high protein-low carbohydrate vs. the high carbohydrate-low protein diet for 12 weeks, at a constant body weight (7). The healthy, non-obese subjects had a low IHTG content at baseline, which would have exhibited a strong resistance for metabolic changes in response to dietary interventions. Nevertheless, the observations of this study are relevant by suggesting that IHTG content may be a factor contributing to the metabolically preventive effects of high-protein diets in healthy humans. In a short-term dietary intervention study, protein supplementation has been observed to blunt the increase in IHTG content due to hypercaloric high-fructose intake in healthy subjects (79). A proposed mechanism for the modulation of IHTG content by a high protein intake is the stimulation of hepatic lipid oxidation because of the high energetic demand for amino acid catabolism and ketogenesis $(80,81)$, an increased bile acid production (82), and protein-induced glucagon secretion $(83,84)$. Correspondingly, our results point towards this increased susceptibility for high-carbohydrate, low-protein intake to metabolic disturbances. Previous studies have shown a relationship between high carbohydrate intake and increased very-low-density lipoprotein TG concentrations (85-88). This may result in increases in hepatic TG, and subsequently in IHTG content (87). 


\section{Protein turnover}

Previous studies have reported that high protein intake stimulates protein synthesis and turnover, and induces a small suppression of protein breakdown (51, $89,90)$. On the other hand, it could be speculated that prolonged low protein intake leads to muscle protein loss due to the lack of precursor availability for de novo muscle protein synthesis (i.e. amino acids) $(91,92)$. The results from our study show that whole - body protein metabolism was different after a high-protein diet compared with a low-protein diet for 12 weeks (8). Protein turnover was significantly higher with significant increases in protein synthesis, protein breakdown, and protein oxidation. Surprisingly, the net protein balance was less negative after the low-protein diet compared with the high-protein diet. The observations of increased protein synthesis and breakdown in the basal fasted state differ from acute postprandial studies, which report increased protein synthesis and reduced protein breakdown (91,93-95). This may stress the role of protein breakdown in FFM accretion, which also was discussed by Wolfe et al. $(47,91)$. They observed a maximum response of protein synthesis after a single serving of 20-30 g of dietary protein, and suggested that additional effects of protein intake on FFM accretion are accounted for by the inhibition of protein breakdown. However, a beneficial reduction of protein breakdown only seems to be susceptible to acute ingestion of protein, as such changes were not apparent in the basal fasted state after prolonged high-protein intake.

Basal fractional synthetic rates were maintained throughout the 12-week protein intake restriction (8). These data seem to be in line with the whole-body data, showing that habituation to a protein intake of less than $0.4 \mathrm{~g} / \mathrm{kg}$ body weight/d does not reduce basal muscle protein synthesis rates. This is also in accordance with the body composition data, in which there were no significant changes observed over 12 weeks or between both groups with respect to body weight, FFM and fat mass. Apparently, a low-protein diet for 12 weeks is not detrimental to young healthy subjects, who might have the ability to adapt to the circumstances, most likely by limiting protein breakdown.

\section{CONCLUSIONS}

High-protein diets combined with energy restriction sustain satiety, energy expenditure and fat-free mass. However, the ad libitum consumption of highprotein diets decreases energy intake, while low-protein diets do not automatically result in an increase in energy intake over 12 days. Therefore, energy intake is not adjusted towards an individual-specific protein target intake. High-protein diets in neutral energy balance prevent the development of a positive energy balance by maintenance of energy expenditure, whereas energy-balanced low-protein diets 
increase the risk for the development of a positive energy balance through a sustained decrease in energy expenditure.

\section{PERSPECTIVES FOR FUTURE RESEARCH}

Unraveling the interaction of dietary protein with energy balance is warranted for the application of protein diets as successful preventive or treatment strategy for obesity. Some remaining issues, and several new issues based on the findings discussed in this thesis need to be addressed in future research.

In general, protein intake must still fall within a range to ensure it addresses possible shortages or excesses. Data from our studies suggest that humans have a wide capacity to respond and adapt to differences in protein intake. However, the limits for such adaptation to a protein challenge acutely and over the long-term remain to be clarified. Observations from studies in developing countries show health deterioration related to low protein intake (9). This makes it difficult to assess the effects of low-protein diets in intervention studies over a period longer than 12 weeks. However, it would be highly relevant to determine amino acid requirements for subjects fully adapted to lower than usual protein intakes (44). Furthermore, amino acid requirements in different conditions and circumstances, such as in children, pregnancy, ageing, diseases and exercise should be determined, which is necessary to develop protein intake recommendations for specific target groups.

Despite a reduction in energy requirements, protein requirements increase in the elderly as a result of age-related changes in protein metabolism (9). Protein synthesis decreases, protein breakdown increases, and there is a lower protein digestibility, subsequently resulting in a loss of muscle mass and a diminished function and strength $(51,89,90)$. High-protein diets, enriched with leucine, and preferably combined with resistance exercise may preserve body weight and muscle mass and thereby reducing functional decline in the elderly $(96,97)$. In adults, we observed that habituation in appetite enabled maintaining food intake on a high-protein diet over the day at the prescribed level (6). This mechanism may also be present in the elderly, and may lead to high adherence rates to high-protein diets.

Longer-term intervention studies with measurements of plasma amino acid concentrations, whole body protein turnover and muscle protein synthesis would provide more insight in the changes in protein and amino acid metabolism in response to dietary protein intake. With respect to high-protein diets, it remains to be determined whether diets containing protein in the order of $30 \mathrm{En} \%$ are suitable to be consumed in energy balance in the longer-term. 
Lastly, it is also relevant to implement the measurement of IHTG content as a new measure for metabolic disturbances in studies assessing the effects of highprotein diets during body weight loss and weight maintenance. 


\section{REFERENCES}

1. Martens EA, Westerterp-Plantenga MS. Protein diets, body weight loss and weight maintenance. Curr Opin Clin Nutr Metab Care 2014;17:75-9.

2. Martens EA, Lemmens SG, Westerterp-Plantenga MS. Protein leverage affects energy intake of high-protein diets in humans. Am J Clin Nutr 2013;97:86-93.

3. Martens EA, Tan SY, Dunlop MV, Mattes RD, Westerterp-Plantenga MS. Protein leverage effects of beef protein on energy intake in humans. Am J Clin Nutr 2014;99:1397-406.

4. Martens EA, Tan SY, Mattes RD, Westerterp-Plantenga MS. No protein intake compensation for insufficient indispensable amino acid intake with a low-protein diet for 12 days. Submitted

5. Martens EA, Lemmens SG, Veldhorst MA, Westerterp-Plantenga MS. Postprandial changes in appetite relate to postprandial changes in amino acid, GLP-1, ghrelin, and insulin concentrations after casein-, soy-, and whey-protein breakfasts. Submitted

6. Martens EA, Gonnissen HK, Gatta-Cherifi B, Janssens PL, Westerterp-Plantenga MS. Maintenance of energy expenditure on high-protein vs. high-carbohydrate diets at a constant body weight may prevent a positive energy balance. Submitted

7. Martens EA, Gatta-Cherifi B, Gonnissen HK, Westerterp-Plantenga MS. The potential of a high protein-low carbohydrate diet to preserve intrahepatic triglyceride content in healthy humans. Submitted

8. Hursel R, Martens EA, Gonnissen HK, Hamer HM, Senden JM, van Loon LJ, Westerterp-Plantenga MS. Prolonged adaptation to a high carbohydrate-low protein diet does not lead to a more negative whole-body protein balance when compared with a high protein-low carbohydrate diet. Submitted

9. WHO/FAO/UNU. Protein and Amino Acid Requirements in Human Nutrition. Report of a Joint WHO/FAO/UNU Expert Consultation. WHO Technical Report Series No 935. Geneva, Italy; 2007.

10. FAO Statistics Division 2010. Food Balance Sheets. Food and Agriculture Organization of the United Nations. Rome, Italy. Version current March 2011. Available from http://faostat.fao.org/ (assessed 13 May 2014).

11. Faria SL, Faria OP, Buffington C, de Almeida Cardeal M, Ito MK. Dietary protein intake and bariatric surgery patients: a review. Obes Surg 2011;21:1798-805.

12. Halton TL, Hu FB. The effects of high protein diets on thermogenesis, satiety and weight loss: a critical review. J Am Coll Nutr 2004;23:373-85.

13. Leidy HJ, Armstrong CL, Tang M, Mattes RD, Campbell WW. The influence of higher protein intake and greater eating frequency on appetite control in overweight and obese men. Obesity (Silver Spring) 2010;18:1725-32.

14. Veldhorst MAB, Nieuwenhuizen AG, Hochstenbach-Waelen A, Westerterp KR, Engelen MPKJ, Brummer RJM, Deutz NEP, Westerterp-Plantenga MS. Effects of high and normal soyprotein breakfasts on satiety and subsequent energy intake, including amino acid and 'satiety' hormone responses. European Journal of Nutrition 2009;48:92-100.

15. Veldhorst MAB, Nieuwenhuizen AG, Hochstenbach-Waelen A, Westerterp KR, Engelen MPKJ, Brummer RJM, Deutz NEP, Westerterp-Plantenga MS. Comparison of the effects of a high- and normal-casein breakfast on satiety, 'satiety' hormones, plasma amino acids and subsequent energy intake. British Journal of Nutrition 2009;101:295-303.

16. Westerterp-Plantenga MS, Lemmens SG, Westerterp KR. Dietary protein - its role in satiety, energetics, weight loss and health. British Journal of Nutrition 2012;108:S105-S12.

17. Weigle DS, Breen PA, Matthys CC, Callahan HS, Meeuws KE, Burden VR, Purnell JQ. A high-protein diet induces sustained reductions in appetite, ad libitum caloric intake, and body weight despite compensatory changes in diurnal plasma leptin and ghrelin concentrations. Am J Clin Nutr 2005;82:41-8.

18. Langhans W, Geary N. Overview of the physiological control of eating. In: Langhans W, Geary N (eds). Frontiers in Eating and Weight Regulation. Forum Nutr. Karger: Basel; 2010.

19. Westerterp-Plantenga MS, Rolland V, Wilson SA, Westerterp KR. Satiety related to $24 \mathrm{~h}$ dietinduced thermogenesis during high protein/carbohydrate vs high fat diets measured in a respiration chamber. Eur J Clin Nutr 1999;53:495-502. 
20. Veldhorst MAB, Westerterp KR, Westerterp-Plantenga MS. Gluconeogenesis and protein-induced satiety. British Journal of Nutrition 2012;107:595-600.

21. Veldhorst MA, Nieuwenhuizen AG, Hochstenbach-Waelen A, Westerterp KR, Engelen MP, Brummer RJ, Deutz NE, Westerterp-Plantenga MS. A breakfast with alpha-lactalbumin, gelatin, or gelatin + TRP lowers energy intake at lunch compared with a breakfast with casein, soy, whey, or whey-GMP. Clin Nutr 2009;28:147-55.

22. Gietzen DW, Hao S, Anthony TG. Mechanisms of food intake repression in indispensable amino acid deficiency. Annu Rev Nutr 2007;27:63-78.

23. Batterham RL, Heffron H, Kapoor S, Chivers JE, Chandarana K, Herzog H, Le Roux CW, Thomas EL, Bell JD, Withers DJ. Critical role for peptide YY in protein-mediated satiation and body-weight regulation. Cell Metab 2006;4:223-33.

24. Blom WA, Lluch A, Stafleu A, Vinoy S, Holst JJ, Schaafsma G, Hendriks HF. Effect of a high-protein breakfast on the postprandial ghrelin response. Am J Clin Nutr 2006;83:211-20.

25. Lejeune MP, Westerterp KR, Adam TC, Luscombe-Marsh ND, Westerterp-Plantenga MS. Ghrelin and glucagon-like peptide 1 concentrations, 24-h satiety, and energy and substrate metabolism during a high-protein diet and measured in a respiration chamber. Am J Clin Nutr 2006;83:89-94.

26. Morrison CD, Reed SD, Henagan TM. Homeostatic regulation of protein intake: in search of a mechanism. Am J Physiol Regul Integr Comp Physiol 2012;302:R917-28.

27. Fromentin G, Darcel N, Chaumontet C, Marsset-Baglieri A, Nadkarni N, Tome D. Peripheral and central mechanisms involved in the control of food intake by dietary amino acids and proteins. Nutr Res Rev 2012;25:29-39.

28. Acheson KJ, Blondel-Lubrano A, Oguey-Araymon S, Beaumont M, Emady-Azar S, Ammon-Zufferey C, Monnard I, Pinaud S, Nielsen-Moennoz C, Bovetto L. Protein choices targeting thermogenesis and metabolism. Am J Clin Nutr 2011;93:525-34.

29. Hall WL, Millward DJ, Long SJ, Morgan LM. Casein and whey exert different effects on plasma amino acid profiles, gastrointestinal hormone secretion and appetite. Br J Nutr 2003;89:239-48.

30. Veldhorst MA, Nieuwenhuizen AG, Hochstenbach-Waelen A, van Vught AJ, Westerterp KR, Engelen MP, Brummer RJ, Deutz NE, Westerterp-Plantenga MS. Dose-dependent satiating effect of whey relative to casein or soy. Physiol Behav 2009;96:675-82.

31. Veldhorst MA, Nieuwenhuizen AG, Hochstenbach-Waelen A, Westerterp KR, Engelen MP, Brummer RJ, Deutz NE, Westerterp-Plantenga MS. Comparison of the effects of a high- and normal-casein breakfast on satiety, 'satiety' hormones, plasma amino acids and subsequent energy intake. Br J Nutr 2009;101:295-303.

32. Mellinkoff SM, Frankland M, Boyle D, Greipel M. Relationship between serum amino acid concentration and fluctuations in appetite. J Appl Physiol 1956;8:535-8.

33. Niijima A, Torii K, Uneyama H. Role played by vagal chemical sensors in the hepato-portal region and duodeno-intestinal canal: An electrophysiological study. Chemical Senses 2005;30:1178-19.

34. Delzenne N, Blundell J, Brouns F, Cunningham K, De Graaf K, Erkner A, Lluch A, Mars M, Peters HP, Westerterp-Plantenga M. Gastrointestinal targets of appetite regulation in humans. Obes Rev 2010;11:234-50.

35. Belza A, Ritz C, Sorensen MQ, Holst JJ, Rehfeld JF, Astrup A. Contribution of gastroenteropancreatic appetite hormones to protein-induced satiety. Am J Clin Nutr 2013;97:980-9.

36. Lemmens SG, Martens EA, Kester AD, Westerterp-Plantenga MS. Changes in gut hormone and glucose concentrations in relation to hunger and fullness. Am J Clin Nutr 2011;94:717-25.

37. Simpson SJ, Raubenheimer D. The nature of nutrition. A unifying framework from animal adaptation to human obesity. Princeton, New Jersey: Princeton Universit Press; 2012.

38. Born JM, Martens MJ, Lemmens SG, Goebel R, Westerterp-Plantenga MS. Protein v. carbohydrate intake differentially affects liking- and wanting-related brain signalling. Br J Nutr 2013;109:376-81.

39. Griffioen-Roose S, Mars M, Siebelink E, Finlayson G, Tome D, de Graaf C. Protein status elicits compensatory changes in food intake and food preferences. Am J Clin Nutr 2012;95:32-8.

40. Hochstenbach-Waelen A, Westerterp-Plantenga MS, Veldhorst MA, Westerterp KR. Single-protein casein and gelatin diets affect energy expenditure similarly but substrate balance and appetite differently in adults. J Nutr 2009;139:2285-92. 
41. Veldhorst MA, Nieuwenhuizen AG, Hochstenbach-Waelen A, Westerterp KR, Engelen MP, Brummer RJ, Deutz NE, Westerterp-Plantenga MS. Effects of complete whey-protein breakfasts versus whey without GMP-breakfasts on energy intake and satiety. Appetite 2009;52:388-95.

42. Nieuwenhuizen AG, Hochstenbach-Waelen A, Veldhorst MA, Westerterp KR, Engelen MP, Brummer RJ, Deutz NE, Westerterp-Plantenga MS. Acute effects of breakfasts containing alphalactalbumin, or gelatin with or without added tryptophan, on hunger, 'satiety' hormones and amino acid profiles. Br J Nutr 2009;101:1859-66.

43. Millward DJ. Identifying recommended dietary allowances for protein and amino acids: a critique of the 2007 WHO/FAO/UNU report. Br J Nutr 2012;108 Suppl 2:S3-21.

44. FAO. Dietary protein quality evaluation in human nutrition. Report of an Food and Agriculture Organization Expert Consultation. FAO Food and Nutrition paper 92. Rome, Italy; 2013.

45. Millward DJ. An adaptive metabolic demand model for protein and amino acid requirements. $\mathrm{Br} \mathrm{J}$ Nutr 2003;90:249-60.

46. Tome D, Bos C. Dietary protein and nitrogen utilization. J Nutr 2000;130:1868S-73S.

47. Deutz NE, Wolfe RR. Is there a maximal anabolic response to protein intake with a meal? Clin Nutr 2013;32:309-13.

48. Garlick PJ, McNurlan MA, Patlak CS. Adaptation of protein metabolism in relation to limits to high dietary protein intake. Eur J Clin Nutr 1999;53 Suppl 1:S34-43.

49. Price GM, Halliday D, Pacy PJ, Quevedo MR, Millward DJ. Nitrogen homeostasis in man: influence of protein intake on the amplitude of diurnal cycling of body nitrogen. Clin Sci (Lond) 1994;86: 91-102.

50. Pannemans DL, Halliday D, Westerterp KR, Kester AD. Effect of variable protein intake on wholebody protein turnover in young men and women. Am J Clin Nutr 1995;61:69-74.

51. van Loon LJ. Leucine as a pharmaconutrient in health and disease. Curr Opin Clin Nutr Metab Care 2012;15:71-7.

52. Millward DJ. Knowledge gained from studies of leucine consumption in animals and humans. J Nutr 2012;142:2212S-9S.

53. Munro HN. General aspects of the regulation of protein metabolism by hormones. Academic Press: New York; 1964.

54. Aparecida de Franca S, Dos Santos MP, Garofalo MA, Navegantes LC, Kettelhut Ido C, Lopes CF, Kawashita NH. Low protein diet changes the energetic balance and sympathetic activity in brown adipose tissue of growing rats. Nutrition 2009;25:1186-92.

55. Du FY, Higginbotham DA, White BD. Food intake, energy balance and serum leptin concentrations in rats fed low-protein diets. Journal of Nutrition 2000;130:514-21.

56. Gietzen DW, Rogers QR. Nutritional homeostasis and indispensable amino acid sensing: a new solution to an old puzzle. Trends Neurosci 2006;29:91-9.

57. Hao S, Sharp JW, Ross-Inta CM, McDaniel BJ, Anthony TG, Wek RC, Cavener DR, McGrath BC, Rudell JB, Koehnle TJ, et al. Uncharged tRNA and sensing of amino acid deficiency in mammalian piriform cortex. Science 2005;307:1776-8.

58. Maurin AC, Jousse C, Averous J, Parry L, Bruhat A, Cherasse Y, Zeng H, Zhang Y, Harding HP, Ron D, et al. The GCN2 kinase biases feeding behavior to maintain amino acid homeostasis in omnivores. Cell Metab 2005;1:273-7.

59. Meyer $\mathrm{JH}$. Interactions of dietary fiber and protein on food intake and body composition of growing rats. Am J Physiol 1958;193:488-94.

60. Ross CM, Sharp JW, Gietzen DW. elF2 alpha related signaling of amino acid deficiency in brain areas. Faseb Journal 2004;18:A145.

61. White BD, Porter MH, Martin PJ. Protein selection, food intake, and body composition in response to the amount of dietary protein. Physiology \& Behavior 2000;69:383-9.

62. Whitehead JM, McNeill G, Smith JS. The effect of protein intake on 24-h energy expenditure during energy restriction. Int J Obes Relat Metab Disord 1996;20:727-32.

63. Mikkelsen PB, Toubro S, Astrup A. Effect of fat-reduced diets on 24-h energy expenditure: comparisons between animal protein, vegetable protein, and carbohydrate. Am J Clin Nutr 2000;72:1135-41. 
64. Veldhorst MA, Westerterp KR, van Vught AJ, Westerterp-Plantenga MS. Presence or absence of carbohydrates and the proportion of fat in a high-protein diet affect appetite suppression but not energy expenditure in normal-weight human subjects fed in energy balance. $\mathrm{Br} J$ Nutr 2010;104:1395-405.

65. Westerterp KR. Diet induced thermogenesis. Nutr Metab (Lond) 2004;1:5.

66. Luscombe ND, Clifton PM, Noakes M, Farnsworth E, Wittert G. Effect of a high-protein, energyrestricted diet on weight loss and energy expenditure after weight stabilization in hyperinsulinemic subjects. Int J Obes Relat Metab Disord 2003;27:582-90.

67. Stock MJ. Gluttony and thermogenesis revisited. Int J Obes Relat Metab Disord 1999;23:1105-17.

68. Miller DS, Mumford P, Stock MJ. Gluttony. 2. Thermogenesis in overeating man. Am J Clin Nutr 1967;20:1223-9.

69. Soenen S, Martens EA, Hochstenbach-Waelen A, Lemmens SG, Westerterp-Plantenga MS. Normal protein intake is required for body weight loss and weight maintenance, and elevated protein intake for additional preservation of resting energy expenditure and fat free mass. J Nutr 2013;143:591-6.

70. Soenen S, Plasqui G, Smeets AJ, Westerterp-Plantenga MS. Protein intake induced an increase in exercise stimulated fat oxidation during stable body weight. Physiol Behav 2010;101:770-4.

71. Tipton KD, Phillips SM. Dietary protein for muscle hypertrophy. Nestle Nutr Inst Workshop Ser 2013;76:73-84.

72. Phillips SM, Hartman JW, Wilkinson SB. Dietary protein to support anabolism with resistance exercise in young men. J Am Coll Nutr 2005;24:134S-9S.

73. Fuller MF, Garlick PJ. Human amino acid requirements: can the controversy be resolved? Annu Rev Nutr 1994;14:217-41.

74. Tremblay A, Royer MM, Chaput JP, Doucet E. Adaptive thermogenesis can make a difference in the ability of obese individuals to lose body weight. Int J Obes (Lond) 2013;37:759-64.

75. Muller MJ, Bosy-Westphal A. Adaptive thermogenesis with weight loss in humans. Obesity (Silver Spring) 2013;21:218-28.

76. Camps SG, Verhoef SP, Westerterp KR. Weight loss, weight maintenance, and adaptive thermogenesis. Am J Clin Nutr 2013;97:990-4.

77. Fabbrini E, Magkos F, Mohammed BS, Pietka T, Abumrad NA, Patterson BW, Okunade A, Klein S. Intrahepatic fat, not visceral fat, is linked with metabolic complications of obesity. Proc Natl Acad Sci U S A 2009;106:15430-5.

78. Magkos F, Fabbrini E, Mohammed BS, Patterson BW, Klein S. Increased whole-body adiposity without a concomitant increase in liver fat is not associated with augmented metabolic dysfunction. Obesity (Silver Spring) 2010;18:1510-5.

79. Theytaz F, Noguchi Y, Egli L, Campos V, Buehler T, Hodson L, Patterson BW, Nishikata N, Kreis R, Mittendorfer $B$, et al. Effects of supplementation with essential amino acids on intrahepatic lipid concentrations during fructose overfeeding in humans. Am J Clin Nutr 2012;96:1008-16.

80. Veldhorst MA, Westerterp-Plantenga MS, Westerterp KR. Gluconeogenesis and energy expenditure after a high-protein, carbohydrate-free diet. Am J Clin Nutr 2009;90:519-26.

81. Westerterp-Plantenga MS, Lemmens SG, Westerterp KR. Dietary protein - its role in satiety, energetics, weight loss and health. Br J Nutr 2012;108 Suppl 2:S105-12.

82. Watanabe M, Houten SM, Wang L, Moschetta A, Mangelsdorf DJ, Heyman RA, Moore DD, Auwerx J. Bile acids lower triglyceride levels via a pathway involving FXR, SHP, and SREBP-1c. J Clin Invest 2004;113:1408-18.

83. Torres N, Tovar AR. The role of dietary protein on lipotoxicity. Nutr Rev 2007;65:S64-8.

84. Gannon MC, Nuttall JA, Damberg G, Gupta V, Nuttall FQ. Effect of protein ingestion on the glucose appearance rate in people with type 2 diabetes. J Clin Endocrinol Metab 2001;86:1040-7.

85. Agius L. High-carbohydrate diets induce hepatic insulin resistance to protect the liver from substrate overload. Biochem Pharmacol 2013;85:306-12.

86. Hudgins LC, Hellerstein MK, Seidman CE, Neese RA, Tremaroli JD, Hirsch J. Relationship between carbohydrate-induced hypertriglyceridemia and fatty acid synthesis in lean and obese subjects. J Lipid Res 2000;41:595-604. 
87. Schwarz JM, Neese RA, Turner S, Dare D, Hellerstein MK. Short-term alterations in carbohydrate energy intake in humans. Striking effects on hepatic glucose production, de novo lipogenesis, lipolysis, and whole-body fuel selection. J Clin Invest 1995;96:2735-43.

88. Hudgins LC, Hellerstein M, Seidman C, Neese R, Diakun J, Hirsch J. Human fatty acid synthesis is stimulated by a eucaloric low fat, high carbohydrate diet. J Clin Invest 1996;97:2081-91.

89. Tang JE, Phillips SM. Maximizing muscle protein anabolism: the role of protein quality. Curr Opin Clin Nutr Metab Care 2009;12:66-71.

90. Gilbert JA, Bendsen NT, Tremblay A, Astrup A. Effect of proteins from different sources on body composition. Nutr Metab Cardiovasc Dis 2011;21 Suppl 2:B16-31.

91. Symons TB, Sheffield-Moore M, Wolfe RR, Paddon-Jones D. A moderate serving of high-quality protein maximally stimulates skeletal muscle protein synthesis in young and elderly subjects. J Am Diet Assoc 2009;109:1582-6.

92. Dideriksen K, Reitelseder S, Holm L. Influence of amino acids, dietary protein, and physical activity on muscle mass development in humans. Nutrients 2013;5:852-76.

93. Greenhaff PL, Karagounis LG, Peirce N, Simpson EJ, Hazell M, Layfield R, Wackerhage H, Smith K, Atherton $P$, Selby $A$, et al. Disassociation between the effects of amino acids and insulin on signaling, ubiquitin ligases, and protein turnover in human muscle. Am J Physiol Endocrinol Metab 2008;295:E595-604.

94. Flakoll PJ, Kulaylat M, Frexes-Steed M, Hourani H, Brown LL, Hill JO, Abumrad NN. Amino acids augment insulin's suppression of whole body proteolysis. Am J Physiol 1989;257:E839-47.

95. Louard RJ, Barrett EJ, Gelfand RA. Overnight branched-chain amino acid infusion causes sustained suppression of muscle proteolysis. Metabolism 1995;44:424-9.

96. Volpi E, Campbell WW, Dwyer JT, Johnson MA, Jensen GL, Morley JE, Wolfe RR. Is the optimal level of protein intake for older adults greater than the recommended dietary allowance? J Gerontol A Biol Sci Med Sci 2013;68:677-81.

97. Wolfe RR. The role of dietary protein in optimizing muscle mass, function and health outcomes in older individuals. Br J Nutr 2012;108 Suppl 2:S88-93. 
Summary 
Chronic positive energy balance is the mechanism underlying the development of obesity and its associated health problems, such as type 2 diabetes and cardiovascular diseases. Since the prevalence of obesity has reached epidemic proportions, high-protein diets have come into focus as being beneficial strategies for body weight loss and weight maintenance thereafter. Yet, the emphasis of this thesis is to assess whether dietary protein plays a role in prevention of overweight and obesity, and to reveal the relevant metabolic targets. Therefore, this thesis presents a series of studies on the interaction of dietary protein with energy balance.

At first, evidence is provided that high-protein diets can be used as a clinical approach for body weight loss and weight maintenance in a negative energy balance. Energy-restricted high-protein diets have the potential to sustain satiety at the level of the original diet, and to sustain energy expenditure due to sparing of fat-free mass. Maintaining the actual protein intake (in $\mathrm{g} / \mathrm{kg}$ body weight/d) at the level of a habitual diet, while restricting the intake of carbohydrate and fat, was sufficient to induce body weight loss.

In the context of the protein leverage hypothesis, it was studied whether protein intake was, in neutral energy balance, regulated more strongly than energy intake. Energy intake during the ad libitum consumption of diets differing in relative protein content was measured over 12 days. Although complete protein leveraging was absent, the relatively high-protein diets elicited a strong reduction in energy intake compared with diets containing a low or normal relative protein content. No shift towards a higher energy intake from the low-protein diet compared with the normal-protein diet was observed. Subsequently, it was determined whether protein intake on low-protein diets was adjusted to maintain nitrogen balance and sufficient indispensable amino acid (IAA) intake. Compensatory intake of protein for obligatory loss of nitrogen is essential for normal growth and development in organisms. The observation that nitrogen balance was maintained with a low-protein diet over 12 days suggests that humans have the capacity to respond and adapt to differences in protein intake in the short-term. Adaptations in protein and amino acid metabolism to changes in protein intake largely occur via changes in whole-body protein turnover and amino acid oxidation. Changes in amino acid oxidation were reflected as decreased and increased nitrogen excretion in response to the low- and high-protein diets respectively. A transient retention or loss of body nitrogen because of a labile pool of body nitrogen likely contributes to adaptations in amino acid metabolism in response to changes in protein intake. The measured protein intake with the lowprotein diet did not reach the amount necessary to meet the calculated minimal IAA requirements, showing that the insufficient amount of IAA did not trigger a compensatory intake over 12 days. This has set the discussion about the limits of adaptation to a protein challenge acutely and over the longer-term. 
The mechanism behind the effects of protein on energy intake may be proteininduced satiety or satiation, and possibly specific effects of protein on appetite. A specific appetite for protein was not observed with the 12-day low-protein diet. The reduction in energy intake with the high-protein diets compared with the normal-protein diets was predominantly the result of a lower energy intake from meals. Hereby, a satiation effect rather than a satiety effect was shown. The withinsubject relations between postprandial changes in hunger and fullness ratings, and the postprandial changes in amino acid, glucagon-like peptide (GLP)-1, ghrelin, glucose and insulin concentrations were assessed following the consumption of single high- and normal-protein meal challenges. First of all, increases in postprandial amino acid concentrations were related to protein-induced fullness. Fullness ratings were especially related to concentrations of the amino acids arginine, asparagine, isoleucine, leucine, lysine, and phenylalanine. Furthermore, the postprandial hunger and fullness responses to the consumption of high- and normal-protein meals were related to the postprandial kinetics of GLP-1, ghrelin, and insulin. Postprandial GLP-1, ghrelin, and insulin concentrations changed dosedependently in response to the amount of protein in the diet. Taken together, protein-induced satiety is a combined expression with direct and indirect effects of amino acids on different systems.

The investigation of the other side of the energy balance equation, namely energy expenditure, assessed the transient and sustained effects of high- and lowprotein diets over 12 weeks. Furthermore, elaboration on body composition, including ectopic fat deposition, and protein turnover aimed to assess the translation of high-protein diets as a treatment strategy into a preventive measure. In neutral energy balance, protein-induced fullness was only manifested in the short-term, whereas a diverging effect on energy expenditure was observed over 12 weeks. Habituation to the satiating properties of protein enabled the consumption of a high-protein diet in energy balance, if required to maintain body weight. An increase in protein oxidation in response to the high protein-low carbohydrate diets likely explains the small increase in diet-induced thermogenesis, which is beneficial to sustain energy expenditure in the longer-term. The development of adaptive thermogenesis via a decrease in sleeping metabolic rate on the high carbohydrate-low protein diet may have facilitated the development of a positive energy balance, which was present at week 12 .

Although the changes in protein intake with the high protein-low carbohydrate and high carbohydrate-low protein diets did not result in considerable changes in fat-free mass, this does not mean that metabolic function was unaffected. Intrahepatic triglyceride content tended to be lower after the consumption of the high protein-low carbohydrate vs. the high carbohydrate-low protein diet for 12 weeks, at a constant body weight. These results point towards an increased susceptibility for high-carbohydrate, low-protein intake to metabolic disturbances. 
Moreover, protein turnover in the basal fasted state was higher with increases in protein synthesis, - breakdown, and - oxidation after prolonged high protein intake compared with low protein intake. Surprisingly, the net protein balance was less negative after the high carbohydrate-low protein diet compared with the high protein-low carbohydrate diet. Thus, a beneficial reduction of protein breakdown only seems to be susceptible to acute ingestion of protein.

In conclusion, the interaction of dietary protein with energy balance contributes to understand the potential of high-protein diets to prevent obesity by acting on energy intake and energy expenditure. On the other hand, it highlights the susceptibility of low-protein diet consumers for the development of metabolic disturbances related to effects on energy expenditure and ectopic fat deposition. 
Samenvatting 
Obesitas ontstaat door een langdurige positieve energiebalans, en gaat vaak gepaard met gezondheidsproblemen zoals type 2 diabetes en hart- en vaatziekten. Door de sterke toename in de prevalentie van obesitas zijn hoog-eiwitdieten populair geworden als manier om gewichtsverlies en -behoud te bevorderen. In deze thesis ligt de nadruk op het onderzoek of eiwitten in de voeding een rol spelen bij het voorkómen van overgewicht en obesitas, en welke metabole processen daarbij mogelijk een rol spelen. De thesis beschrijft een reeks van onderzoeken naar de interactie tussen eiwitten in de voeding en de energiebalans.

Allereerst werd bevestigd dat hoog-eiwitdieten toegepast kunnen worden als manier om gewichtsverlies en -behoud te bevorderen gedurende een negatieve energiebalans. Energiebeperkte hoog-eiwit diëten handhaven het verzadigingsgevoel, de vetvrije massa, en daarmee het energiegebruik op het oorspronkelijke niveau. Met het handhaven van de eiwitinname (in $\mathrm{g} / \mathrm{kg}$ lichaamsgewicht/d) op het oorspronkelijke niveau, en een vermindering van de inname van koolhydraten en vetten kan gewichtsverlies bewerkstelligd worden.

In de situatie van een neutrale energiebalans werd onderzocht of de eiwitinname sterker gereguleerd wordt dan de energie-inname. Dit mechanisme is beschreven als de 'protein leverage' hypothese. Gedurende perioden van 12 dagen werd de energie-inname gemeten tijdens de ad libitum consumptie van diëten die verschilden in de relatieve hoeveelheid eiwit. Hoewel geen volledige hefboomwerking van eiwitinname ten aanzien van energie-inname optrad, verminderde de energie-inname sterk tijdens de hoog-eiwitdiëten versus de normaal- en laag-eiwitdiëten. Een hefboomwerking van een lagere eiwitinname naar een hogere energie-inname werd niet waargenomen. Dit verschijnsel was onafhankelijk van het soort eiwit: wei, soja of rundvleeseiwit. Vervolgens werd bepaald of de eiwitinname tijdens laag-eiwitdiëten aangepast werd om de stikstofbalans te handhaven en voldoende essentiële aminozuren te consumeren. De waarneming dat de stikstofbalans gedurende de 12-daagse interventie behouden bleef suggereert dat het menselijk lichaam zich gedurende een kortere periode kan aanpassen aan een veranderde eiwitinname. Bovendien was de eiwitinname met het laag-eiwitdieet niet voldoende om aan de aanbevolen hoeveelheid essentiële aminozuren te voldoen. Hiermee werd aangetoond dat een te lage inname van essentiële aminozuren niet leidt tot een verhoogde voedselinname gedurende 12 dagen om toch aan de aanbevolen hoeveelheid aminozuren te kunnen voldoen. Deze waarnemingen zijn interessant voor vervolgonderzoek naar de grenzen aan aanpassing aan acute en langdurige veranderingen in eiwitinname.

Mogelijke mechanismen waarop eiwitten de energie-inname beinvloeden zijn eiwit-geïnduceerde verzadiging of een verminderde eetlust. Een specifieke eetlust voor eiwit is niet waargenomen met het 12 -daagse laag-eiwitdieet. De verminderde energie-inname met de maaltijden van de hoog-eiwitdiëten vergeleken met de normaal-eiwitdiëten is voornamelijk te wijten aan een acuut verzadigingseffect 
tijdens het consumeren van de maaltijden. Van een langdurig verhoogd verzadigingsgevoel tussen de maaltijden door was geen sprake.

Een ander onderzoek betrof de relaties tussen postprandiale veranderingen in gevoelens van honger en verzadiging, en de postprandiale veranderingen in aminozuur-, glucagon-like peptide (GLP)-1-, ghreline- en insulineconcentraties. Deze werden direct na het consumeren van maaltijden die een hoog of een normaal eiwitgehalte bevatten bepaald voor alle proefpersonen afzonderlijk. Allereerst, de toename in postprandiale aminozuurconcentraties was gerelateerd aan een toename in de eiwit-geïnduceerde verzadiging. Deze toename in verzadiging was voornamelijk gerelateerd aan verhogingen van de concentraties van de aminozuren arginine, asparagine, isoleucine, leucine, lysine en fenylalanine. Bovendien waren de afname van de honger en de toename van de verzadiging gerelateerd aan veranderingen in de concentraties van GLP-1, ghreline en insuline in het plasma. Postprandiale GLP-1-, ghreline- en insulineconcentraties vertoonden een dosis-respons relatie met de hoeveelheid eiwitten in de voeding. Samengevat, eiwit-geïnduceerde verzadiging is het resultaat van directe en indirecte effecten van aminozuren op verschillende mechanismen.

Met het onderzoeken van de andere kant van de energiebalans, namelijk het energiegebruik, werden de tijdelijke en langdurige effecten van hoog- en laageiwitdiëten bepaald over een periode van 12 weken. Aan de hand van metingen van de lichaamssamenstelling, waaronder ectopische vetopslag, en eiwitturnover werd onderzocht of hoog-eiwitdiëten naast het bevorderen van gewichtsverlies ook een toegepast kunnen worden om een positieve energiebalans tegen te gaan. Eiwit-geïnduceerde verzadiging werd echter alleen waargenomen op de korte termijn, terwijl een divergerend, langetermijneffect van eiwit op het energiegebruik waargenomen werd. Gewenning aan de verzadigende werking van eiwit maakte het mogelijk om een hoog-eiwitdieet in energiebalans te consumeren, wanneer het lichaamsgewicht behouden diende te blijven. Wel werd, in tegenstelling tot bij het hoog koolhydraatlaag-eiwitdieet, behoud van het oorspronkelijke energiegebruik waargenomen. Dit werd verklaard door een toename in de dieet-geïnduceerde thermogenese, gebaseerd op een toename in de eiwitoxidatie. Het consumeren van een hoog koolhydraat-laag eiwitdieet resulteerde in het ontstaan van adaptieve thermogenese via een afname in het metabolisme zoals gemeten wordt tijdens het slapen. Dit mechanisme kan bijgedragen hebben aan het ontstaan van de positieve energiebalans na het consumeren van een hoog koolhydraat-laag eiwitdieet gedurende 12 weken.

Het uitblijven van grote veranderingen in de vetvrije massa met het consumeren van de hoog eiwitlaag koolhydraat en hoog koolhydraatlaag eiwitdiëten betekent niet dat de metabole processen onveranderd zijn gebleven. Een trend voor een lager levervetgehalte na het consumeren van een hoog eiwitlaag koolhydraatdieet vergeleken met een hoog koolhydraat-laag eiwitdieet werd waargenomen na 12 weken, bij een constant lichaamsgewicht. Deze bevinding 
suggereert dat het consumeren van een hoog koolhydraatlaag eiwitdieet de gevoeligheid voor het ontwikkelen van metabole verstoringen vergroot.

$\mathrm{Na}$ de langdurige hoge eiwitinname was de eiwitturnover in de basale, gevaste toestand verhoogd door een vergroting van de eiwitsynthese, -afbraak, en oxidatie. Echter, de netto eiwitbalans was minder negatief na het consumeren van een hoog koolhydraat-laag eiwitdieet vergeleken met een hoog koolhydraat-laag eiwitdieet. Dit suggereert dat de verminderde eiwitafbraak alleen waarneembaar is als acute reactie op eiwitinname. De netto positieve 24-uurs eiwitbalans wordt dus volledig verklaard worden door eiwitsynthese in de gevoede situatie.

Concluderend, onderzoek naar de interactie tussen eiwitten in de voeding en de energiebalans biedt inzicht in de manier waarop hoog-eiwitdiëten, via het beïnvloeden van de energie-inname en het energiegebruik, preventief zijn voor het ontstaan van obesitas. Zij die laag-eiwitdiëten consumeren blijken gevoelig te zijn voor de ontwikkeling van metabole verstoringen die gerelateerd zijn aan ongunstige effecten op het energiegebruik en de ectopische vetopslag. 
Valorisation 


\section{THE TRANSLATION OF SCIENTIFIC KNOWLEDGE INTO PRACTICE}

Overweight and obesity are defined as abnormal or excessive fat accumulation that may impair health (1). In 2008, more than 1.4 billion adults aged 20 and older were overweight worldwide. Of these, over 200 million men and nearly 300 million women were obese. Overweight and obesity are associated with health problems such as type 2 diabetes, cardiovascular diseases and certain cancers. Consequently, these conditions are leading risks for global deaths. Around 3.4 million adults die each year as a result of being overweight or obese. Apart from premature death, the health consequences include serious chronic conditions that reduce the quality of life at the individual level (2). Furthermore, the epidemic proportions of overweight and overweight-related conditions have a large economic impact. In the Netherlands, overweight was responsible for 2 milliard euro on medical and social costs in 2010 (3).

Body weight loss followed by weight maintenance is essential in the treatment of overweight and obesity. Nationally, efforts to implement interventions on body weight management have been made for many years. Furthermore, the World Health Organization began organizing expert and technical consultations on obesity in the 1990s. Public awareness campaigns were initiated to sensitize policy makers, private sector partners, medical professionals and the public at large. On the other hand, obesity is the focus of many scientific studies for several decades.

This thesis is part of the large body of scientific knowledge on obesity and obesity-related health problems. It presents the results and conclusions of scientific research on the interaction of dietary protein with energy balance. These add to the understanding of how protein intake affects energy intake and energy expenditure. From our studies we conclude that high-protein diets would be a concept for the prevention and treatment of obesity because they have the potential to prevent overconsumption and to maintain energy expenditure. On the other hand, the consumption of high carbohydrate-low protein diets increases the susceptibility for the development of metabolic disturbances in the longer-term. We have elaborated on some remaining issues, and propose that several new issues based on the findings discussed in the thesis need to be addressed in future research.

We should not consider this thesis as an isolated project, but as part of the Full4Health project (www.full4health.eu). The Full4Health project aims to further understanding of the mechanisms of hunger and satiety and how particular foodstuffs and nutrients affect them. It is based on the idea that if we are to make any progress in the battle against obesity and improve the quality of life, a new approach for body weight management is required. This includes re-establishing the normal homeostatic regulatory mechanisms by which lean individuals maintain the balance between long-term energy intake and energy expenditure. Within the 
Full4Health project, studies on the mechanisms of hunger and satiety are combined with intervention studies to validate the effects of the relevant food characteristics on the regulation of hunger and satiety. The added value of the project lies in the mass of expertise from a multidisciplinary team of experts from eight European countries. Academic labs and industry are both represented.

Nevertheless, we should ask the question; 'Does more scientific knowledge really help preventing and treating obesity?' Although the literature available on body weight management is growing, the number of people being overweight or obese is still increasing worldwide as well. How much more valuable would it be when we translate the academic wisdom into the larger societal context? I am convinced that I could and should contribute to this process by initiating actions and by intervening with existing initiatives. Therefore, the next sections describe how the key finding of this dissertation can have a societal impact that goes beyond scientific publications.

The first step is to spread awareness of the problem, both in terms of individual risk and social economic burden. In developed countries, people of all ages, sexes, and ethnicities are at risk, but they do not all realize this. Awareness need to be increased by publishing concrete data on the health consequences and medical costs of overweight and obesity, thereby facing people with their own behavior. In this way they could ask themselves the question whether they are at risk. The more they are convinced that they are at risk, the better they realize that they have to change their behavior in order to loose body weight, or to prevent gaining weight. Information on the health consequences and medical costs of overweight and obesity, and the substantial effects of prevention is available from national governmental institutions. Contacting these institutions and proposing that spreading of this information via national campaigns is necessary to reach a large number of people at risk helps emphasizing the problem of overweight and obesity. Information should be made accessible for a large number of people via newspapers, journals, flyers, and social media, thereby discussing different aspects of the problem.

Second, people should know that solutions for behavioral changes are available, and that they are capable to apply these changes. However, they have to set the goal of developing healthy habits, and they need to know how they could reach this goal. In general, health promotion requires the investment in a healthy life style, including more consumption of healthy foods and less consumption of 'nonhealthy' foods. Hereby we can rely on scientific knowledge from human nutrition research. Scientific publications describing results of such studies are usually published in scientific journals or reports. Full4Health will also establish and maintain a project website with an area containing content suitable for the nonspecialist reader.

Based on the findings of our studies and those of others, we propose to increase the relative proportion of protein in the diet for better body weight 
control. Remarkable effects on body weight loss were shown when relatively highprotein diets were consumed during energy restriction, which was partly ascribed to the satiating properties of proteins. Maintenance of energy expenditure may contribute to the beneficial effects of high-protein diets in energy balance, thus when consumed at a constant body weight. However, like spreading knowledge about the health consequences of overweight and obesity, information about healthy nutrition need to be spread among the public. This information should address questions such as: 'What is healthy eating behavior?', 'Which food products have a high protein content, and which are high in 'unhealthy' fats or sugars?', and 'Which amounts of these foods should be eaten?'. The familiarity of the public with healthy nutrition must not be overestimated. Therefore, it is useful to spread clear information about healthy nutrition, which is accessible for a broad public. To easily reach this broad public, we could use existing information channels. In the Netherlands, institutions that are important for the public opinion regarding healthy nutrition are the Voedingscentrum (Dietary Advice Centre) and Gemeentelijke Geneeskundige Diensten (Local Health Authorities). These institutions are accessible for researchers as well, so we could use this opportunity by planning phone calls. To increase the success rate, we need to plan the phone calls with ex-colleagues who are working in these institutions. We need to offer our help by translating the results and conclusions from our studies to keep these institutions up-to-date with the current knowledge on the topic. Subsequently, we need to offer our help to develop practical recommendations. We should keep in mind that these institutions probably have enough experts working on these topics. Then, it would at least be useful to stimulate the communication of existing recommendations regarding the consumption of higher-protein foods in daily life to people who are at risk for the development of overweight and obesity. We could provide physicians and dieticians with this information, and guide them in communicating this to their patients. Physicians and dieticians already use guidelines, but we need to stimulate the information supply from institutions such as the Voedingscentrum and Gemeentelijke Geneeskundige Diensten to keep the information up-to-date. These topics could be discussed during the phone calls with these institutions. Another possibility is to assist people to change behavior, because this is a difficult process. We can use several models for behavior modification that were developed based on scientific research. People using these models, for example psychologists, need to be contacted for instructions on how these models could be applied for developing healthy eating habits.

The next step is to consider the availability of healthy foods. In our opinion, the availability of high-protein foods, especially of high-protein snacks, which are easily accessible during the day, need to be improved. The food industry started working on the development of high-protein foods several decades ago. One of the challenges is to increase the protein content of food products without negatively affecting the taste. Some companies have several suitable products available, 
which are usually developed for specific target groups. For example, high-protein supplements are frequently used by sporters to stimulate the build-up of muscle mass. Recently, the consumption of high-protein foods has also been recommended in the elderly, because of decreases in protein synthesis, small increases in protein breakdown and a reduction in protein availability by age. As a result, several food companies have started working on the development and improvement of food products that could contribute to the reduction of functional decline in older adults. Furthermore, meal replacements that are used as a strategy to reduce body weight are usually high in protein. People who are willing to loose weight should be stimulated to use products of which the effectiveness has scientifically been proven. Although the brand names of products are usually mentioned in scientific articles, it is useful to communicate these to the broad public. To safe time and effort, it should be considered whether there is a need for the food industry develop new products, or whether existing products could be used by other target groups. Protein-rich supplements or liquids, which are specifically developed for sporters, older people or people who are dieting, could also to be consumed by a broad public. As an example, a high-protein shake could be consumed instead of milk during lunch. Furthermore, protein-rich puddings or soups, which are now used as high-protein diets, could be made commonly available. Another way is to promote the consumption of nuts as a 'healthy' snack, and to produce packages containing small portion sizes. Thus, like creating awareness of the problem of overweight and obesity, we should spread knowledge of the possible solutions mentioned above. The collaboration with partners from the food industry, within the Full4Health project, would accelerate the availability of protein-rich foods on the market. I cannot directly affect this process, but it may automatically result from stimulating the demand for these products through the processes mentioned above.

In short, understanding the mechanisms of hunger and satiety and how particular nutrients affect them is important for evidence-based interventions. More specific, unravelling the interaction of dietary protein with energy balance is warranted for the application of protein diets as successful preventive or treatment strategy for obesity. At this moment, it is my task to communicate the results of our studies to the scientific community by publications in peer-reviewed journals, and by presentations at conferences. Furthermore, I have to engage with the society by participating in public debate to spread knowledge about healthy nutrition, to improve the availability of high-protein foods, and to stimulate motivating people to incorporate these nutritional solutions in their daily life.

What is the impact if these actions are taken? It is possible to reach a large amount of people at risk by spreading knowledge about healthy nutrition, which includes high-protein foods. If no further actions are taken, the real impact may be limited. The largest effect may be expected from improving the availability of highprotein foods. This may even result in small improvements of healthy eating habits 
in people who are not able or willing to change eating behavior. Motivating and helping people in changing behavior would have an additional effect on improved healthy eating habits. Also, more people can take over the behavior. Of course, a $100 \%$ success rate should not be expected. But every step towards more healthy eating habits will result in a lower incidence and/or prevalence of obesity. Because the problem is large, at least some improvements can be expected if we take the steps that we are able to take. 


\section{REFERENCES}

1. World Health Organization. Obesity and overweight. Fact sheet $\mathrm{N}^{\circ} 311$. Version current March 2013. Internet: http://www.who.int/mediacentre/factsheets/fs311/en/ (assessed 13 May 2014).

2. World Health Organization. Controlling the global obesity epidemic. Version current December 2008. Internet: http://www.who.int/nutrition/topics/obesity/en (accessed 14 August 2014).

3. Polder J, Hoogenveen R, Luijben G, Van den Berg M, Boshuizen H, Slobbe L. Zorgkosten van ongezond gedrag en preventie. In: Schut FT and Varkevisser $M$, red. Een economisch gezonde gezondheidszorg. KVS Preadviezen. Den Haag: Koninklijke Vereniging voor de Staathuishoudkunde, Sdu Uitgevers, 2012:109-30. 
Dankwoord 
Promoveren is iets wat je niet alleen kunt. Inmiddels is mijn promotietraject afgerond en ligt hier een gedrukte versie van mijn proefschrift. Dit is een mooi moment om de mensen te bedanken die hieraan bijgedragen hebben.

Allereerst wil ik mijn promotoren bedanken. Margriet, bedankt voor uw begeleiding, de mogelijkheden en het vertrouwen dat $u$ mij gegeven heeft tijdens het doorlopen van mijn promotietraject. Het was fijn dat $u$ altijd meteen klaar stond voor vragen of feedback. De vele congressen en uitjes waren bijzonder om mee te maken. Verder zal ik nooit vergeten dat je niet altijd de kool en de geit moet sparen, en blij mag zijn als er weer een ei gelegd is. Rick Mattes, I have learned a lot from you! I have really appreciated your swift e-mail responses with feedback on two manuscripts, which has resulted in two publications.

I would like to thank the members of the reviewing committee; Prof. dr. Mensink, Prof. dr. Mercer, Prof. dr. Plat, Prof. dr. Raben and Prof. dr. Westerterp, for their time to review this thesis and for their presence during its defense.

Pilou, vriendinnetje. Zowel met werk als privé hebben we veel samen meegemaakt. New York en Seattle zal ik nooit vergeten. En onze 'Wie is de mol?' traditie houden we er zeker in! Bedankt voor al je steun en dat je mijn paranimf wilt zijn. Karianna, het was fijn dat we samen ons promotietraject konden doorlopen. Ik hoop dat ik niet te veel werkfrustraties eruit gegooid heb?! Jij mag vanuit je nieuwe baan de gezellige lunches met Dorit en Brenda voortzetten. En ik zal ook tijdens jouw promotie als paranimf aan je zijde staan.

Sofie, als onderzoeksassistent heb ik met veel plezier met je samengewerkt. Hierna zijn we samen aan het Full4Health project begonnen. Wat eerst een bijna onmogelijke studie leek te zijn hebben we toch maar tot een goed einde gebracht. Zo'n 90 maaltijden per dag bereiden konden wij natuurlijk niet alleen. Mandy, je bent een fantastische hulp en lieve collega geweest. Tijdens het werken in de keuken en met de proefpersonen hebben we dagelijks plezier gehad. Ik kijk ernaar uit om je op te komen zoeken in Exeter. Ook de rest van het team van hardwerkende assistenten was onmisbaar in de keuken! Yen, I thank you and your team for your contribution to the 'Beef Study' and the resulting publications.

Hanne, bij meerdere studies hebben we samen mogen werken. Hierdoor kon ik onverwachts zelfs wijzer worden over 'slaaponderzoek'. Mathijs, zonder jouw hulp als masterstagiaire was het respiratiekameronderzoek nooit zo vlot verlopen! Nuria, guapa! Gracias por toda su ayuda y amistad! Blandine, merci pour votre coopération. J'ai continué avec plaisir avec les mesures de MRI. You are always welcome to visit the Netherlands (Maastricht, Bemelen, Veluwe). Siti, when 
nobody else was available, you were always willing to help with the MRI measurements early in the morning. Thank you!

De andere (ex-)collega's van het cluster; Gill, Giulio, Guy, Mieke, Sanne, Stefan, Rick en Tanja. Het was een fijne tijd met jullie op het werk, maar ook daarbuiten bij activiteiten en congressen. En Dorien, bedankt voor het 'lieve collega' zijn! Tegen alle collega's van HB wil ik zeggen dat ik mede door jullie altijd met plezier ben komen werken.

Verder kan HB natuurlijk niet zonder een paar mensen. Jos, je bent gewoon onmisbaar! Loek, bedankt voor je behulpzaamheid en voor de krantenartikels die je voor mij bewaarde als ik weer eens een hardloopwedstrijd in Limburg had gelopen. Paul, ook jouw kennis kan niet ontbreken. Voor het analyseren van samples; Wendy en Hasibe, bedankt. En uiteraard de 'engeltjes' van het secretariaat. Ik sta nog steeds versteld van jullie kennis en optimisme. Geen van de vragen die ik in al die jaren bij jullie neergelegd heb is onbeantwoord gebleven.

De bijdrage van sommige mensen is niet direct terug te vinden in dit proefschrift. Toch is de steun van deze mensen voor mij onmisbaar geweest. Papa, mama, Marjolein en Florian; het is fijn dat jullie echt altijd voor mij klaar staan. Zelfs Maastricht is voor jullie nooit te ver! Vrienden, vriendinnen en familie, jullie helpen mij altijd weer verder. Niet alleen met goede gesprekken, maar ook met ontspanning, sport en gezelligheid. Bedankt voor alles wat jullie voor mij betekenen!

Uiteraard kan ik niet iedereen op deze manier persoonlijk bedanken. Maar ook de hulp van de mensen die hier niet met naam genoemd staan heb ik erg gewaardeerd. 
List of publications 


\section{PUBLICATIONS}

Martens EA, Gatta-Cherifi B, Gonnissen HK, Westerterp-Plantenga MS. The potential of a high-protein, low-carbohydrate diet top reserve intrahepatic triglyceride content in healthy humans. Accepted for publication PlosOne.

Martens EA, Tan S-Y, Mattes RD, Westerterp-Pantenga MS. No protein intake compensation for insufficient indispensable amino acid intake with a low-protein diet for 12 days. Nutr Metab 2014;11:38. doi: 10.1186/1743-7075-11-38.

Martens EA, Tan S-Y, Dunlop MV, Mattes RD, Westerterp-Plantenga MS. Protein leverage effects of beef protein on energy intake in humans. Am J Clin Nutr 2014;99:1397-1406.

Martens EA, Westerterp-Plantenga MS. Protein diets, body weight loss and weight maintenance. Curr Opin Clin Nutr Metab Care 2014;17:75-9.

Gonnissen HK, Mazuy C, Rutters F, Martens EA, Adam TC, Westerterp-Plantenga MS. Sleep architecture when sleeping at an unusual circadian time and associations with insulin sensitivity.

PLoS One 2013;8:e72877.

Janssens PL, Hursel R, Martens EA, Westerterp-Plantenga MS. Acute effects of capsaicin on energy expenditure and fat oxidation in negative energy balance. PLoS One 2013;8:e67786.

Hursel R, Gonnissen HK, Rutters F, Martens EA, Westerterp-Plantenga MS. Disadvantageous shift in energy balance is primarily expressed in high-quality sleepers after a decline in quality sleep because of disturbance. Am J Clin Nutr 2013;98:367-73.

Soenen S, Martens EA, Hochstenbach-Waelen A, Lemmens SG, Westerterp-Plantenga MS. Normal protein intake is required for body weight loss and weight maintenance, and elevated protein intake for additional preservation of resting energy expenditure and fat free mass. J Nutr 2013;143:591-6.

Martens EA, Lemmens SG, Westerterp-Plantenga MS. Protein leverage affects energy intake of highprotein diets in humans. Am J Clin Nutr 2013;97:86-93.

Gonnissen HK, Rutters F, Mazuy C, Martens EA, Adam TC, Westerterp-Plantenga MS. Effect of a phase advance and phase delay of the 24-h cycle on energy metabolism, appetite, and related hormones. Am J Clin Nutr 2012;96:689-97.

Gonnissen HK, Hursel R, Rutters F, Martens EA, Westerterp-Plantenga MS. Effects of sleep fragmentation on appetite and related hormone concentrations over $24 \mathrm{~h}$ in healthy men. $\mathrm{Br} \mathrm{J}$ Nutr 2012;8:1-9.

Martens EA, Lemmens SG, Adam TC, Westerterp-Plantenga MS. Sex differences in HPA axis activity in response to a meal. Physiol Behav 2012;106:272-7.

Rutters F, Gonnissen HK, Hursel R, Lemmens SG, Martens EA, Westerterp-Plantenga MS. Distinct associations between energy balance and the sleep characteristics slow wave sleep and rapid eye movement sleep. Int J Obes 2012;36:1346-52.

Lemmens SG, Martens EA, Born JM, Martens MJ, Westerterp-Plantenga MS. Lack of effect of highprotein vs. high-carbohydrate meal intake on stress-related mood and eating behavior. Nutr J 2011;10:136. 
Lemmens SG, Martens EA, Kester AD, Westerterp-Plantenga MS. Changes in gut hormone and glucose concentrations in relation to hunger and fullness. Am J Clin Nutr 2011;94:717-25.

Hursel R, Rutters F, Gonnissen HK, Martens EA, Westerterp-Plantenga MS. Effects of sleep fragmentation in healthy men on energy expenditure, substrate oxidation, physical activity, and exhaustion measured over $48 \mathrm{~h}$ in a respiratory chamber. Am J Clin Nutr 2011;94:804-8.

Lemmens SG, Born JM, Martens EA, Martens MJ, Westerterp-Plantenga MS. Influence of consumption of a high-protein vs. high-carbohydrate meal on the physiological cortisol and psychological mood response in men and women. PLoS One 2011;6:e16826.

Lemmens SG, Martens EA, Born JM, Martens MJ, Westerterp-Plantenga MS. Staggered meal consumption facilitates appetite control without affecting postprandial energy intake. J Nutr 2011;141:482-8.

\section{SUBMITTED MANUSCRIPTS}

Martens EA, Gonnissen HK, Gatta-Cherifi B, Janssens PL, Westerterp-Plantenga MS. Maintenance of energy expenditure on high-protein diets at a constant body weight may prevent a positive energy balance. Submitted

Martens EA, Lemmens SG, Veldhorst MA, Westerterp-Plantenga MS. Postprandial changes in appetite relate to postprandial changes in amino acid, GLP-1, ghrelin, and insulin concentrations after casein-, soy-, and whey-protein breakfasts. Submitted

Hursel R, Martens EA, Gonnissen HK, Hamer HM, Senden JM, van Loon LC, Westerterp-Plantenga MS. Prolonged adaptation to a low-protein diet does not lead to a more negative whole-body protein balance when compared with a high-protein diet. Submitted.

\section{PRESENTATIONS}

Martens EA, Tan SY, Mattes RD, Westerterp-Plantenga MS. No protein intake compensation for insufficient indispensable amino acid intake with a low-protein diet for 12 days. Congress of the Society for the Studies of Ingestive Behavior 2014; Seattle, United States. Poster presentation

Martens EA, Gonnissen HK, Gatta-Cherifi B, Westerterp-Plantenga MS. Maintenance of energy expenditure on high-protein diets at a constant body weight may prevent a positive energy balance. Project meeting 2014; Trondheim, Norway. Oral presentation

Martens EA, Tan SY, Mattes RD, Westerterp-Plantenga MS. No protein intake compensation for insufficient indispensable amino acid intake with a low-protein diet for 12 days. European Congress on Obesity 2014; Sofia, Bulgaria. Poster presentation

Gonnissen HK, Martens EA, Hursel R, Rutters F, Adam TC, Westerterp-Plantenga. Role of quality and timing of sleep in energy balance regulation. European Congress on Obesity 2014; Sofia, Bulgaria. Oral presentation

Martens EA. Effects of protein intake on the regulation of energy intake. Nederlandse Academie van Voedingswetenschappen (Dutch Academy of Food sciences) spring forum 2014; Wageningen, The Netherlands. Oral presentation 
Martens EA, Lemmens SG, Westerterp-Plantenga MS. Evidence for the protein leverage hypothesis? European Congress on Obesity 2013; Liverpool, UK. Oral presentation

Martens EA, Lemmens SG, Westerterp-Plantenga MS. No difference in protein leverage affecting energy intake between soy and whey protein. Experimental Biology 2013; Boston, US. Poster presentation

Martens EA, Lemmens SG, Westerterp-Plantenga MS. Protein leverage affects energy intake on highprotein diets in humans. Annual Nutrim symposium 2012; Maastricht, The Netherlands. Poster presentation

Martens EA, Lemmens SG, Hursel R, Westerterp-Plantenga MS. Dietary protein requirements and caloric over-consumption on unbalanced diets. Mid-term review Europees project 2012; Lille, France. Oral presentation

Martens EA, Lemmens SG, Westerterp-Plantenga MS. Evidence for the protein leverage hypothesis? NWO najaarsretraite werkgemeenschap voeding 2012; Deurne, The Netherlands. Oral presentation

Martens EA, Lemmens SG, Adam TC, Westerterp-Plantenga MS. Sex differences in HPA axis activity in response to a meal. Congress of the Society for the Studies of Ingestive Behavior 2012; Zürich, Switzerland. Poster presentation

Martens EA, Lemmens SG, Adam TC, Westerterp-Plantenga MS. Sex differences in HPA axis activity in response to a meal. European Congress on Obesity 2012; Lyon, France. Poster presentation 
Curriculum vitae 
Eveline Martens was born on July $26^{\text {th }} 1987$ in Rotterdam, the Netherlands. She completed secondary school at the Emmauscollege in Rotterdam in 2005. Consecutively, she started the bachelor General Health Sciences at the Maastricht University and obtained her bachelor's degree in 2008. During this bachelor program she followed 3 months of education on physical activity, health and ageing at the University of Jyväskylä, Finland. In 2009, Eveline graduated cum laude as master in Metabolism and Nutrition at the Maastricht University. In the same year, she started working as a research assistant in the Department of Human Biology at the Maastricht University. In December 2010, Eveline started her PhD research on dietary protein in relation to energy intake, energy expenditure and body composition under supervision of Prof. dr. Margriet Westerterp-Plantenga. She performed this human nutrition research as part of the European Full4Health project, and in cooperation with the industry. This work resulted in the present thesis titled 'Interaction of dietary protein with energy balance' and several publications in peer-reviewed journals. During her $\mathrm{PhD}$ trajectory, Eveline presented several abstracts at national and international conferences. In September 2014, Eveline worked as a nutritional scientist on a project for FrieslandCampina DMV. 
